\title{
MARKETING ŠKOLY
}

Ludvík Eger 


\section{MARKETING ŠKOLY}




\section{MARKETING ŠKOLY}

\section{Ludvík Eger}

https://doi.org/10.24132/ZCU.2021.04872

Plzeň 2021 


\section{MARKETING ŠKOLY}

Ludvík Eger

Recenzenti:

Prof. PaedDr. Mária Pisoňová, Ph.D.

Katedra pedagogiky, Pedagogická fakulta UKF v Nitre

Ing. Michal Mičík, Ph.D.

Katedra marketingu, obchodu a služeb, Fakulta ekonomická ZČU v Plzni

Grafický návrh obálky:

Tereza Kovářová

Typografická úprava:

Jakub Pokorný

Vydala:

Západočeská univerzita v Plzni, Univerzitní 2732/8, 30100 Plzeň

První vydání, 216 stran

Pořadové číslo: 2364, ediční číslo: 55-046-21

Plzeň 2021

ISBN 978-80-261-0487-2

ISBN 978-80-261-1044-6 (brožovaná vazba)

https://doi.org/10.24132/ZCU.2021.04872

(C) Západočeská univerzita v Plzni, 2021 doc. PaedDr. Ludvík Eger, CSc., 2021 


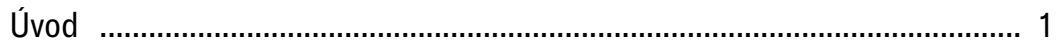

1 Studijní průvodce ............................................................................... 4

2 Pojem marketing a marketing školy ……........................................... 6

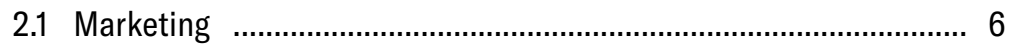

2.2 Marketing školy (vzdělávací instituce) ………............................... 8

2.3 Koncepce marketingu školy ............................................................ 9

2.4 Mýty a omyly ohledně marketingu školy …................................. 12

3 Marketingový mix a holistická koncepce marketingu ......................... 16

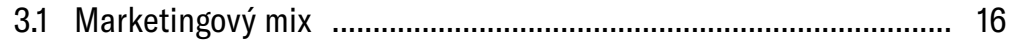

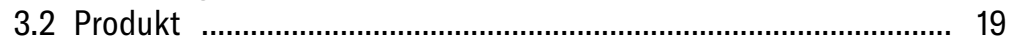

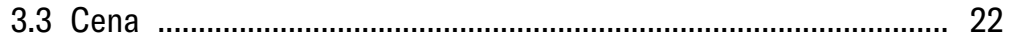

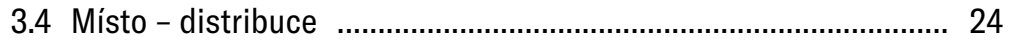

3.5 Marketingová komunikace ......................................................... 25

3.6 Základní vymezení nástrojů komunikačního mixu ........................ 28

3.7 Holistická koncepce marketingu .............................................. 35

4 Strategické plánování rozvoje školy .................................................. 39

4.1 Co je strategie organizace a strategické řizení? ......................... 41

4.2 Kličové oblasti strategického plánu školy .................................. 47

5 Poslání, vize školy a marketingový audit ......................................... 53

5.1 Poslání školy ....................................................................... 54

5.2 Formulace poslání školy ......................................................... 55

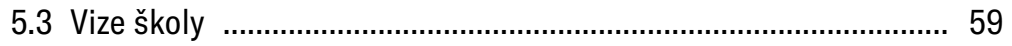

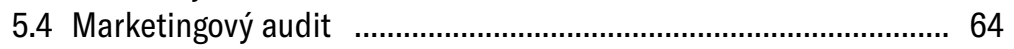

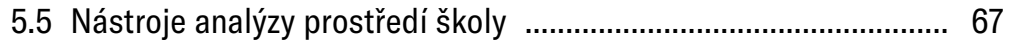

5.6 Možná struktura marketingového auditu školy ........................... 78

6 Kultura školy ............................................................................. 81

6.1 Koncept kultury organizace …………………......................... 82

6.2 Kultura školy a model kultury školy ......................................... 86

6.3 Kultura školy a klima školy ...................................................... 89

6.4 Jak je možné popsat kulturu školy? ........................................... 91

6.5 Silná a slabá kultura organizace …………….............................. 95

6.6 Změna kultury školy ................................................................ 98 


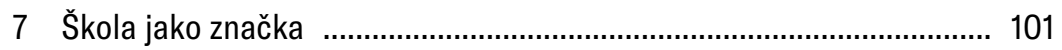

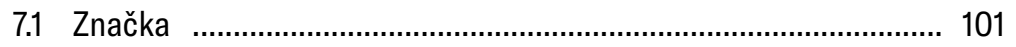

7.2 Hodnota značky f.................................................................. 105

7.3 Realizace positioningu a komunikace značky ........................... 109

8 Image školy ................................................................................... 114

8.1 Co rozumíme pod pojmem image školy? ................................... 115

8.2 Autoevaluace image školy ....................................................... 117

8.3 Vyhodnocení výsledků a príprava plánu pro image školy $\quad . . . . . . . . . .125$

9 Marketingová komunikace a komunikační kampaň ............................ 129

9.1 Realizace reklamní (komunikační) kampaně ............................. 130

9.2 Média a jejich využití v reklamní kampani .................................. 131

9.3 Plánování komunikační (reklamní) kampaně ............................ 135

10 Komunikace školy s veřejností na internetu ..................................... 146

10.1 Př́mý marketing a komunikace školy na internetu .................... 148

10.2 Strategie komunikace školy na internetu .............................. 149

10.3 Prezentace školy na internetu a www stránky školy ..................... 155

10.4 Komunity značek na sociálních médiích ................................. 163

11 Marketingový výzkum a škola ....................................................... 171

11.1 Zaměření marketingového výzkumu školy .............................. 172

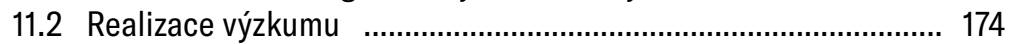

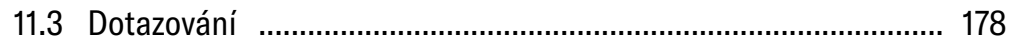

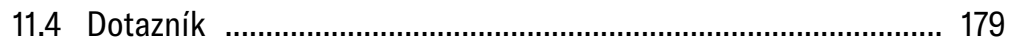

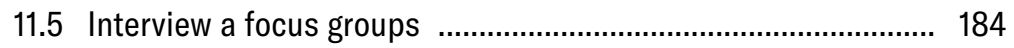

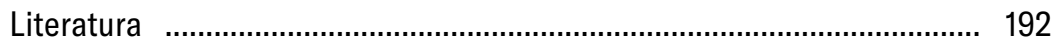

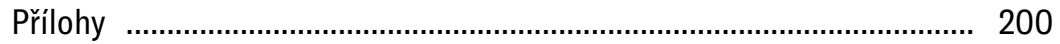

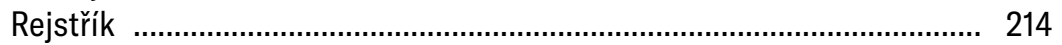




\section{POUŽITÉ ZKRATKY}

ATL

BCG

BTL

CZESHA

ČR

ČSÚ

ČŠI

EU

DDM

DVPP

EFE

ICT

IFE

KPI

MDA

MIS

MS̆

MŠMT

NiDV

NPI

OECD

OOH (reklama)

PEST analýza

PDCA

PPC (reklama)

PR

RVP

SCIO

SEO

SIMAR

SM

SMART above to line, nadlinková reklama

Boston Consulting Group, portfoliová matice

below to line, podlinková reklama

Unie školských asociací ČR

Česká republika

Český statistický úřad

Česká školní inspekce

Evropská unie

Dům dětí a mládeže

Dalši vzdělávání pedagogických pracovníků

External Factor Evaluation, navazuje na SWOT

Information and Communication Technologies, informační a komunikační technologie

Internal Factor Evaluation, navazuje na SWOT

Key Performance Indicator, kličcový ukazatel výkonu

Most Desired Action, nejvíce požadovaná akce

marketingový informační systém

mateřská škola

Ministerstvo školství, mládeže a tělovýchovy

Národní institut dalšího vzdělávání

Národní pedagogický institut

Organisation for Economic Co-operation and Development

Out of Home reklama, venkovní reklama

Political, Economic, Social and Technological analysis, analýza vnějšího prostředí

nástroj pro řizení změny, Plan-Do-Check-Act

Pay per Click, reklama s platbou za proklik

Public Relations

rámcový vzdělávací program

společnost zabývajíci se testováním, nyní má i sít ScioŠkol search engine optimization, optimalizace webu

Sdružení agentur pro výzkum trhu a veřejného mínění sociální média

mnemotechnická pomůcka pro formulování cílů 
SWOT analýza $\quad S=$ Strengths (Silné stránky), W = Weaknesses (Slabé stránky), $0=$ Opportunities (Přiležitosti), $T=$ Threats (Hrozby), analýza organizace

SŠ střední školy

ŠVP školní vzdělávaci program

TIMSS

Trends in International Mathematics and Science Study, mezinárodní šetření

TQM Total Quality Management, celkove rízení kvality

TTL Through to Line, koncepce reklamy spojujici ATL a BTL

UGT

URL Uses and Gratification Theory, teorie užití a uspokojení

USA

VIP Uniform Resource Locator, identifikace adresy na internetu United States of America, Spojené státy americké Very Important Person, velmi důležitá osoba

VRIO analýza analytická technika pro hodnocení zdrojů organizace i jejích konkurentů

VZ (školy) výroční zpráva

WOM

eWOM

Word of Mouth Marketing, ústní komunikace v rámci spotřebitelského chování

ZUŠ Základni umělecká škola

ZŠ základní škola 


\section{ÚVOD}

Předložená publikace vznikla s podporou projektu Fakulty ekonomické Západočeské univerzity v Plzni a slouží jako učebnice zejména pro aplikace marketingu pro studijní program Marketingové rízeni a pro další ekonomické studijní programy z oblasti Podnikové ekonomiky a managementu a Projektového managementu. Autor učebnice je na ZČU v Plzni také garantem a vyučujícím předmětu Školský management a publikace je určena i pro NMGr. studium na Pedagogické fakultě ZČU v Plzni jako jeden ze základních aktuálních zdrojů.

Je evidentní, že marketing školy je interdisciplinární záležitostí zejména mezi pedagogikou a marketingem. Profesor Průcha v publikaci Přehled PEDAGOGIKY (2006) pod disciplínou Ekonomie vzdělávání zařadil i podkapitolu Marketing školy, jež považoval za novou problematiku. Interdisciplinárnost ještě lépe ukazuje Pisoňová (2017) v publikaci zaměřené na management škol, kde ve schématu je skutečně na jedné straně pedagogika, na druhé straně management, ale v kruhu je doplňuji další společenské vědy jako například psychologie, sociologie, ekonomie, což je analogické i pro marketing školy. Ostatně z hlediska marketingu vycházíme ze světově uznávané publikace Kotlera a Kellera (2007 a 2013), jež má název Marketing management, a kde také najdete řadu př́kladů $z$ aplikací v oblasti marketingu služeb, neziskového sektoru a prímo i vzdělávání.

Vývoj sub-disciplíny marketing školy nebyl v ČR jednoduchý. Před rokem 1989 zde nebyl trh a pojem marketing se v podstatě nepoužival a předmět se nevyučoval. Řizením škol se okrajově zabývaly pedagogické fakulty a velkou výjimkou byl Ústav výzkumu a rozvoje školství UK v Praze. I v počátku 90. let proto převládalo tvrzení, že marketing a trh do školství nepatří. Je zajímavé poznamenat, že jsme si práli demokratickou společnost a tržní prostředí, „ale do školství ne“. Je možné poznamenat, že to částečně pramenilo i z nepochopení významu marketingu v neziskovém sektoru a v oblasti vzdělávání. Pravdou je, že i v západních zemích teprve v té době docházelo $\mathrm{k}$ jeho dynamickému rozvoji.

Za nastartování nového pojetí školského managementu považuji projekt pražského pracoviště Projekt rozvoje univerzitní př́ipravy řídicích pracovníků ve školství se zahraniční podporou, který nás díky lektorům z Anglie a Holandska 
a krátké stáži v obou zemích uvedl do problematiky z pohledu uvedených zemí (1996-1997). Experti z těchto zemí již v té době kladli velký důraz na hledání znaků kvalitních škol a využivání aplikací z managementu a marketingu pro jejich řizení v „moderním pojetí“. Bylo také zřejmé, že marketing znamená nejenom „to hledání vztahu instituce k trhu“, ale že jde především o komunikaci $s$ veřejností, vytváření spolupráce uvnitř i vně školy a o zaměření na klíčové hodnoty vzdělávání a škol atd.

Nicméně, je potřebné v tomto místě poznamenat, že trh v oblasti vzdělávání je specifický, je regulovaný a subjekty si zde nejenom konkurují, ale také na sebe navazuji a v řadě aktivit i spolupracují. Významným přínosem potom byla publikace Světlíka (1996) Marketing školy, kde je evidentní i zaměření na tržní orientaci zejména v segmentu středních a vysokých škol. Tato publikace také jasně ukázala, jak účelné je pro školy zabývat se marketingovými cíli, posláním, že je vhodné aplikovat SWOT analýzu atd.

$V$ následném období naše země začala směřovat do $E U$, která stojí na čtyřech základních svobodách, a to volném pohybu zboží, osob, služeb a kapitálu. Opět to bylo pro některé zástupce z oblasti školství jako něco vzdáleného, co se škol a vzdělávání netýká. Nicméně, na počátku 21. století, v globalizovaném světě a snad na konci celosvětové pandemie a předtím po celosvětové ekonomické krizi a při dynamickém nástupu digitální transformace, je jasné, že již nejenom lokální prostředí, ale i nadnárodní vlivy ovlivňují každou naši školu a vzdělávací proces v ní. Prostředí, ve kterém naše školy existují, a plní své nezastupitelné společenské role, se skutečně rychle mění.

\section{Základy marketingu školy vycházejí ze základní aplikace marketingu pro oblast služeb a specificky vzdělávacích služeb. Základní zaměření je na efektivní komunikaci s veřejností.}

Tak, jak rostl ve školském managementu zájem o kvalifikované řizení škol, bylo zřejmé, že aplikace marketingu jsou velmi vhodné pro strategické plánování rozvoje školy. Tomu byla věnovaná velká pozornost např́klad v Anglii (viz i Everard \& Morris, 1996, Fidler, 2000) a v ČR kromě zmíněné práce Světlíka (1996 a potom 2006 a 2009) aplikace rozpracovala v našem kurzu Jakubíková (2001) a nakonec jsme je prezentovali v publikaci Strategie rozvoje školy (Eger a kol., 2002). Téma se stalo velmi aktuálním při zavádění kutikulární reformy v ČR (viz i Eger, 2006). V posledních letech dochází opět ke snahám o inovace $v$ oblasti RVP a o orientaci škol na zvládání již výše zmíněných globálních vlivů a dynamických změn ve společnosti při plnění strategii EU, a i národních programů. Autor se účastnil jako expert i lektor projektu NiDV v Praze Strategické řízení a plánování ve školách a v územích (2016-2021) a kontakty s řadou vedoucích pracovníků škol v praxi, stejně jako podněty 
studentů na univerzitě, ale i náměty na inovaci marketingu školy ze zahraničí (viz DiMartiono \& Jessen, 2018; Lockhart, 2016a, b) jej vedly k napsání předložené inovované publikace $\mathrm{k}$ marketingu školy.

Kniha je psaná tak, aby podpořila současné aplikace marketingu v našich školách a vedla relevantní aktéry $\mathrm{k}$ implementaci nových přistupů a poznatků. Žáci či studenti, rodiče, zaměstnanci a dalši členové relevantních komunit ve vztahu ke škole jsou dnes v postavení zákazníků a klientů, kteři si vybírají, zda budou školu navštěvovat, pracovat v ni a podporovat ji (viz Lockhart, 2016a). Školy soutěži nejenom o žáky, ale i o kvalifikované učitele a dalši pracovníky a samožrejmě i o finanční zdroje. Marketing školy ve svém důrazu na marketingovou komunikaci včetně Public Relations mủže efektivně pomoci v tom, jak zákazníci / klienti škol budou vnímat vzdělávání a školství, a zda se na úrovni té dané instituce v regionu i do jejích aktivit zapojí.

Co najdete pro ČR nového v předložené publikaci? V marketingové komunikaci je to především téma komunikování školy jako značky. Získáte více informací a námětů k plánování, realizování a vyhodnocování komunikačních kampaní. Potom je to orientace na využití technologii v marketingu, tj. zde tím zejména myslíme www stránky škol a komunikaci prostřednictvím sociálních médií. Přidaná je i drobnějši kapitola k marketingovému výzkumu ve vztahu ke škole, protože bez vyhodnocení dat a vhodné práce se sekundárními i primárními zdroji, je obtižné připravovat a realizovat správná rozhodnutí. Jako červená nit se celou publikací prolíná zaměření na vhodnou komunikaci s cílovými skupinami školy prostřednictvím relevantních komunikačních kanálů. 


\section{STUDIJNÍ PRŮVODCE}

Předložená publikace použivá pro orientaci ve studiu následující orientační prvky, které vám pomohou v přehledu, $v$ motivaci ke studiu, $v$ opakování a využivání textu pro praktickou aplikaci. $V$ textu jsou též uvedeny náměty $z$ praxe, příklady či upozornění na kličové body a náměty k zamyšlení. Věříme, že uvedené grafické ikony vám pomohou při práci s textem.

Cíle kapitoly (najdete je v rámečku na počátku kapitoly)


Praktický př́klad nebo odkaz na nástroj vhodný k použití

? Otázky v textu a kontrolní otázky na konci kapitoly

[D] Doporučená dostupná základní literatura

Text publikace doplňují užitečné přilohy a rejstřík pro rychlejši vyhledávání kličových pojmů. 


\section{POJEM MARKETING A MARKETING ŠKOLY}

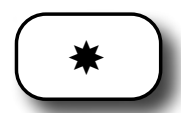

\section{Cíle:}

- Seznámit se s základním současným vymezením marketingu a pochopit specifika marketingu služeb.

- Diskutovat tržní pojetí a veřejnou službu v oblasti vzdělávání.

- Pochopit základy koncepce marketingu školy.

- Uvědomit si některé omyly a mýty ve vztahu k marketingovému řizení školy.

\&

marketing, koncepce marketingu školy, mýty o marketingu školy

8

Čas potřebný ke studiu základního textu kapitoly je

cca 10 minut + možnost rozšírení o studium externích zdrojů $z$ internetu.

\subsection{Marketing}

Pokud máme vymezit pojetí marketingu, použijeme $\mathrm{k}$ tomu tři následující definice a potom se zaměříme na specifika ve vztahu k marketingu služeb a ke školství v našem kontextu.

\section{$\square$}

Ve světově uznávané publikaci Marketing management Kotler a Keller (2013, s. 35) vycházejí z definice, která na marketing nahliží z pohledu celé společnosti: 
„Marketing je společenským procesem, jehož prostřednictvím jednotlivci a skupiny získávají, co potřebuji a chtěji cestou vytvárení, nabízení a volné směny výrobků a služeb s ostatními“.

Kotler a Keller (2013) zmiňují vymezení marketingu Americkou marketingovou asociací, která jej v roce 2017 dále aktualizovala a nově marketing vymezuje jako činnost, soubor instituci a procesů pro vytváření, komunikaci, poskytování a výměnu nabídek, které maji hodnotu pro zákazníky, klienty, partnery a společnost obecně (American Marketing Association, 2017).

\section{!}

Dalši definice zdůrazňuje roli zákazníka v marketingu a také naplňování cílů organizace (Světlík, 2018, s. 7) a uvádí následujíci: „Marketing je proces rízení, jehož výsledkem je poznání, předvídání, ovlivňování a v konečné fázi uspokojení potřeb a prání zákazníka efektivním a vhodným způsobem zajištujícím splnění cílù organizace“.

Také výstižnou definici prezentovala Jakubíková (2008, s. 40) a opět s akcentací zákazníka: „Marketing znamená uvědomělé, na trh orientované vedení firmy a organizace, kdy zákazník je do jisté míry alfou i omegou podnikatelského procesu."

$* * *$

Ačkoliv se uvedené definice liší ve své formulaci, významem se shodují v podstatné myšlence: vyzdvihují roli zákazníka v procesu marketingově orientovaného řizení a snahu o uspokojení nejen jeho potřeb a přání, ale i potřeb a cílů organizace. $V$ tomto smyslu se stává marketing stylem řizení, který je zákaznicky a tržně orientován. Významně orientuje činnost organizaci na vztahy se zákazníky, a to je také podstatné i pro soudobé aplikace marketingu v oblasti vzdělávání.

Právě díky marketingu si organizace a jejich managementy uvědomuji, že zákazníci (klienti) jsou klíčem k úspěchu organizace (včetně školy), a proto je nezbytné jim věnovat náležitou pozornost. Spokojení a loajální zákazníci a klienti se stali středobodem marketingového myšlení. Z tohoto důvodu by se měly organizace snažit vidět věci z pohledu zákazníka, pochopit jeho potřeby a najít rovnováhu mezi zájmy zákazníka a zájmy organizace. Kotler a Keller uvádějí, že dobrý marketing není o náhodě, ale o tom, jak pečlivě společnost plánuje, předvídá, provádí určité činnosti a o tom, jak využivá nejmodernější nástroje a techniky (Kotler, \& Keller, 2013). 
Marketing je více než jen aktivity, nastavené procesy komunikace či propagační materiály, je cestou, jak přemýšlíme o společnosti, škole i o nás, stavem mysli i postojem k řešení úkolů. Efektivní aplikace marketingu ve škole znamená, že vedení škol bude lépe komunikovat s rodiči, učiteli a dalšími zaměstnanci a partnery školy. Lépe bude získávat dodatečné zdroje pro školu, získávat podporu a budovat vztahy s veřejností (podle Lockart, 2016a).

Marketing se také neustále vyvijí a procházi řadou proměn. $K$ největším změnám došlo především na přelomu 20. a 21. století díky výrazným změnám v ekonomickém, politickém, technologickém i sociálním prostředí, včetně aktuálního důrazu na ekologický či zelený směr při specifickém akcentu na digitální technologie ve všech sférách společnosti.

\subsection{Marketing školy (vzdělávací instituce) ${ }^{1}$}

Před dvaceti lety byl v ČR marketing škol a dalších vzdělávacích zařízení úplně v plenkách. Čestnou výjimkou byla publikace Světlíka (1996) Marketing školy. Potom se k tématu objevily kapitoly v kolektivní monografii Efektivní školský management (Eger a kol., 1998) a následovalo několik skript pro kurzy školského managementu, jejichž obsah vyústil v inovované publikaci Strategie rozvoje školy (Eger, a kol., 2002). Opět Světlík (2006) vydal inovovanou publikaci Marketingové řizení školy a Eger (2006) několik kapitol k tématu v publikaci Řizení školy při zavádění školního vzdělávaciho programu.

V počátku byl dokonce marketing v oblasti školství řadou pedagogů odmítán s tím, že do školství „zanáši“ trh, později trpěl tím, že byly použivané jen jeho jednotlivé prvky bez holistického přístupu k němu (Kotler \& Keller, 2013) a bez snahy o jeho využití pro komunikování poslání a vizí našich škol, pro strategické plánování, ale i utváření zdravé a silné kultury škol, pozitivní image a budování potřebných vztahů s veřejností (Eger, a kol., 2002; Světlík, 2006). Teprve později došlo $k$ jeho vědomému využivání pro rozšíření potřebné komunikace škol s veřejností při zaměření na prezentaci hodnot a služeb, jež vzdělávací organizace poskytují. Na druhou stranu, praxe v ČR zejména kolem přelomu tisíciletí prínesla i příklady aplikace marketingu v někdy i velmi tvrdém boji vzdělávacích subjektů o žáky a studenty při snaze o prosazení se (zejména VŠ) nebo udržení se (zejména SŠ při „optimalizaci sítě“) na trhu vzdělávání, který, byt částečně regulovaný, zde skutečně je.

Ostatně Lubienski in DiMartino a Jessen (2018) s odkazem na dalši zdroje upozorňuje na to, že pokud žijeme v tržní společnosti, musí logicky trh ovlivňovat

${ }^{1} \mathrm{~V}$ publikaci budeme použivat pojem škola, ale budeme tím myslet různé vzdělávaci instituce. Nicméně, tato publikace je především zaměřena na marketing subjektů v tzv. regionálním školství, tedy zkratkami MŠ, ZŠ, SŠ... 
i oblast veřejného vzdělávání. Z toho také plyne, že s trhem skutečně přichází i vliv trhu na vzdělávání. Proto je i pochopení vývoje implementace a využití marketingu v oblasti vzdělávání klíčovou záležitostí. ${ }^{2}$

Dnes je naší hlavní úlohou objasnění výhod komplexního použivání marketingových přistupů pro podporu vzdělávacích služeb a jejich kvality, jež naše školy nabízejí a poskytuji, ale také musíme upozornit na jeho další vývoj a potřebu využití zejména nových př́stupů a technologii v komunikaci s veřejností $v$ současném světě.

\section{? Zvažte:}

- Můžeme odmítat působení trhu, když žijeme v tržní společnosti?

- Co znamená, že vzdělání ve společnosti souvisí v rozvinutých zemích se sociální a státní politikou pro postavení škol „na trhu“?

\subsection{Koncepce marketingu školy}

V souvislosti s výše uvedeným, není nezajímavé zmínit, že v roce 2020 v návaznosti na projekt SRP (NiDV, nyní NPI) Světlík připravil obsah kurzu Prezentace a marketing školy, který dále rozpracoval a lektoroval Eger v několika krajích ČR. Tím došlo nejenom $k$ další inovaci marketingu škol v ČR zařazením aktuálních témat např́klad ve vztahu k marketingu na internetu či budování dobrého jména školy jako značky, ale i k získání zpětné vazby z praxe zejména z MŠ a ZŠ.

Naše školy jsou součástí prostředí, ve kterém žijeme. Koncepce rozvoje společnosti se v oblasti vzdělávání odvijejí nejenom od historických hodnot, jež jsou spojené se vzděláním a věděním, ale jsou ovlivněné i globalizací našeho světa, koncepcemi Evropské unie, ale i národními strategiemi v oblasti vzdělávání, a nakonec i lokálními - regionálními zájmy.

Obecně můžeme souhlasit se Světlíkem (2009, s. 26), který uvádí, že u marketingu školy je potřebné rozlišovat krátkodobé a dlouhodobé potřeby a zájmy společnosti a krátkodobé i dlouhodobé potřeby a prání zákazníků školy. Školy by podle něj měly ve svých marketingových aktivitách brát v úvahu vyvažování tří důležitých faktorů:

- uspokojování potřeb zákazníků,

- prání zákazníků a

- veřejný zájem.

${ }^{2}$ Světlík (2018) má velmi pěkný název své základní učebnice marketingu: Marketing, cesta k trhu. 
Dnes v souvislosti s definováním marketingu kromě potřeb a prání zákazníků podtrhujeme jeho význam pro utváření a poskytováni hodnoty. Kotler (2003, s. 12) k tomu uvádí následujicí tvrzeni:

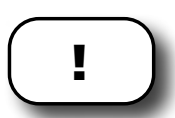

„Marketing je uměním a vědou o tom, jak vybírat cílové trhy a jak si prostrednictvím vytváření, komunikování a dodávání mimořádné hodnoty získat a udržet zákazníky a rozvíjet s nimi vztahy.“ $A$ právě pro oblast vzdělávání musíme podtrhnout jeho důraz na kvalitu služeb a jejich hodnotu (viz i korespondující požadavek na leadery v oblasti školství, Bush, 2008).

Ostatně dle Světlíka (2009, s. 26) potom „marketingová koncepce vychází z předpokladu, že škola, která chce $v$ tržním prostředí přežít a rozvijet se, by se měla zaměřit na žáka/studenta jako na svého klienta a vzájemný vztah chápat jako směnu hodnot mezi ní a studentem".

Toto vyloženě tržní pojetí je, dle našeho názoru, nutné korigovat. Ano, jsme v současné době svědky tvrdého boje škol a zejména soukromých vysokých škol o studenty nebo škol v regionech o přežití prì optimalizaci sítě, ke které dochází zejména v důsledku demografických vlivů a ekonomických tlaků na zefektivnění sitě škol. Ale na straně druhé si musíme uvědomit i úlohu vzdělání v socializaci a kultivaci lidí a povinnost státu zabezpečit př́stup ke vzdělání všem tam, kde je to dané legislativou, jež se odvijí od Listiny základních práv a svobod. Proto zdůrazňujeme, že se jedná o regulovaný trh a o službu, jež musí také příslušným vhodným způsobem společnost zabezpečit. Nemůžeme vzdělávání nechat jen „volnému trhu“. S tímto faktem přistupujeme i k marketingové koncepci škol.

Přehledně ji ve schématu zobrazil Světlík (2009, s. 26) a dále ji představíme a objasníme v původní verzi, která přehledně prezentuje jádro a důležité navazující okruhy.

Než tak ale učiníme, je potřebné si položit následující otázku:

\section{? Kdo všechno je zákazníkem či klientem škol?}

Určitě začnete jmenovat: žáci či studenti, rodiče, učitelé, ostatní pracovníci škol, nižši školy (jako partneři a dodavatelé) vyšši školy, podniky a další organizace pro které pripravujete absolventy (jako partneři a odběratelé). Patří 
sem ale také město, kde škola sídlí, region prezentovaný správou a samosprávou (včetně zřizovatele) ${ }^{3}$, ale i celá společnost reprezentovaná například MŠMT, ale též ČŠI. Naše školství již řadu let ovlivňuji strategie a koncepční materiály Evropské unie, která je také nadřazeným zájmovým subjektem, některé školy potom ještě více vnímají jako zákazníky i další subjekty z globalizovaného světa.

(ن)

Tento list můžete zkusit dále specifikovat a doplnit, určitě není vyčerpávající vzhledem $\mathrm{k}$ vaši konkrétní škole.

\section{Marketingová koncepce školy}

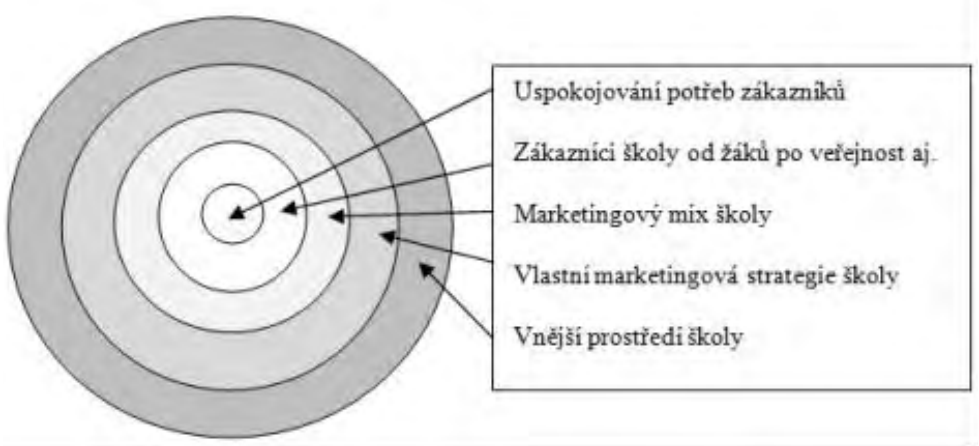

Obrázek 1: Schéma koncepce marketingu školy, dále viz Světlík (2009)

- Ve středu tohoto schématu stojí uspokojování potřeb „zákazníků“ či „klientů“ škol (viz obrázek 1). Jak jsme si uvedli výše, marketing se zaměřuje na potřeby a práni zákazníků a potenciálních zákazníků, to je kličové.

- Světlík (2009) staví nejbližší zákazníky do dalšiho kruhu kolem středu modelu. Řadí sem žáky / studenty, učitele a ostatní pracovníky a pod pojmem lidé to budou nejenom rodiče, ale všichni dalši lidé, kteři jsou skutečně s naší školou v těsném či blízkém vztahu.

- Hned navazuje kruhem, který obsahuje základní marketingový mix s produktem, cenou, distribucí a komunikaci (protože jsme v marketingu

\footnotetext{
${ }^{3} \mathrm{U}$ soukromých škol roli zřizovatele hraje vlastník a najdeme v praxi řadu variant.
} 
služeb, tak by bylo možné i tento kruh rozšiřit o další marketingová „P“, zde zejména o People) ${ }^{4}$.

- V navazujícím kruhu je potom uvedeno zacílení, diferenciace, komunikační strategie a budování značky školy, jež spolu s image školy považujeme za významná témata marketingu školy.

- V nejširším vnějším kruhu jsou potom uvedeny složky prostředí od mezoprostředi $i^{5} \mathrm{k}$ makroprostředí. Přitom do mezoprostředí zahrneme jak dodavatele (pro ZŠ je to u žáků MŠ a rodiny), tak i odběratele (pro ZŠ jsou to u žáků střední školy), ale i konkurenci (dalši ZŠ se svými vzdělávacími programy v obci). Do makroprostředí patří složky tzv. PEST analýzy, tj. politické, ekonomické, sociální a technologické prostředí (přidávají se i další, např̀. ekologické aj.).

Tím je skutečně jen stručně, ale přehledně, objasněn přistup ke koncepci marketingu školy, který od svého středu = uspokojování potřeb prostřednictvím poskytovaných hodnot, přes orientaci na zákazníky školy a udržování komunikace a vztahu s nimi vede $k$ vlastní marketingové strategii, jež se opírá o práci s tzv. marketingovým mixem a bere v úvahu i působení vnějšího prostředí školy.

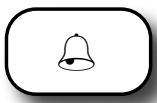

Pokud budeme diskutovat o současných trendech $\mathrm{v}$ oblasti marketingu školy, tak je to při zdůrazňování marketingové komunikace a budování dobrých vztahů se všemi zainteresovanými cílovými skupinami, vyžívání nových médií a orientace na budování dobrého jména školy s prezentací školy jako značky (viz i Eger in Pisoňová a kol, 2014; Lockhart, 2016a; DiMartino \& Jessen, 2018).

\subsection{Mýty a omyly ohledně marketingu školy}

Jako námět do diskuse dáváme uvedení omylů ohledně marketingu školy tak, jak je ve své publikaci uvedl Světlík (2009) nebo je diskutuje Lockhart (2016a) nebo se $s$ nimi setkáváme $v$ praxi. Mnohé plynou logicky $z$ toho důvodu, že marketing není součásti výuky na pedagogických fakultách a není součástí základního obsahu práce pedagogického pracovníka tak, jak je původně pojímán.

\footnotetext{
${ }^{4}$ Tzv. marketingový mix, a především koncept integrované marketingové komunikace si objasnime dále v publikaci.

${ }^{5}$ Dnes se použivá ve stejném významu mikro a mezoprostředí.
} 
- Marketing není vlastně nic jiného než reklama a propagace školy.

- Marketing je zaměřen pouze na cílové skupiny mimo školu.

- Marketing se nás netýká, my jsme učitelé a marketingové řizení školy je víceméně problémem vedení školy, a ne řadových pedagogických pracovníků.

- Prání a potřeby žáků a studentů či rodičů jsou shodnými pojmy.

- Při inovaci vzdělávání (produktu) v naší škole vycházíme z legislativy a pedagogických dokumentů, není potřebné komunikovat se zástupci tzv. cílových skupin.

- Z Z tohoto pohledu je zřejmé, že i strategie rozvoje školy je jen záležitostí managementu školy a připadně sboru školy.

- S Širší okoli školy nemá na naši školu a vzdělávání v ní zas tak důležitý vliv.

- Dobře víme, jak komunikovat s lidmi z okoli školy, není potřebné se jich ptát na jejich názor.

Teprve při uvědomění si, že každý pedagogický pracovník musí komunikovat se zástupci různých výše uvedených cílových skupin, že se dnes podílí nejenom na realizaci RVP/ŠVP = hlavního produktu (vzdělávací služby), ale i na strategii školy, utváření její kultury, budování jeji image atd., najednou vidíme, že je účelné aplikovat marketing a že se to zejména v koncepci integrovaného marketingu týká skutečně nás všech. I proto je vhodné věnovat pozornost předložené publikaci a využit poznatky z marketingu v podstatě pro všechny důležité aktéry ve škole i mimo ni.

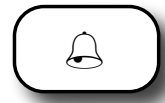

Námět ke zvážení:

Jako rozšiřujíci text uvedeme poznámku k vývoji marketingových koncepcí obecně. Je zajímavé sledovat, jak minimálně prvky některých původních koncepcí stále nacházíme i na současném vzdělávacím trhu:

- Výrobní koncepce - zákazníci (spotřebitelé) budou mít v oblibě ty produkty, které jsou široce dostupné za nízkou cenu.

- Výrobková koncepce - vychází z přesvědčení, že zákazníci si oblíbí především ty produkty, které nabízejí vyšší kvalitu (obvykle je to spojeno s vyšší cenou). 
- Prodejní koncepce - staví na předpokladu, že bez až agresivní prodejní a propagační činnosti si zákazníci málo koupí.

- Marketingová koncepce - klič $\mathrm{k}$ dosažení cílů organizace spočíá $v$ tom, že bude uspokojovat potřeby zákazníků, a to na požadované úrovni účinněji a efektivněji než konkurence.

Doplňte si sami příklady ze školské praxe, které se dají vhodně přiřadit $k$ jednotlivým koncepcím. Zaměřte se napřiklad na projevy propagační činnosti, které se týkaji školských subjektů a jejich vzdělávacích programů nebo doplňkových služeb, ale na druhé straně třeba na př́klady reklamy, které se týkaji vybavení pro školy, učebnic, dalších pomůcek atd.

$V$ současné době se $v$ marketingu vychází z tzv. holistické marketingové koncepce (Kotler \& Keller, 2013), která reaguje na změny v současném globalizovaném světě a staví na komplexnosti marketingových aktivit s tím, že uspokojování potřeb a prání zákazníků je na prvním místě. Při orientaci na spokojené a loajální zákazníky záleží na propojení všech procesů a aktivit v organizaci. Koncepci si podrobněji objasníme v další kapitole.

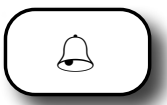

Zvažte:

Současné prostředí pro všechny typy škol je mnohem konkurenčnější, než tomu bylo dřive. Školy soutěži nejenom o žáky či studenty, ale také o učitele, dalši administrativní a provozní zaměstnance a samožrejmě také o podporu komunity. Studenti (žáci), rodiče, zaměstnanci a členové komunity jsou nyní „zákazníci“, kteři mohou volit, zda budou navštěvovat školu, pracovat v ní, či ji podporovat, nebo také ne. Jejich volba je ovlivněna tím, jak obecně vnímaji úlohu (hodnotu) vzdělání a jak i „vidi“ konkrétní školu v regionu (volně přeloženo dle Lockhart, 2016b). Růst tohoto konkurenčního prostředí vždy u nás podtrhoval i Světlík (1996, 2009), ale ne vždy tomu zástupci pedagogické veřejnosti chtěli, a dokonce i dnes chtějí, věřit.

Kapitolu uzavřeme tím, že pro úspěch v marketingu školy Lockhart (2016b) vyzdvihuje zejména tyto součásti: Public Relations, vztahy s médii, vztahový management a marketing a komunikaci. My zdůrazníme, že to celé platí v rámci integrované marketingové komunikace. 


\section{? Kontrolní otázky a úkoly:}

- Definujte svými slovy marketing.

- Dokážete objasnit schéma marketingové koncepce školy?

- Vytvořte si seznam nejdůležitějších cílových skupin z pohledu vaší školy a stručně sepište jejich potřeby a možná práni ve vztahu ke škole.

- Co je současným trendem v marketingu školy?

- Podívejte se na seznam omylů ve vztahu k marketingu školy. Se kterým jste se setkal-a?

\section{[DD Literatura:}

Kotler, P., \& Keller, K. L. (2013). Marketing management. Praha: Grada.

Světlík, J. (2009). Marketingové rízení školy. Praha: Wolters Kluwer.

Světlík, J. (2018). Marketing, cesta k trhu. Praha: VŠPP a.s. Dostupné z: http:// www.marketingsvetlik.cz/

Pisoňová, M. a kol. (2014). Školský manažment pre študijné obory učitelstva a pripravu vedúcich pedagogických zamestnancov. Bratislava: Univerzita Komenského v Bratislave. Dostupné z: https://www.fedu.uniba.sk/filead$\mathrm{min} /$ pdf/Sucasti/Katedry/KP/KAPESO/Skolsky_manazment.pdf 


\section{MARKETINGOVÝ MIX A HOLIS- TICKÁ KONCEPCE MARKETINGU}

\section{紧}

\section{Cíle:}

- Umět vymezit úkoly základních nástrojů marketingového mixu.

- Pochopit rozdíl pohledu organizace $(\mathrm{P})$ a zákazníků $(\mathrm{C})$ na marketingový mix.

- Diskutovat př́klady v aplikaci nástrojů mixu pro marketing školy.

- Pochopit základy koncepce marketingu školy.

- Uvědomit si některé omyly a mýty ve vztahu k marketingovému řizení školy.

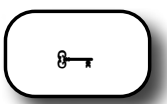

\section{Klíčová slova:}

marketingový mix, produkt, cena, distribuce, marketingová komunikace, lidé, holistická koncepce marketingu

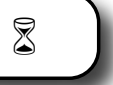

Čas potřebný ke studiu základního textu kapitoly je cca 15 minut + možnost rozšírení o studium externích zdrojů $z$ internetu.

\subsection{Marketingový mix}

\section{$\square$}

Marketingový mix představuje: „soubor taktických marketingových nástrojü, které firma používá $k$ úpravě nabídky podle cílových trhů. Marketingový mix zahrnuje vše, co firma může udělat, aby ovlivnila poptávku po svém produktu.“ (Kotler, 2007, s. 70) 
Světlík (2016) využívání nástrojů marketingového mixu trefně spojuje s realizací strategie organizace, s budováním značky a s vyvijením aktivit organizace, které vedou k uspokojování a ovlivnění potřeb a přání zákazníků.

\section{Marketingový mix tedy představuje soubor nástrojů, jejichž pomocí utváŕíme vlastnosti vzdělávacích služeb, které nabízíme zákazníkům.} Za klasické prvky marketingového mixu jsou považovány čtyři „P“: Product, Price, Place, Promotion. Pro marketing služeb je základní mix rozšiřován např. o důležitý prvek People (a samozřejmě je to velmi významné pro oblast vzdělávání, viz i napřiklad Lockhart, 2016a, nebo Světlík, 2009), ale dle pojetí různých autorů existuji i dalši rozšiřujicí „P“.6

$\mathrm{K}$ základním „4P“ řada autorů dále přidává „přímý marketing“ (direct marketing), který je orientován na využívání přímých kanálů k dosažení zákazníků a doručení služeb bez potřeby marketingových prostředníků (dle Kotler \& Keller, 2013).

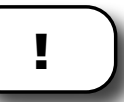

Pro marketéry je také důležité se na základní marketingové „P“ dívat z pohledu zákazníka (tzv. „C“). Obojí stručně objasníme:

- Produkt (Product) se nám mění v řešení pro zákazníka, respektive zvažujeme, jakou hodnotu zákazník hledá a jak uspokojí jeho potřeby (Customer Solution). Př́klad: jakou hodnotu a pro jaké žáky a rodiče má nabídka doučování z předmětu...? Pro koho je velmi hodnotná rozšířená výuka angličtiny?

- Cena (Price) se nám mění v celkové náklady pro zákazníka (Customer Cost). Nejenom penězi platí zákazník. Zvažte kolik času jej stojí dojiždění / doprava žáka do školy? Jaké dalši obtiže (náklady) musí překonat např́klad rodič při komunikaci se školou? A kolik napřiklad rodiny stojí základní ICT vybavení pro distanční výuku?

- Místo a distribuce (Place) se mění na pohodlí z pohledu zákazníka (Convenience). Co je pro něj pohodlnější? Jak asi oceňuji studenti váš e-learning či konzultace s využitím ICT? Jak je možné zlepšit dostupnost naši služby pro...? Také, jak pohodlně získaji rodiče informace o škole a o výstupech vzdělávání svých dětí?

- Marketingová komunikace (Promotion) se mění v požadavek obousměrné a efektivní komunikace zákazníka s poskytovatelem

\footnotetext{
${ }^{6}$ Někteři autoři použivaji dalši rozšiření napřiklad o materiálním prostředí nebo procesy (Vaštíková, 2014; Zamazalová, 2009).
} 
vzdělávací služby (Communication). Jak mohou komunikovat studenti či rodiče žáků s vaší školou? Které komunikační kanály (klasické versus spojené s ICT) mohou využit?

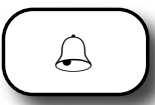

Zvažte:

Velké změny z pohledu aplikace „4P“ i „4C“ nám přinese tzv. digitální transformace, která pomalu, ale jistě dopadá i na naše školství. Ostatně je zřejmé, že pandemie COVID-19 řadu věcí v této oblasti urychlila. 0 co se bude jednat naznačuji studie jako např. World Economic Forum (2020) a jiné. Nicméně, zvažte, že digitální transformace je dnes více o rozvoji, a tedy i vzdělávání lidí, než o technologiích (např. Frankiewicz, 2020; Sundblad, 2020).

$* * *$

Jakubíková (2008) pro podnikatelskou sféru uvádí, že tradiční marketingová koncepce založená pouze na „4P“ již za nových podmínek na trhu a ve společnosti není dostatečně účinným nástrojem $\mathrm{k}$ ovládnutí trhu. Je potřebné pracovat i s jinými podobami marketingového mixu, zejména „4C“. Platí to i pro neziskový sektor, tzn. i pro školy, viz dále.

Pro lepší objasnění si můžeme základní vztahy ukázat v upraveném schématu (obrázek 2) dle Kotler a Keller (2013) pro školu:

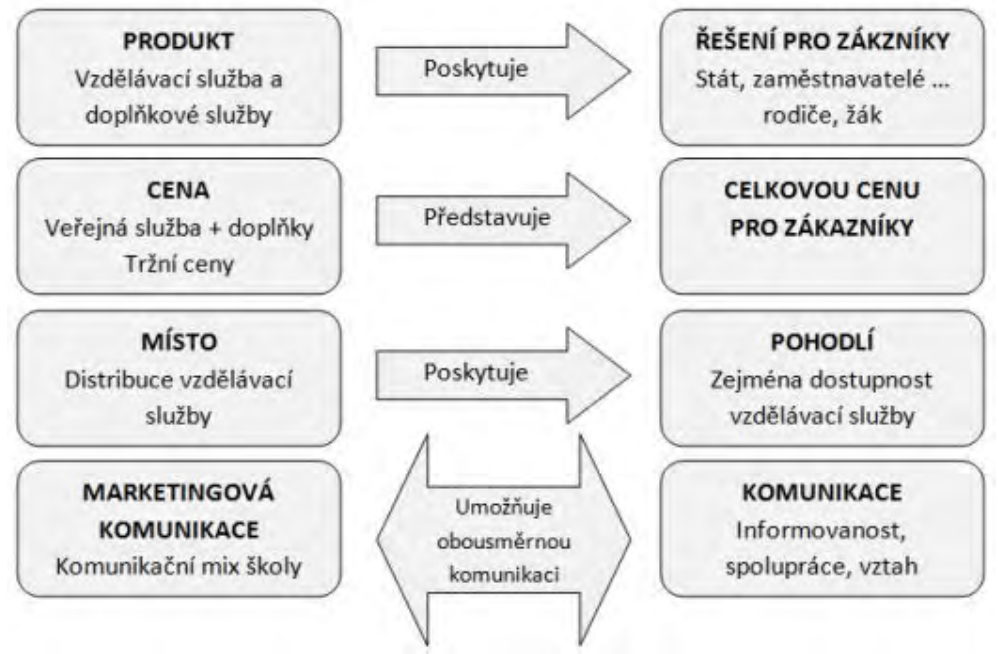

Obrázek 2: Vztah 4 P a 4 C v marketingu školy 


\subsection{Produkt}

\section{$\square$}

„Produkt je souhrn objektů či procesů, které přinášejí zákazníkům určitou hodnotu, zboží a služby jsou dílčí kategorie, které představují dva typy produktu.“ (Kotle, \& Keller, 2013)

Uvedení autoři objasňují, že „marketéři dnes pracují s deseti základními typy objektů: zbožím, službami, událostmi, zážitky, osobami, místy, vlastnickými právy, organizacemi, informacemi a myšlenkami“ (Kotler \& Keller, 2013, s. 35). Všechny uvedené objekty se týkají i oblasti vzdělávání. Zvažme: učebnice, vzdělávaci programy a kurzy, výročí školy, den otevřených dveří, exkurze, diskuse s významnou osobou, návštěva památného místa, spolupracujicího podniku, autorská práva k vzdělávacím objektům, škola je členem..., poskytujeme aktuální informace $0 . . .$, prosazujeme myšlenky inkluze či zdravé školy aj.

\section{!}

Obecně můžeme uvést, že produkt má své jádro (např. je tvořeno profilem absolventa vzdělávacího programu), potom vlastní skutečný produkt (vzdělávací program, kurikulum kurzu v širším pojetí) a nakonec rozšírený produkt (doplňkové služby, ale i benefit získaný pozitivním klimatem podporujícím všechny aktivní studenty).

\section{!}

Protože naším hlavním produktem je vzdělávaci služba, musíme z pohledu marketingu zvažovat i tzv. specifika služeb:

a. Nehmotnost - služby (také vzdělávací program) se nemohou vážit, měřit, nelze se jich dotýkat a zákazník si je nemůže předem vyzkoušet.

Školní vzdělávací program je slib, že jeho prostřednictvím žák absolvuje školu a získá požadované kompetence dle standardu pro.., také že vzdělávání proběhne bezpečně s kvalifikovanými učiteli atd. atd.

Při zhmotnění služeb je důležitá marketingová komunikace, ve které se snažíme zdůraznit přednosti a výhody, které nákupem vzdělávací služby může klient získat. $V$ marketingu zde také využiváme tzv. nepřímé indicie nebo 
také signály kvality (lokalizace školy, vzhled a vnitřní úprava budovy, kvalitní učitelé apod., image...).

Zhmotněni vzdělávací služby je realizováno např. i studijními materiály školy, informačním letákem apod. Možnost vyzkoušení je někdy realizována dnem otevřených dveři a podobnými akcemi (př. návštěva první třídy dětmi z MŠ).

b. Pomíjivost - služba je neskladovatelná, pokud se žák či student určité výuky nezúčastní, nelze tu samou službu obdržet znovu. Obecně se uvádí, že pomíjivost služby není problémem, je-li poptávka stálá, což obecně pro školství platí (ne tolik pro specifické placené vzdělávací služby, kroužky aj.).

Pomíjivost služby můžeme částečně odstranit použitím techniky či technologie, např. záznamem přednášky, vytvořením pomůcky pro domácí či individuální studium prostřednictvím např. e-learningu. ${ }^{7}$ Nebo sem mǔžeme zahrnout pomoc žákům doučováním či individuálním studijním plánem a tím eliminovat např́iklad jejich neúčast na vyučování z důvodu nemoci atd.

Do této oblasti ovšem patři i problém synchronizace služeb, tzn. vyrovnání sezónnosti v poptávce a nabídce (důležité je to zejména pro soukromé školy či různá vzdělávací centra). Zde potom využiváme různé nástroje marketingového mixu.

c. Neoddělitelnost - zde od osoby poskytovatele, učitele i celé školy ve smyslu jejího sboru a ostatních pracovníků včetně klima školy.

Služby jsou poskytované prímo nebo zprostředkovaně lidmi. Ti mají určitou pracovní kapacitu, kvalifikaci, osobní vlastnosti atd. Z tohoto hlediska je logicky kvalita služeb proměnlivá a úkolem je zde zajištění jeji kvality. Ve vzdělávání je nesmírně důležitá interakce učitelů a žáků (a to dokonce i v distanční výuce). Lidé z organizace jsou v interakci s „klienty a zákazníky“. Navíc, součástí vzdělávacího procesu a života ve škole jsou další lidé, žáci... Úkolem je mít kvalitní učitele a koordinovat kooperaci lidí realizujících službu a dbát o dobré klima ve škole.

d. Heterogenita (proměnlivost) - malá míra standardizace.

Řešení souvisí s předešlým, tj. kvalita poskytované služby - vzdělávání je závislá na tom, kým je tato služba poskytována. Navíc platí, že ta samá vzdělávací hodina může mít různé výstupy při podání různými učiteli (plus

\footnotetext{
${ }^{7}$ Nicméně, COVID-19 nám také ukázal problém, kdy na jedné straně byla vybavená škola pro klasickou výuku, ale my jsme většinu jejiho vybaveni nemohli použit. Řešili jsme, jak to nahradit, jak vytižit kapacity?

Pro školství je spíše typické řešení problému, že pokud výuka proběhne a žák se ji nemohl účastnit, jak mu ji dokážeme nahradit? Z pohledu pedagogiky, to znamená, že dokážeme podpořit, aby zameškané dohnal (také např́klad individuálním studijním plánem apod.).
} 
odlišnosti jsou i v paralelní výuce atd.). Ve školách se to také snažíme řešit standardy jako je rámcový vzdělávací program, akreditační dokumenty, ale také s realizací vnitřních předpisů a pokynů vztahujících se ke vzdělávacímu procesu, rozvojem a DVPP učitelů atd. Standardizace a kontrola podporují dosahování kvality služeb.

e. Vlastnictví - službu nelze vlastnit, žák - student, zákazník k ní má pouze prístup.

Službu nelze vlastnit, tj. školu, třídu a ani učitele nemohou žáci a jejich rodiče vlastnit, ale mohou k nim, a k poskytovanému vzdělávacímu programu, získat přistup. Marketing zde musí obecně zdůrazňovat výhody plynoucí z nevlastnění produktu, ovšem u škol je to poměrně evidentní záležitost. Zde i v oblasti školství přecházíme $\mathbf{v}$ marketingu $\mathbf{k}$ budování silných značek, které jsou pozitivně zapsané v myslích svých klientů a ovlivňují i potenciální klienty.

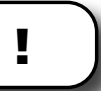

Produkty, a stejně tak i vzdělávací programy, mají své životní cykly.

Produkty v oblasti vzdělávání je také možné členit do různých kategorií.

- Základní produkty v oblasti vzdělávání (studijní programy, kurzy, školení...).

- Produkty spojené s osobností (přednáška experta, učebnice autorů, setkání s absolventy...).

- Myšlenkové produkty (strategie rozvoje vzdělávací soustavy, vzdělávací informace v médiích, vzdělávací objekt...).

- Produkty z oblasti podmínek vzdělávání (legislativní opatření, doprava na exkurzi, výlet, vložné na konferenci s materiály, tisk..., software pro...).

- Klasické materiální produkty (vybavení tříd, učební pomůcky...).

Naznačené členění je možné doplnit a některé dílči položky logicky zasahují i do více kategorií. Smyslem je ukázat, že se „nejedná jen o vlastní vzdělávací proces".

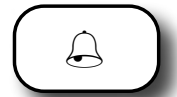

Námět ke zvážení:

Jako poslední stručnou poznámku k produktu uvedeme, že i pro školy je stále důležitější představovat svůj produkt (školní vzdělávací program / obor 
studia) jako značku. Tu představuji názvy, termíny, znaky, symboly, designy nebo libovolné kombinace těchto prvků, určené $k$ identifikaci produktu určité školy a jeho odlišení od produktu konkurence (upraveno dle Kotler \& Keller, 2013). Úlohou celého marketingu je péče o jeji hodnotu.

Pro zákazníka je hodnotné to, co je pro něj užitečné (naplňuje to jeho potřeby a prání), prípadně mu to přináší nějaké úspory proti např. realizaci podobné vzdělávací služby u konkurence, ale také třeba dobrý pocit či splněné prání nebo společenské uznání obvykle spojené s vlastnictvím značky (maturita na..., diplom...).

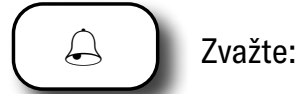

Poskytování kvalitního produktu, v našem případě vzdělávací služby, je nejdůležitějším elementem pro dosažení marketingového úspěchu. Bez spojení s tím, že poskytujete kvalitní produkt či službu, stane se jakýkoliv úspěch v marketingu nejenom obtižným, ale až neuskutečnitelným (podle Lockhart, 2016a).

\subsection{Cena}

\section{$\square$}

Cena je důležitým prvkem marketingového mixu a dotváŕí charakter produktu. Je také jediným prvkem mixu, který tvoři príijmy organizace. Samozřejmě je zřejmé, že je zde velký rozdíl u služeb, které jako veřejné vzdělání zabezpečuje společnost a u služeb, které jsou organizované jako podnikání za účelem zisku.

$\mathrm{K}$ tomu je potřebné dodat, že i veřejnou službu platíme. Platíme ji ze svých daní, a proto by měla podléhat náležité kontrole na straně jedné a na straně druhé jsou zde ovšem zájmy společnosti, kde je naopak potřebné si uvědomit, že kvalitní vzdělání jako součást potřebného rozvoje lidských zdrojů, není levné a vyžaduje investovat značné prostředky.

\section{!}

Pozor na to, že z marketingového hlediska nejsou cenou jen „prímé náklady“. Z pohledu zákazníka je potřebné zvažovat celkové náklady, včetně 
doplňkových služeb, ale i ztráty času a obětování jiných přiležitostí (např. $v$ trávení volného času) atd.

- Jak vysoká je cena za to, že žák navštěvoval 9 let právě vaši ZŠ?

- Zvažte, jakou cenu (nejde jen o peníze) platí rodiče během roku v souvislosti s tím, že jejich syn či dcera se vzdělává právě ve vaší škole?

U privátních vzdělávacích organizací se potom cena tvoři podobně jako v oblasti podnikání. Vychází se z marketingové politiky firmy. Přihliží se $k$ produktu či baličku služeb (také $k$ jeho kvalitě a výjimečnosti), $k$ distribuci, $k$ marketingové komunikaci včetně image programu nebo školy, $k$ lidem, a to jak ke kvalitě např. přednášejícího experta, tak ke kvalitě zákazníků. Vliv může mít i požadavek na komplexnost, ale i certifikaci služeb atd. ${ }^{8}$

Stanovení ceny může vycházet z klasických přistupů a jejich kombinace: nákladová cena, porovnávání se s konkurencí, orientace na zákazníka (jakou hodnotu pro něho nabizený produkt představuje, a to i ve vztahu $\mathrm{k}$ nabídce na trhu?).

\section{$\sqrt{ }$}

Hodnocení vzdělávací služby je potom porovnáváním kvality vzdělávacího výstupu a výše celkové ceny. Světlík (2009) to zobrazuje následujícím vzorcem (obr. 3):

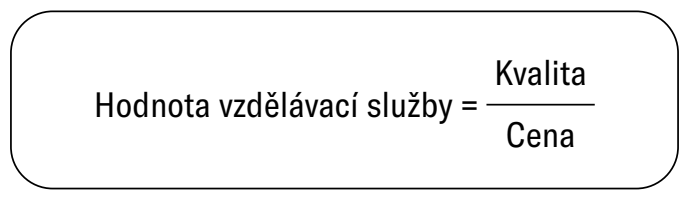

Obrázek 3: Hodnota vzdělávací služby

Přitom vnímaná hodnota vzdělávací služby je ovlivňována psychologickými či psychografickými faktory a kvalitou vzdělávací služby rozumíme především kvalitu uznanou klientem či zákazníkem školy. Ta je dána rozdílem mezi kvalitou skutečně vnímanou a očekávanou.

\footnotetext{
${ }^{8}$ Námětem do diskuse z pedagogického pohledu je, že sem řadíme i připadné psychické a fyzické vypětí, které je potřebné pro získáni produktu.
} 


\subsection{Místo - distribuce}

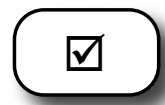

Klasická marketingová poučka uvádí: Správný produkt, ve správné kvalitě, za správnou cenu, ve správné době a na správném místě.

Do distribuce zařazujeme vše, co je potřebné, aby zákazník / klient vzdělávací službu obdržel. Podle Světlíka (2009) je cílem efektivní distribuce vytvoření co nejvhodnějších podmínek pro studium nabízeného vzdělávacího programu, a to při nákladech přijatelných jak pro školu, tak i pro jeji žáky a jejich rodiče.

U vzdělávací služby se jedná o rozhodnutí, komu, kdy, kde a jakým způsobem službu dodáme ${ }^{9}$. Přitom povaha distribučních cest se bude odvijet od toho, o jaký vzdělávací produkt se jedná. Mateřská školka bude nabizet svoji službu skutečně jen pro své nejbližši okolí. Jinak tomu bude již u středních škol v regionu a o to více u specifických středních škol, které jsou někdy i výjimečné (např. výroba hudebních nástrojů). U vysokých škol a v celoživotním vzdělávání v různých dálkových, kombinovaných a distančních formách studia je často distribuce mixem prezenční výuky, tutoriálů, e-learningu či korespondenčních kurzů, soustředění, exkurzí atd.

\section{! Na distribuci vzdělávací služby má vliv:}

- Umístění vzdělávacího subjektu, ale i objektu vzdělávání.

- Dostupnost vzdělávacího subjektu (zvažte: umístění může být dobré, ale dostupnost z hlediska změn v dopravě je špatná, + máte dobrý bezbariérový přístup? atd.).

- Vybavenost školy (odborné učebny a zařizení, knihovna či informační centrum, vybavení pro e-learning aj.).

- Rozvrh (velmi významné pro další a celoživotní vzdělávání, ale i u prezenčního studia v návaznosti na dopravu dojiždějících studentů a učitelů atd.).

\footnotetext{
${ }^{9}$ Jako experta na e-learning mne před Covidem ani nenapadlo, že by se e-learning mohl stát hlavní distribuční cestou i na našich základních školách (dále viz Eger, 2020). Nicméně, změnil se i tzv. Školský zákon a minimálně hybridni vzdělávaci cesta nebude již nic neobvyklého i pro naše ZŠ a SŠ. Jak to jednotlivé školy zvládaly z hlediska marketingové komunikace? V roce 2021 zahájilo MŠMT projekt pokusného ověřováni kombinovaného vzděláváni se zapojením 72 škol, od malotřidek, po velké SŠ.
} 
- $\quad$ Prostředí (i u škol má vliv ekologie či bezpečnost prostředí aj.).

- Způsob distribuce (od klasické prezenční výuky ve škole a v obci až po distribuci vzdělávání s využitím ICT ${ }^{10}$ ).

Významnou roli v distribuci hraji i různí zprostředkovatelé či subdodavatelé.

\subsection{Marketingová komunikace}

\section{$\square$}

Komunikace je mízou každého marketingového úsilí (Lockhart, 2016a). Je jedno, zda se jedná o komunikaci psanou nebo mluvenou, verbální nebo nonverbální, interpersonální, skupinovou nebo masovou, tradiční nebo digitální. Komunikace prostřednictvím různých komunikačních kanálů významně ovlivňuje celkový dojem (image), který si lidé o škole utvárejí. Efektivní komunikace musí respektovat cílové skupiny př́ijemců sdělení, ale musí podporovat také interakci a vnímat zpětnou vazbu.

Stručnou obecnou definici uváději například Karličck a kol. (2016, s. 10) následovně: „Jedná se 0 „řízené informování a přesvědčování cílových skupin, pomocí kterého naplňují firmy a další instituce své marketingové cíle“.

Pokud vyjdeme ze zaměření pro podnikové prostředí, potom opět použijeme vymezení dle Kotlera a Kellera (2013, s. 516), kteři definuji marketingovou komunikaci ${ }^{11}$ následovně: „Marketingová komunikace je prostředkem, kterým se firmy snaží informovat, presvědčovat a upomínat spotřebitele - prímo či neprímo - o výrobcích nebo značkách, jež prodávaji.." Autoři dále zdůrazňuji, že marketingová komunikace pomáhá společnostem propojit jejich značku s jinými lidmi, událostmi, zážitky, místy, pocity a věcmi. V souvislosti se značkou může marketingová komunikace přispět i k její hodnotě v případě, že si tato značka vytvoři svoji image a spotřebitelé si ji tak zafixují, stejně tak může přispět $k$ růstu tržeb a hodnotě pro akcionáře. To je aplikovaně velmi dobře použitelné i pro marketing školy, protože prezentace školy jako značky je soudobý marketingový trend.

\footnotetext{
${ }^{10}$ Zajímavým př́ikladem je subjekt Školy na konci světa (B̌̌ezová), který distančni vzdělávání na úrovni ZŠ a SŠ s podporou ICT realizuje již řadu let.

${ }^{11}$ Marketingové komunikace vycházi z obecného modelu komunikace a jsou širšim pojmem než propagace, viz i Světlík (2016, s. 4-5).
} 


\section{!}

Úkolem marketingové komunikace školy je komunikování se zákazníky školy v nejširším slova smyslu, s dalšími vzdělávacími subjekty a s celým okolím školy. Podstatou je schopnost školy sdělovat svou vizi a své poslání a prezentovat svou nabídku služeb a tím vytvářet a podporovat svou pozici a svoji image. Stejně významná jako komunikace s okolím (s vnější veřejností) je i cílená vnitřní komunikace (s vnitřní veřejností).

Škola musí dát vědět o své existenci a seznámit veřejnost s důležitostí a účelem vzdělávacího programu, který poskytuje, musí přesvědčovat o výhodách své nabídky atd. Na druhou stranu také potřebuje znát požadavky a prání relevantních cílových skupin, a i proto potřebuje rozvijet interakci v komunikaci.

Mezi základní nástroje komunikačního mixu řadíme: reklamu, podporu prodeje, osobní prodej, Public Relations a přímý marketing. ${ }^{22}$

„Většina marketérů tedy nestojí před otázkou, zda komunikovat, ale spíše před otázkou, co říci, jak a kdy, komu a jak často.“

(Kotler \& Keller, 2013, s. 515)

Z pohledu současné školy v kontextu ČR na regionální úrovni jsou velmi důležité její webové stránky, aktivity řazené do Public Relations, ale i „osobní prodej“ (tj. komunikace ředitele, třídního učitele s rodiči apod.) a klíčovým je tzv. WOM ${ }^{13}$ (slovo z úst, tj. to, co si lidé o škole říkaji), který škola může ovlivňovat pouze nepřímo. Některé zejména SŠ výrazně využívají klasickou reklamu, stále více se prosazují sociální média. Jednotlivé součásti komunikačního mixu v publikaci dále objasníme a uvedeme př́klady z oblasti marketingu škol.

Pro organizaci marketingové komunikace školy nám může dobře sloužit tzv. zobrazení typů marketingu v oblasti služeb, viz obrázek 4. Dríve byla marketingová komunikace často redukována jen na základní komunikaci - propagaci školy směrem ven. To ovšem není správné.

\footnotetext{
${ }^{12}$ Někteři autoři těchto pět základních doplňuji o dalši nástroje. Například Kotler a Keller (2013) rozšiřuji komunikační mix o události a zážitky, interaktivní marketing a ústní šiření. Přikrylová a kol. (2019) doplňují komunikačni mix o sponzoring a veletrhy a výstavy.

${ }^{13}$ Word of Mouth Marketing. Jednoduše si jej můžete vyzkoušet, pokud napřiklad s vlastním dítětem zajdete mezi maminky na veřejné piskoviště a budete naslouchat. Hned budete vědět co si „veřejnost“ povídá o jednolivých MŠ či ZŠ, jejích učitelích atd.
} 


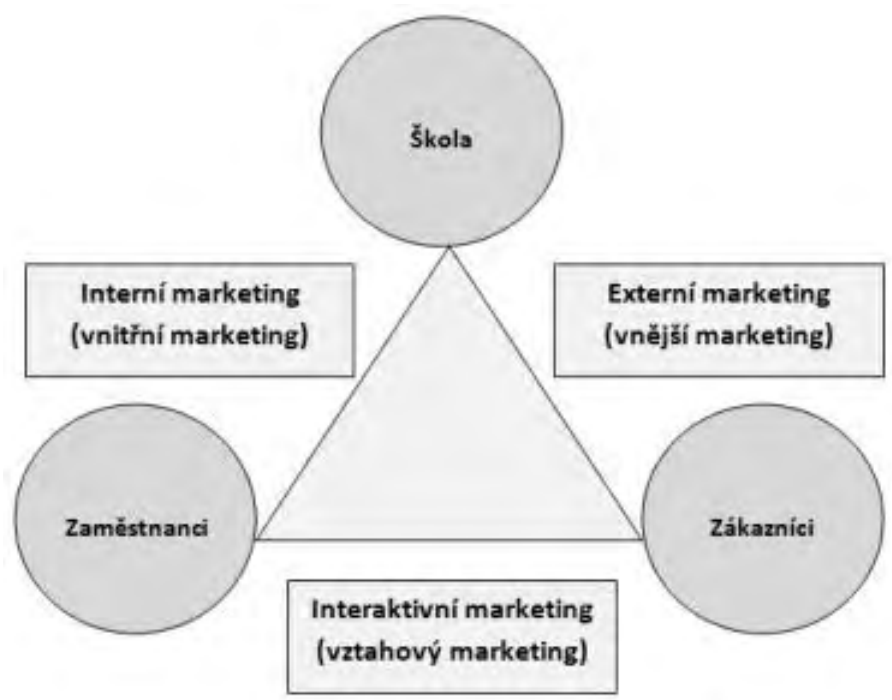

Obrázek 4: Typy marketingu v oblasti služeb

\section{!}

Marketingová komunikace má 3 obecné cíle: informovat, přesvědčovat a připomínat. Směrem dovnitř školy (interní marketing) můžeme cíle upravit na: informovat, motivovat, a vytvářet podmínky (zejména pro vzdělávací proces).

V marketingu vztahů se klade důraz na rozvoj vztahů se zákazníky a Payne (1996) zde rozlišuje dvě etapy:

- Nejdríve se snažíme působit na potenciálního zákazníka a snažíme se z něj udělat (získat ho) zákazníka - klienta organizace.

- Důležitá je druhá etapa rozvoje vztahů, kde se organizace snaží ze zákazníka vytvářet klienta, ještě výše podpưrce své činnosti a nejvýše svého obhájce.

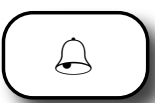

Zvažte:

Kolik různých „zákazníků“ škola má, a co by bylo potřebné dělat, aby se z nich stávali podporovatelé její vize a obhájci mise školy? 
Technologie a dalši faktory zásadně mění způsoby, jakými spotřebitelé marketingovou komunikaci zpracovávají, a dokonce i to, zda se ji vůbec zpracovávat rozhodnou. Zvažte, že zejména z hlediska uživatelů jsou rodiče dnes většinou $z$ Generace $Y$ a bude nastupovat Generace Z. Tzn. jsou spojeni s rozvojem ICT a preferují komunikaci prostřednictvím internetu (viz i Friedlaenderová, 2019).

\subsection{Základní vymezení nástrojů komunikačního mixu}

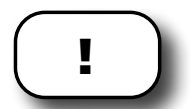

Reklama

Dle Kotlera a Kellera (2007) je reklama jakákoliv placená forma neosobní prezentace a propagace ideji, zboží nebo služeb. Podobně Světlík (2006) uvádí, že se jedná o placenou formu neosobní, masové komunikace uskutečňovanou prostřednictvím tiskových médií a zdưrazňuje, že jejím cílem je informování širokého okruhu zákazníků se záměrem ovlivnit jejich kupní chování. ${ }^{14}$

Uvedené samozřejmě platí i pro oblast vzdělávání. Střední, vysoké školy a další organizace působící na vzdělávacím trhu běžně využivají různá média a nosiče reklamních sdělení. Specifické postavení získávají prezentace škol a vzdělávacích produktů na internetu, kdy se ne vždy jedná prímo o reklamu, a tedy o placenou neosobní prezentaci.

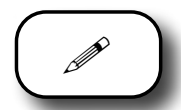

Z tzv. masových médii (ATL) školy hodně využívají inzerci v tisku (noviny i časopisy), spoty v rozhlase (regionální i celostátní), venkovní reklamu (v tom např. billboardy, reklamní plachty, orientační cedule, lavičky, plakáty aj). Z televize jsou spíše využivány regionální kanály, protože placená reklama $v$ celostátních kanálech je zejména pro regionální školy velmi drahá a částečně ne dobře cílená. V oblasti internetu školy využivají řadu forem bannerové, ale zejména PPC reklamy. Stále více se $v$ napojení na www stránky subjektu využivá i komunikace v sociálních médiích (Facebook, Youtube, Instagram...), kterou řadíme spíše do $B T L^{15}$.

\footnotetext{
${ }^{14}$ Vysekalová a Mikeš (2018, s. 14) uváději, že „existuje mnoho definic reklamy, ale to, co maji společné, je, že jde o komunikaci mezi zadavatelem a tím, komu jsou nabizený produkt či služba určeny, prostřednictvím nějakého média s komerčním cilem."

${ }^{15} \mathrm{ATL}$ = masová komunikace (above to line), BTL (below to line) spiše více cílená a personalizovaná komunikace. Dnes se použivá integrovaný přistup (TTL) s využitím účelné mixu médii a jejich prostředků
} 


\section{! Podpora prodeje}

Dle Kotlera a Kellera (2007) se jedná o rozmanité krátkodobé podněty vybízející k vyzkoušení nebo nákupu určitého výrobku nebo služby. Podpora prodeje působí spiše krátkodobě a ve školství ji známe z aktivit, jako jsou dny otevřených dveří nebo prezentace na veletrzích vzdělávání, kde je ovšem propojena i s Public Relations a často i s osobní komunikací zájemců o studium se zástupci školy.

Obecně můžeme podporu prodeje charakterizovat jako proces zaměřený v první řadě na komunikaci a poskytování podnětů. Kotler a Keller (2007, s. 624) výstižně charakterizuji rozdíl mezi reklamou a podporou prodeje takto: „Zatímco reklama nabízi důvod koupit, podpora prodeje nabízi speciální podnět ke koupi.“

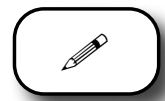

Pro bližší představu si uvedeme příklady základní aplikace forem podpory prodeje ve školství v zaměření na „spotřebitele“.

- Kupony školy - „poukázky“, které vydává subjekt - fixní úspora za kupón napřiklad pro sourozence či dalšiho účastníka vzdělávaci služby. Využívají některé soukromé školy, ale také např. DDM pro „nákup“ dalšího kurzu apod.

- Slevy z ceny - jedná se o typ finanční pobídky, škola se zavazuje, že klientovi pokryje za určitých podmínek například dopravu či poštovné. Využivá se napřiklad v některých kurzech dalšího vzdělávání.

- Rabat - v prípadě podpory ve vztahu ke spotřebitelům má rabat $v$ podstatě stejnou funkci jako sleva z ceny, rabat je určen pro zboží dlouhodobé spotřeby a je (bez tohoto pojmenování) opět využíván při „nákupu“ či opakován zakoupení např́klad vzdělávacích kroužků.

- Cenové balíčky - opět se jedná o finanční pobídku, jejímž úkolem je podpořit produkt tím, že je dočasně nabizen za nižší cenu. Než z prostředí MŠ, ZŠ a SŠ, známe z prostředí ZUŠ nebo DDM a podobných vzdělávacích či volnočasových služeb.

- Prémie - dárky jsou podporou produktu, kdy škola zvyšuje zákazníkem (klientem) vnímanou hodnotu produktu pomocí extra prídaného dárku. Tímto dárkem mohou být i studijní texty či jiné materiály podporující studium. 
- Spojení - školy mohou v některých připadech společně podporovat prodej jednoho či více druhů produktů. Společné učebnice a dalši studijní materiály, společný kurz, výjimečně i společný studijní program.

- Program odměn - studující obvykle sbírá body... a může získat slevu na doplňkové kurzy a aktivity. Známe spiše z dalšího a celoživotního vzdělávání.

- Loterijní hry - podpora umožňuje zákazníkům vyhrát ceny (slosování). V kontextu ČR se použivá výjimečně, výjimkou jsou tomboly na plesech škol.

- Soutěže - mohou být hrou či kombinaci her a loterií. Myslíme tím zákaznické soutěže, které se stávají nejúčinnější aktivitou v prostředí sociálních médií a vytvárení tzv. komunit značek ( $v$ tomto smyslem to nemá nic společného se soutěžemi dětí jako jsou olympiáda v předmětech apod.).

- Vzorky - jedná se o produktovou podporu školy, která poskytuje spotřebiteli vzorek produktu a to bud' bezplatně, nebo za symbolickou cenu. Z prostředí našich škol například známe jako ukázkové hodiny a možnost otevřených návštěv výuky na vyšším stupni škol.

Z uvedeného seznamu je patrné, že paleta možných nástrojů je bohatá.

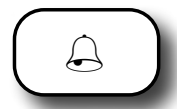

Mezi nástroje podpory zaměřené na školu a její učitele řadíme konference, školení, soutěže pro učitele, incentivní pobídky (zájezdy) a specializovanou reklamu (vybavení a pomůcky pro předmět dle aprobace...).

Pelsmacker a kol. (2003) uvádějí, že: efektivita podpory prodeje výrazně souvisí s charakterem zákazníků. Ve vyspělých zemích najdeme přiklady odlišného využívání podpory prodeje pro školy na okraji měst proti podpoře prodeje pro jinou cílovou skupinu s jiným socio-ekonomickým zázemím, která chce umístit své děti v prestižních veřejných, ale zejména soukromých školách. Řadu podobných přikladů Ize již najít i v kontextu ČR.

Obecně se předpokládá, že podpora prodeje velmi oslovuje spotřebitele, kteří jsou citliví na cenu, hledají nízkou cenu či bedlivě porovnávají cenu a kvalitu nebo je osloví nabídnutá prémie (at ve smyslu slevy nebo speciální ceny, výhodného baleni apod.). 


\section{! Osobní prodej}

Obvykle se definuje jako osobní interakce zástupce školy se zákazníky. Zde se projevuje další specifikum marketingu v oblasti školství, protože ta nejdůležitější interakce se odehrává ve vzdělávacím procesu nebo při setkání rodičů s učitelem či ředitelem školy ${ }^{16}$ atd. Pedagogický akcent osobního prodeje v oblasti školství jej odlišuje od podnikatelské sféry, kde převládá zaměření na prodej produktu nebo služby.

Pedagogové si stále ještě málo připouštějí, že jsou v komunikaci se žáky či studenty a rodiči či absolventy $i$ aktéry přimého prodeje a velmi důležitého interního i externího marketingu! $!^{17}$

\section{Každý zaměstnanec školy by se měl stát jejím ambasadorem!}

Samožrejmě specificky důležitou roli zde hraje ředitel/ka školy a jeho či její veřejná vystoupení. Významná je např. jeho či její prezentace na Dni otevřených dveři nebo tzv. burze škol atd. ${ }^{18}$

\section{Public Relations}

Vztahy s veřejností jsou velmi významnou součástí komunikačního mixu škol. Dle Světlíka (2009) se jedná o takovou formu komunikace, jejímž hlavním cílem je vytváření pozitivního zobrazení školy a jejího vzdělávacího programu u relevantní veřejnosti (srovnej s image organizace).

Kromě budování důvěryhodnosti školy by PR jako nástroj komunikačního mixu měl přispívat $\mathrm{k}$ stimulování zájmu o školu a její služby, podporovat dřive uvedené vztahy se zákazníky a partnery školy, připadně přispívat k získávání sponzorů..$^{19}$ Světlík (2009, s. 221) dodává ještě i snižování nákladů na efektivní komunikaci školy s veřejností.

\footnotetext{
${ }^{16}$ Kličová je komunikace, kde vedeni škol nebo učitelé vyřizuji stížnosti rodičů. Může se někdy jednat i o součást krizové komunikace. Určitým problémem je, že „každý byl ve škole“ a tedy „každý dobře ví, co by se mělo dělat“. Není vždy jednoduché profesionálně a v klidu reagovat na neoprávněné až útočné poznámky, maily atd.

${ }^{17}$ Téma úzce souvisí s vnitřním marketingem, ale i s leadershipem a s tzv. delegováním. V zahraničí se použivá distributed leadership (Bush, 2013). Podobně Hašková (2010) = participativní řizení.

${ }^{18}$ Opět vidíme prolínáni nástrojů marketingového mixu, protože uvedené také patří do Public Relations.

${ }^{19}$ Poživáme také pojem Fundraising.
} 


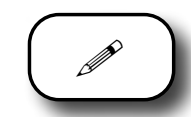

- Můžeme sem řadit různé akce a propagační aktivity sloužící k budování a udržení image školy. Akce - eventy se snaži vyvolat zážitky, jež príznivě působí nejenom racionálně, ale i emocionálně na cílovou skupinu a přispívají k budování pozitivních vztahů cílové skupiny ke škole, jejímu programu atd. (srovnej s positioningem).

- Určitě sem patří komunikace s médii a informování (vytváření zpráv) o aktivitách školy pro média. Každá významná událost organizovaná školou je vlastně přiležitostí pro PR. Jak jsme již výše uvedli, patři sem veřejná vystoupení zástupců školy, ale také aplikace jednotného vizuálního stylu školy, propagační materiály školy atd. Specifickým nástrojem PR, který je dokonce dán Školským zákonem, je výroční zpráva školy. ${ }^{20}$

- Silným komunikačním nástrojem pro PR jsou www stránky školy a využití komunikace na sociálních médiích, a to zejména proto, protože důležité cílové skupiny, tj. žáci či studenti a jejich rodiče využivají především internetu pro získávání informací a interakci. ${ }^{21}$

Public Relations souvisí s WOM a můžeme uvést, že se pravděpodobně dnes jedná o nejsilnější formu komunikace většinou vycházející z image a reputace školy.

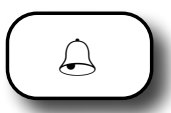

S tím ale souvisí i další problém, na který již upozornil Světlík (2009) a který je ještě významněji spojen právě s komunikací na internetu (Janouch, 2020). U Public Relations existuje jen malá možnost kontroly obsahu sdělení včetně toho, kdy a jak mu bude veřejnost vystavena (dnes zejména vliv sociálních médii). Je to na jedné straně forma komunikace, jež může mít své výhody ve vyšší důvěryhodnosti pro príijemce sdělení a případně i v délce sdělení, ale na straně druhé se může zejména na internetu stát obětí útoků tzv. hejtrů a Fake News.

\section{Efektivní komunikace v krizi}

K Public Relations patři také krizová komunikace. Včasné podání správných informací relevantním interním i externím skupinám je klíčovou záležitostí pro

\footnotetext{
${ }^{20} \mathrm{~K}$ tomu vice podrobnosti v príloze $\mathrm{C}$.

${ }^{21}$ Proto www stránkám školy a komunikaci prostřednictvim sociálnich médii věnujeme speciální kapitolu.
} 
zvládání krize. Zejména žáci či studenti a jejich rodiče by měli slyšet informace ke krizové situaci od osoby, které důvěřjí. Škola by měla mít plán pro krizovou komunikaci a určeno, kde je mluvči. ${ }^{22}$

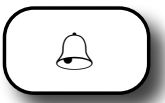

Co je potřebné obecně sdělit médiím?

Jsou to odpovědi na klasické otázky: co se stalo, koho se to týká (není vhodné používat konkrétní jména), kde a kdy se to stalo, jak se to stalo a co se v současné době dál odehrává.

Některá dalši doporučení dle Eger a kol. (2002) a Lockhart (2016a): uved'te jako první nejdůležitějši fakta, nespekulujte, když odpovídáte na dotazy, pokud něco nevíte, sdělte, že nevíte, mluvte pravdu, vše by mělo být zaznamenáno, nehádejte se se zástupcem médií, hned upřesněte chybné informace či interpretace, rychle poskytujte slíbené dodatečné informace. Zvažte také zda nevyužijete externího experta při zvládání skutečně závažné krizové situace.

Krizový management, včetně krizové komunikace, musí být připraven před krizí. Velmi důležité je předvídání krize.

\section{People - lidé ve škole}

\section{Většinu vzdělávacích organizací představuji především lidé. Lidé jako nejcennější a nejdůležitější zdroj organizace. Toto doplňující „P“ je pro vzdělávání specificky důležité!}

Důležitost lidí - zaměstnanců spočivá v tom, že se podílejí na tvorbě služeb a jejich kvalitě, jsou v bezprostředním kontaktu se zákazníky (viz i specifika služeb).

- Z $\quad$ pohledu marketingového řízení školy se řizením a vedením lidí, jejich motivací, týmovým managementem a otázkami vnitřní komunikace zabývá vnitřní (interní) marketing.

- Vnitřní marketing je způsob řízení pracovníků školy vedoucí k tomu, aby fungovali jako motivovaný tým odborníků, jehož cílem je co nejvyšší stupeň naplněni poslání a cilů školy, a tím i uspokojení potřeb jejích zákazníků a klientů.

${ }^{22} \mathrm{~V}$ našich podmínkách to bude obvykle ředitel/ka školy. 


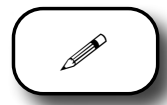

V materiálech pro NPI Světlík (2020) do vnitřního marketingu zahrnul následující kličové body:

- Výběr a získáváni pracovníků.

- Efektivní vedení lidí (leadership). ${ }^{23}$

- Motivace lidí.

- Vnitřní komunikace.

\section{(-) Vybudujte si marketingový tým}

Lockhart (2016a, b) uvádí, že ačkoliv marketing se týká každého, kdo je ve škole jako zaměstnanec nebo žák, je vhodné si vytvořit motivovaný tým, který bude plánovat, koordinovat, implementovat, a i monitorovat a vyhodnocovat marketing vaši školy. Samozřejmě je to složité u malotřídky, ale je to možné u větších základních škol a mělo by a rozhodně je to doporučené pro všechny větši vzdělávací subjekty. Vedoucím týmu musí být ředitel/ka školy. Naopak součástí týmu nemusí být jen zaměstnanci školy, ale je možné zapojit například rodiče se zkušeností z marketingu, případně jako poradce či konzultanty přizvat pro klíčová rozhodnutí i externí pracovníky.

Pokud začínáte, je vhodné sestavit spiše menší tým (ředitel/ka a 3-4 další lidé), který zaháji svou práci přípravou auditu a návrhem cílů v oblasti marketingu. Lockhart (2016a) doporučuje, aby členové týmu byli lidé, kteři věři v účelnost marketingu, byli ochotní spolupracovat v dlouhodobém období a byli dobři $v$ oblasti komunikačních dovednostíi ${ }^{24}$. Zvažte, že velmi důležité je mít schopnosti pracovat $v$ týmu i individuálně, a zejména zvažovat i jiné pohledy na věc. (pro získání podnětů využijte jednoduchou metodu terče, přiloha H).

\section{! Cíl marketingového komunikačního mixu}

Cílem marketingového komunikačního mixu může být: seznámení cílové skupiny se vzdělávacím programem školy a s jejími doplňkovými službami,

\footnotetext{
${ }^{23}$ Přesah do managementu je zřejmý. Odkazujeme na Everard, Morris, \& Wilson (2004), Pisoňová a kol. (2014), Bush (2013). Zajímavá je i studie z českého prostredí, Trojan a Svobodová (2019).

${ }^{24}$ Profesním rozvojem učitelů se zabývaji napřiklad Pavlov a kol. (2018). Při zvažování motivace učitelů k profesnimu růstu bereme v úvahu přiležitost pro kariéru v profesi, osobnostní charakteristiky učitele, dosavadní zkušenosti a kvalitu podpůrných (externich) služeb.
} 
přesvědčení zájemců $\mathrm{k}$ přihlášení se ke studiu, získání věrných zákazníků (studentů, absolventů, účastníků kurzů...), zvýšení frekvence a objemu nákupu (spiše u celoživotního vzdělávání), lepší povědomí veřejnosti a cílových skupin o škole, interakce se zákazníky školy v nejširším smyslu atd. $\mathbf{K}$ dosažení cílů komunikace je vhodné kombinovat prvky komunikačního mixu a přihližet ke specifikům nabízené vzdělávací služby a $k$ procesu nákupu (termíny prijímacího řizení apod.).

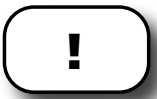

\section{Přímý marketing}

Př́mý marketing představuje přímou komunikaci s vybranými segmenty zákazníků, kterou je sdělována speciální nabídka s cílem získat co nejrychleji odezvu a zároveň budovat dlouhodobé vztahy s těmito zákazníky (podle Postler \& Bárta, 2020). Je také pojmenováván jako interaktivní marketingová technika (Vysekalová \& Mikeš, 2018) využívající jedno či více médií $k$ dosažení měřitelné odezvy. $Z$ uvedeného vymezení je zřejmé, že i př́mý marketing bude zajímavý pro marketing škol v rámci integrované marketingové komunikace.

Je samozřejmě evidentní, že regionální školy nebudou využívat teleshopping či telemarketing, ale bude pro ně zajímavé oslovování cílových skupin s využitím direct mailu, přímého (osobního) prodeje a velmi důležitá je oblast WOM. Právě Kotler a Keller (2013) sem zařazuji i komunikaci prostřednictvím webových stránek a mobilních zařizeních a my se této oblasti budeme specificky věnovat $v$ kapitole zaměřené na marketing na internetu včetně komunikace na sociálních sítích.$^{25}$ Opět nás bude zajímat, jak přimý marketing může mimo jiné v kooperaci s reklamou či Public Relations atd. přispět k vytváření značky školy a její pozitivní image.

\subsection{Holistická koncepce marketingu}

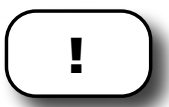

Dnes se snažíme marketingovou koncepci vytvářet na základě tzv. integrované marketingové perspektivy, která v holistickém pojetí marketingu (Kotler \& Keller, 2007) staví na následujících niže uvedených propojených částech.

\footnotetext{
${ }^{25}$ Opět je zde patrné prolináni nástrojů marketingového mixu. Kde všude můžeme v komunikaci počítat s www stránkami, sociálními médii atd.?
} 
Podstatou této orientace je následující tvrzení: „Holistické marketingové pojetí je postaveno na vývoji, designu a plnění marketingových programů, procesů a aktivit beroucích v úvahu jejich širíi a vzájemnou propojenost. Holistický marketing zastává názor, že u marketingu záleží na všem - a že je často zapotřebí široká, integrovaná perspektiva." (Kotler \& Keller, 2007, s. 55)

- Vztahový marketing - je zaměřen na budování vzájemně výhodných dlouhodobých vztahů se zákazníky a partnery školy.

- Integrovaný marketing ${ }^{26}$ - je orientován na marketingové programy, jeho hlavní zaměření je na vytváření hodnot pro zákazníky, práci s marketingovým mixem a vytváření koordinovaných marketingových aktivit školy.

- Interní marketing - ten je zaměřen dovnitř školy na učitele a zaměstnance, ale je propojen i s jejich osobní komunikací se zákazníky a propagováním školy atd.

- Společensky zodpovědný marketing - v oblasti školství souvisí zejména s hlavním posláním škol, s kultivací mladých lidí, s předáváním kulturního dědictví, ale i s výchovou člověka platného pro naši společnost atd.

\section{(ن)}

Světlík (2009, s. 27) v této souvislosti použivá pojem relační marketing a uvádí, že k jedinečným know-how školy může patřit sít vztahů, které si škola se svým okolím vytvořila. Z hlediska aplikace do praxe je velmi výstižné jeho tvrzení: „Chytrý ředitel školy si je vědom toho, že úspěch školy nemůže být postaven pouze na směnných vztazích, ale na dlouhodobých, důvěrných a poctivých vztazích s rodiči, absolventy, podniky, školskými institucemi a tak dále. Těchto vztahů Ize např́klad dosáhnout trvalou kvalitou poskytovaných vzdělávacích služeb, včasným a poctivým informováním o aktivitách a výsledcích školy, akceptováním oprávněných připomínek k činnostem školy, posilováním společenských pout mezi školou a jejími partnery. Dobré a silné vztahy přinášeji užitek jak škole, tak i jejím partnerům..."

Budování těchto vztahů směrem dovnitř i vně školy souvisí s propojováním aktivit souvisejících s aplikováním nástrojů marketingového mixu v praxi.

U budování externích vztahů potom Lockhart (2016b) zdůrazňuje, že v současné době se školy zaměřuji daleko více na budování dlouhodobých vztahů

\footnotetext{
${ }^{26}$ Lockhart (2016a) v integrovaném marketingu pro školy vyzdvihuje Public Relations, vztahy s médii, komunikaci obecně, reklamu a vztahový marketing. To vše jako součást orientace na úspěch v marketingu školy.
} 
se svými partnery, než tomu bylo v dřivějším období. Partnerství by podle něj mělo být nepřetržité a oboustranně výhodné. ${ }^{27}$

\section{$\square \quad$ Integrovaná marketingová komunikace}

Na závěr této kapitoly si ještě vymezíme pojem integrovaná marketingová komunikace, jež s holistickým př́stupem přímo souvisí. Belch a Belch (2021) uvádějí, že při implementaci integrované marketingové komunikační strategie organizace kombinuji různé prvky komunikačního mixu a snaží se přitom vybalancovat výhody a nevýhody každého z těchto prvků a vytvořit tak efektivní komunikační program. Zahrnuje to proces plánování, realizování, evaluace a kontroly při využívání různých komunikačních mixů s cílem efektivně komunikovat s cílovými skupinami (zvažte nástroje komunikačního mixu v přiloze B).

Tato obecná definice plně platí i pro školy, ale je u ní nutné přihližet ke specifikům např́klad regionálního školství, jež naplňuje veřejnou vzdělávací službu.

\section{? Kontrolní otázky a úkoly:}

- Která součást kurikula je z pohledu reputace školy nejdůležitější?

- Co to jsou tzv. specifika služeb, uved'te příklady pro vzdělávání.

- Co znamená, že cenu (náklady) pro zákazníka nevyjadřujeme jen penězi?

- Doplňte: efektivní distribuce vzdělávacího programu znamená...

- Jaké tři obecné cíle má marketingová komunikace?

- Jaké základní nástroje použivá tzv. komunikační mix?

- Dokážete uvést příklady komunikace školy s veřejností, která dnes již neexistuje, a naopak úplně nové príklady komunikace?

- Proč je vnitřní marketing jednou z nejdůležitějších částí marketingu školy?

- Které jsou hlavní překážky pro jeho uplatňování na vaší škole?

- Dokážete svými slovy objasnit podstatu relačního marketingu?

${ }^{27}$ Marketingovému týmu zde doporučuje stanovit si cíle, následně jejich priority a dvě až tři nejvyšší na seznamu rozpracovat jako projekty (Lockhart, 2016b, s. 35). 
[DD Literatura:

Kotler, P., \& Keller, K. L. (2013). Marketing management. Praha: Grada.

Světlík, J. (2009). Marketingové rízení školy. Praha: Wolters Kluwer.

Světlík, J. (2016). Marketingové komunikace. Praha: VŠPP Praha a.s. Dostupné z: http://www.marketingsvetlik.cz/

Pisoňová, M. a kol. (2014). Školský manažment pre študijné obory učitelstva a pripravu vedúcich pedagogických zamestnancov. Bratislava: Univerzita Komenského v Bratislave. Dostupné z: https://www.fedu.uniba.sk/file admin/pdf/Sucasti/Katedry/KP/KAPESO/Skolsky_manazment.pdf 


\section{STRATEGICKÉ PLÁNOVÁNÍ ROZVOJE ŠKOLY}

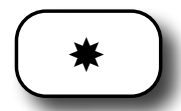

\section{Cíle:}

- Diskutovat potřebu strategického plánu rozvoje školy.

- Seznámit se s odpovědností za strategické rízení.

- Prohlédnout si základni strukturu strategického plánu školy.

- Získat náměty pro práci na strategii školy.

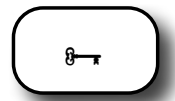

\section{Klíčová slova:}

strategické řizení, strategický plán školy, klíčové oblasti

8 Čas potřebný ke studiu základního textu kapitoly je cca 10 minut + možnost rozšírení o studium externích zdrojů $\mathrm{z}$ internetu.

\section{Úvod}

Strategické plánování rozvoje školy se stává důležitou a aktuální problematikou v souvislosti se zvyšující se autonomii škol. ${ }^{28,29}$ Strategické rozvojové plány škol byly v devadesátých letech velkou novinkou ve školském managementu. $V$ současné době jsou již běžně požadovány jak zřizovateli škol, tak i kontrolními orgány. Dokonce běžnou součástí konkurzu na ředitele školy je i diskuse nad jeho představou o vizi a poslání školy a nad hodnocením současného stavu, což ve stručnosti představuje základní stavební kameny strategického plánování.

\footnotetext{
${ }^{28}$ Managementy škol v ČR maji přitom jednu z nejvyšších autonomii ve světě, dle srovnávaci studie OECD (Schleicher a kol., 2012).

${ }^{29} \mathrm{~V}$ rozsáhlém výzkumu školského managementu na Slovensku bylo prokázáno, že 90 \% vedoucích pracovníků ohodnotilo vytvářeni strategie rozvoje školy s nejvyšši důležitosti (Hašková, 2010).
} 
Strategický plán rozvoje školy by měl být jedním z nejdůležitějších dokumentů školy. Rozhodně by se neměl stát formální záležitostí, ale díky týmové spolupráci při jeho vytváření by měl být důležitým nástrojem při řizení rozvoje školy. Implementaci RVP a inovace ŠVP s řizení kvality vzdělávání ve škole si Ize jen stěži představit bez vytváření a inovace strategického plánu rozvoje školy.

V této kapitole si ukážeme možné př́stupy ke strategickému plánování ve škole a na základě rozboru odborné literatury budeme prezentovat stručné, ale přehledné schéma postupu. Je vhodné také poznamenat, že téma je součástí vzdělávání managementu škol a že například NiDV ${ }^{30}$ od roku 2016 realizovalo rozsáhlý projekt Strategické řízení a plánování ve školách a v územích, který podpořil stovky škol v ČR.

\section{?}

Proč potřebujeme strategický plán rozvoje školy?

Každá cílevědomá lidská činnost vyžaduje plánování, protože tak dochází $k$ eliminaci či minimalizaci neefektivních postupů a cesta $k$ cíli se plánováním harmonizuje a racionalizuje. To znamená, že strategický plán tímto přispivá k rozvoji školy.

- Dochází k lepšímu využití lidských, materiálních a finančních zdrojů, ale také času a informací (Elsner, 2001).

- Plán pomáhá lépe reagovat na výzvy budoucnosti v zájmu rozvoje a vzdělávání žáků a studentů a též rozvoje učitelů a školy jako celku.

- Strategický plán funguje jako kompas v zaměření činností, staví na vizi, misi, prioritách a hlavních cílech školy.

- Vytvárí potřebné zaměření na budoucnost, které nedovoluje „pouhé utopení se“ v každodenních činnostech a starostech. Vedení školy nutí přemýšlet o budoucnosti systematickým způsobem (Majaro, 1996).

- Jeho společné vytváření a zainteresování všech zúčastněných ve škole podporuje synergický efekt v dalši práci a přispivá k pozitivnímu klimatu i vytváření potřebné kultury školy (Eger, 2006; Lockhart, 2016a).

- Plánování umožňuje zlepšit komunikaci uvnitř školy a vyhnout se tak rizikům a konfliktům ve sboru i mezi vedením a dalšími pracovníky.

- Rozvojový plán také umožňuje jeho externí využití ve spolupráci s dalšími externími partnery školy. Je také využitelný v marketingu a propagaci školy.

\footnotetext{
${ }^{30}$ Informace a materiály ke stažení z tohoto projektu NiDV najdete na: https://projekty.nidv.cz/strategicke-rizeni, autor publikace se účastnil, jako jeden z expertů, prípravy realizace modulů projektu a potom i jako lektor následného kurzu k marketingu školy.
} 
- Plán rozvoje je vlastně plánováním změn, a proto je on sám, ale hlavně i proces jeho utváření důležitou součástí pozitivního zaměření na potřebné změny.

- Za další prínos je možné podle Elsner (2001) označit dosažení lepší pozice vůči konkurenci v oblasti vzdělávání. Podobně Majaro (1996) zdůrazňuje lepši přizpůsobení zdrojů možnostem trhu a tento bod bude nabývat na významu v souvislosti s např. demografickým vývojem, ale i dalšími změnami ve společnosti a globalizovaném světe. atd.

- Nastoupení do spirály úspěchu, kdy jeden úspěch podporuje další a konsolidaci úsilí na rozvoj celého společenství ve škole (Elsner, 2001).

- Plán umožňuje průběžné sledování činnosti (Jakubíková, 2008; Majaro, 1996).

\subsection{Co je strategie organizace a strategické řízení?}

\section{$\square$}

Strategie organizace je soustava dlouhodobých cílů. Je vypracovaná na základě vize, mise a auditu. Strategické plánování je logický proces, který vycházi z analýzy. Hledáme při něm pozitivní budoucnost naší školy a optimální cestu, po které můžeme ke zvolené budoucnosti jit. Strategické plánování se nejčastěji provádí pro horizont 3-5 let.

Pokud se budeme inspirovat z klasické učebnice marketingu, potom můžeme upravit definici dle Jakubíkové (2008) následovně: Strategické řizení školy je dynamický proces tvorby a implementace rozvojových záměrů, které mají zásadní význam pro rozvoj školy. Zahrnuje aktivity zaměřené na udržování dlouhodobého souladu mezi posláním školy, jejími dlouhodobými cíli a disponibilními zdroji a rovněž mezi školou a prostředím, v němž škola existuje, a to prostřednictvím vymezení vize, mise, cílů školy, rozvojových strategii a vzdělávacího programu či portfolia vzdělávacích služeb školy. Kotler a Keller (2013) stručně uvádějí, že strategie je plán hry pro dosažení cilů společnosti.

Určitě je nutné také zdůraznit, že za strategické rízení je odpovědný vrcholový management a jednou z jeho hlavních úloh je činit i závažná strategická rozhodnutí.

Podle Světlíka (2009, s. 114) strategické plánování „odpovídá na otázku, jaké správně věci bychom měli v budoucnosti dělat, abychom byli úspěšni." 


\section{!}

Strategické řizení (aplikovaně dle Jakubíková, 2008; Kotler \& Keller, 2013) se vztahuje na:

- Rozhodování o základním smèru rozvoje školy.

- Stanovení strategických cílů (viz hlavní vzdělávací oblast a podpůrné oblasti, + velmi důležitá oblast rozvoje lidí ve škole, plnění kličových ukazatelů, jež sleduje Čšl atd.).

- Formulováni implementace strategie ( $v$ současné době velmi spojené $s$ neustálým rrizením změn v oblasti našeho školství a vzděláváni žáků a studentů).

- Stanovení pozice marketingu a zejména marketingové komunikace ve škole v souvislosti s realizaci hlavni vzdělávací funkce školy.

- Vytvá̌eni a rozvijeni strategicky orientované kultury školy.

- Vytvoření a implementaci motivačního systému.

- Rozhodování o alokaci zdrojů.

- Naplňování kontrolní funkce.

„Strategické plánování je proces, jehož výstupem je písemný dokument strategický plán, obsahující specifikaci akcí, které musí firma (škola) uskutečňovat v zájmu dosažení stanovených cílü." (Jakubíková, 2008, s.33)

\section{$\square$}

Plánování rozvoje je managementem budoucnosti. Musíme si položit základní otázku (Elsner, 2001): Je budoucnost kontinuitou současnosti nebo je něčím kvalitativně jiným?

$\mathrm{K}$ této otázce jsme připojili ikonku definice. Skutečně si zde čtenář i ten (též tým), kdo chce strategicky připravovat rozvoj školy, musi uvědomit, že existuji dvě základní cesty postupu:

1. Extrapolace - předvídání trendů rozvoje na základě výsledků a procesů probíhajících $\mathbf{v}$ minulosti. Minulé má vliv na současné a budoucnost kontinuálně vycházi ze současného. Vycházi se z aktuální situace, z výsledků, kladných i záporných, ze silných i slabých stránek.

2. Anticipace - předvídání. Při plánování se vychází z toho, že budoucnost bude zásadně odlišná od současnosti. Vycházíme tedy $z$ budoucnosti. 


\section{(6)}

Obě cesty maji samozřejmě své klady a zápory. Diskuse nad nimi může být dobrým námětem k zahájení plánování rozvoje školy.

Jako námět do praxe si v tabulce niže ukážeme, jak to mění pořadí základních marketingových otázek, se kterými při strategickém plánování pracujeme.

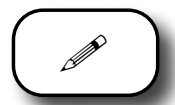

Tabulka 1: Základní otázka pro strategické plánování

\begin{tabular}{|l|l|}
\hline Extrapolace & Anticipace \\
\hline 1. Kde jsme nyní? & 1. Kam směřujeme? \\
\hline 2. Kam směřujeme? & 2. Kde jsme nyní? \\
\hline 3. Jak se tam dostaneme? & 3. Jak se tam dostaneme? \\
\hline 4. Jak poznáme, že jsme se tam dostali? & 4. Jak poznáme, že jsme se tam dostali? \\
\hline
\end{tabular}

Metoda čtyř kroků má následující body: diagnózu současného stavu (kde jsme nyní?), vizi rozvoje (kam směřujeme?), způsob realizace našeho záměru (jak se tam dostaneme?) a nakonec jejich evaluace (jak poznáme, že jsme se tam dostali?).

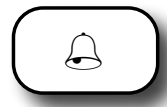

Samožrejmě v praxi zejména při dnes již běžné týmové práci při přípravě a inovaci strategického plánu školy se budeme setkávat s elementy obou postupů.

V publikaci Eger, a kol. (2002) jsme to s inspirací dle různých relevantních zdrojů rozpracovali následovně:

\section{Plánování z budoucnosti}

Startovním bodem procesu je vytvoření vize. Následně se vytvářejí strategické cile, které je potřebné splnit pro jeji dosažení. Ilustrativně to vypadá následovně: 


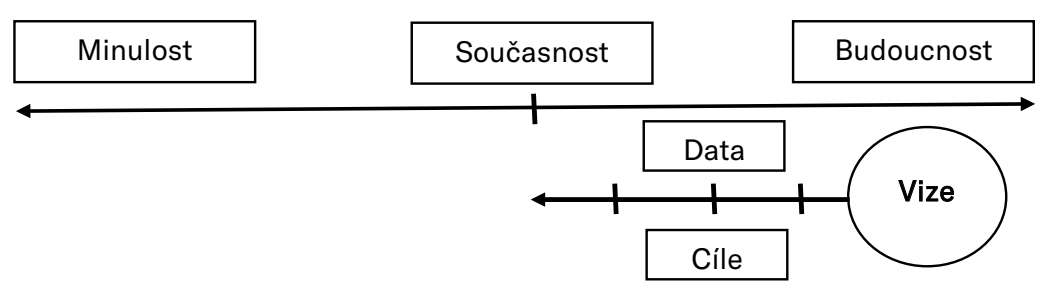

Obrázek 5: Schéma plánování z budoucnosti

\section{Plánování v krocích}

Základem je systematické dopisování do existujicího víceletého plánu (př. třiletý plán). Systematicky se aktualizuje v tom samém časovém rozsahu např. na začátku každého školního roku.

Tabulka 2: Plánování v krocích

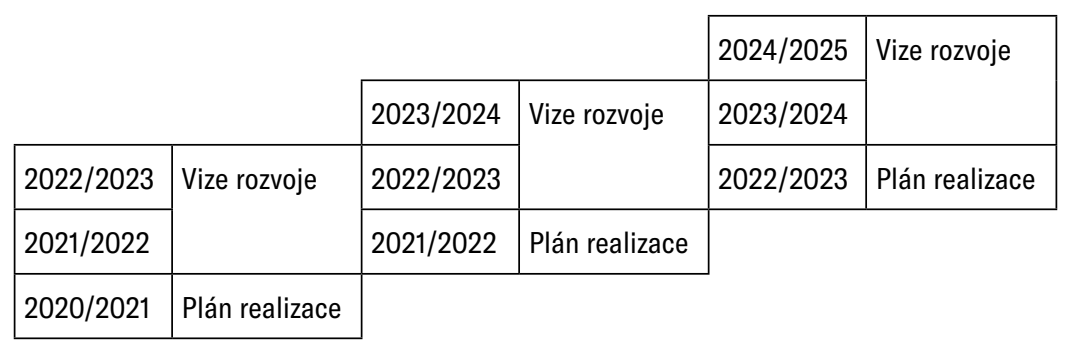

\section{! Základní schéma strategie plánování rozvoje školy}

Na závěr této důležité vstupní části uvedeme kličový bod. Můžeme ho označit jako „strategie strategie“.

Výsledné schéma aplikuje odborníky doporučované postupy, které se ovšem často liší v různých krocích. Smyslem je, aby také bylo stručné a jasně přehledné tak, aby sloužilo svému účelu. Analyzovali jsme větší množství doporučených postupů od klasických marketingových (např. Kotler, 2001; Majaro, 1996; Payne, 1996) přes aplikační z oblasti marketingu škol (kam radíme pojetí Světlíka, 1996 nebo Jakubíkové, 1998) až po postupy vyloženě spojené s managementem školy (Elsner, 2001; Everard \& Morris, 1996) či rízením kvality ve škole (Murgatroyd \& Morgan, 1994; Nezvalová, 2002). Na základě této analýzy, ale i zkušeností z praxe, které jsme získali z poradenské činnosti a z kurzů pro management škol, jsme prezentovali (Eger a kol. 
2002) následující přehledné schéma (obrázek 6), které je stále platné. ${ }^{31}$

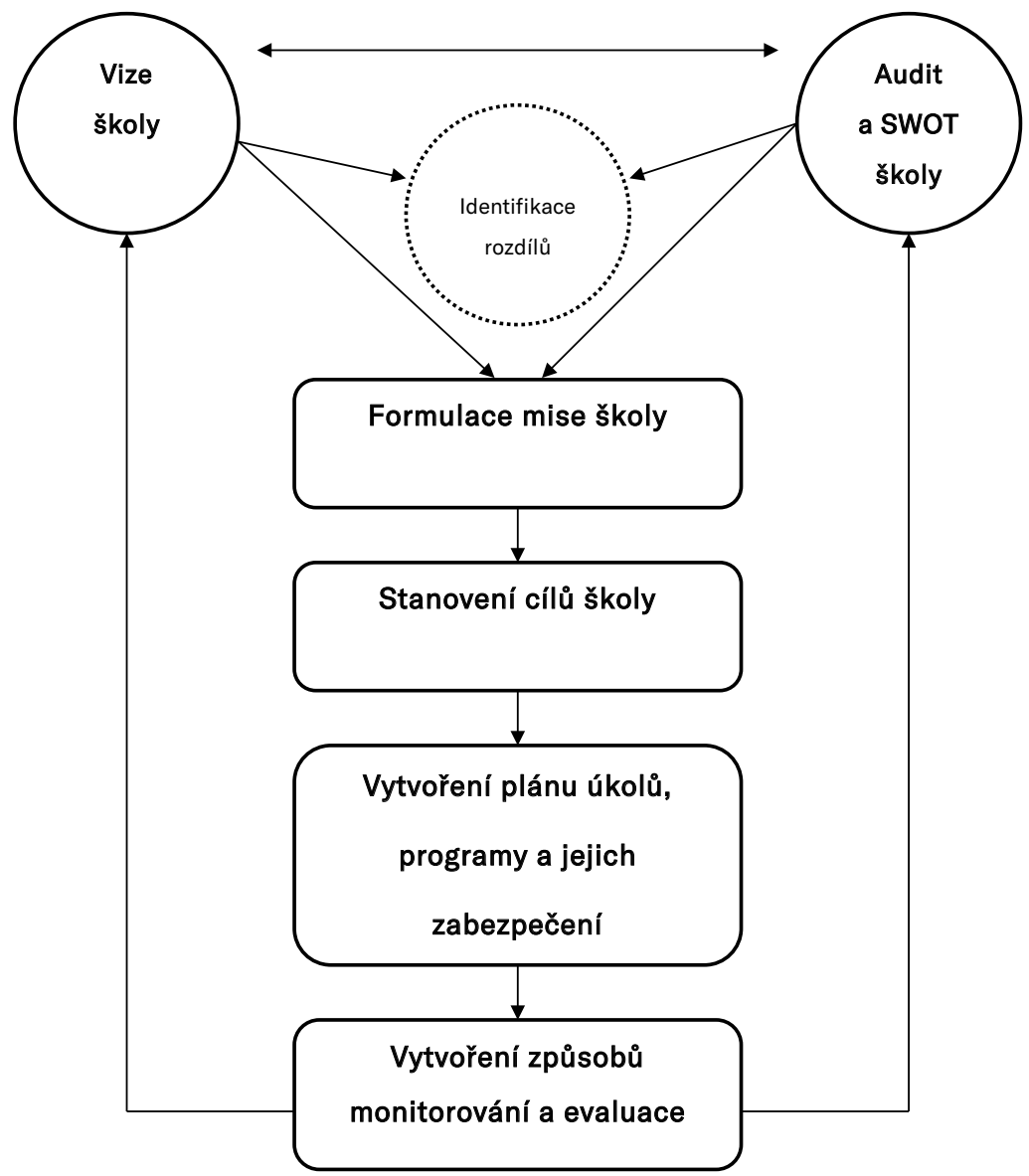

Obrázek 6: Schéma procesu strategického plánování rozvoje školy

Stručný popis a námět pro praxi:

1. Výchozím bodem je představa o budoucnosti a poznání současného stavu. Obojí se v praxi často realizuje současně a tím dochází

${ }^{31}$ Schéma je v souladu i s novějšimi publikacemi Jakubíkové (2008), Světlíka (2009) nebo Pisoňové a kol. (2014). Shodně i nová publikace k marketingu škol, Lockhart (2016a). 
k propojování přistupů, které popisuje Elsner (2001). Odpovídáme na základní otázky: Kam směřujeme? a Kde jsme nyní?

2. Oba vstupní body slouží pro poznání a popis rozdílů mezi současným a požadovaným stavem ${ }^{32}$, tj. pro identifikaci tzv. "děr" (také problémů, rozdilů, ale i príležitostí).

3. Misi školy považujeme za vrchol strategického plánu a je skutečně nesmírně důležitá v marketingu školy, otázka: proč existujeme?

4. Stanovení strategických cílů je základem pro dalši postup, otázka: čeho chceme dosáhnout? ${ }^{33}$

5. Při vytváření dílčích plánů potom použijeme hvězdu otázek: Proč, co, kde, kdy, jak a kdo? A nezapomeneme na otázku: Za kolik?

6. Celý systém se uzavírá do kruhu monitorováním a evaluací. Porovnáváme výkony ${ }^{34}$ a cile. Jak se dozvíme, že jsme dosáhli plánované cíle? Výstupy z této části jsou po nás také požadovány ve výroční zprávě školy a samozřejmě zřizovatelem a Čšl.

\section{!}

Smyslem rozvojového nebo strategického plánu školy je vytvoření přehledu a priorit aktivit školy v kontextu národní vzdělávací politiky a lokální politiky za účelem poskytnutí realistické strategie pro efektivní řizení školy. Plán musí být orientován na zajištění kvality vzdělávací služby pro žáky či studenty. (podle Brent \& Ellison, 1992)

\section{Strategický plán školy se rozpracovává $v$ ročních plánech a případně v akčních plánech či plánech jednotlivých projektů apod.}

Pro úspěšné implementování marketingové strategie musí vedení škol znát, jak aplikovat základy marketingového řizení efektivně s přihlédnutím ke specifickým podmínkám školy, kterou říí (viz i Lockhart, 2016a).

\footnotetext{
${ }^{32}$ Již z názvu je patrné, že to také souvisí s managementem změn v organizaci, zde půjde o strategické změny. ${ }^{33}$ Použijeme dnes již běžně známé pravidlo SMART pro jasnou specifikaci cílů.

${ }^{34}$ I v oblasti školství si musíme zvyknout na tzv. KPIs = key performance indicators, tedy kličové indikátory výkonu. Samožrejmě řada z nich bude specifická, protože hlavní službou je vzdělávaci proces podle RVP a implementovaného ŠVP v kontextu podmínek konkrétni školy.
} 


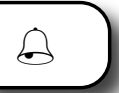

Ve starších publikacích Světlíka (1996) i Jakubíkové (1998) se v marketingu školy při volbě strategie zdůrazňuje tržní orientace, jež vychází z klasických marketingových strategií z firemního prostředí (srovnej s Kotler \& Keller, 2013). I když souhlasíme s využitím a aplikováním marketingu obecně, upozorňujeme na to, že "tvrdá“ tržní orientace v našem školství je diskutabilní a trh vzdělávacích služeb je a bude ovlivňován obcemi, kraji, státem atd. a to i u soukromých škol. Stejně tak se tato ostrá orientace na trh neobjevuje $v$ některých zahraničních publikacích, což koresponduje $s$ naším názorem. Podobně Lockhart (2016a) ve své publikaci několikrát zmiňuje, že je v USA rozdíl mezi školami, které dostávají veřejnou podporu a soukromými subjekty. Nicméně, pro uvedené odlišné subjekty, zejména při usilování o získání žáků = zákazníků a dodatečných i sponzorských zdrojů, poměrně jednoznačně aplikuje varianty klasických základních marketingových strategii. Proto si je také stručně pripomeneme.

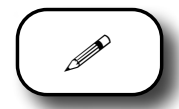

- Strategie pronikání - získávání většího počtu studentů pro existující studijní programy.

- Strategie rozvoje vzdělávacího programu - škola vytváři nové studijní programy nebo jejich zaměření a ty $v$ důsledku změn v prostředí nabízi svým potenciálním zákazníkům.

- Strategie rozvoje trhu - existující studijní programy jsou nabízeny novým zákazníkủm.

- Strategie diverzifikace - tvorba nových programů a zaměření na nové trhy.

\subsection{Klíčové oblasti strategického plánu školy}

\section{Úvod}

Již v naší publikaci z roku 2002 jsme uvedli, že se jistě se najdou čtenáři, kteři očekávají, že bude následovat doslovná kuchařka obsahu strategického plánu pro rozvoj školy. To by ovšem nebylo správné a není to ani možné vzhledem k mnoha specifikům konkrétní školy. Došlo by i k popření procesu plánování, a predevším by to i mohlo omezit vaši tvưrči činnost a nutnou a potřebnou týmovou spolupráci při utváření rozvojového plánu školy. 
Naopak považujeme za vhodné uveřejnění následujících kritérií a schématu rozvojového plánu. I toto schéma, které koresponduje se strategickým postupem, by v obsahu střední části mělo být jen možnou ukázkou a ne dogmatem. Kličové oblasti a kličové podpůrné prvky musite stanovit sami podle konkrétních podmínek školy.

\section{Kritéria pro efektivní plánování}

Předkládáme doporučený kontrolní list (dle Brent \& Ellison, 1992). Jestliže chceme ve škole plánovat, musíme zajistit:

1. Potřebné vhodné informace, a to jak z externích, tak i z interních zdrojů.

2. Kanály komunikace, které budou podávat nezkreslené informace ve všech směrech.

3. Zaměstnanci na všech úrovních jsou zahrnuti do projektu a jeho cílů.

4. Úroveň plánování musí být zřejmá tomu, kdo plánuje poradu. Je neefektivní míchat strategickou úroveň s taktickou a s operačními úkoly. Je to obtižné pro administrativu a zaměření pozornosti. (Pozor, toto je dle našich zkušeností v praxi velmi častá chyba!)

5. Řada oblastí práce ve škole je řešitelná efektivní týmovou spoluprací, ale jedině tehdy, pokud je známo, co je požadováno - jsou jasné cíle.

6. Proces evaluace je tvořen během procesu plánování, je to lepší, než jeho „uvaření“ později.

\section{(-) Námět pro praxi}

Pro vlastní obsah plánu doporučují např. Brent a Ellison tzv. „holistické“ neboli celostní pojetí. Rozvojový plán poskytuje mechanismus definování cílů školy a jejich aplikování v efektivním vzdělávacím procesu.

Aktivity by měly být rozvedené do kličových oblastí, které reprezentuji školu z hlediska jejího hlavního účelu, a do oblastí, které podporuji či usnadňují efektivní činnosti pro klíčové oblasti.

To je např. prezentováno podle Brent a Ellison (1992) následujícím schématem (obrázek 7). 


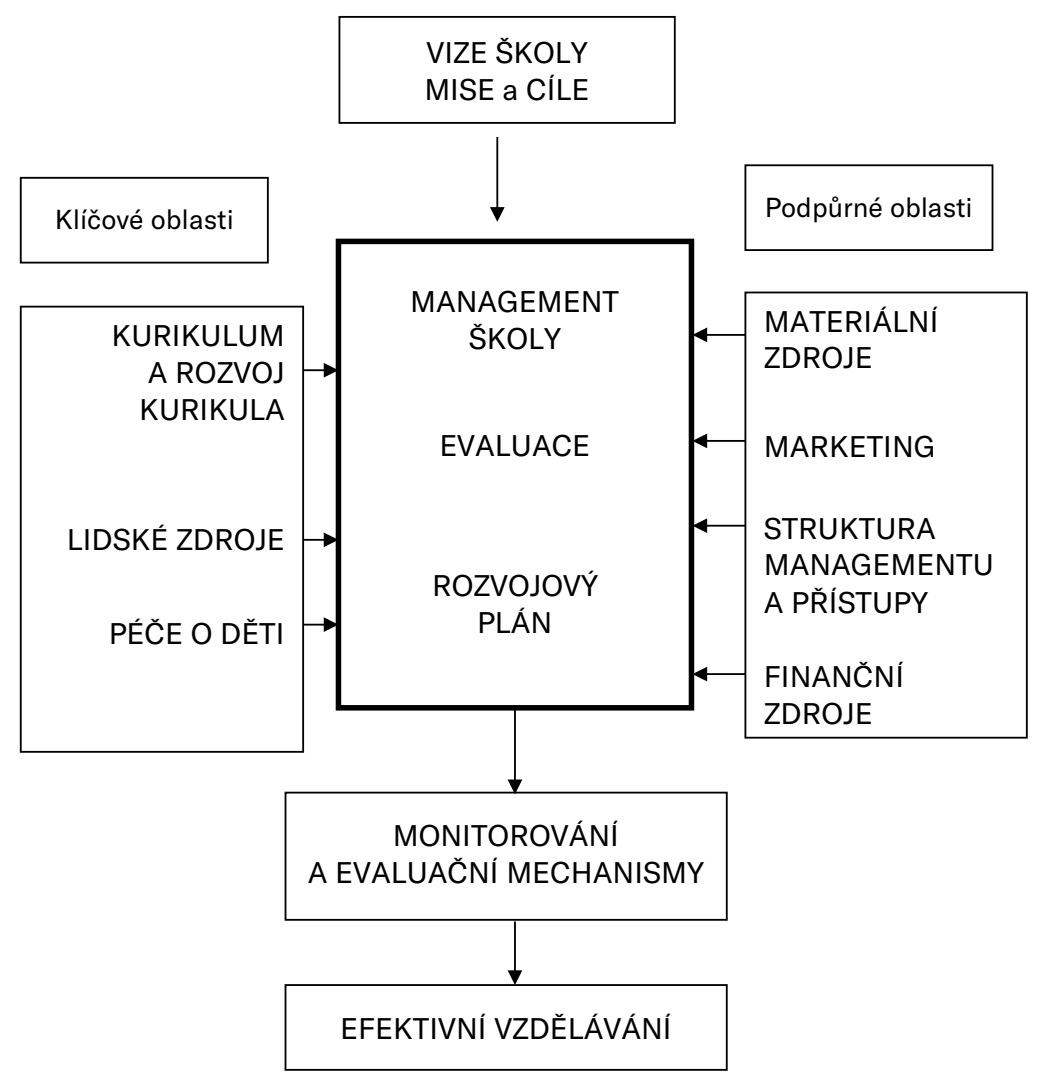

Obrázek 7: Schéma managementu rozvojového plánu školy (úprava Eger a kol., 2002)

\section{(:)}

Každá z uvedených dílčich oblastí bude mít dále svůj vlastní plán, který bude zaměřen na její rozvoj. Důležité je ovšem celostní pojetí a při plánování rozvoje jednotlivých oblastí vždy vycházíme $z$, ale i směřujeme, k rozvojovému plánu školy.

Zde se opět dostáváme k podstatné informaci. Musíme rozlišovat strategické plánování s horizontem 1-3 roky a delším. Taktické plánování se doporučuje pro horizont 3-18 měsíců a operativní plánování, které ve škole průběžně prováději všichni učitelé a je obvykle v horizontu pololetí. Doporučení: 
- Načrtněte si nástin struktury vlastního rozvojového plánu. Využijte předložené schéma a zachovejte vertikální linii. Doplňte prostřední horizontální linii o oblasti dle vašeho uvážení a dle konkrétních požadavků. ${ }^{35}$

- Opět pro využití v praxi uvádíme velmi vhodnou metodu, která je použitelná pro základní rozpracování plánu ve vybraných hlavních a podpůrných oblastech. Metoda se nazývá hvězda otázek a prebíráme ji v úpravě od autorek Elsner a Knafel (2000).

Tato jednoduchá metoda provází proces plánování a zaměřuje ho na hlavní aspekty, které jsou ve hvězdě (obrázek 8) zobrazeny šesti otázkami.

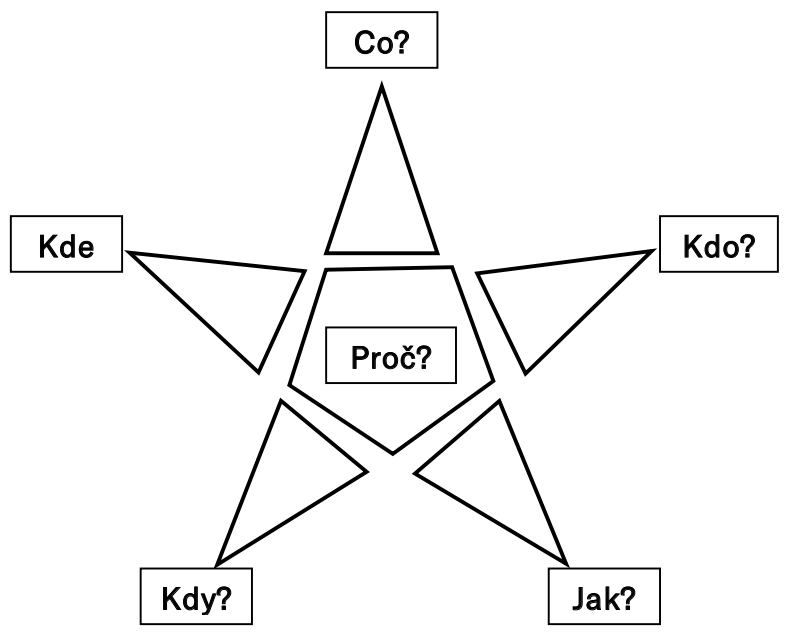

Obrázek 8: Hvězda otázek

\section{Otázka:}

- $\quad$ proč? - je směřována $\mathrm{k}$ cílům a účelu aktivity

- co? - úkoly, kterými se chceme zabývat

- $\quad$ kdo? - hlavní vykonavatel (odpovědná osoba) a spolupracovníci

- jak? - metody a techniky způsobu činnosti

- $\quad$ kdy? - konkrétní vymezení času pro realizaci

- $\quad k d e ?$ - místo akce

\footnotetext{
${ }^{35}$ Určitým námětem pro obsah plánu může být i dobře propracovaná Rukovět ČŠı. Tvořit rozvojový plán jen podle materiálu kontrolniho orgánu by ovšem bylo pošetilé.
} 


\section{?}

Výše uvedené otázky mohou mít modifikace podle potřeby. Např. otázka Kdo? se dá modifikovat na Pro koho?, Od koho?, S kým? Podobně otázka Kdy? se může změnit na: Od kdy?, Do kdy? Autorky upozorňují, že je chybné na otázku Kde?, odpovídat ve škole. Je vhodné lépe specifikovat místo.

Upozornění:

Ve hvězdě chybí jedna důležitá otázka: Za kolik? Nesmíme na ni při plánování zapomínat.

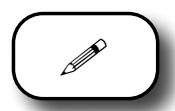

Schéma strategického plánovacího procesu (Kotler \& Keller, 2013) a obvyklé struktury marketingového plánu (dle Belch \& Belch, 2021), viz př́loha $A$.

Následovat bude kapitola věnovaná vizi, misi a auditu školy.

\section{? Kontrolní otázky a úkoly:}

- Proč potřebujeme ve škole strategické plánování, uved'te důvody.

- Kdo je odpovědný za strategické rízení?

- Jaký je doporučovaný postup při strategickém plánování?

- Které kličové a které podpůrné oblasti rozhodně nebudou v našem plánu chybět?

- Jaké úrovně plánování následuji po strategické?

\section{[Dd Literatura:}

Eger, L., Egerová, D., \& Jakubíková, D. (2002) Strategie rozvoje školy. Plzeň: Cechtuma.

Jakubíková, D. (2008). Strategický marketing. Praha: Grada.

Světlík, J. (2009). Marketingové řizení školy. Praha: Wolters Kluwer.

Pisoňová, M. a kol. (2014). Školský manažment pre študijné obory učitelstva a prípravu vedúcich pedagogických zamestnancov. Bratislava: Univerzita Komenského v Bratislave. Dostupné z: https://www.fedu.uniba.sk/file admin/pdf/Sucasti/Katedry/KP/KAPESO/Skolsky_manazment.pdf 
Jako alternativní je možné doporučit dokumenty a materiály z projektu NiDV (2016-2021) Strategické řízení a plánování ve školách a v územích. Dostupné z: https://projekty.nidv.cz/strategicke-rizeni 


\section{POSLÁNÍ, VIZE ŠKOLY A MARKETINGOVÝ AUDIT}

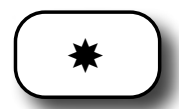

\section{Cíle:}

- Pochopit úlohu poslání školy a funkce mise pro vnitřní i vnější komunikaci.

- Získat náměty pro formulování vize školy.

- Seznámit se $\mathrm{s}$ marketingovým auditem a doporučením $\mathrm{k}$ jeho realizaci.

- Získat doporučení pro realizaci makro, mikro i vnitřni analýzy školy.

- Uvědomit si některé chyby, ke kterým docházi při realizaci marketingového auditu školy.

mise, vize školy, PEST analýza, Porterova analýza pěti sil, VRIO analýza, SWOT analýza, marketingový informační systém

Čas potřebný ke studiu základního textu kapitoly je cca 20 minut + možnost rozšírení o studium externích zdrojů $\mathrm{z}$ internetu.

\section{Úvod}

Formulování mise je jednou z etap strategického plánování. Někdy dochází ke směšování vize a mise, a proto si v úvodu kapitoly stručně zopakujme: vize je pohledem do budoucnosti a odpovídá na to, co chceme či jak by měla v budoucnu naše škola vypadat. Marketingový audit školy nám dává odpověd' na otázku: kde jsme nyní. $V$ rámci strategického plánování si také musíme odpovědět na důležitou otázku: proč existujeme. Žretelná, jasná a stručná odpověd' je misí - posláním školy. Toto poslání by rozhodně nemělo být formální 
záležitostí, ale podobně jako vize vědomým faktem, se kterým se identifikují zúčastnění.

\subsection{Poslání školy}

$\square$ Stručná, ale výstižná definice mise:

\section{“Jsou hodnoty a dlouhodobé cíle organizace obvykle vyjádřené jako prohlášení.“" (Oldroyd a kol., 1996)}

V V literatuře můžeme najít dva odlišné přístupy formulace mise:

První doporučuje, aby toto prohlášení (deklarace) bylo krátké a stručné do 100 slov. Někdy je doporučováno i využití sloganu.

Druhý přístup mluví o jedné až dvou stranách textu. Tento typ odpovídá formulaci v bodech nebo použití tzv. marketingového memoranda, o kterém se ještě dále zmíníme.

V ČR se problematikou mise školy již zabýval Světlík (1996, s. 176), který uvedl: „Vedení školy by mělo zahájit proces stanovení cílů definováním svého poslání, tj. dlouhodobým pohledem školy na to co chce a kam miří. Poslání školy je prohlášení trvalého charakteru, které poskytuje pohled na současné a budouci aktivity školy, jeji hodnoty a na to, co ji odlišuje od jejích konkurentů. Mělo by poskytnout pochopení směru a cíle školy. Formulování poslání by mělo být unikátní pro každou vzdělávací instituci, protože každá funguje v jiném prostředí, má jiný pedagogický sbor, předmět činnosti, jiné cíle." Výše uvedené tvrzení ale směšuje dlouhodobý pohled (spiše vize) s poskytováním základních hodnot (spiše mise). Ano, se spojením obojího se v praxi můžeme setkat u řady organizaci, my si ale ukážeme odděleně formulaci těchto základních „stavebních kamenů“ strategie organizace tak, jak jsme to již prezentovali dríve (Eger, a kol., 2002).

$K$ odlišení vize (pohledu zaměřeného na budoucnost) a mise (prohlášení o poslání organizace) nejlépe poslouží, pokud hledáme odpovědi na základní otázky: 


\section{!}

Co chceme? (Kam kráčíme?) - vize

Proč existujeme? - mise

Uvedené rozdělení odpovídá i názoru anglických odborníků (Everard \& Morris, 1996) a my se k němu přikláníme.

\section{!}

\section{Dvě funkce mise}

Pro stanovení mise existují různá doporučení. Elsner (1999) z jejich analýzy vyvozuje, že mise má dvě základní funkce:

- Vnitřní, která má informační charakter a je zaměřena na působení dovnitř organizace.

- Vnější, která také informuje, ale hlavně udává (zobrazuje) význam a integrování ostatních (partnerů školy) pro realizaci uvedené mise.

\subsection{Formulace poslání školy}

Formulování mise je důležitým úkolem managementu školy. Důležitá není jen mise, ale také proces jejího formulování (Elsner, 1999). Autorka tím myslí organizování diskusí, obhajování názorů, polemiku i vedení sporů, přemýšlení, reflexi, konzultace atd., prostě vše, co zajistí, že celé společenství si také $v$ tomto procesu uvědomí potřebu a nezbytnost mise.

"Dobře stanovené poslání poskytuje všem zaměstnancům možnost sdílet společné hodnoty, cíle a přiležitosti.“" (Kotler, 2001) Je zde tedy úzké propojení s kulturou organizace (viz dále v publikaci), s vizí i její strategií.

(ن)

Mise jako marketingové memorandum

Již jsme uvedli, že existuje i širší pojetí mise. Ve starším vydání publikace Marketing management (Kotler, 2001) byl uveden velmi praktický následující návod. Dodáváme jen, že je uveden v souvislosti s pojednáním o organizační kultuře a uvádíme ho v aplikaci zaměřené na oblast školství. 


\section{? Proč existujeme a co představujeme?}

Chcete-li formulovat poslání vaší školy, můžete postupovat následujícím způsobem.

Začněte prohlášením: „Naše škola poskytuje tyto služby .....

Potom si několikrát za sebou položte otázku: „K čemu je to dobré?“ Po několika otázkách dojdete $\mathrm{k}$ výchozí podobě poslání vaši školy. Například místo „Vzděláváme nebo poskytujeme středoškolské vzděláni“ můžete dojít k formulaci „Přispíváme $\mathrm{k}$ lepšímu uplatnění našich absolventů na trhu práce poskytováním kvalitního vzdělávaciho programu, zaměřeného na ....".

Identifikace základních hodnot školy, které jsou ve škole trvale respektovány, vyžaduje:

1. Usilovně a otevřeně definovat nejméně šest hodnot, které jsou pro vaši školu nezastupitelné.

2. Zamyslet se nad tím, zda jste nezaměnili základní hodnoty (které se nemění) s manažerskými praktikami, obchodními strategiemi nebo kulturními normami (u všech může dojít ke změně).

3. U každé hodnoty si položit otázku: „Dojde-li k takové změně okolností, že dodržování hodnoty bude pro školu problematické, bude nutné přistoupit k její změně?"

4. Odpovíte-li „ano“, nejedná se o základní hodnotu školy a je třeba ji vyřadit. Zvažte, dojde-li ke změně podmínek a dodržování hodnot je problematické, škola by neměla měnit své základní hodnoty, ale raději změnit trh.“

Použijte ještě pohled ze strany rozhodujícich cílových skupin včetně partnerů školy (Everard, Morris, \& Wilson, 2004). S vědomím toho, co je váš hlavní vzdělávací program, jaké jsou jejich možná očekávání ve vztahu ke škole? Jaké hodnoty pravděpodobně od školy očekávají? Zvažte, jak se mohou lišit priority hodnot pohledem jednotlivých skupin?

Jakubíková (2008) i Světlík (2009) upozorňuji na to, že poslání by také mělo vycházet z historie organizace, samozřejmě respektovat faktory vnějšího prostředí, ale i zdroje organizace. Zejména pro soukromé subjekty budou významným i preference vlastníků, pro veřejné školy tedy zřizovatelů, a to vše $v$ našem prípadě na pozadí základního účelu existence školy ve společnosti. 
Zde je pro dokreslení vhodné uvést příklady několika krátkých formulací mise, či jejích součástí, které jistě budou vyhovovat uvedeným požadavkům. ${ }^{36}$

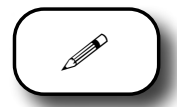

„Vzděláváme děti.“

"Připravujeme děti pro budoucí život ve společnosti.“"

„Rozvíjíme osobnost žáka prostrednictvím vzděláváni.“"

"Jsme škola, která vzdělává a rozviji mladé lidi."

- Přiklad mise s užitím bodů:

Jsme škola, která:

- poskytuje dětem základní vzdělání,

- $\quad$ pomáhá všem dětem v rozvoji jejich talentu,

- zajištuje rovnost přiležitostí v bezpečném prostředí,

- $\quad$ podporuje duch partnerství mezi žáky a učiteli, rodiči a školou, komunitou a školou,

- orientuje děti na život v občanské společnosti, př́pravu na práci a celoživotní vzdělávání.

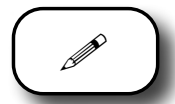

Světlík (2009, s. 119) přichází s požadavkem spíše širši formulace a uvádí: „Poslání by mělo obsahovat především následující komponenty:

- kdo jsou zákazníci školy,

- co je hlavní aktivitou školy a jejím hlavním cílem,

- kde škola působí,

- filozofii školy, tj. základní hodnoty a priority a

- $\quad$ silu a výhody ve vztahu ke konkurenci.“"

Doporučuje formulaci zaměřit spiše na zákazníky školy než na nabízený vzdělávací program. ${ }^{37,38}$

\footnotetext{
${ }^{36}$ Everard, Morris, \& Wilson (2004) uváději, že obecně do základů mise školy patři napřiklad: vzděláváme děti, připravujeme děti pro život, občanstvi a práci...

${ }^{37}$ Zvažte: DiMartino a Jessen (2018) propojuji dobře formulovanou misi školy s komunikací školy jako značky.

${ }^{38}$ Velmi zajimavě má své posláni (přiklad) formulované Univerzita v Bayreuthu, najděte si na internetu, je to ale pod Our Vision = jedná se vlastně o propojení vize a mise.
} 
Poslání též pomáhá akceptovat základní hodnoty, zaměřuje pozornost pedagogického sboru na kličové cíle a je i motivačním faktorem. Identifikace s ním (učitelů, ostatních pracovníků školy i studentů) způsobuje, že se odráží v každodenní činnosti a funguje jako kompas v orientaci naší práce.

Mise je také elementem image školy a měla by být jedenkrát ročně podrobena reflexi sborem školy. Musí se odrážet $v$ aktivitách ředitele i ostatních pracovníků. Musí být prezentována na setkáních, v dokumentech školy a doporučuje se ji zveřejnit na důstojném místě při vstupu do školy.

(:)

„Pokud je poslání definováno přiliš vágně, úzce nebo naopak príliš široce, je obvykle formální a mijí se účinkem.“ (Světlík, 2009, s. 119)

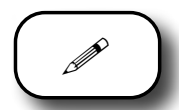

To, jestli je mise dobře formulovaná, může vedoucí pracovník školy zjistit i následující aktivitou, kterou doporučuje Lockhart (2016a): Zeptejte se lidí ve škole: co jsi tento týden vykonal-a pro naplňování poslání naší školy? Jestliže více dotazovaných nedokáže odpovědět, potom pravděpodobně vaše mise nemá požadovaný efekt.

Nakonec nezapomeňme na to, že poslání se v průběhu času může měnit s tím, jak například škola využivá nové přiležitosti nebo reaguje na změněné podmínky ve společnosti (srovnej s Kotler \& Keler, 2013).

\section{? Kontrolní otázky a úkoly:}

- Vysvětlete účel poslání - mise organizace.

- Jak chápete rozdíl mezi vizi a misí?

- Jaké jsou dvě základní funkce poslání?

- Proč se doporučuje věnovat pozornost komunikaci poslání?

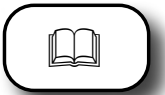

Literatura:

Kotler, P., \& Keller, K. L. (2013). Marketing management. Praha: Grada. Světlík, J. (2009). Marketingové řizení školy. Praha: Wolters Kluwer. 


\subsection{Vize školy}

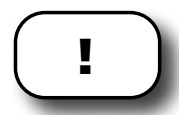

Vize je podle Elsner (1999) obecně jedním z důležitých termínů v teorii a praxi rízeni:

- $\quad v$ teorii $-\mathrm{z}$ hlediska stále většího důrazu, který je věnován prognostice v projektování organizace (metoda plánování z budoucnosti),

- $\quad v$ praxi - protože otázky vize jsou standardní součástí konkurzů na ředitele škol.

Stručně ji můžeme definovat následovně:

\section{$\square$}

„Vize je představa úspěšné budoucnosti organizace, která vychází ze základních hodnot nebo filosofie, se kterou jsou spojeny cíle a plány organizace.“" (Oldroyd a kol., 1996)

$\checkmark$ teorii a praxi řizení je vize definovaná jako pozitivní zobrazení budoucnosti organizace, které je vytvořené na základě uznávaných hodnot a idejí, ze kterých se vyvozují cíle a plány činnosti. Pro využití vize organizace je důležité, aby byla pochopena a sdílena zaměstnanci.

Vize se tedy stává sdílenou představou o podstatných záměrech. Důležité je, že je spojena s očekáváním a usilováním o vše, co je spojeno s organizací. Je to základní záměr, který by měla organizace nabizet nejdřive. Ten se potom stává výzvou pro všechny, kteři jsou nějakým způsobem spojeni se školou. To znamená, že přesahuje vnitřní prostředí školy. Na druhé straně vize organizace by také měla odpovídat reálné situaci, schopnostem a možnostem organizace (Jakubíková, 2008). ${ }^{39}$

Jakubíková (2001) uvádí: „dobrá vize dokáže inspirovat zaměstnance školy k samostatnému a tvořivému jednáni“. Tento fakt jistě stojí za to, abychom věnovali pozornost vytváření vize školy a prosazovali její sdílení ve škole.

\footnotetext{
${ }^{39} \mathrm{~V}$ tom se neshoduje s pedagogickým přistupem Chvála (2018) z publikace Na naši škole nám záleží. Ten uvedená praktická doporučeni postavil na kritérích ČŠI (2017/2018). To sice na jedné straně může být přinosné pro podprůměrné školy a začinajici ředitele = maji se čeho chytit, a je to přeci podle přáni Čšı! Na druhé straně to při přehnané aplikaci povede $\mathrm{k}$,jednotné škole“, kde se abstrahuje od kontextu a podmínek školy, ale také to může potlačit laterálni myšleni a kreativni a neobvyklé prístupy inovativních škol.
} 
Pojetí vize v sobě zahrnuje dvě komponenty: filozofii, kterou se bude ubírat organizace a konkrétní představy (Collins \& Porras 1991 in Murgatroyd \& Morgan, 1994).

\section{Vize reprezentuje aspirace školy a sumarizuje, čeho by chtěla škola dosáhnout.}

Vize je také důležitým pojmem z oblasti TQM. Přitom poznatky z Total Quality Managementu se dnes hlavně pod pojmem řizení kvality začínají využívat i v regionálních školách. Praxe posledních 15 let v ČR např́klad ukázala, že s realizaci kutikulární reformy (Eger, 2006) při poměrně velké autonomii škol, musely managementy škol se svými učitelskými sbory věnovat více pozornosti strategickému plánování a nutně i vytvoření či inovace vizí škol. V současné době můžeme konstatovat, že naše školství je téměř v neustálé situaci řizení změn ve škole. Některé se týkají jen dílčích oblastí ve škole, některé jsou ale tak významné (často vyvolané závaznými dokumenty reprezentujícími státní politiku v oblasti vzdělávání), že si vynucují zásahy do vizí škol v kratším horizontu, než se u vize organizace obecně předpokládá. ${ }^{40}$

S vizí jako s obrazem budoucnosti je spojena otázka časového horizontu. Pro školy se obecně doporučuje horizont několika let, ale viz poznámka výše a změny ve společnosti a tlak na řizení změn, jež se dotýkají i strategií škol v kratších horizontech. Otázkou je, zda tato dynamika se ve školství již nestane běžným procesem?

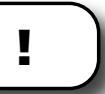

Vize má tři funkce (podle Murgatroyd \& Morgan, 1994):

1. Za prvé je inspirací. Každý ve škole by měl být seznámen s vizí a měl by ji umět interpretovat. Vize by se měla stát základem pro povzbuzení, rozvoj, inspiraci, možnost uplatnění učitelů... je hybnou silou nejen pro jednotlivce, ale pro celou školu. Musíme zdůraznit, že vize musí zahrnovat i žáky a případně dalši spolupracující subjekty. Položme si otázku: je vize sdílena žáky?

2. Za druhé je vize základním kamenem pro rozhodování. Každá činnost ve škole by měla být zvažována v souvislosti s vizí. Jak k ní přispivá naše činnost? Je ve shodě? Přibližuje naše činnost vizi realitě?

\footnotetext{
${ }^{40}$ Viz napřiklad změny v RVP od roku 2021, v minulém roce změny i distančni výuce v důsledku COVID-19, aj.
} 


\section{Za třetí vize umožňuje všem uvnitř i vně školy najít společné body,}

které vedou ke zlepšení kvality. „Vize je nástrojem pro týmovou práci“ (tamtéž).

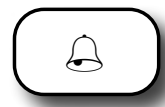

Vize je jasně definovaný, realistický a věrohodný obraz toho, čeho chce škola $v$ budoucnosti dosáhnout. Musí odrážet potřeby zákazníků a také kroky (postupy) vedoucí ke zlepšení současného stavu.

Vize je ovlivněna naší současnou situací, ale při její formulaci si musíme dát pozor na naši svázanost $s$ momentálně důležitými věcmi, které nám někdy brání v koncentraci na priority budoucnosti. Vize musí být formulovaná s odstupem od každodenních záležitostí.

Doporučení: vlastní formulace je také orientována pozitivně. Nepouživáme negativní formulaci s problémy apod.

Řizení vize neboli předvídání budoucnosti je složitým procesem, a to jak na úrovni školy, tak na úrovni systému vzdělávání. Jde nejenom o syntézu pohledů a tvưrčí vyobrazení, ale také odborné zhodnocení trendů, které mají vliv na budoucnost organizace, a to na úrovni vnitřního prostředí, mikroprostředí a makroprostředí školy. ${ }^{41}$

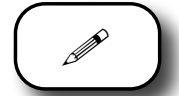

Námět pro praxi

Při tvorbě vize se pro ředitele školy doporučuji následující kroky:

1. Nejdřive musíte ve škole přesvědčit o významu vize. Učitelé, studenti i ostatní pracovníci by měli chápat důležitost vize.

2. Tvoření vize předpokládá týmovou práci. Zapojte jednotlivce, malé týmy, učitele, žáky i rodiče a případně ostatní partnery školy. Vybírejte společné významy z pracovních návrhů. (zde je vhodné použít metody brainstormingu, panelovou diskusi apod.)

3. Tvorba vize by měla být společným dílem. Mělo by se vycházet z vizí ostatních, aby bylo dosaženo toho, že i ostatní se ztotožní s naši vizí.

4. Vytvořte skupinu, která provede shrnutí podkladů a vytvoři návrh, jenž bude opět posuzován.

${ }^{41} \mathrm{~V}$ podkapitole zaměřené na marketingový audit školy budeme prezentovat základní doporučované nástroje pro analýzu současného stavu na uvedených třech úrovnich, dále viz např. Světlík (2016) nebo Kotler a Keller (2013). 
(ن)

Ještě jeden námět z učebnice školského managementu z Anglie (Everard \& Morris, 1996). $V$ cestě, jak tvořit vizi, nám pomůže, odpovíme-li si na následující otázky:

- Kam chceme dojit?

nebo

- Kde skončíme, necháme-li věci plynout tak, jak jsou nyní?

$\odot$ Zvažte:

- Vizionáři - řídí prostřednictvím vize.

- Sdělení vize znamená sdělení smyslu vize.

- Řizení vize není o tom, jak nahradit nedostatky.

- Rozmyslete si: je vize souhrnem cílů nebo idejí!

- Hlavním problémem není utvoření vize, ale dosažení jejího sdílení. To je nejtěžší!

- $\quad$ K realizaci vize slouží víceleté plánování.

- Jestliže se vize nestane naším údělem a nebude rozpracovaná do úkolů a ty do časových údajů, pak je to problém, který pravděpodobně znemožní její realizaci.

- Problémem je, že ve školství se použivají zejména plány s krátkým horizontem.

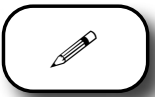

Př́klady vize školy:

Ukázka kratší verze vize školy:

Naše škola se stane místem, kam bude každé dítě rádo chodit, kde získá základní znalosti a kde se rodiče a jiní členové komunity budou moci zapojit do vzdělávacích programů vedoucích $k$ rozvoji jejich dětí.

Př́klad školy z Anglie:

Na naši školu budou všichni učitelé a žáci pyšní a rodiče a ostatní členové komunity ji budou pravidelně navštěvovat a podporovat.

Ne všichni žáci budou ve všech oblastech dosahovat vynikajicích výsledků, ale jsme přesvědčeni o tom, že většina dětí může být lepši a může se do školy těšit. 
Různými cestami zapojíme rodiče do činnosti školy a budeme spolupracovat $s$ jinými organizacemi a firmami, které přispěji ke zlepšení školy. Vytvoříme partnerskou spolupráci s místní samosprávou a komunitou.

Náš vzdělávací program a výuka budou odrážet potřeby a zájmy všech dětí a budou provázeny vysokým očekáváním výsledků a realizovány v s velkým zaujetím.

Př́klad nadčasové vize Open University:

Dát univerzitní vzdělání všem, bez ohledu na věk, místo a předchozí vzdělání.

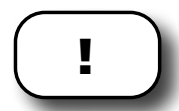

\section{Vize a audit školy jsou základními stavebními kameny, které použivá- me, když chceme řidit změnu školy.}

\section{Každá strategie změny je tak dobrá, jak je dobrá její komunikace. ${ }^{42}$}

Např́ílad Jakubíková (2008, s. 20) v této souvislosti zdůrazňuje, že „vize vyžaduje, aby každý pochopil a přijal roli při její realizaci..... Zdůrazňuje, že jádrem vize je „výsledek“, kterého má být dosaženo v zájmu zákazníka (opět zvažte, kdo všechno je „zákazník“ školy?).

Pro řízení změn ve škole platí obecné zásady a zkušenosti z oblasti managementu firem (viz např. Armstrong, 2007; Řehoř, 2016). Ty říkají, že výsledky projektů změn jsou často nedostatečné a hlavní bariéry jsou spatřovány ve firemní kultuře a interní komunikaci.

Managementu změn ve školství se věnovala např. Prášilová (2000), která ve svém doporučeném postupu zdůraznila následující:

- Tlak na provedení změny (nutnost transformace školy do adaptivního, otevřeného a učiciho se systému).

- Kompetentní management školy (má také jasnou vizi).

\footnotetext{
${ }^{42}$ Poznámka: Zájemci o hlubši studium se mohou seznámit s výsledky studie, která zkoumala vztah učitelů ke změnám (Zelinová, 1998 a Eger a Egerová, 1998 in Eger a kol. 1998) a uvědomit si, že se při managementu změny setkaji se čtyřmi skupinami lidí: zaskočeni změnami, obrněni proti změnám, fandové změn a učici se, pro které jsou typické určité reakce na změny. Podobně Armstrong (2007).
} 
Proces změny zařadila do následujících „klasických“ fází: plánování, zpracování realizačního projektu, implementace, hodnocení výsledků implementace. ${ }^{43}$

Vize $v$ sobě tedy zahrnuje představu 0 možných změnách, které povedou k žádoucímu budoucímu stavu. Než je budeme v praxi provádět, musíme být přesvědčeni o tom, že se s naši vizí ztotožňuji ostatní. Ostatně stav nesouladu v této oblasti je častou přičinou neúspěchu při zavádění změn v našich školách. Elsner (1999) dokonce mluví o nutném získání alespoň minimální podpory hned na počátku - při představení změny.

Vize bez následné aktivity pro její naplnění je jen snem. Vytváření vize, získání ostatních pro jeji realizaci, a nakonec i její naplňování, je základní úlohou ředitele či ředitelky školy jako leadera (viz i Fullan a kol. 2013, Lockhardt, 2016a). ${ }^{44}$

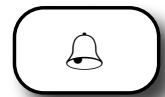

Zbývá otázka kontroly vize. Každá vize by měla být stejně jako ostatní strategické dokumenty např. jedenkrát ročně podrobena určité supervizi. Ve škole to může být činěno v souvislosti s vytvářením výroční zprávy školy. Opět by to ovšem neměla být činnost pouze vedení školy, ale je nutné zapojit sbor a ostatni partnery školy.

\section{Kontrolní otázky a úkoly:}

- Vysvětlete účel vize školy.

- Jaké jsou tři základní funkce vize?

- Proč se doporučuje věnovat pozornost společnému tvoření vize školy?

\subsection{Marketingový audit}

Úvod

Marketingový audit školy je důležitou součástí strategického či rozvojového plánu. Považujeme jej společně s vizí a posláním školy za základní stavební kameny strategie rozvoje školy.

\footnotetext{
${ }^{43}$ Klasický Lewinův a Kotterův model viz Řehoř (2016). Podobně i nástroj pro řizení změny PDCA (Plan-Do-Check-Act).

${ }^{44}$ Zajímavým př́kladem je škola v sociálně vyloučené lokalitě v Trmicích, když se mluví o úspěších po nástupu nové ředitelky, zmiňuje se: vize, nový přístup v komunikaci a podpoře učitelů, zcela jiná komunikace s rodiči, zaměření na úspěch žáků, řada zajímavých aktivit, ale i komunikace s absolventy...
} 
Na druhou stranu zde také platí, že než formálně zpracovaný audit „do šuplíku“ ředitele či ředitelky školy, tak raději žádný. Interně zpracovaný audit školy je náročnou týmovou praci ${ }^{45}$ (externí varianta je pro školy z finančních, ale i vnitřních potřebných komunikačních důvodů ne zcela výhodná). ${ }^{46}$ Někteří experti (např. Chvál, 2018) doporučuji se držet Rukověti (př. 2017/2018), kterou vydává ČŠl. V našem prípadě ale budeme vycházet ze zkušeností z marketingu (Eger a kol. 2002; Jakubíková, 2001; Světlík, 2009) a aplikovaně využívat standardní postupy a nástroje.

Je také pravdou, že pryč je doba počátku devadesátých let, kdy jsme s podporou zahraničních expertů objevovali napřiklad SWOT analýzu a učili se ji v její základní verzi aplikovat pro školství. Protože bylo stále více zřejmé, jak důležité je i vnější měnící se prostředí škol, začala se později aplikovat PEST analýza (a její různá rozšíření) a my ji doplníme i o aplikaci klasické Porterovy analýzy pěti sil, která je klíčovým nástrojem pro mikro prostředí školy. Samožrejmě vnímáme, že je rozdíl mezi potřebami malotřídky v regionu bez konkurence v obci a v jejím okolí, a na druhé straně střední školy ve větším městě, kde je působení trhu či kvazi-trhu ${ }^{47} v$ oblasti vzdělávacích služeb pro jejich cílovou skupinu i značné.

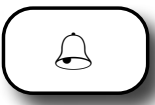

\section{Již samotný proces vytváření marketingového auditu může přinést žádoucí motivování pracovníků ke změně školy, ale také může přinést různé konflikty názorů ve sboru.}

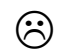

Existuje zde také nebezpeči, že přes dobře zpracovaný audit a celý strategický plán, vnějši podmínky a například rozhodnutí zřizovatele zhatí celou náročnou práci - i to se bohužel v praxi stává.

Naopak také existují príklady z praxe, kdy realizace auditu nasměrovala úsilí školy, a i zřizovatele a dalších partnerů, $k$ její výrazné změně, $k$ inovaci vzdělávacích programů atd. a škola se stala organizací s novou tváří, a postupně i s novou image.

\footnotetext{
${ }^{45}$ Vytvořeni malého marketingového týmu, který bude audit zpracovávat, a potom koordinovat i inovaci celé strategie školy doporučuji i relevantní zahraniční zdroje, př. Everard, Morris, \& Wilson (2004), Lockhart (2016a). ${ }^{46} \mathrm{Na}$ druhou stranu, poradenská činnost zkušených expertů, viz projekt NiDV nebo činnost CZESHA aj.

${ }^{47}$ Pojem použivaji např. DiMartino a Jessen (2018), v ČR tržní pojetí najdeme zejména u Světlíka (1996, 2009).
} 


\section{$\square$}

Za výchozí použijeme vymezení dle Jakubíkové in Eger a kol. (2002, s. 22):

„„Audit je úplné, systematické a periodické zkoumání a hodnocení prostředí a chování vzdělávací instituce $z$ hlediska naplňování příslušných zákonů, standardů, postupů efektivního využívání zdrojů a žádoucího dosahování jejích cílů, zvolených strategií a aktivit, a způsobu jejich uskutečňování, se záměrem identifikovat problémové okruhy, přiležitosti a hrozby a doporučit plán činností směřujicích ke zdokonalení a zefektivnění procesu realizace zvolené strategie.“

Alternativně dle Kotlet a Keller (2007, s. 111):

Marketingový audit je „ucelené, systematické, nezávislé a periodické přezkoumávání prostředí, cílů, strategií a aktivit společnosti, jehož cílem je identifikace problémových oblastí a příležitostí a doporučení dalšího postupu pro zefektivnění marketingu společnosti.“

Marketingový audit je odpovědí na jednu ze základních otázek marketingového řizení:

\section{Kde jsme nyní?}

Je potřebné rozlišovat dva typy auditu:

- $\quad$ externí audit (je prováděn externími subjekty), ${ }^{48}$

- interní audit (vychází z vnitřního informačního a kontrolního systému a je vypracován v rámci vzdělávací instituce).

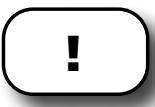

Marketingový audit je podobný situační analýze (Jakubíková in Eger a kol. 2002). Jde však dál. Marketingový audit nehodnotí pouze, zda zvolené poslání a strategie jsou v souladu s prostředím a se zdroji vzdělávací instituce, ale také hodnotí postavení školy na „trhu“ a velikost tohoto trhu, vzdělávací program, rozšiřující aktivity a potřebu jejich inovací, vnitřní strukturu a podmínky ve škole, způsob komunikace, kvalitu informačního systému atd.

\footnotetext{
${ }^{48} \mathrm{~V}$ kontextu našeho školstvi tuto úlohu periodicky plni Čšl a jeji závěry jsou pro jednotlivé školy publikované na https://www.csicr.cz/cz/Dokumenty/Inspekcni-zpravy
} 
Marketingový audit by měl obsahovat i hodnocení kultury vzdělávací instituce, nebot je to právě kultura, která určuje, zda stanovené cíle a zvolené strategie budou úspěšně naplněny nebo odmítnuty (viz kapitola č. 5 ke kultuře školy v předložené publikaci).

\subsection{Nástroje analýzy prostředí školy}

Jak jsme uvedli v úvodu, využijeme zde základní nástroje z marketingu s aplikací pro školy. ${ }^{49}$ Představíme je stručně a případné zájemce odkazujeme na dostupné marketingové učebnice nebo relevantní zdroje na internetu.

Při marketingové situační analýze musíme nejprve sesbírat informace, potom je zpracovat a zanalyzovat, abychom je mohli dále interpretovat. (viz Jakubíková, 2008; Kotler \& Keller, 2007). V situační analýze se snažíme podchytit všechny rozhodující vlivy, které utvářejí podmínky pro fungování naši školy.

\section{!}

Nejznámějším nástrojem je SWOT analýza.

Analýza silných a slabých stránek, přiležitostí a hrozeb. SWOT analýza, se již běžně využivá při plánování i ve školství a v podstatě téměř všichni učitelé se s ní seznámili i při prípravě ŠVP.

SWOT analýza se skládá ze dvou analýz, a to hodnocení vnitřních a vnějších podmínek. Analýza SW představuje hodnocení silných a slabých stránek organizace a analýza OT hodnocení přiležitostí a ohrožení, které se nacházejí ve vnějším prostředí organizace.

SWOT = začáteční písmena anglických termínů:

STRENGHTS

WEAKNESSES

OPORTUNITIES

THREATS silné stránky

slabé stránky

príležitosti

hrozby

Doporučuje se začít analýzou přiležitostí a hrozeb, které přicházejí z vnějšího prostředí školy (viz dále i PEST analýza) a využít i analýzu mikroprostředí (viz

\footnotetext{
${ }^{49}$ Přehled specifických metod a nástrojů pro marketingovou situačni analýzu viz např. Jakubíková (2008, s. 102).
} 
dále Porterova analýza pěti sil). Po důkladně provedené OT analýze realizujeme SW analýzu vnitřního prostředí a v té se podle Jakubíkové (2008) zaměřujeme zejména na cíle, systémy, procedury, zdroje školy, materiální prostředí, kulturu školy, mezilidské vztahy (zejména klima školy), organizační strukturu a kvalitu managementu.

Proto, je vhodné před vypracováním SWOT analýzy školy realizovat nejdřive analýzu vnějšího prostředí (PEST a jeji varianty) a v návaznosti i potom mikroprostředí.

Stručný souhrn ukazuje následující tabulka:

Tabulka 3: SWOT analýza

\begin{tabular}{|c|c|}
\hline Silné stránky & Slabé stránky \\
\hline $\begin{array}{l}\text { Zde se zaznamenávají skutečnosti, } \\
\text { které přinášeji výhody jak } \\
\text { zákazníkům vně školy, tak i uvnitř } \\
\text { školy a škole jako takové. }\end{array}$ & $\begin{array}{l}\text { Zde se zaznamenávají ty skutečnosti, } \\
\text { které dokladuji, že škola nedělá něco } \\
\text { dobře, nebo ty, ve kterých si ostatni } \\
\text { školy vedou lépe. }\end{array}$ \\
\hline Příležitosti & Hrozby \\
\hline $\begin{array}{l}\text { Zde se zaznamenávají ty } \\
\text { skutečnosti, které mohou zvýšit } \\
\text { poptávku nebo mohou lépe uspokojit } \\
\text { zákazníky školy a přinést škole } \\
\text { úspěch. }\end{array}$ & $\begin{array}{l}\text { Zde se zaznamenávají ty skutečnosti, } \\
\text { trendy, události, které mohou } \\
\text { snižit poptávku nebo zapř́činit } \\
\text { nespokojenost zákazníků (studentů, } \\
\text { rodičů, zaměstnanců, zřizovatele atd.). }\end{array}$ \\
\hline
\end{tabular}

SWOT analýza každé školy se liší. To, že se liší silné a slabé stránky škol je přirozené. Školy jsou různě velké, různě dislokované, maji různé učitele a další pracovníky, liší se i žáci atd. Ačkoliv vnějši prostředí, které školy obklopuje, se pro ně výrazně neliší, přesto poskytuje školám různé přiležitosti, ale i hrozby. Co je pro jednu školu přiležitost, může být hrozbou pro školu druhou. Je nutné, aby školy využily svých silných stránek a přiležitostí a vytvořily si jedinečnou konkurenční výhodu, a na druhou stranu, aby eliminovaly hrozby a minimalizovaly své slabé stránky.

POZOR! Co je silnou stránkou, může být zároveň i slabou stránkou a co je přiležitostí, může být i hrozbou. Uvedeme jen obecný příklad. Velké volné prostory... jsou príležitostí pro vytvoření speciální učebny pro..., ale musíte je také uklizet, vytápět atd. Přiležitost v zaměření školy na požadovanou rozšířenou výuku v IT, může být i hrozbou, pokud to škola z hlediska zdrojů nezvládne (finančních, lidských, časových). 
SWOT analýzu zpracováváme přehledně v kvadrantech nejlépe na $1 \mathrm{~s}$. A4. Ke zdůvodnění jednotlivých položek použiváme prílohy apod. SWOT analýza roztažená na více stránek neumožňuje rychlý přehled nejdůležitějších údajů a tím se ztrácí jeden ze základních prezentačních efektů tohoto nástroje.

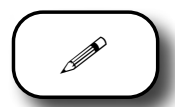

Variantu SWOT analýzy pro marketing škol navrhuje Lockhart (2016a, s. 19). Zdůrazňuje, že pro aplikace tohoto nástroje je v marketingovém plánování kličová pro sebehodnocení. Analýzu by měl vypracovat marketingový tým školy a doporučuje všechny čtyři součásti SWOT vypracovat pro základních $5 \mathrm{P}$, viz tabulka 4.

Tabulka 4: SWOT analýza podle marketingového mixu

\begin{tabular}{|l|l|l|l|l|}
\hline & Silné stránky & Slabé stránky & Přiležitost & Hrozby \\
\hline Produkt & & & & \\
\hline Lidé & & & & \\
\hline Cena & & & & \\
\hline Distribuce & & & & \\
\hline $\begin{array}{l}\text { Marketingová } \\
\text { komunikace }\end{array}$ & & & & \\
\hline
\end{tabular}

Doporučuje nejdřive pro každé „P“ vypracovat týmem vlastní SWOT analýzu a potom zpracovat ten nejdůležitějši souhrn pro celou školu. Po prvním workshopu doporučuje diskutovat výstup s ostatními zainteresovanými a získat i externí pohled, který, jak uvádí, může být inspirujíci i s překvapením. Případné odlišnosti interního a externího pohledu je vhodné řešit objasněním v následné komunikaci. ${ }^{50}$ Teprve potom doporučuje na následném workshopu vypracovat finální verzi. Samož̌ejmě je vhodné každý rok tuto analýzu doplnit či prehodnotit.

\footnotetext{
${ }^{50}$ Lockahrt (2016a) uvádi, že největši problém v praxi bývá hledání příležitostí. Ohroženi doporučuje dále oceňovat tak, jak se to dělá v managementu rizik.
} 


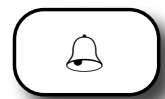

Jinou variantou, hojně používanou v podnikatelském prostředí, jsou tzv. EFE a IFE matice (External a Internal Factor Evaluation), které rozšiřuji SWOT analýzu.

EFE matice je zaměřena na externí pozici organizace nebo jejího strategického záměru (faktory 0 a T). IFE matice je zaměřena na interní faktory organizace nebo jejího strategického záměru (faktory $S$ a W). Po zpracování tabulky faktorů se dále pracuje $s$ jejich váhou a přiděluji se jim body. Matice slouží k vyhodnocování strategie organizace nebo k porovnávání jejich variant. Pro dalši informace doporučujeme zdroje z www nebo marketingových učebnic.

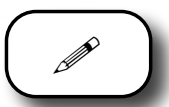

\section{Uvedeme stručný příklad IFE matice.}

Postup provedení:

1. Zpracujeme tabulku hodnocení nejdůležitějších interních faktorů z SW analýzy.

2. Prířadíme každému zjištěnému faktoru váhy v rozsahu $0,00-1,00$ podle důležitosti dané silné nebo slabé stránky školy, kdy suma vah se musí rovnat 1,00 .

3. Jednotlivé faktory ohodnotíme následovně:

- 4 body = výrazná S (silná stránka)

- 3 body = nevýrazná $S$

- 2 body = nevýrazná $W$ (slabá stránka)

- 1 bod = výrazná W

4. Potom vynásobíme váhu a hodnocení u každého faktoru = výsledkem je vážený poměr pro faktor, tedy slabou nebo silnou stránku školy.

5. Sečteme vážené poměry jednotlivých faktorů a výsledkem je celkový vážený poměr.

6. Celkové hodnoceni IFE matice nám zobrazuje výsledný vážený poměr, který hodnotí interní pozici organizace nebo jejího strategického záměru. Nejlepši možné hodnocení je 4 , nejhorší může být 1 . Střední hodnoty se pohybuji kolem hodnoty 2,5 . 
Tabulka 5: Př́iklad IFE matice ZŠ

\begin{tabular}{|c|l|c|c|c|}
\hline S/W & Popis & Váha & Body & Celkem \\
\hline S1 & Kvalitní inovovaný ŠVP & 0,15 & 4 & 0,60 \\
\hline S2 & Zkušený sbor učitelů s praxí & 0,12 & 4 & 0,48 \\
\hline S3 & Výborné IT vybaveni (učebny, i pro učitele) & 0,10 & 3 & 0,30 \\
\hline S4 & Nabízené portfolio kroužků i v kooperaci s DDM & 0,08 & 3 & 0,24 \\
\hline S5 & Dobrá školní jídelna & 0,05 & 3 & 0,15 \\
\hline W1 & Problém s ICT koordinátorem a aprobací pro IT & 0,15 & 1 & 0,15 \\
\hline W2 & Nedostatečný motivační systém školy & 0,13 & 1 & 0,13 \\
\hline W3 & Starši web školy, nepouživáni sociální sítě & 0,10 & 2 & 0,20 \\
\hline W4 & Absence nejmladších učitelů ve sboru & 0,07 & 1 & 0,07 \\
\hline W5 & Zastaralé sportoviště (stadión) školy & 0,05 & 2 & 0,10 \\
\hline & \multicolumn{3}{|r}{} & 2,42 \\
\hline
\end{tabular}

Opět dodáváme, že významná je interní diskuse nad hodnocením důležitosti faktorů a potom v návaznosti samožrejmě nad tím, jak využívat našich silných stránek a jak naopak eliminovat ty slabé. Podobně je vhodné získat k výstupu i externí pohled nejlépe někoho, kdo splní roli „kritického přitele“.

Můžete si v návaznosti zpracovat i varianty IFE matice a potom i v kontextu EFE matice hledat vhodné strategie, o kterých potom samožrejmě vrcholně rozhodne vedení školy.

Stejným postupem vypracujete i EFE matici, kde hodnotíte OT faktory.

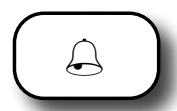

V projektu NiDV při strategickém plánování byla dokonce použita konfrontační matice. Odkaz na ni najdete v literatuře. Považujeme ji za pokročilý nástroj, ale také za ukázku toho, jak se i v oblasti marketingu a managementu regionálních škol aplikují stále více i sofistikovanější postupy z marketingu (NiDV, 2016-2021). 


\section{PEST analýza}

Situační analýzu provádíme proto, abychom nalezli správný poměr mezi příležitostmi $z$ vnějšího prostředí a mezi možnostmi zevnitř organizace. Kromě SWOT analýzy se již ve školství běžně použivá i analýza vnějšího prostředí. Proto ji uvedeme jen stručně.

\section{!}

Vliv vnějšího prostředí (makroprostředí) se označuje zkratkou PEST nebo také PESTLE. Jeho základní složky = faktory jsou uvedené níže. Jedná se 0 vlivy faktorů:

- politicko-právní,

- ekonomické,

- Sociálně kulturní (pro školství též s důrazem na demografické),

- technologické a

- často se popisuji i prírodní a ekologické.

Tato analytická technika slouží k popisu vnějšího okolí organizace. Podstatou PEST analýzy je identifikovat pro každý faktor nejvýznamnější jevy, události a i rizika a popsat vlivy, které působí na organizaci nebo ji budou ovlivňovat. Výstup PEST analýzy bývá také vstupem do SWOT analýzy pro část, která se vztahuje $k$ vnějšímu prostředí.

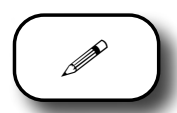

V publikaci Kotler a Keller (2007, s. 115) u kapitoly analýza makroprostředí najdeme následující podkapitoly:

- Potřeby a trendy

- Identifikace hlavních sil

- Populační růst

- Věková struktura populace

- Etnické a další trhy

- Skupiny podle vzdělání

- Chování domácností

- Geografické posuny populace

- Ekonomické prostředí

- Společensko-kulturní prostředí

- Prírodní prostředí 
- Technologické prostředí

- Politicko-právní prostředí

Některé podpoložky z oblasti demografie mohou být inspirativní i pro strategické plánování škol. Vrátíme se k tomu při plánování komunikační kampaně, zejména v práci s cílovou skupinou (viz kapitola č. 8).

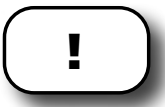

\section{Analýza pěti sil (Porterův model)}

V našich dřivějších publikacích k marketingu školy jsme dále uvedenou Porterovu analýzu pěti sil nepublikovali, a to i z důvodů opakovaných diskusí o trhu a školství atd. Nicméně, v praxi se stále více setkáváme s tím, že i ředitelé MŠ a ZŠ i v malých obcích a relativně bez nejbližši konkurence myslí tržně. Zvažují, jak se rodiče rozhoduji při umístování dětí do MŠ i ZŠ, jak by mohli diferencovat svoji nabídku, přizpůsobit ji potřebám a přáním cílových skupin, jak to celé komunikovat atd. Proto do publikace zařazujeme stručný popis Porterova modelu, který určuje konkurenční tlaky a mapuje rivalitu na trhu. Aplikovaně je použitelný tedy i pro zpracovávání situační analýzy MŠ a ZŠ v zaměření na mikroprostředí. U středních škol je potom hodnocení konkurence běžně použivané již řadu let. ${ }^{51}$

Rivalita trhu závisí na působení a interakci základních sil (konkurence, dodavatelé, zákazníci a substituty). Podstatou Porterova modelu je předvídání vývoje konkurenční situace v odvětví na základě odhadu chování posuzovaných subjektů působících na daném trhu a zařazených do „základních sil“, jež jsou níže specifikovány. Významné pro nás je chování škol a dalších subjektů, které ovlivňuji vzdělávaci prostředí napríklad v našem regionu, ale i chováni zákazníků škol. Podívejme se nejdřive na schéma pěti sil v obrázku 9 na následující straně.

Základní síly z obrázku si v aplikaci pro školy popišeme následovně:

\section{1. riziko vstupu potenciálních konkurentů}

Jak snadné nebo obtižné je pro nového konkurenta vstoupit na trh? Jaké existuji bariéry vstupu? Samožrejmě v oblasti regionálního školstvi to není tak jednoduché, ale děje se to.

\section{2. rivalita mezi stávajícími konkurenty}

Je mezi stávajícími konkurenty silný konkurenční boj? Přestože v oblasti MŠ, ZŠ a SŠ se v praxi spíše jedná o kvazi-trh, konkurence v některých regionech a ve větších městech může být i poměrně velká.

\footnotetext{
${ }^{51}$ Tržni pojetí vždy akcentoval Světlík (1996, 2009), ale v marketingu škol, se mu nevyhýbala ani Jakubíková (2001).
} 


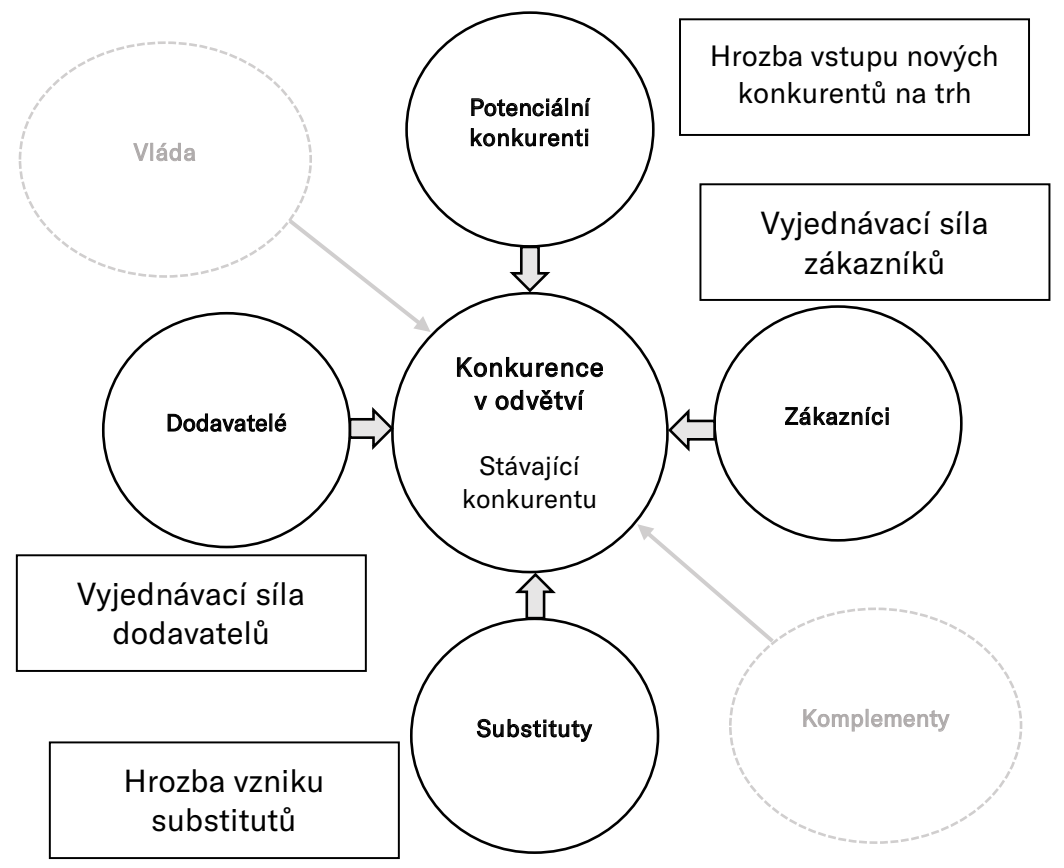

Obrázek 9: Porterův model pěti sil

\section{3. síla zákazníků (odběratelů)}

Jak silná je pozice zákazníků školy? Jak hodně napřiklad mohou spolupracovat a uplatňovat svůj vliv na školu? ${ }^{52}$

\section{4. síla dodavatelů}

Jak silná je pozice dodavatelů? Opět je to pro školství trochu specifické, ale každá škola má řadu dodavatelů, kteři také přímo či nepřímo ovlivňuji její fungování a samožrejmě i konkurenci v odvětví.

\section{5. hrozba substitučních vzdělávacích nabídek}

Jak snadno může být náš vzdělávaci program nahrazen jiným? To je významné zejména v prostředi SŠ. Na jedné straně jsou zde zkušenosti z optimalizace jejich sítě v minulých letech, na straně druhé je zde tlak na inovace $v$ ŠVP a inovace vzdělávací nabídky.

Někdy je použíána i šestá síla, za kterou je považována vláda, a ta je velmi významná právě v oblasti školství (dokonce pod ní můžeme na regionální úrovni zahrnout i kraje a jejich regulace sítě škol apod., připadně obce jako

\footnotetext{
${ }^{52}$ Samozřejmě musíme mít ujasněno, kdo jsou naši zákazníci.
} 
zřizovatele napřiklad několika škol). Výsledkem jejich společného působení není ani tak ziskový nebo ztrátový potenciál odvětví, jak je tomu v podnikání, ale dopad jejich působení na mikro okolí školy je jednoznačně významný.

Poslední, vložený, kruh s pojmem komplementy, může být významný u dalších vzdělávacích či doplňkových vzdělávacích služeb a bude zajímat všechny vzdělávací subjekty, které se také zabývají aktivitami dětí ve volném čase nebo nabídkami v rámci celoživotního vzdělávání. ${ }^{53}$

Porterův model je považován za jeden z velmi silných nástrojů pro stanovování obchodní strategie s ohledem na okolní prostředi organizace a takto jej aplikovaně Ize použit i pro oblast školství.

\section{(2)}

V praxi jsme se již několikrát setkali s podceňováním situační analýzy při strategickém plánování rozvoje školy. V několika připadech to dokonce mělo i významný dopad na dalši životaschopnost školy samotné.

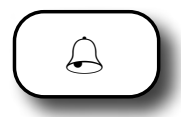

Světlík (2006, s. 32) k tomu uvádí: „Známé rčení, že „nevidí pro stromy les“, platí dvojnásob v případě některých vedoucích pracovníků škol. Školy často reaguji a přizpůsobuji se krátkodobým potřebám nebo změnám místního charakteru a nevnímají širši rozměr propojení svých aktivit a prostředí, ve kterém fungují. Žádná škola nežije v izolaci na pustém ostrově...“

Uvedenou podkapitolu můžeme uzavřít tím, že jen málo škol má ve svém regionu monopolní postavení, které jim ale i v tomto případě $v$ dnešní době stejně nedává možnost nebýt aktivní v důsledku požadavků společenských (reprezentovaných vládou, krajem, zřizovatelem a kontrolovaných Čšı) i měnících se požadavků hlavních cílových skupin. Školy si konkurují zejména ve snaze získat (Světlík, 2009):

- požadované množství kvalitních studentů (žáků),

- dobré pedagogy,

- potřebné finanční prostředky,

- co nejlepší image.

\footnotetext{
${ }^{53}$ Nejenom MŠ, ZŠ, SŠ, ale i DDM, ZUŠ a další subjekty v regionu.
} 


\section{? Co z uvedeného se týká vaší školy?}

\section{Vnitřní prostředí školy}

Analýza vnitřního prostředí školy je pro vzdělávací instituce klíčová a je nutné ji věnovat náležitou pozornost. Nicméně je také zřejmé, že tato oblast bude spojena i s pedagogicko - psychologickou diagnostikou a zcela logicky je předmětem významného zájmu i ČŠl.

Protože předložená publikace je zaměřená na marketing školy, uvedeme zde jen několik základních poznámek, ale odkážeme na důležitou analýzu kultury školy a v tom i klima školy, jež do této analýzy patří, a které se budeme věnovat $v$ dalši kapitole publikace.

Z pedagogického hlediska řadu námětů a nástrojů přináší napřiklad Chvál (2018) v kapitolách: Ptáme se žáků, Ptáme se rodičů, Ptáme se učitelů. Najdeme i publikace prímo zaměřené na klima školy apod. (viz např. Grecmanová, 2008; Petlák, 2006).

\section{!}

„Charakter vnitřního prostředí školy je jednou z hlavních determinant dalšího rozvoje školy. Školy se vzájemně liší ve stylu řizení, tradici, zdrojích, cílech, studijních programech, klimatu." (Světlík, 2009, s. 120)

Autor také upozorňuje na to, že například školy v určitém regionu mají stejné podmínky z hlediska makro prostředí i mikro prostředí, ale právě odlišnosti $v$ jejich vnitřním prostředí vedou $k$ tomu, že „některá škola je úspěšná a jiná je před zavřením“. Vnitřní prostředí pritom patři do oblasti, která může být vedením organizace prímo řízena a ovlivňována.

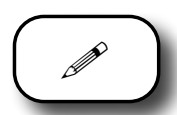

K hodnocení vnitřního prostředí Ize použít metodu VRIO, která je zaměřena na zdroje organizace, jež člení na:

- fyzické (budovy školy a další zařizení jako sportovní hřiště, u SŠ dílny apod., vybavení tříd a další technologické zázemí...),

- lidské (počet a struktura pedagogického sboru a ostatních pracovníků, ale i žáků či studentů, klima školy), 
- finanční (rozpočet školy a případně další disponibilní prostředky),

- nehmotné (historie a tradice školy, know-how, image školy).

Účinnost těchto zdrojů se posuzuje podle těchto kritérii (podle Jakubíková, 2008):

- hodnota zdroje (value), Je nákladný, je snadné jej získat, pronajmout...?

- $\quad$ vzácnost (rareness), Jak je zdroj vzácný, připadně omezený...?

- $\quad$ napodobitelnost (imitability), Jak složité je zdroj napodobit?

- schopnost školy těchto zdrojů využít (organization), Podporuje stávajicí stav organizace efektivní využití zdroje?

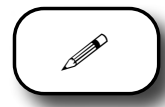

Světlík (2009, s. 122-123) doporučuje vytvořit si tabulku se seznamem zdrojů dle např́klad výše uvedených kategorií a potom jednotlivé podkategorie hodnotit z hlediska silné či slabé stránky například v dílčí stupnici 1-3 a tím si vytvořit i přehled, který by měl korespondovat s příslušnou částí SWOT analýzy (respektive mělo by to být podkladem pro SWOT analýzu).

Tabulka 6: Příklad možného hodnocení zdrojů

\begin{tabular}{|l|c|c|c|c|c|c|}
\hline Zdroj (popis) & \multicolumn{3}{|c|}{ Silná stránka } & \multicolumn{3}{c|}{ Slabá stránka } \\
\hline xy & 3 & 2 & 1 & -1 & -2 & -3 \\
\hline
\end{tabular}

Analýza vnitřních zdrojů a schopností vede $\mathrm{k}$ identifikaci potenciálu školy ke zlepšení se $v$ určité oblasti. $V$ tom analýza zdrojů mapuje jednotlivé zdroje v organizaci a navazujíci analýza schopností je zaměřena na jejich využivání organizací. Tato analýza potom slouži jako podklad pro strategické řizení rozvoje školy v dané oblasti. Výhodou analýzy s využitím metody VRIO je její přehlednost a snadnost použití. Samozřejmě pro finanční oblast nebo i hodnocení tolik důležitých lidských zdrojů v organizaci je možné použít další specifické ukazatele. ${ }^{54}$

Všichni autoři zabývající se marketingem školy se shodnou v tom, že pokud chce vedení školy získat reálný obraz o tom, jaké je klima ve škole a jak rozhodující aktéri vnímají kvalitu školy (zde kvalita jako zákaznická zkušenost), musí se těch rozhodujících skupin ptát, tj. realizovat si vlastní šetření. Porovnáváním

\footnotetext{
${ }^{54}$ Navazujici může být napřiklad portfoliová analýza, která může být zajímavá zejména pro středni školy, jež nabizeji více vzdělávacích programů. Doporučujeme využít matici BCG, podobně Světlík (2009, s. 127-130).
} 
výstupů, analýzou shod ale i rozdílů pohledů, můžeme získat cenné náměty pro strategické řízení a plánování následných aktivit (srovnej s DiMartino \& Jessen, 2018; Eger a kol. 2002; Lockhart, 2016a; Světlík, 2009). ${ }^{55}$

\subsection{Možná struktura marketingového auditu školy}

Problematika marketingového auditu s aplikováním řady dalších možných metod a nástrojů by jistě vydala na samostatnou knihu. Nicméně je nutné tuto kapitolu uzavrít. Než tak ale učiníme, vložíme ještě stručnou poznámku $\mathrm{k}$ auditu marketingového informačního systému školy, protože bez něj není možné uvedené téma uzavřít.

\section{! Audit informačního systému školy}

Marketingový informační systém (MIS) podle Kotlera a Kellera (2007), „to jsou lidé, vybavení a postupy pro sběr, tříděni, analýzu, hodnocení a distribuci potřebných, včasných a presných informací pro marketingové a ostatní manažery."

Pro oblast školství Světlík (2009, s. 97) definoval MIS jako „snahu vedení školy o systematizaci toků informací nezbytných pro rízení školy za účelem jejich rychlé a efektivní využitelnosti.“"

Na levé straně obrázku 10 je prostředí školy, od vnějšího prostředí, přes součásti mikro- prostředí se zdůrazněním nejdůležitějších cílových skupin, kterým je potřebné věnovat zvýšenou pozornost, viz dále i plánování marketingové komunikace atd. Získáním a analýzou primárních i sekundárních informací (barevný střed) získává vedení školy nezbytné podklady pro realizaci základních manažerských funkci. ${ }^{56}$

Informace, které vedení školy potřebuje, pocházejí z jak interních, tak z externích zdrojů a z marketingového výzkumu. ${ }^{57}$ Základní informace, které jsou obligatorní, jsou vymezené Školským zákonem a navazujícím směrnicemi či vyhláškami MŠMT. Každá škola potom vede celou řadu další dokumentace, kde kromě evidence žáků a průběhu vzdělávaci činnosti má i personální evidenci, hospodářskou a účetní evidenci atd. Zde všude jsou data, která by

\footnotetext{
${ }^{55}$ Velmi zajímavý výzkum, který souvisí s tématem, z prostřední našich škol prezentovali Pol a kol. (2013) v publikaci Když se školy učí.

${ }^{56}$ Světlík (2009) upozorňuje, že je samožrejmě velký rozdil mezi tím, jaké a kolik informací potřebuje malá škola $\checkmark$ regionu a velká univerzita.

${ }^{57} U$ regionálních škol se opět spiše jedná o realizaci vlastnich dílčich průzkumů nebo využiván sekundárních dat, které publikuji například Čsú, MŠMT, ČŠI aj. Využijte i časopisů Pedagogická orientace a Pedagogika.
} 


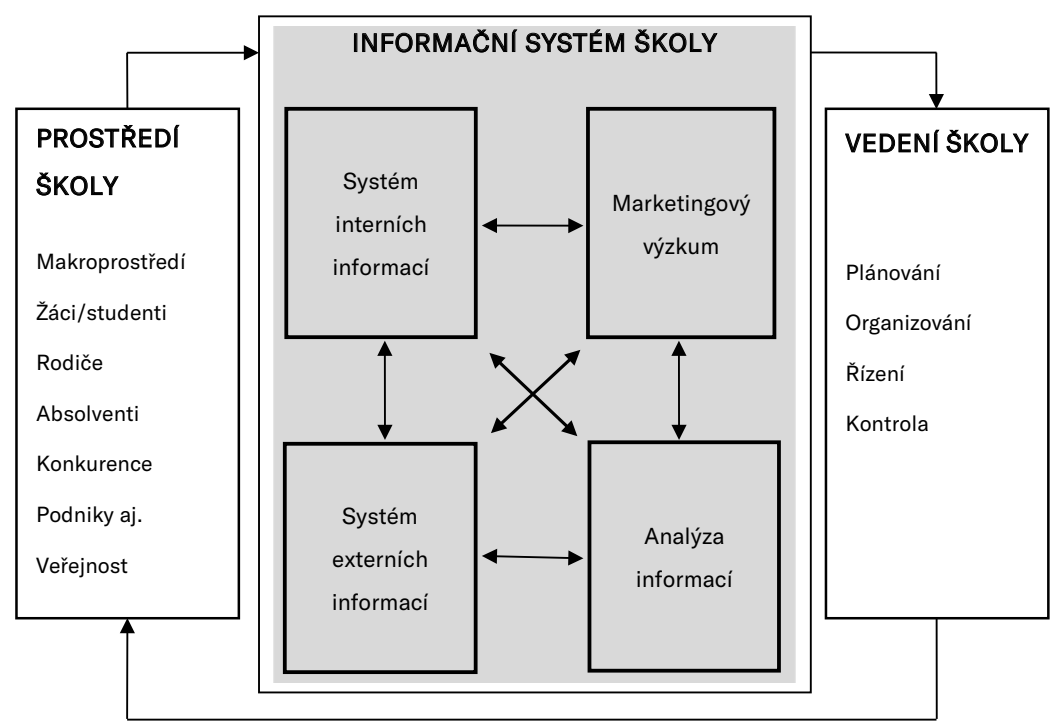

Obrázek 10: Informačni systém školy, dle Světlík (2009, s. 98)

měla být systematicky zpracovávána tak, aby informace byly pro vedení školy co nejpoužitelnější.

Mezi základní prvky informačního systému ve vztahu k žákům patři třídní schůzky, nástěnky, někdy i činnost žákovského parlamentu, ve vztahu k učitelům jsou to porady a informace $v$ interním informačním systému školy, ve vztahu k rodičům informační systémy pro rodiče, www stránky školy s řadou dokumentů a třídní schůzky, ve vztahu k ostatni veřejnosti www stránky školy a výroční zprávy školy. ${ }^{58}$

\section{$?$ Kontrolní otázky a úkoly:}

- Co za posledních 25 let z pohledu makroprostředí (PEST analýza) významně ovlivnilo vaši školu?

- Dokážete na základě Porterova modelu pěti sil popsat postavení vaší školy v mikroprostředi?

- Převed'te SWOT analýzu vaši školy v marketingovém týmu do EFE a IFE matice a diskutujte faktory a jejich hodnocení.

\footnotetext{
${ }^{58}$ Uvádíme zde jen skutečně základni výčet.
} 
- Kdo z externího prostředí nám poskytl zpětnou vazbu k SWOT analýze naší školy?

- Diskutujte model informačního systému školy. Máme vše potřebné?

[DD Literatura:

Jakubíková, D. (2008). Strategický marketing. Praha: Grada.

Kotler, P., \& Keller, K. L. (2013). Marketing management. Praha: Grada.

Světlík, J. (2009). Marketingové řízení školy. Praha: Wolters Kluwer.

Jako alternativní je možné doporučit dokumenty a materiály z projektu NiDV (2016-2021) Strategické řízení a plánování ve školách a v územích. Dostupné z: https://projekty.nidv.cz/strategicke-rizeni 


\section{KULTURA ŠKOLY}

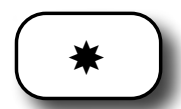

\section{Cíle:}

- Uvědomit si úlohu kultury organizace při realizaci strategie organizace.

- Seznámit se s klasickým modelem kultury organizace, „7S“ McKinsey.

- Umět popsat kulturu školy a připravit její autoevaluaci.

- Uvědomit si znaky silné a slabé, zdravé a nemocné (toxické) kultury školy.

- Ziskat základní poznatky ke změně kultury školy.

kultura školy, model kultury školy, autoevaluace, změna kultury školy

8

Čas potřebný ke studiu základního textu kapitoly je

cca 15 minut + možnost rozšíření o studium externích zdrojů $z$ internetu.

\section{Úvod}

Pedagogika se vždy zaměřovala na klima školy. Ve svém hledání, jak zkvalitnit školu se obsah tohoto pojmu od sociálního klimatu (kdy jde především o vztahy ve škole, třídě) posunul do velkých šířek, které v přehledu ukázali např. Grecmanová (2008) či Mareš (1999)..$^{59}$

Teprve na konci 90. let se v ČR začal rozvíjet moderní management a marketing školy, který přišel i s pojmem kultura školy (Světlík, 1996, Eger a kol., 2002). Dnes je evidentní, že kultura školy je pro řizení školy kličovým pojem.

\footnotetext{
${ }^{59}$ ČŠl stále zůstává u sledováni podmínek vzdělávání s mnoha indikátory, které koresponduji s evaluací kultury školy, viz i výroční zprávy ČŠı. Tento odborný termín ale ve svých manuálech nepouživá.
} 
Reforma školství po roce 1989 i pozdější kurikulární reforma (RVP - ŠVP) byly spojené $s$ významnými změnami v kultuře našich škol. Kdo chce odpovědně rídit školu v 21. století, musí dbát o její kulturu a snažit se řídit její změny dle poznatků z marketingu a managementu.

$\checkmark$ zahraničí je kultuře škol věnovaná pozornost již od 80 . let a různé modely ukazuje např. Bush (2003). Na přelomu tisíciletí se již téma objevuje jako jedno ze základních v moderním managementu škol, př. Prosser (1999), Elsner (1999), Dziergowska (2000), Fidler (2002), Obdržálek a kol. (2004).

Dále si stručně vymezíme kulturu organizace a objasníme u nás používaný model kultury školy (Světlík, 2009) a přineseme náměty pro praktickou řídicí činnost (viz i Eger, 2006).

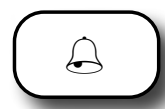

Světově uznávaný guru v oblasti managementu Peter Drucker uvedl:

"Culture eats strategy for breakfast."

Volně přeloženo: kultura si dá strategii ke snídani.

Znamená to, že kultura vaši školy podmiňuje to, jak, a zda vůbec, bude úspěšná vaše strategie. Proto je nezbytně nutné se tématem zabývat a např́íklad v projektu NiDV, zaměřeném na inovace strategií našich škol, bylo všemi experty rozhodnuto, že modul zaměřený na kulturu školy bude první a měl by podnítit tolik potřebnou diskusi o tom „,jak se ve škole věci dělaji“.

\subsection{Koncept kultury organizace}

Koncept kultury organizace si stručně budeme prezentovat na diskutovaném modelu „7S“ firmy McKinsey. Ta jej vytvořila v sedmdesátých letech a model „7S“ je dodnes využíván pro strategické řízení organizací. Původní přístupy managementu zaměřené zejména na tzv. tvrdé prvky řizení byly později tzv. školou lidských vztahů obohacené o měkké prvky řizení a v aplikaci pro řizení organizace bylo obojí vhodně spojeno právě v konceptech kultury organizace. Uvedený konstrukt je jeden z nejznámějších a pro náš účel nám umožňuje $v$ kostce představit to podstatné ve vztahu ke kultuře organizace. Uvádí se také, že je to technika pro management, kterou si můžete strukturovaně zhodnotit kritické faktory libovolné organizace. 


\section{!}

Model je nazýván „7S“ protože názvy sedmi základních prvků začínají v angličtině písmenem $S$ a jsou to: ${ }^{60}$

- $\quad$ Strategie (Strategy)

- Struktura (Structure)

- Systémy (Systems)

- Styl práce vedení (Style)

- Spolupracovníci-personál (Staff)

- Schopnosti (Skills)

- Sdílené hodnoty (Shared values)

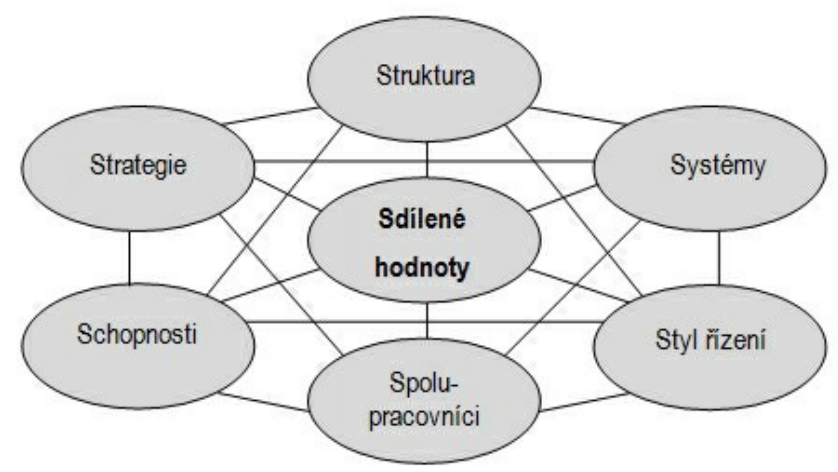

Obrázek 11: Model „7S“ McKinsey

První tři prvky (strategie, struktura, systémy) jsou považovány za základní, tzv. tvrdé prvky řízení - hardware.

Další čtyři prvky (spolupracovníci, styl řízení, schopnosti a sdílené hodnoty) jsou považovány za pomocné prvky úspěchu, tzv. měkké prvky řizení - software.

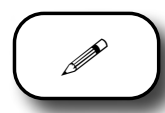

Předložený model má sdílené hodnoty, které představují jádro kultury organizace, uprostřed.

\footnotetext{
${ }^{60}$ Model kultury organizace firmy „7S“ McKinsey dle Payne (1996) a Kotler (2001).
} 
- Struktura = schéma organizační struktury, vztahy nadřizenosti a podřizenosti, způsob rozdělení a integrace úkolů, formální delegování pravomocí a odpovědnosti v organizaci.

- Strategie $=$ zde ji stručně vymezujeme jako definování vize a cílů organizace a cesty jejich dosažení.

- Systémy = procesy a postupy při každodenní práci, včetně psaného kodexu chování. Dnes sem také řadíme systém komunikace, informační i kontrolní systémy $v$ organizaci.

- Schopnosti = dnes se pod tím rozumí znalosti a kompetence, které jsou prostřednictvím zejména lidí v organizaci k dispozici včetně jejich synergického efektu.

- Spolupracovníci (zaměstnanci) = lidé v organizaci, respektive struktura lidí, tým, podpora kvalifikace, vztahy mezi nimi aj.

- $\quad$ Styl = způsob chování managementu (jak přistupuje k řízení), hospodaření s časem, zaměření na lidi a úkoly, společný způsob chování a jednání v organizaci atd.

- Sdílené hodnoty = toto $S$, které je uprostřed, můžeme spojovat s pojmem firemní kultura. Sdílené hodnoty prítom souvisí s vizí a posláním organizace.

\section{!}

Při snaze realizovat efektivní změnu $v$ organizaci musí být brány $v$ úvahu všechny faktory, jinak je pravděpodobné, že například realizace strategie organizace nebude úspěšná. Uvádí se, že pokud se nevěnuje pozornost jakémukoliv $z$ uvedených faktorů, může potom selhat celá struktura.

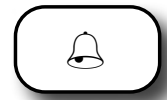

Uvedený koncept ${ }^{61}$ souvisí s tzv. „hledáním dokonalosti“, které svým bestsellerem proslavili Peters a Warterman (2001). Ti také stručně vymezili kulturu organizace následovně: „Kultura se projevuje také tím, že všichni zaměstnanci vědí, co maji ve většině situací dělat. Čím je kultura vyšší, tím méně je potřeba organizačních příruček, organizačních zásad..." To je jistě zajímavý závěr pro každého ředitele školy.

${ }^{61}$ Ve školství to známe z anglického prostředi jako hledání znaků efektivních škol, např. viz Everrad a kol. (2014). 
Je vhodné poznamenat, že již pojem kultura je mezioborovým pojmem a při jeho vymezováni nedospěli autoři ke konsenzu. Je to poměrně složitý abstraktní koncept, který byl ve vztahu k organizaci zaveden na přelomu 80. a 90. let minulého století a v oblasti managementu souvisel s rozvojem řizení lidských zdrojů a v oblasti marketingu s novým pojetím organizace a s poznáním důležitosti vnějších i vnitřních vztahů. Uvedeme proto ještě jedno doplňující vymezení.

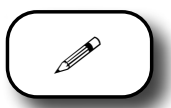

Armstrong (2007) uvádí několik stručných definic, ale v roce 2015 se již přiklání k výstižnému vymezení od Deal a Kennedy (2000), kteří kulturu organizace vymezili jako „způsob, jakým v organizaci něco děláme“. Kultura organizace potom dle Armstronga (2015, s. 164) „zahrnuje hodnoty, normy, přesvědčení, postoje a předpoklady, které nemusí být nijak vyjádřené, ale rozhodně určuji způsob chování lidí i způsob vykonávání práce“.

S odkazem na řadu autorů potom uvádí, že hodnoty a normy jsou základem kultury organizace a utvářejí se čtyřmi způsoby (Armstrong, 2015):

1. Kulturu formuji lídři, zejména ti, kteří ji formovali v minulosti.

2. Kulturu formuji tzv. kritické prípady - důležité události, které slouží jako zdroj ponaučení o žádoucím nebo nežádoucím chování.

3. Kultura vychází z potřeby udržovat efektivní kulturní pracovní vztahy mezi členy organizace, což vytvárí hodnoty a očekávání.

4. Kulturu ovlivňuje prostředí organizace, které může být dynamické nebo neměnné.

Armstrong $(2007,2015)$ často odkazuje na pojetí kultury od Schein (1984) a viz i Lukášová, Nový a kol. (2004). Ten svůj model organizační kultury (velmi citovaný a diskutovaný) staví na třech rovinách organizační kultury, na nichž je kultura manifestována (porovnej dále s přistupem Kulhavy, 1993) a jeji projevy jsou tudíž pozorovatelné. Můžeme je stručně popsat následovně:

1. Artefakty - jsou nejvíce na povrchu, nejviditelnější a také nejvíce a poměrně snadno ovlivnitelné. Patři sem i vizuální struktura organizace a viditelné projevy procesů.

2. Zastávané hodnoty, pravidla a normy chování, je to rovina částečně vědomá, a tedy zejména pro vnějšího pozorovatele jen částečně zřetelná a celkově hưře ovlivnitelná při realizaci změn kultury. Také sem patři strategie, cíle a vize. 
3. Základní předpoklady jsou dle Schein nejhlubší rovinou, jež zahrnují nevědomé a pro příslušníky dané kultury přitom samozřejmé názory a myšlenky. Zdrojem vzniku základních předpokladů je opakovaná zkušenost, jež vzniká při řešení problémů vztahujících se k adaptaci na vnějši prostředí, problémů souvisejicích s integraci vnitřních procesů za účelem adaptace, ale řadí se sem i hlubší problematika související s chápáním pravdy, času, lidských vztahů atd. (společné vnímání a myšlení)

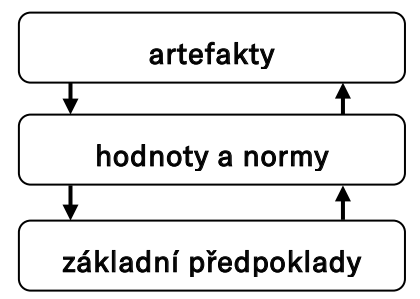

Obrázek 12: Tři úrovně kultury dle Schein (1992),

podle Lukášová, Nový a kol. (2004)

\subsection{Kultura školy a model kultury školy}

V následujícím textu uvedeme definici pojmu a následně základní schéma kultury školy, které doporučujeme využívat při objasňování kultury školy např́iklad i ve vedení školy či sboru školy.

\section{$\square$}

„Kultura školy je složitým souborem norem, postojů, přesvědčení, chování, hodnot, obřadů, tradic a mýtů, které jsou hluboce zakořeněny v samém jádru organizace. Kultura je historicky přenášeným významovým vzorcem, který má neuvěřitelnou moc při formování toho, co si lidé myslí a jak jednají. Každá škola má svou kulturu. Některá je pohostinná, některá je toxická.“ (Barth in Grogan a kol., 2013, s. 198)

\section{!}

Z marketingového hlediska definujeme kulturu školy dle Eger a Jakubíková (2000, s. 7): 


\begin{abstract}
„Kultura škol je vnitřním fenoménem, který je primárně vytvářen a využíván v oblasti řízení a vztahu k vlastním zaměstnancům školy. Jedná se o souhrn představ, přístupů a hodnot ve škole všeobecně sdílených a relativně dlouhodobě udržovaných.“
\end{abstract}

„Projevuje se ve specifických formách komunikace, realizací jednotlivých personálních činností, způsobech rozhodování ředitelů škol a jejich zástupců, v celkovém sociálním klimatu, a především ve společném přibližně shodném náhledu učitelů a dalších zaměstnanců školy na dění uvnitř školy, v jejich obdobné interpretaci a hodnocení, i ve vzhledu budov, učeben, šaten, dvorů, hřišt, školních jídelen atd., což znamená, že se projevuje materiálně i nemateriálně, uvnitř i vně školy." (Jakubíková, 2001) Je nehmatatelná, ale ne nepoznatelná. Vzniká, rozvijí se, případně se mění či zaniká v určitém zcela konkrétním čase a místě (Bedrnová, Nový a kol., 1998). Kultura školy má přímý i neprímý vliv na celkové výsledky školy.

Souhlasíme s Pol a kol. (2005), že kultura školy je celistvým pojmem, který spojuje jednotlivé oblasti fungování školy.

Niže uvedené schéma (obrázek 13) přehledně popisuje prvky kultury školy a může být i dobrým základem pro otevřeni diskuse ve sboru školy „o kultuře naši školy“. Schéma vycházi z práce Světlíka (1996) a dále informace můžete najít v práci Jakubíkové (2001) nebo Egera (2006) či Světlíka (2006).

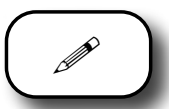

Jak je patrné z niže uvedeného obrázku 13, jádrem, piliřem i duší kultury školy jsou hodnoty. Hodnoty nabízeji směr, kterým by se měli všichni zaměstnanci každý den ubírat, směřuji jejich chování. Podobně významné jsou psané i nepsané normy a samozřejmě i vztahy mezi lidmi v organizaci (viz dále i klima a kultura školy).

Dalšími prvky kultury školy jsou verbální symboly, kam řadíme i tzv. hrdiny školy, příběhy o škole, ale i mýty s ní spojené, jež jsou komunikovány i prostřednictvím tzv. kulturní sítě.

Hrdinové, jsou (magické) osoby, které jsou přikladné zejména pro komunitu školy. Mají osobitý charakter a styl. Dělají věci tak, jak by je chtěli dělat i jiní, kdyby to uměli nebo kdyby se nebáli. Hrdinové jsou správní zaměstnanci školy, ale i př́ikladní žáci či studenti.

Pod symboly chování najdeme i procesy a funkční procedury, jež prímo souvisí s hlavní vzdělávací činností ve škole. 
Symboly jsou pro kulturu školy velmi důležité. Projevuje se v nich komunikace základních hodnot, norem a vztahů, tedy toho, co je pro kulturu organizace kličové.

Kulturní sít je spojena se silnou kulturou. Je neformální, má svá pravidla, která nejsou psaná, jsou ale dodržovaná, a je nutno je respektovat. Tato sít má primární důležitost v komunikačním procesu uvnitř celé školy.

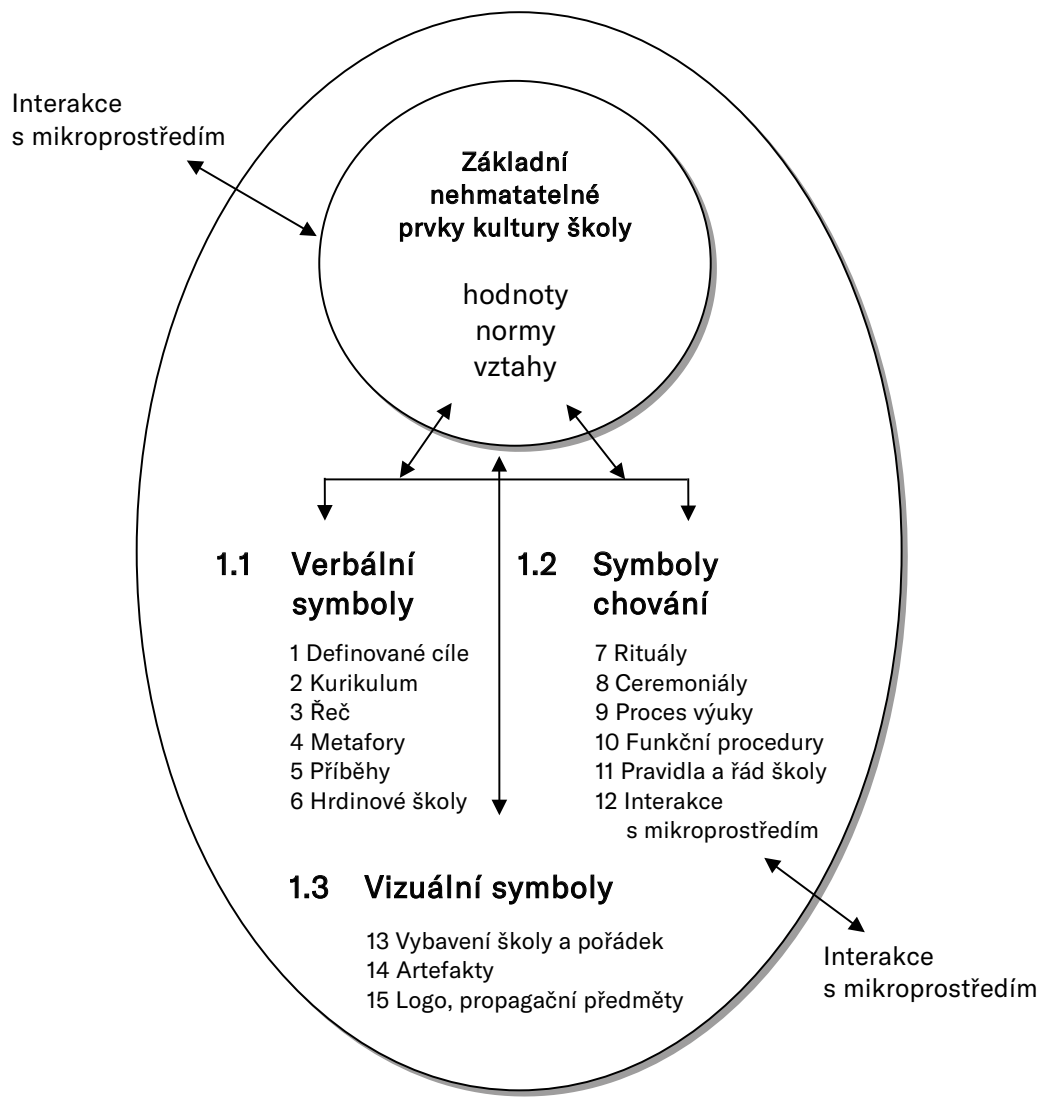

Obrázek 13. Schéma kultury školy, Eger a kol. (2002) podle Světlík (1996)

Z hlediska školského managementu můžeme dle Bush (1995) poznamenat, že kulturní modely se v oblasti řizení vzdělávacích institucí začaly využívat na přelomu 80. a 90. let a Bush za důležitý považuje článek (Harris, 1992), ve kterém autor vyzdvihl zaměření na hodnoty a rituály atd. a hlavně 
zdůraznil to, že leadeři mají centrální = hlavní roli v ovlivňování kultury organizace.

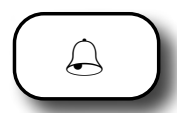

Zvažte: Wagner (2006) na základě řady výzkumů shrnuje, že je prokázané spojení mezi kulturou školy a očekáváním i výsledky ve vzdělávacím procesu. Tento závěr je vhodné diskutovat i s citátem Druckera z úvodu $\mathrm{k}$ této kapitole. ${ }^{62}$

\subsection{Kultura školy a klima školy}

V souvislosti s kulturou organizace je zejména ve školství důležitý i pojem klima školy. Určitý zmatek do problematiky vnáši to, že lidé obvykle používají pojem atmosféra, ale myslí tím to, co odborně vymezujeme jako klima pracoviště - školy. V této souvislosti si můžeme pomoci výkladem uvedených pojmů z hlediska pedagogiky a tím je jednoznačně zařadit a porovnat:

Především atmosféra sem vlastně nepatří, protože je to spiše přechodný stav určitého naladění na pracovišti (ve třídě), který vychází z kultury, je ovlivněn sociálním klimatem a krátkodobě jej spouští určité, ale velmi různorodé podněty.

\section{!}

Klima jsme pro ujasnění návaznosti pojmů upřesňovali na sociální klima, které vyjadřuje kvalitu interpersonálních vztahů na pracovišti a je zřejmé, že je více stálé a že je tak významnou součástí kultury organizace. Pauknerová (2006, s. 199) jej vymezuje jako charakter „převládajících vzájemných vztahů mezi jednotlivými členy pracovní skupiny, jako jakýsi soulad mezi jednotlivými pracovníky“ a uvádí, že sociální klima podmiňuje pracovní jednání pracovníků, průběh i výsledky jejich pracovní činnosti. Schein (1996) považuje klima v organizaci za jednu ze součástí manifestace její kultury.

\footnotetext{
${ }^{62}$ V rámci projektu NiDV jsme vyhodnotili autoevaluační dotazníky kultury školy a výsledky ukazuji na to, že kde je lépe hodnocen management školy, DVPP a inovace vzdělávaciho procesu, jsou také očekávány vyšši výstupy ve vzdělávacím procesu. Podobně to dopadlo i u souboru studentů pedagogických fakult, kteři byli na praxi ve školách (Eger \& Prášilová, 2020) a hodnotili ze svého pohledu kulturu školy, kde vykonávali praxi.
} 
Problematiku ve vztahu ke školství ujasňuji MacNeil a kol. (2009) následovně: kultura organizace by měla být nazíraná z antropologického pohledu, klima organizace z pohledu psychologie. To by odpovídalo i tomu, že zejména klima třídy je obvyklým tématem pedagogické psychologie a pro jeho zjištování existuji i standardizované nástroje.

\section{$\sqrt{ }$}

Definovat klima školy můžeme dle Mareš a kol. (2003-2005) následovně:

„\$Klima školy je relativně stálá kvalita vnitřního prostředí, je to vnímané fyzikální a psychologické prostředí školy včetně vztahů uvnitř skupin a mezi těmito skupinami: vedení škol, učitelé, žáci, rodiče, komunita."

Naopak Grecmanová (2008, s. 33) definuje klima školy poměrně široce jako „projev jejího prostředí zahrnujícího ekologickou, demografickou, sociální i kulturní dimenzi. Klima vnímají, prožívají a hodnotí všichni ti, kterých se týká, tzn. žáci, rodiče ${ }^{63}$ učitelé a veřejnost. Klima školy představuje klima třídy, klima učitelského sboru, komunikační, organizační či školní klima.“

Z hlediska vztahu klima školy a kultury školy se ztotožňujeme s vyjádřením Obdržálka (2002, s. 71) „V klimatu školy se projevuje manifestace kultury školy dovnitř... Školní klima je prožívání kultury školy jejími učiteli a žáky.“ A jen dodáváme, že pro diagnostikování klimatu třidy máme $k$ dispozici standardizované nástroje, viz např. Petlák (2006) či Grecmanová (2008).

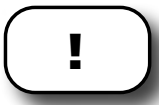

Podkapitolu můžeme uzavřít námětem z práce Guenert (2008). Autor konstatuje, že kultura školy a klima školy nejsou tou samou „věci“, ačkoliv to v praxi řada lidí takto směšuje. Také uvádí, že je daleko jednodušší změnit klima než kulturu školy. Kultura podle něj představuje osobnost organizace a klima očekávání či přistup a uzavírá konstatováním, že ,je jednodušší změnit př́stup než osobnost“". V tabulce uvádí rozdíly.

Uvedeme výbèr:

${ }^{63}$ Odlišné světy učitelů a rodičů našich škol prezentuje napřiklad studie Martanové a Konůpkové (2019). 
Tabulka 7: Klima a kultura školy (dle Guenert, 2008)

\begin{tabular}{|l|l|}
\hline Klima & Kultura organizace \\
\hline Flexibilní, je možné jej jednodušeji měnit & Potřebujeme řadu let pro její rozvoj \\
Založeno na vnímání & Založena na hodnotách a důvěře \\
Je vnímána při vstupu & Nelze ji jednoduše vnímat \\
Je všude kolem nás & Je naši součástí \\
Cesta, jak vnímáme okolí & Cesta, jak realizujeme „věci“ kolem nás \\
\hline
\end{tabular}

„Pochopení rozdílů a shod mezi kulturou a klimatem je pro nás výborným nástrojem pro změnu naši školy.“ (Guenert, 2008, s. 4).

Zvažte:

Pojem kultura školy není ale zcela ustálen v oblasti školského managementu v ČR. Napřiklad ve Výroční zprávě ČŠl za rok 2014/2015 se pojem „kultura školy“ nevyskytuje. Nicméně na s. 41 najdeme: Z hodnocení ČŠı vyplynulo, že $97,2 \%$ reditelů škol (z toho 54,8 \% rozhodně ano) se daři úspěšně vytvářet pozitivní klima školy, jen necelá $3 \%$ ředitelů škol jsou v tomto směru neúspěšná. Ředitelé škol vyjádřili převážně spokojenost s jednotlivými oblastmi školního klimatu... Podle učitelů je nejméně pozitivně hodnocenou oblastí možnost podílet se na rozhodování o škole.

\subsection{Jak je možné popsat kulturu školy?}

Podrobný popis kultury školy není jednoduchou záležitostí. Pro praktický management ve škole využiváme nástroj zaměřený na manifestaci kultury školy, který se již osvědčil a který při určitém kompromisu přináší relevantní poznatky (Eger, 2006). Můžeme také uvést, že se dle pojetí Schein zaměřuje zejména na artefakty kultury organizace. Než si jej dále představíme, uvedeme stručně několik poznámek $\mathrm{k}$ faktorům, které obecně ovlivňuji kulturu našich škol, a tedy i kulturu každé naší školy.

\section{Determinanty kultury školy}

Faktory, které ovlivňují námi řizenou organizaci, je vhodné rozdělit do tří kategorií, a to na faktory, které nemůžeme ovlivnit, ale ovlivňuji přímo či nepř́mo naši organizaci, na faktory, které můžeme ovlivnit jen částečně a na faktory, 
které máme či můžeme mít plně pod kontrolou. V praxi to není vždy tak úplně jednoduché, ale vhodná pomůcka pro strukturaci determinant to určitě je. Vvužijeme zde PEST analýzu i Porterovu analýzu pěti sil, také analýzu vnitřního prostředí. Tento přistup je také relevantní a podrobněji s ním pracujeme při vytváření strategie školy.

Proto nyní jen stručně oslovíme hlavní determinanty, které je nutné brát v úvahu při autoevaluční diskusi nad tématem „kultura naší školy“. Ta, jak víme, není ve vzduchoprázdnu, ale existuje v podmínkách naši společnosti, které se i poměrně dynamicky mění. Navíc, at chceme, či nechceme, žijeme i v otevřeném globalizovaném světě, a i tomuto vlivu se nemohou naše školy vyhnout.

\section{2}

Kulturu školy je nutné také vidět ze širších hledisek. At si to přiznáme, či ne, je kultura každé naši školy ovlivněna EU, historií střední Evropy, historií i kulturou naši společnosti atd. ${ }^{64}$

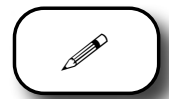

Obecně si můžeme determinanty kultury vymezit podle Pfeifera a Umlaufové (1993) na:

- vnější a vnitřní,

- hmotné a nehmotné,

- minulé a současné,

- ovlivnitelné a neovlivnitelné,

- brzdíci shodu vžité a strategicky potřebné kultury a determinanty podporující shodu.

Mezi vnější determinanty patři: charakter kultur vyšších řádů, geografická dislokace, ekonomický systém, sociální systém, politické preference, legislativa, ekologie, úroveň vědy a výzkumu, digitalizace a rozvoj ICT, tržní pozice školy v regionu.

Mezi vnitřní determinanty patři: historie organizace, její velikost, právní formy, management školy, jeji zaměstnanci, míra setrvačnosti vžité kultury školy. ${ }^{64}$ Dřivějši zkušenosti z Anglie ukazují, že aspirace centrálních orgánů jsou někdy ohrožením pro zaběhlé kultury
dilč́ich škol (Leithwood a kol., 1994). 
Hmotné determinanty zahrnuji: majetek školy, úroveň vybavení, nehmotné pak: zájmy vlastníků (zřizovatele), zájmy managementu, zájmy zaměstnanců, zájmy žáků, rodičů apod.

\section{Manifestace kultury školy}

Nyní představíme nástroj pro popis kultury školy, který vychází z práce Kulhavého (1993) a aplikace, kterou pro školství pripravila Jakubíková (1998). Tento nástroj pro autoevaluační popis kultury školy využiváme v menších úpravách dílčich položek od roku 1999 a můžeme uvést, že se v praxi osvědčil. Jeho konstrukce vychází z následujícího tvrzení:

\section{!}

Kultura se projevuje (manifestuje) materiálně a nemateriálně, a to směrem dovnitř i vně školy. Vytvořené čtyři kvadranty tvoři základ pro její popis.

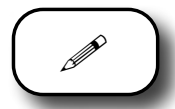

Niže uvedená tabulka je základem pro vytvoření popisu kultury vaší školy. Je vhodné jej tvořit v pracovním týmu školy a dále diskutovat ve sboru školy, popř. s dalšími partnery školy.

Tabulka 8a: Základní přehled manifestace kultury školy

\begin{tabular}{|c|c|c|}
\hline & Materiální manifestace & Nemateriální manifestace \\
\hline 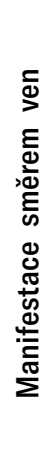 & $\begin{array}{l}\text { budovy, hřiště, školní pozemky } \\
\text { stánky na veletrzích a výstavách atd. } \\
\text { venkovní označení školy, nápisy, znak } \\
\text { školy, vlajka školy } \\
\text { fasády, dveře, okna a jejich výzdoba } \\
\text { domovské barvy } \\
\text { oblečení zaměstnanců někde } \\
\text { i studentů (mnohdy i celkový } \\
\text { vzhled) } \\
\text { tiskoviny, vizitky, propagační } \\
\text { materiály školy } \\
\text { dárkové předměty }\end{array}$ & $\begin{array}{l}\text { vzdělávaci program školy } \\
\text { školné, různé poplatky } \\
\text { chování zaměstnanců i žáků vůči } \\
\text { veřejnosti } \\
\text { orientace v čase (dlouhodobý, } \\
\text { krátkodobý horizont) } \\
\text { formy nabídky výuky } \\
\text { systém marketingové komunikace: } \\
\text { marketingová komunikace, podpora } \\
\text { prodeje, Public Relations a publicita, } \\
\text { přimý prodej, přimý marketing } \\
\text { vztahy žák-učitel-rodič-společnost }\end{array}$ \\
\hline
\end{tabular}


Tabulka 8b: Základní přehled manifestace kultury školy

\begin{tabular}{|c|c|c|}
\hline & Materiální manifestace & Nemateriální manifestace \\
\hline 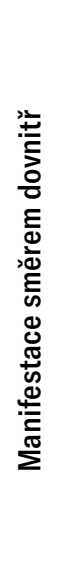 & $\begin{array}{l}\text { vstupy, dvory, předzahrádky i vnitřní } \\
\text { hřiště, využití a úprava pozemků } \\
\text { i jiných prostor } \\
\text { vrátnice - jeji vzhled a uspořádání, } \\
\text { manifestace úspěchů školy - tabule } \\
\text { cti, výsledky soutěži, prezentace } \\
\text { úspěšných absolventů školy atd. } \\
\text { vnitřni prostory budov (chodby, } \\
\text { místnosti, dílny, laboratoře, sociální } \\
\text { /zařízení, zákoutí atd.) } \\
\text { architektura } \\
\text { barvy, osvětlení, větrání, vytápění } \\
\text { vybavení vnitřních prostor (stroje, } \\
\text { přistroje, nábytek aj.) } \\
\text { informačni systémy (orientační tabule, } \\
\text { označeni místností, aj.) }\end{array}$ & $\begin{array}{l}\text { proces a organizace výuky } \\
\text { klima (teplo školy, sociální } \\
\text { temperatura, etika) } \\
\text { vztah nadřízený-podřízený } \\
\text { formální a neformální komunikace } \\
\text { uvnitř školy všemi směry, tj. } \\
\text { nadřizený-podřizený, vyučujíci-žák, } \\
\text { vedení mezi sebou, učitelé mezi } \\
\text { sebou, žáci mezi sebou, ostatní } \\
\text { pracovníci školy atd. } \\
\text { základní hodnoty, vnitřní etika } \\
\text { hodnota času } \\
\text { řeč } \\
\text { hrdinové } \\
\text { přiběhy, historky, ceremoniály } \\
\text { vztah k profesi a k vlastní práci }\end{array}$ \\
\hline
\end{tabular}

Projevy kultury Ize sledovat: $v$ rovině dojmů, které škola vzbuzuje u vlastních pracovníků i v široce pojatém okolí, při komunikaci uvnitř i vně školy, v rozhodovacích procesech školy.

Materiální manifestace kultury školy působí zejména na veřejnost, ale také na žáka a jeho rodiče. Vizuální symboly posiluji proces identifikace se školou u všech, kteři mají ke škole blizko.

S nemateriální manifestací kultury školy se často potenciální žáci a jejich rodiče, potenciální zaměstnanci a veřejnost seznamuji mnohem dřive než s materiálni manifestací a vytvárí si první názor na školu. Ten může velmi silně ovlivnit jejich rozhodování o výběru školy, na které chtějí studovat, nebo být zaměstnáni, být jejími sponzory atd.

\section{?}

Co z uvedeného popisu může působit jako signál kvality (také projev značky) školy?

\section{$?$}

Představte si, že jste návštěvník vaši školy, přicházíte ke škole, vcházíte dovnitř, procházíte školou a vstupujete přes kancelář sekretářky k řediteli 
- ředitelce školy. Cestou potkáváte řadu pracovníků školy a žáky či studenty, protože je přestávka. Jak na vás bude materiálně i nemateriálně působit škola?

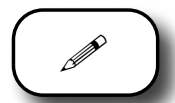

Jednodušší přehled vhodný pro autoevaluační účel můžete získat zadáním dotazníku pro kulturu školy (informace o vytvoření dotazníku jsou in Eger a kol. 2002), přiloha $E^{65}$

Výhodou dotazníku je jeho rychlé vyplnění, možnost zadání pro členy sboru a popř. pro členy vedení zvlášt. Po jeho vyhodnocení je opět možné jej využít pro následnou diskusi ve sboru na téma kultura školy jako součást její autoevaluace.

Pro komplexnější pohled je možné jej kombinovat s výše uvedeným postupem popisu kultury školy dle kvadrantů jeji manifestace nebo se SWOT analýzou školy, auditem či dalšími autoevaluačními materiály, ale i hodnocením Čšl atd.

\subsection{Silná a slabá kultura organizace}

V souvislosti s poznáváním kultury organizace a s vytvářením jejího popisu se diskutují pojmy silná a slabá kultura organizace a také zdravá a nezdravá kultura organizace. (používá se také pozitivní a negativní nebo i toxická) Pojd'me si je nyní stručně objasnit.

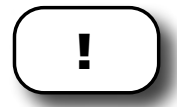

Silná kultura je tvořena systémem neformálních pravidel, která vyjadřují to, jak se lidé většinou chovají. Silná kultura dává lidem lepší pocit o účelnosti toho, co dělají. Usnadňuje jasný pohled na školu, vytváři podmínky pro dobrou komunikaci uvnitř i vně školy, umožňuje rychlé rozhodování, snižuje nároky na kontrolu, zvyšuje motivaci a loajalitu všech pracovníků i žáků, snižuje fluktuaci, zajištuje stabilitu sociálního systému atd. Je především nositelem základních cílů školy a celkové filosofie řizení, činí školu přehlednou a snadno pochopitelnou (Eger, 2006; Jakubíková, 2001). Silná kultura vytváŕí synergický efekt, který se projevuje v koordinaci, integraci a motivaci (Bedrnová, Nový a kol., 1998).

\footnotetext{
${ }^{65}$ Tento dotaznik byl použit již ve stovkách škol v ČR a na Slovensku. 0 jeho verzi v angličtině projevili zájem i experti z Polska, ale i Turecka. Detailni popisy jsou průběžně inovovány a samožrejmě je doporučujeme přizpůsobovat národním prostředím v připadě aplikace v jiných zemích.
} 
Slabá kultura se projevuje v konfliktní zájmové diferenciaci zaměstnanců nebo $v$ jejich fragmentaci do konkurujících si skupin nebo i nízkým zájmem zaměstnanců o organizaci a společnou práci. Bush (1995) používá termín „balkanizovaná kultura“. I tyto konfliktní diferenciace můžeme na našich školách zaznamenat. $V$ těchto prípadech se ukazuje souvislost s efektivitou školy a dopad na ni. Ve slabých kulturách lidé ztráceji čas tím, že se pokoušejí zjistit, co a jak by mělo být uděláno. Jsou zde rozdílné názory (Bush, 1995) na vyučování, vyučovací styly, disciplínu a kurikulum.

Můžeme se také setkat s pojmy zdravá nebo nemocná kultura. Jejich odlišení Ize vysledovat v názorech a postojích na pět základních oblastí (Mikušová, 1999): vztah k okolí, vztah pravdy a skutečnosti, charakter lidské povahy, charakter lidské činnosti, charakter lidských vztahů. Za měřítko „zdravotního stavu“ se považuje jejich připravenost na krizi, to, zda jsou schopny a ochotny se vyrovnat s problémem či přímo s krizí. U zdravé kultury školy (Sato a kol., 2016) se také uvádí její pozitivní vliv na vzdělávací proces a vztahy mezi učiteli a žáky. V návaznosti na to Peterson (Deal \& Peterson, 1999) na základě výzkumu uvádí, že negativní kultura školy vytváří toxické prostředí, kde jsou vztahy mezi učiteli konfliktní a zaměstnanci nevěri ve schopnost studentů uspět a obecně mají negativni očekávání.

\section{(2) Zvažte následující téma (dle Barth in Grogan a kol., 2013):}

Kultura školy může mít svoje nediskutovatelná témata či tabu. Může to být napřílad to, jak je škola řizena či prímo „postava ředitele“. Nebo to, ,jak se zde rozhoduje“. V řadě škol je to problém vyjadřování se k etniku či rase. Velmi ožehavým tématem je například učitel s nedostatečným výkonem. Zdraví školy je také možné posuzovat podle počtu témat, o kterých se nediskutuje. Čím jich je více, tím větši je to problém.

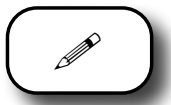

Jak se níže uvedené položky projevuji ve vaší škole?

Jako námět pro praktické použití uvádíme níže prezentovaný výčet možných předností a nedostatků silné kultury organizace. Opět jej můžete použít při diskusi ve sboru školy a uvádět přitom přiklady ze školské praxe.

Sledujte v seznamu, jak silná kultura může z pozitivních faktorů přecházet i do negativních efektů. 
- Jasný a přehledný pohled na organizaci.

- Bezkonfliktní komunikace.

- Rychlé nalezení řešení a rozhodnutí.

- Rychlá implementace inovací.

- Málo formálních předpisů, nižší nároky na kontrolu.

- Vysoká jistota a důvěra spolupracovníků.

- Vysoká motivace.

- Nízká fluktuace.

- Značná identifikace s organizací a loajalita.

- Tendence k uzavrenosti.

- Trvání na tradicích a nedostatek flexibility.

- Blokace nového.

- Kolektivní snaha vyhnout se kritice.

- Vynucování konformity za každou cenu.

- Složitá adaptace nových spolupracovníků.

Z uvedeného výčtu je patrné, že nejnižši položky v silné, ale nezdravé kultuře organizace vytvářejí velké problémy při plánování a realizování změny kultury organizace.

\section{$?$}

Dokážete doplnit tento obecný seznam př́iklady z vaší (pedagogické) praxe?

$* * *$

Jako rozšiřující poznámku k diagnostice kultury školy uvedeme:

Závěry Eger a kol. (2002) a Pol a kol. (2005) se shodují v doporučeních k analýze či diagnostikování kultury konkrétní školy. Každá organizace - škola je jedinečná a kultura je pozorovatelná zejména dle jejích projevů. Některé hlubší roviny (viz pojetí dle Schein) jsou obtižně rozpoznatelné z vně organizace. Kombinací metod včetně hloubkových či skupinových rozhovorů či zúčastněného pozorování máme šanci věrohodněji popsat kulturu organizace. Využití dotazníku a studium dokumentů a artefaktů může sloužit k základní diagnostice. Navíc, jak jsme zjistili z praxe, tam kde je kultura slabá a prípadně i nemocná, je pravděpodobné, že nedostanete úplné a validní odpovědi.

Na závěr k tomuto stručnému přehledu problematiky ve vztahu ke kultuře školy je potřebné uvést několik základních poznámek ke změně kultury organizace. 


\subsection{Změna kultury školy}

\section{? Proč realizovat změnu kultury školy?}

Na základě studia rozsáhlých literárních zdrojů jsme sestavili niže uvedený přehled (Eger, 2006). Kulturu školy je potřebné měnit, jestliže dochází k následujícím okolnostem:

- Vžitá kultura neodpovídá změněným podmínkám v prostředí.

- Dochází k nesouladu s vžitou kulturou a strategicky potřebnou kulturou (změna vize, poslání, cílů a strategie školy, zavádění kurikulární reformy, podstatná inovace ŠVP...).

- S Škola přechází z jedné vývojové etapy do další.

- Dochází k podstatné změně ve velikosti školy (též optimalizace škol).

- Mění se postavení školy na trhu vzdělávání.

- Mění se proto, že se změna očekává (trendy, reformy aj.).

Podíváme-li se na výše uvedený základní výčet, je zřejmé, že od roku 1989 dochází $\mathbf{v}$ ČR neustále $\mathbf{k}$ podstatným změnám $\mathbf{v}$ kultuře našich škol. Otázkou je, zda je řídíme a někdy je možné se ptát, zda o řizení vůbec uvažujeme nebo se o ně snažíme?

\section{!}

\section{Změna kultury organizace není jednoduchou záležitostí a vyžaduje značné úsilí.}

Samožrejmě výchozím bodem je pochopení kultury organizace a zmapování současné kultury. Podstatou změny je přechod od výchozího stavu ke stavu cílovému.

Dále můžeme postupovat dle základní metodiky pro řizení změn (viz i Armstrong, 2007; Řehoř, 2016). Musíme si ovšem uvědomit relativní stabilitu kultury, a tedy i to, že změna ve střednědobém horizontu vyžaduje 3-5 let práce. Co o tom soudíte v souvislosti se zaváděním či další podstatnou inovaci ŠVP ve vaši škole? 


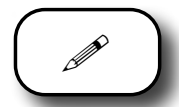

Cesta změny kultury organizace se obvykle uvádí v pěti základních etapách:

1. rozmrazení vžité kultury,

2. tríbení zájmů, postojủ, uvědomováni si souvislostí, príležitostí i hrozeb (také vážení sil, které podporuji změnu a které jsou proti změně),

3. cílené ovlivňování (změna rízení, vzdělávání, informování, odměňování, získávání zkušeností, vytváření nových kulturních vzorů atd.),

4. sladoování změny, korekce chyb, posilováni dosažených pozitivních výsledků,

5. rozvijení žádouciho stavu.

Světlík (2006) ještě speciálně upozorňuje na změnu kultury školy prì generačni výměně ve sboru školy. My naopak dodáme, že k výrazným změnám často dochází i při změně managementu školy.

\section{?}

Jak začít měnit toxickou kulturu školy? (dle Deal \& Peterson, 1999 a 2016). Je potřebné začít s pracovníky a zejména s učiteli. Jak jsme výše uvedli, je to o uznávání společných norem a sdilení hodnot, které jsou uváděny společnou činností v realitu a změna je podporována proaktivním klimatem. Je potřebné podporovat pozitivni aspekty:

- Oslavujete úspěch na setkáních a poradách zaměstnanců a učitelů.

- Používejte príběhy a přiklady o úspěšné spolupráci, kdykoliv je to vhodné.

- Používejte jasný jazyk a profesionální prístup prì podpoře společného učení jak u učitelů, tak i u žáků.

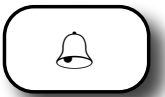

Námět na závěr ke kultuře školy

Jeden z předních odborníků (Barth in Grogan, 2013) v kontextu leadershipu v oblasti vzdělávání a úvah o změně kultury školy upozorňuje na to, že škola existuje proto, aby podporovala vzděláváni svých žákủ. V souvislosti $s$ požadavky zástupců praxe (zde prímo v zastoupení business leaders) upozorňuje na to, že od budoucích zaměstnanců ve firmách v 21. století je 
požadováno, aby měli schopnosti a dovednosti ${ }^{66}$ pro týmovou práci, řešení problémů, interpersonální komunikaci, mluvenou komunikaci, naslouchání, osobní rozvoj, kreativní myšlení, vedení lidí, nastavování cílů, psaní, efektivitu v organizování, v oblasti aplikací ICT a čtení. Zdůrazňuje, že pokud se školy zaměři na krátkodobé cíle, jako je úspěšnost žáků v testech apod., propadnou z hlediska potřebné celoživotní orientace žáků a absolventů škol. Propadnou také v jejich důležitém poslání.

\section{? Kontrolní otázky a úkoly:}

- Objasněte svými slovy podstatu pojmu kultura školy.

- Proč je důležité zabývat se kulturou školy ve vztahu ke strategii organizace?

- Jak můžeme popsat kulturu organizace prostřednictvím manifestace její kultury?

- S jakými projevy silné nebo slabé kultury školy jste se v praxi setkal-a?

- Jaké nadřazené determinanty ovlivňuji kulturu naší školy?

- Co může signalizovat tzv. toxickou kulturu školy a jaká jsou obecná doporučení pro její změnu?

\section{[DD Literatura:}

Světlík, J. (2009). Marketingové rízení školy. Praha: Wolters Kluwer.

Eger, L. (2006). Řizení školy při zavádění školniho vzdělávacího programu. Plzeň: Fraus.

Využito materiálu NiDV: Eger, L., \& Beran, V. (2016) Kultura školy podporující max. rozvoj každého žáka.

Zpracováno v projektu: Strategické řizení a plánováni ve školách a v územích. Informace k projektu na: https://projekty.nidv.cz/strategicke-rizeni

${ }^{66}$ Zvykli jsme si pracovat s pojmem kompetence, stručně znalosti, dovednosti, zkušenosti a motivace pro... 


\section{7 ŠKOLA JAKO ZNAČKA}
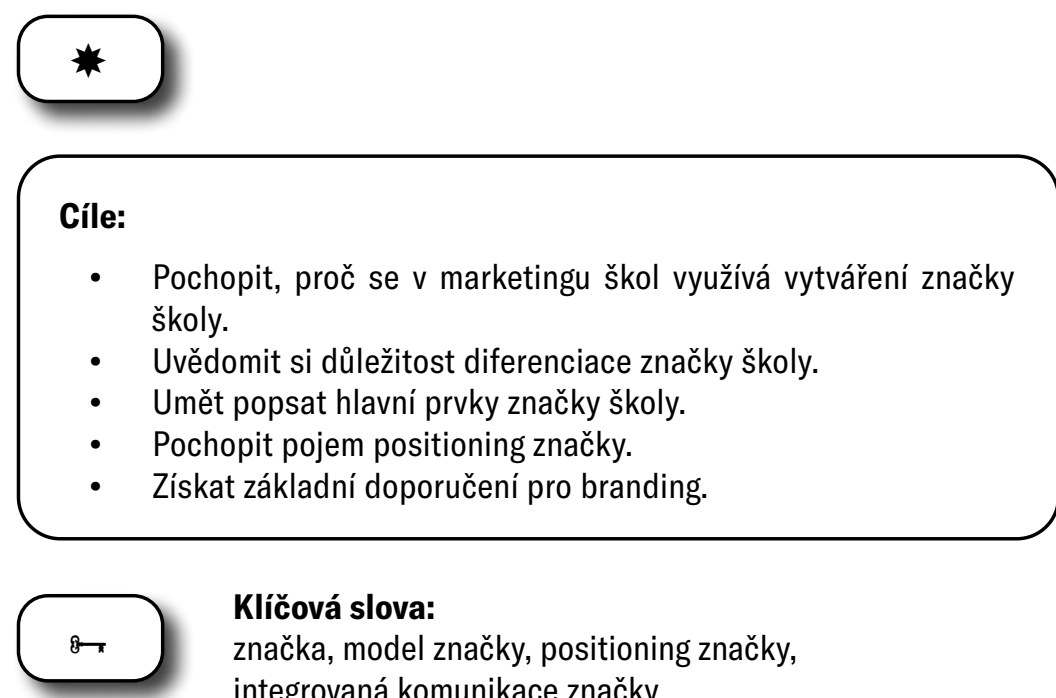

\section{Klíčová slova:}

značka, model značky, positioning značky, integrovaná komunikace značky

Čas potřebný ke studiu základního textu kapitoly je cca 10 minut + možnost rozšírení o studium externích zdrojů $\mathrm{z}$ internetu.

\subsection{Značka}

V našich kurzech pro vedoucí pracovníky škol, a samozřejmě v našich publikacích zaměřených na marketing a management škol, jsme se vždy věnovali tématu image organizace. Problematika značky v oblasti vzdělávání stála jaksi v pozadí, ale je nejvyšši čas to změnit. Současné pojetí marketingu v oblasti vzdělávání staví na tvrzení, že branding ${ }^{67}$ a péče 0 image organizace jsou nezbytnou součástí a náplní efektivního managementu vzdělávací organizace (Lubienski in DiMartino \& Jessen, 2018). ${ }^{68}$

\footnotetext{
${ }^{67}$ Podstatou brandingu jsou činnosti, jejichž cilem je získat požadované postavení značky v myslích jejích zákazniků, tedy vytvořit pozitivní postoje zákazníků ke značce.

${ }^{68}$ Lubienski $(2018$, s. viii) v této publikaci v úvodu doslova uvádi, že změny v oblasti marketingu škol jsou spojené s tím, jak se změnily role lidi, kteři jsou se školami spojeni. Rodiny jsou nyni zákazníci, leadeři škol jsou manažery značek, učitelé a studenti jsou součástí a sehrávaji své role v marketingových strategiích (volně přeloženo).
} 
V následujícím textu proto stručně představíme problematiku z pohledu současného marketingu, kde je již velmi dobře rozpracovaná, a potom ji návazně doplníme 0 aplikace pro vzdělávání se zaměřením na regionální školství. Návaznost na strategii a potom zejména marketingovou komunikaci je evidentní.

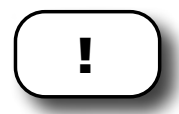

Kotler a Keller (2013, s. 279) uváději: „Marketéři úspěšných značek 21. století musí proces strategického řizení značky bravurně ovládat. Strategické řizení značky v sobě spojuje návrh a implementaci marketingových aktivit a programů budujicích, měřicích a rídících značky s cílem maximalizovat jejich hodnotu. Proces strategického řizení značky zahrnuje čtyři hlavní kroky, k nimž patři:

- určení a zavedení positioningu značky,

- plánování a implementace výkonu značky,

- měření a integrace výkonu značky,

- $\quad$ rozvoj a udržení hodnoty značky pomocí jejího positioningu.“

Pojem „značka“ z hlediska našeho jazyka v sobě skrývá řadu obsahů. $\checkmark$ marketingovém významu představuje značka (brand) ${ }^{69}$ důležitý konkurenční nástroj. Spotřebiteli dobře vnímaná značka jako např́klad Apple, Volvo či Pilsner Urquel přináši společnostem velkou věrnost zákazníků a tím i zisk.

\section{$\square$}

Kotler a Keller (2013, s. 280) definuji značku podle American Marketing Association jako „název, výraz, znak, symbol nebo design či jejich společnou kombinaci, které mají schopnost identifikovat zboží nebo služby jednoho nebo skupiny prodejců a odlišit je od konkurenčních“".

\footnotetext{
Značky identifikuji výrobce nebo dodavatele produktů a umožňují spotřebitelům spojovat tyto produkty s určitými výrobci a dodavateli včetně odpovědnosti za kvalitu těchto produktů. ${ }^{70}$ Vzhledem $k$ tomu, že značka souvisí s image, můžeme uvést, že toto poznání je založeno na minulých i současných zkušenostech se značkou a vzniká na základě objektivních i subjektivních představ, postojů a zkušeností spotřebitele, ale i společností

${ }^{69}$ Bárta a kol. (2009, s. 89) uvádějí, že brand je širši pojem než značka, protože zahrnuje i povědomí o značce, tj. asociace, které se značkou spojujeme - což je ale i podstatou značky, ne?

${ }^{70}$ Foret (2011, s. 199) uvádí, že značka překračuje anonymitu a konkretizuje výrobce a jeho produkt, přispivá tím k jeho vyšši a trvalé kvalitě. Otázkou je, jak je tomu u značek přijimaných jako méně kvalitní, ale za nižši cenu?
} 
$\mathrm{s}$ ní. Značky pro výrobce či dodavatele plní funkce $v$ oblasti manipulace s produkty, ochrany jejich specifik. ${ }^{71}$ Důvěryhodná značka je vždy spojovaná s určitou úrovní kvality. Značka také dokáže navodit personifikovaný vztah $s$ relevantními cílovými skupinami, a to je důležité i pro oblast školství.

Značka je slib, který poskytujeme každému ve škole a těm, kteří mají zájem o naši školu: rodinám a jejich dětem = našim žákům, učitelům a dalším pracovníkům školy, komunitě, zřizovateli a dalším podporovatelům školy... (upraveno dle DiMartino \& Jessen, 2018).

\section{!}

Při prezentovaní tohoto slibu řekněte lidem: „To je to, co od nás můžete očekávat.“

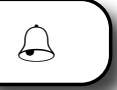

Značka podle Karlička a kol. (2013) není pouhou nálepkou, ale je nositelkou určitého významu, zvyšuje vnímanou hodnotu, zaštituje produkty a komunikuje zákazníkům jejich diferenciaci, ale také důvěryhodnost a vytváří přitažlivost spotřebitelů. Vše, co je uvedeno v předešlé větě, je dnes klíčově důležité pro školu a její komunikaci s veřejností.

Značkový produkt (včetně služby v oblasti vzdělávání) je tedy diferencován od jiného produktu, jenž je zaměřen na uspokojení stejné či podobné potřeby. Tato diferenciace je v oblasti vlastností (užitků) produktu, ale i v racionálním a emocionálním přijímání značky a také v dalším abstraktnějším nehmotném odlišení.

\section{!}

Diferenciace značky školy od ostatních ji také činí rozeznatelnou.

„Značka není pouhý produkt. Produkt se vyrábí, značka se vytváŕi. Produkt se v čase mění, značka zůstává.“ (Bárta a kol., 2009, s. 88)

${ }^{71}$ Může se jednat o ochranné známky, patenty, autorská práva ve vztahu k designu produktu i obalů atd. 
Produkt Ize popsat objektivně dle určitých charakteristik, jeho značka souvisí i s atributy image, tedy vytvořeného obrazu u relevantních skupin veřejnosti (skupiny spotřebitelů, ale i prostředníků, prodejců, též konkurence atd.). Dokonce můžeme uvést, že právě konkurence a výskyt jiných produktů uspokojujících stejnou nebo podobnou potřebu pomáhají značce získat jeji identitu. Platí to opět i pro školství, viz další text.

Pokud výše uvedený odstavec aplikujeme napřiklad na střední školu, tak to u relevantních skupin budou: její studenti, také učitelé a další pracovníci, rodiče, firmy, kam odcházejí absolventi, konkurenční SŠ, také navazující fakulty VŠ, ale i subjekty veřejné správy a specificky i ČŠı či Úřad práce atd. Dále zvažte, že například ZŠ vycházejí z RVP, ale jejich ŠVP (včetně prezentace těchto programů) se i značně liší. Podobně, existuje řada středních škol se stejným či podobným zaměřením, se kterými je právě ta vaše porovnávána a tím dochází $\mathrm{k}$ její identifikaci jako značky právě u těch důležitých cílových skupin.

$Z$ teorie marketingu také víme, že značky můžeme různě členit. Do hierarchického členění na nejvyšši úrovni řadíme firemní či korporátní značku, následují deštníkové značky, individuální značky, a nakonec značky konkrétních modelů produktu. Uvedené členění v kontextu školství v ČR nebudeme aplikovat pro MŠ a ZŠ, ale zajímavé již může být pro větši střední školy, jež poskytuji vzdělávání ve více studijních programech, ale i pro ZUŠ či DDM, kde také pod „korporátní značkou“ můžeme sledovat a hodnotit dílči značky např́klad pro různé kroužky nebo prázdninové aktivity atd.

\section{(:)}

Mezi významné prvky značky patří nejenom její jméno ${ }^{72}$ logo, symbol, slogan, popěvek, maskot, ale také design www stránek a materiálů (u firem obalů, zde studijních materiálů apod.), dnes i tvář = představitel značky. ${ }^{73,74} \mathrm{~S}$ tím vším v současné době již řada škol také pracuje.

\footnotetext{
${ }^{72}$ U názvu vše začiná (Vysekalová \& Mikeš, 2018), měl by být stručný, jedinečný a neopakovatelný. Nicméně, název školy již v naprosté většině př́padů neovlivníte.

${ }^{73}$ Před 25 lety jsme s kolegyní Jakubíkovou v prvních seminářich pro vedouci pracovníky škol o této problematice mluvili a uváděli i přiklady ze zahraniči ze západních zemí. Mnozí kroutili hlavami...

${ }^{74}$ Belch a Belch $(2021$, s. 13) pracuji s pojmem identita značky, jež je kombinaci řady faktorů včetně jména, loga, symbolů, designu, obalu a výkonu produktu nebo služby, stejně jako image nebo druhu asociací, jež se zákazníkủm vyjevi v mysli, když přemýšleji o značce.
} 


\subsection{Hodnota značky}

Jedná se o hodnotu, kterou značka přidává produktům a obvykle se odráží v tom, jaký vztah spotřebitelé ke značce maji (jak ji vnímají a jak ve vztahu k ní jednají) a potom i v ceně, a nakonec i v zisku, který přináší.

\section{!}

„Síla značky spočívá v tom, co o ní v průběhu času zákazníci četli, viděli, slyšeli, zjistili, mysleli si a cítili.“" (Kotler \& Keller, 2013, s. 281)

Značka může mít pozitivní, ale i negativní hodnotu, která je z pohledu zákazníka udělována jeho vnímáním produktu, jenž značka prezentuje, při srovnávání s podobnými produkty. Hodnota značky tedy vychází zejména $z$ rozdílů v reakci spotřebitelů, jež jsou budované na základě spotřebitelovy znalosti značky (príslib značky) a to se potom odráží v preferenčním chování spotřebitelů při nákupu produktů, tedy například i při výběru školy a jejího programu či kroužku pro děti atd.

\section{Model značky}

Existuje samožrejmě více modelů značky. Pro náš účel volíme dva velmi známé a stručně je představujeme níže.

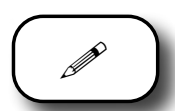

Velmi známý je tzv. Aakerův model (viz Kotler \& Keller, 2007), který se dívá na hodnotu značky jako na soubor aktiv a pasiv spojených se značkou. Aaker považuje za velmi důležitou identitu značky, jež se sestává z následujících hledisek, která upravujeme v aplikaci pro regionální školství:

- Značka jako vzdělávaci služba (účel vzdělávacího programu, vlastnosti tohoto programu, jeho kvalita/hodnota, využití pro hlavní cílové skupiny, uživatelé vzdělávací služby, spojení s městem a regionem v kontextu ČR).

- Značka jako škola (vlastnosti školy, lokální kontext, ale dnes i v globálním pohledu, minimálně tedy kontextu EU).

- Značka jako osoba (osobnost značky, vztah značky školy a jejích zákazníků).

- Značka jako symbol (vizuální metaforika a odkaz značky). 
Zmíněný model hodnoty značky z pohledu spotřebitele člení soubor výhod (aktiv) a nevýhod (pasiv) do čtyř kategorií, které uvedeme opět ve stručné aplikaci pro školy:

- Povědomí o značce znamená to, do jaké míry je značka „umístěna“ v mysli spotřebitele. Je to velmi důležité (základ) pro budování nové značky. Zvažte: Jak zástupci vašich cílových skupin rozpoznávají vaši školu jako značku, když se s ní znovu setkaji (identifikace značky)? Dokáží si ji vybavit, když s dalšími lidmi diskutují o vzdělávání žáků na př́slušném stupni studia či ve vašem regionu (vybavení si značky)?

- Asociace se značkou. Asociace se mohou v paměti spojit v jedinečné, silné a pozitivní vzpomínky spojené se značkou, vedou k celkovému posílení hodnoty a image značky. Jejich vytvoření je nejčastěji spojeno s osobní zkušeností, při které se vytvárí nejvíce informaci o subjektu, a ty vedou $k$ nejsilnějším asociacím o vlastnostech a prínosech značky. Dalši možností je tzv. ústní podáni (doporučení), kdy spotřebiteli značku doporuči prátelé, rodina nebo jiný subjekt, který je nezávislý a důvěryhodný. Dnes zde významnou roli sehrává tzv. eWOM a komunikace v komunitách s využitím sociálních médií. Uvádí se, že nejslabší asociace se značkou vytvárí reklama, na druhou stranu mohou ale být tyto asociace touto cestou nejsnáze měněny. Asociace se mohou v paměti spojit v jedinečné, silné a pozitivní vzpomínky spojené se značkou školy, vedou $k$ celkovému posílení hodnoty a image školy.

- Vnímání kvality. Vnímaná kvalita vzdělávacího programu souvisí s asociacemi se značkou. Aaker ji považuje za samostatnou kategorii. Přes různé marketingové strategie nesmí managementy škol z pohledu marketingu nikdy zapomínat na kvalitu jejich produktu. Silná značka školy musí zároveň nabízet i kvalitu vzdělávací služby. Bez kvality ve vzdělávací oblasti si škola žádnou značku s vysokou loajalitou a hodnotou nevybuduje. Nicméně je také potřebné dát o této kvalitě vědět, což je úlohou integrované marketingové komunikace. Někdy musíme naučit spotřebitele (žáky, rodiče...) kvalitu vnímat. Na druhou stranu vedení školy se musí vyznat v tom, co zákazníci / klienti považují za kvalitní a potřebuje pochopit, jak kvalitu cílové skupiny vnímají.

- Loajalita ke značce. V Aakerově terminologii věrnost (loajalita) přináší značce přiznivce, kteři se naučili tuto konkrétní značku nakupovat, a tím zvyšují hodnotu značky (pro jejího majitele). Vysoké povědomí spolu s vysokou úrovní asociace vedou $k$ preferenci, a tedy k loajalitě zákazníků. $V$ našem případě zejména rodin, kdy například po rodičích i děti absolvuji stejné školy, nebo po starším sourozenci i mladší nastupuje na školu, jež je vnímaná jako pozitivní značka. 


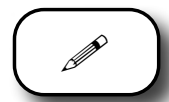

Dále představíme model rezonance značky (Kotler \& Keller, 2013), který dobře vyjadřuje psychologické aspekty značky ve vazbě na zákazníky a zobrazuje na jedné straně racionální cestu $k$ budování značky a na straně druhé emocionální cestu. To považujeme za vhodný podnět právě pro účel komunikace značky.

$* * *$

„Model rezonance značky se také dívá na budování značky jako na řadu postupných kroků seřazených od spodu nahoru: 1. zjištění, že zákazníci značku poznaji a spoji si ji s určitou třídou výrobků nebo potřebou, 2. značka je v myslích zákazníků volně zakotvena pomocí strategického navázání rady hmotných i nehmotných asociací, 3. vyvoláni odpovídající reakce zákazníka ve smyslu hodnocení a pocitů týkajících se značky, 4. přeměna reakcí zákazníka na intenzivní, aktivní věrnost.“" (Kotler \& Keller, 2013, s. 284) Přitom vytvoření podstatné hodnoty značky vyžaduje dosažení niže prezentované pyramidy a $\mathrm{k}$ tomu podle tohoto modelu dochází jen v prípadě, že zobrazené bloky pyramidy dobře zapadnou na své místo.

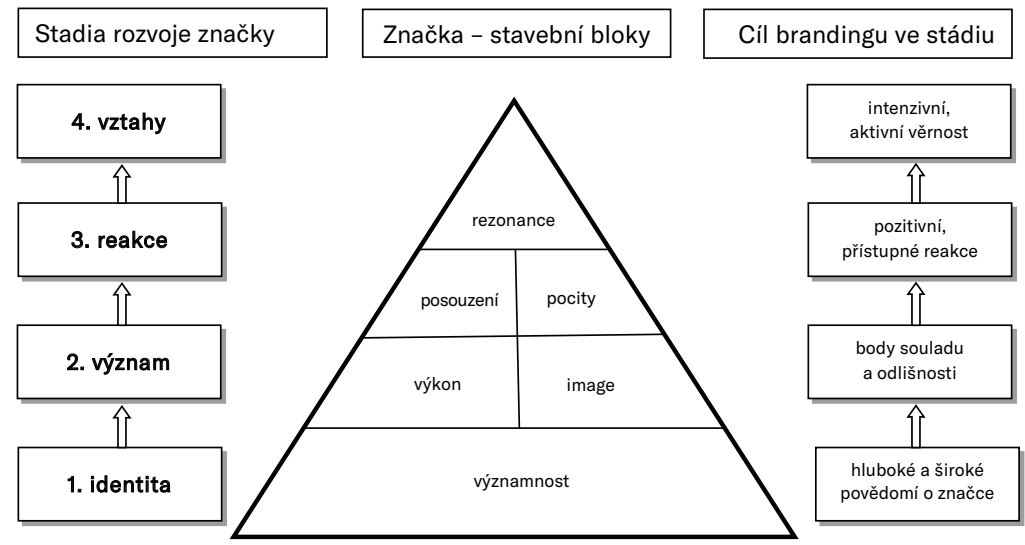

Obrázek 14: Pyramida rezonance značky, podle Kotler a Keller (2013, s. 287)

Jednotlivé stavební bloky znamenaji (připojujeme stručně aplikace):

- Významnost značky = jak často a jak snadno si zákazníci na značku vzpomenou v nejrůznějších kupních nebo spotřebních situacích. 
V našem případě např. když diskutují se svými přáteli a známými o vzdělávání dětí, jejich přihlášení do kroužků apod.

- Výkon značky = jak dobře produkt uspokojuje funkční potřeby zákazníků. Vede např. absolvování této základní školy $\mathrm{k}$ úspěšnému přijetí na školu střední, nebo tohoto gymnázia $k$ tomu, že se student úspěšně dostane na univerzitu?

- Image značky = vnější vlastnosti produktu ve smyslu způsobu uspokojování psychologických a společenských potřeb zákazníků. Jsou žáci a studenti, ale i jejich rodiče..., hrdí na to, že jsou absolventy školy?

- Posouzení značky = osobní názory a hodnocení zákazníků. Dnes nejenom jak se o škole mluví v obci či regionu, ale i jak na sociálních sítích?

- Pocity spojené se značkou = emoce souvisejíci se značkou. Nejsilnější maji žáci a jejich učitelé a některé školy jsou v emočním naladění této komunity opravdu velmi dobré!

- Rezonance značky = vztah, jež zákazníci se značkou mají, pocit spjatosti se značkou.

\section{!}

Budování hodnoty značky souvisí s vytvářením kontaktů zákazníků se značkou a s positioningem značky (jejím umístěním $v$ jejich mysli).

Na tom se podíleji tři hlavní skupiny faktorů (Kotler \& Keller, 2013):

1. Prvky identity tvořící značku (názvy, webové adresy, loga, symboly, postavy, reklamní tváře, slogany, znělky, balení).

2. Výrobek (vzdělávací program - naše poznámka) a všechny doprovodné marketingové aktivity a podpůrné marketingové programy.

3. Ostatní asociace neprímo přenášené na značku pomocí vazeb s dalšími entitami (osobou, místem, věcí).

A zde se již opět dostáváme ke zdůraznění toho, že kličová pro budování značky je integrovaná marketingová komunikace. Určitou podmnožinou je potom návrh brandingové strategie, tj. architektury značky a připadně spravování portfolia značek školy. 


\subsection{Realizace positioningu a komunikace značky}

Obecně můžeme uvést, že využívání značky, která je dobře vnímána spotřebiteli, stojí na jeji dobře diferencované pozici v jejích myslích. Musí uspokojovat jejich potřeby a prání. Úkolem integrované marketingové komunikace je jim nejenom prezentovat očekávanou kvalitu při poskytování hodnoty, ale dát i něco navíc.

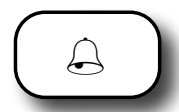

U podnikatelských subjektů platí, že trh je velmi konkurenční, a proto základem je positioning značky. V kontextu našeho regionálního školství jsou vzdělávací služby realizované na regulovaném trhu a, jak jsme již uvedli dřive, jsou zde velké odlišnosti v postavení subjektů MŠ přes ZŠ až po SŠ na tomto trhu. Nicméně, i školy, které v svém kontextu necití tak silný tlak trhu, by dále měly využít poznatky z tržního prostředí. Zcela jistě je to bude lépe pro- aktivně motivovat ke komunikaci své školy jako značky. ${ }^{75}$

Kotler a Keller (2013) za výchozí bod považuji definování referenčního rámce konkurence a pracuji s body shody a body odlišnosti, jež si spotřebitelé spojuji se značkou (asociace spotřebitelů). Na základě analýzy doporučuji vytvářet percepční mapy a hledat mantry značky (srdce značky), jež jsou středem terče positioningu.

Na tomto základě jsou vytvářeny diferenciační strategie, které by se měly opírat o konkurenční výhodu pro zákazníka. Diferenciace je potom spojena nejenom $s$ vlastnostmi produktu, ${ }^{76}$ ale i personálu, $s$ použitých distribučních kanálů, s vytvářením image a s tím, co můžeme zahrnout do rozšířeného produktu. ${ }^{77}$ Pro školství to znamená: vlastnosti vzdělávacího programu, kompetence, ale i image zejména učitelů, ale i dalšího personálu, místo školy a její dostupnost, ale i aplikace ICT na podporu vzdělávacího procesu..., pozitivní obraz školy u relevantní veřejnosti, nabídka dalších vzdělávacích aktivit a služeb školy.

V návaznosti se také diskutuje tzv. emocionální branding, také kulturní branding nebo vytváření přiběhů nebo historek 0 značce ${ }^{78}$ atd.

\footnotetext{
${ }^{75}$ Navic, v zahraničí je to skutečně trend v marketingu škol (viz. např. DiMartino \& Jenssen, 2018).

${ }^{76}$ Zajímavé je, že ve vydání z roku 2007 (Kotler \& Keller) je významná pozornost věnovaná i životnímu cyklu produktu. Pozor i vzdělávaci program má svůj cyklus.

${ }^{77}$ Kotler a Keller (2013, s. 326) zde mluví o službách a spolehlivosti, odolnosti a inovativnosti.

${ }^{78}$ Př́klady: zadejte si do Youtube „university history story“ a podivejte se pro inspiraci napřiklad na Oxford, Standford, Cambridge nebo Harvard. Mǔžete dosadit i „grammar school“ a pokračovat...
} 


\section{!}

Foret (2011) uvádí, že pro budování značky a jeji životaschopnost jsou důležité následující aspekty:

- Diferenciace - značka se musí odlišovat.

- Relevantnost - musí mít význam pro zákazníky, ale také odpovídat vlastnostem produktu.

- Prestiž - je závislá na kvalitě a oblibě produktu.

- Znalost - lepší maji pochopitelně zavedené značky.

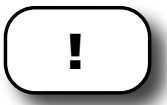

Pro komunikaci značky a jeji positioning je důležitá, jak jsme již uvedli výše, esence značky, která je jejím nezaměnitelným základem. Představuje nitro hodnoty značky, duši osobnosti značky a jeji vizuální identitu (Bárta a kol., 2009). Pro marketingovou komunikaci je potom důležité sledovat další pojem, tj. tzv. „insight značky“, jenž představuje vztah mezi značkou a životem spotřebitele a je potřebné jej sledovat kvalitativními prístupy v kontaktu se zákazníky (pozorovat, naslouchat, vést dialog...). Je to nesmírně důležité právě i pro komunikaci školy s veřejností.

Z hlediska marketingu na internetu a využívání ICT je důležitá poznámka Kotlera a Kellera (2007, s. 322) o personalizaci značek jako o odlišném přistupu od masového marketingu, kdy nyní jde spiše o prístup one-to-one. Více se o tom zmíníme v kapitole věnované marketingu na internetu.

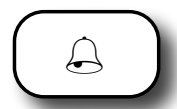

Zvažte následující tvrzeni: Značkové myšlení učí, že značky jsou vytvořené komunikací a jsou tedy nehmotné. Mají ale sílu „vytvořit realitu“ a ovlivňují spotřebitele a produkty, jež by měly být chápány jako „efekt“ značky. Důležité je si uvědomit, že komunikovat značku znamená komunikovat identitu (viz i Bárta a kol., 2009). ${ }^{79}$

${ }^{79}$ Pro zájemce k tomu více v nové publikaci Vysekalová a kol. (2021). 
Alternativně Pelsmacker a kol. (2003, s. 75) považují za hlavní úkol marketingové komunikace sdělovat podstatu osobnosti značky ${ }^{80}$ a trvale udržovat partnerství mezi značkou a zákazníkem, a přitom zdůrazňují potřebu dlouhodobé konzistence marketingové komunikace pro budování značky.

- Značka školy rozhodně není budována jen reklamou. Důležitý je kontakt relevantní veřejností se značkou, tj. vlastní vzdělávací proces, třídní schůzky, žákovský parlament, rada školy, klub či sdružení přiznivců, eventy spojené se školou, veletrhy vzdělávání, spolupráce se sponzory, zapojení do projektů, PR aktivity aj.

- Důležité je i navázání na tzv. sekundární asociace, tedy vytváření hodnoty pomocí navázání i na tradice a jiné informace $v$ myslích spotřebitelů, navázání na jiné zdroje a hodnoty. Př́kladem je zapojení škol do dalších vzdělávacích, kulturních, ekologických aj. aktivit v regionu a v obci.

- Dalši důraz se dnes klade na tzv. interní brandig (zaměření na rozvoj a spolupráci se zaměstnanci) a tvoření komunity značky např́klad i na sociálních sitích.

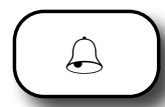

Značka by měla usilovat o pocit výjimečnosti pro spotřebitele, v našem prípadě pro ty hlavní cílové skupiny školy. Je nutné využívat sdílení hodnot, zážitků, zapojování všech relevantních aktérů do aktivní podpory image a značky školy. Trendem je vytváření komplexnějších komunikačních kampaní a jejich propojování v různých médiích, tedy přistup TTL, který si objasníme v další kapitole.

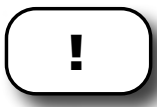

Silná značka školy s sebou nese věrnost jejích vnitřních (např. učitelé a žáci) i vnějších zákazníků (rodiče, další školy nebo organizace, obec aj.). Je ovšem postavena na kvalitním produktu, zde zejména vzdělávacím produktu a jeho skutečné realizaci, bez něj nelze značku utvořit a ani udržet.

\footnotetext{
${ }^{80}$ Značky - aktivita a jen fyzická podoba a pozice na trhu nestači. Je nutné přidat tzv. sociální chování značky = budou se vymezovat více lidsky, čestně, nebudou zastírat své nedostatky, budou pracovat se skutečnými emocemi, sympatií, pokorou, štědrostí - značky s lidskou tváři. (Barčik, 2012, s. 7).
} 


\section{Branding}

V závěru této kapitoly ještě stručně objasníme pojem „branding“. Kotler a Keller (2013) uvádí, že branding představuje spojení produktů a služeb se značkou. Branding podle současných prístupů spojuje 5 prvků:

- positioning,

- príběh,

- design,

- $\quad$ cenu $^{81} a$

- vztah se zákazníkem.

Obecně má 3 cíle: posilovat známost značky, budovat sympatie ke značce a zdůrazňovat její odlišnost (diferenciace). Podstatou brandingu jsou činnosti, jejichž cílem je získat požadované postavení značky v myslích jejích zákazníků - tedy vytvořit pozitivní postoje zákazníků ke značce.

Podle DiMartino a Jessen (2018, s. 74) je vytváření značky proces s řadou kroků. Začíná s formulováním mise a vize organizace a končí prezentováním značky prostřednictvím jejích vizuálních prvků (například sem řadí logo, uniformy ${ }^{82}$ - není typické pro naše školy) a cílenou reklamní kampaní, která je zaměřena na specifické komunity a cílové skupiny veřejnosti.

Branding ve školství se také poměrně silně vztahuje $k$ tomu, jak je hodnoceno fyzické prostředí školy či její materiální zázemí a vybavení. I v našem kontextu je vybavení škol a tříd významnou vizuální součástí značky školy.

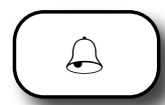

Do diskuse dáváme následující tvrzení. Jakou úlohu v souvislosti se značkou školy hraje její vizuální stránka (od loga až po vybavení budov a tříd) a jakou zaměření na vzdělávací program a zlepšování v pedagogické oblasti. Dále, jakou roli hraje zaměření na aktuální výstupy vzdělávacího procesu, proti zaměření na celoživotní učení, výchovu k občanství, zvládání diverzity atd..$^{83}$

\footnotetext{
${ }^{81}$ Vzpomeňte si na vyjádření ceny v marketingu, zejména ve školstvi to není jen o penězích.

${ }^{82}$ Nicméně známe využiváni triček s logem školy apod.

${ }^{83}$ Opět s odkazem na DiMartino a Jessen (2018, s. 18-19).
} 


\section{? Kontrolní otázky a úkoly:}

- Co je to značka z pohledu marketingu?

- Proč používat značky i v oblasti vzdělávání?

- Dokážete svými slovy popsat pyramidu rezonance značky?

- Vyjmenujte prvky značky vaši školy, které z klasických zatím nepouživáte?

- Na co se musíme $v$ marketingové komunikaci zaměřit $\mathrm{z}$ hlediska značky školy?

미 Literatura:

Kotler, P., \& Keller, K. L. (2013). Marketing management. Praha: Grada.

Vysekalová, J., Mikeš, J., \& Binar, J. (2020). Image a firemní identita. Praha: Grada. 


\section{IMAGE ŠKOLY}

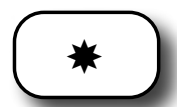

\section{Cíle:}

- Uvědomit si úlohu duležitosti péče o image školy.

- Pochopit problematiku utváření image školy u relevantní veřejnosti.

- Umět popsat doporučené postupy průzkumu image školy.

- Diskutovat základní strategie komunikace image školy.

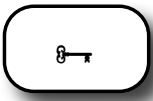

\section{Klíčová slova:}

image školy, schéma image organizace, autoevaluace, plán komunikace image

8

Čas potřebný ke studiu základního textu kapitoly je

cca 15 minut + možnost rozšiření o studium externích zdrojů

$z$ internetu.

\section{Úvod}

Mezi nejdůležitější úkoly marketingové komunikace a v tom Public Relations pro neziskové organizace (tzn. i školy) patři šíření dobrého jména, budování přiznivé image a dlouhodobých vztahů s širokou veřejností.

Jak si dále ukážeme, téma je spojeno s vizí, misí, strategickým plánováním a kulturou školy, a predevším s komunikací školy s veřejností. Problematice jsme se od roku 1999 věnovali v několika odborných studiích a naše studijní materiály ${ }^{84}$ i metodické postupy již byly aplikovány na řadě škol v České republice i na Slovensku. Z hlediska současného pojetí marketingu školy potom téma souvisí se značkou školy, viz předešlá kapitola.

\footnotetext{
${ }^{84}$ Studijni text Eger a Egerová (2001) Image školy, dostupný článek k tématu najdete i na www.rvp.cz a vědecký článek zaměřený na evaluaci image školy (Eger, Egerová, \& Pisoňová, 2018) je potom dostupný v časopise Center for Educational Policy Studies Journal také na internetu.
} 


\subsection{Co rozumíme pod pojmem image školy?}

Např́klad v metodice pro vzdělávání ředitelů škol v Polsku (Dzierzgowska, 2000) bylo v úvodu k tématu obraz firmy napsáno: každá firma, každá instituce, vědomě nebo nevědomě vytváři určitý obraz. A jestliže tomu tak je - potom je lepší to provádět cíleně a profesionálně. I takto může být stručně řečeno, proč je pro management škol důležité zabývat se image instituce.

Podle Bernstein (1984) můžeme uvést, že image organizace je tvořena nesčetnými detaily. Jedná se ale o celkový dojem, jež vyplývá z mozaiky syntetizované z mnoha dojmů vytvořených jako prímý nebo neprímý výsledek různých formálních nebo neformálních signálů vycházejících z organizace. Image školy (také její pověst) představuje nebo popisuje způsob, jakým jsou školní aktivity a jeji studijní program vnímány veřejností. Jsou to pocity a přesvědčení o škole a jejím programu v myslích veřejnosti. Jedná se o souhrnný psychologický dojem, který je založen na minulých a současných, pravdivých a falešných zkušenostech a informacích týkajících se školy.

Dále je potřebné si uvědomit, že velká škola nemá pouze jedenu společnou image organizace. Každý studijní program má svůj vlastní obraz, který může být i odlišný od celkového. Vždy se to týká relevantni veřejnosti.

Pro vzdělávací subjekt používáme následující specifickou definici image:

\section{$\square$}

Image je souhrn všech představ, poznatků a očekávání spojených s daným vzdělávacím subjektem, s učiteli nejen současnými, ale i s bývalými, se studenty nejenom současnými, ale i s absolventy a jejich předpokládanými znalostmi. (Štefko, 1999)

Image je výsledkem prezentace, respektive vnímání prezentace školy veřejností. Image představuje určitou zkratku hodnocení školy a skládá se z objektivních i subjektivních, správných, ale i nesprávných představ, postojů a zkušeností jednotlivce a skupiny lidí o určité škole nebo vzdělávacím programu. Prochází vývojem, je měřitelná a přes určitou stabilitu je i ovlivnitelná $\checkmark$ rámci dlouhodobé koncepce.

Image školy je utvářena její identitou, kulturou školy a podstatný vliv má i design a nejdůležitější produkt, tj. vzdělávací program či vzdělávací programy školy. Vše dotvárí a obklopuje komunikace, a to jak marketingová (v tomto smyslu řízená), tak i neřizená, jež můžeme více spojit s WOM. Pro objasnění 
obsahu image a vztahu mezi jejími jednotlivými složkami můžeme vyjít ze vzorce, který uváděl Němec (1996) a který níže propojujeme v inovovaném schématu v obrázku 15.

\section{I $(\mathrm{CD}+\mathrm{CC}+\mathrm{Cl}) \cdot \mathrm{CCom}=\mathrm{Cim}$}

Jednotlivé složky znamenají (uvedeno pouze informativně a stručně):

- $\quad \mathbf{C D}=$ corporate design, firemní způsob, jakým se organizace představuje veřejnosti.

Design školy je vizuálně vnímatelné ztvárnění artefaktů školy. Patří sem architektura a stav budov včetně okolí školy, vnitřní vybavení nejen tříd, ale i sboroven, knihovny, tělocvičny, vrátnice atd. Oblečení zaměstnanců, případně i studentů, orientační a propagační materiály školy, logo, www stránky školy, úprava studijních materiálů, tiskovin, dopisů apod.

- $\quad \mathbf{C C}=$ corporate culture.

Kultura školy má svoji materiální i nemateriální manifestaci, a to směrem dovnitř i navenek a tím samozřejmě významně přispivá $k$ vytváření image školy u relevantní veřejnosti. Podrobněji viz kapitola 6 o kultuře školy.

- $\quad \mathbf{C l}$ = corporate identity, jedná se o filosofii organizace, také o zosobnění se $s$ ní.

Identita školy je jeji filosofií, vzniká stanovením kompetencí a vytvořením podvědomí jak uvnitř školy v mysli každého jejího pracovníka, tak vně školy, u veřejnosti o tom, oč škola usiluje, kam se ubírá, čeho chce dosáhnout, jak vidí sama sebe. ${ }^{85,86}$

Identitu školy můžeme definovat jako určitou představu, kterou má škola (lidé s ní spojení) o sobě samotné, což v tomto smyslu je velice podobné tomu, jakou má člověk představu o vlastní osobnosti. Vykydal (2000) kromě historie, predstav a filosofie upozorňuje i na důležitost osobnosti vedení i ostatních lidí v organizaci, ale také na etické a kulturní hodnoty a strategii.

- $\quad$ CCom = corporate communication, komunikace, která využívá všech komunikačních kanálů a jejích prostředků a je kličová pro realizaci Public Relations.

Komunikace školy s veřejností - viz zejména kapitoly 8 a 9 .

\footnotetext{
${ }^{85}$ Srovnej s informacemi o vizi a s potřebou akceptace vize, získáním učitelů a studentů pro vizi školy s cilem identifikace s ni!

${ }^{86}$ Nejpodrobnějši rozpracování problematiky identity a image najdete v publikaci Vysekalová a kol. (2020).
} 


\section{$\square$}

Předchozí pojednání o složkách obsahu image Ize zjednodušeně znázornit v následujícím schématu, kde identita je základem (filosofií) a image je výsledným obrazem.

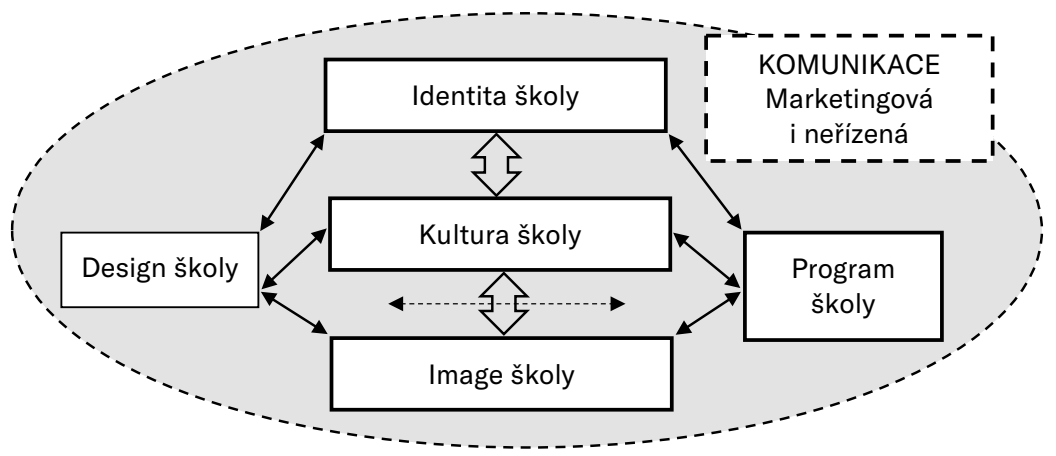

Obrázek 15: Schéma image školy

Jednotlivé složky nelze od sebe oddělovat, prostupuji se a ovlivňuji. Komunikace přesahuje i uvedené schéma.

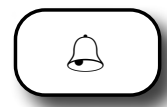

V marketingu pro vzdělávací organizace zařazujeme pod pojem produkt zejména vzdělávací program. Zvažte ovšem, že máme plánované a realizované kurikulum a také formální a skryté. To vše se promítne v obrazu (v image školy) tak, jak si jej utváří relevantní veřejnost, tedy např. učitelé, žáci, rodiče...

\subsection{Autoevaluace image školy}

Pro vzdělávací instituci se stává životně důležité sledováni toho, jak se na ni veřejnost dívá, jaké má o ní představy a jaké očekávání spojuje s realizací jejího vzdělávacího programu a dalšími službami, které nabízí.

Přiznivá image školy má velký význam a je v této souvislosti nutné si uvědomit, že image vzdělávacích institucí bývá relativně stabilní a nelze ji rychle měnit změnou strategie vztahů s veřejností. Management školy musí počitat s tím, 
že lidé reagují na vytvořenou image školy u určité veřejnosti, která nemusí mít vždy reálnou představu o současné realitě v konkrétní škole. Celé téma souvisí s vnímáním hodnoty školy, kterou škola poskytuje a ta je spojena s kvalitou školy a vynaloženou celkovou „cenou“, stejně jako s komunikací školy s veřejností. ${ }^{87}$

\section{Zvažte:}

- Zejména pro střední a vysoké školy je důležité si uvědomit, že analýzou image školy můžeme stanovit také tržní pozici školy při srovnávání image konkurenčních škol, respektive pozici, jakou škola zaujimá v mysli svých potenciálních zákazníků. Prestiž školy je jedním z rozhodujících faktorů pro rozhodování zájemců o studium. Dostatečný počet zájemců je potom předpokladem pro získávání finančních zdrojů pro instituci.

- Můžeme poznat silné a slabé stránky instituce a doplnit tak např. SWOT analýzu školy o další pohled = hodnoceni obrazu školy skupinami respondentů.

- Rozbor pohledů jednotlivých skupin respondentů na školu je velmi důležitý pro stanovení strategie následné komunikace vůči cílené skupině. Zvyšuje se tím rovněž efektivita další činnosti managementu školy v této oblasti.

- Opakovaná analýza potom samozrejmě zachycuje změny v image instituce a slouži pro vyhodnocení použité strategie.

\section{Komplexní práce s image instituce je součástí marketingových aktivit a je nemožná bez znalostí základních poznatků o image organizace.}

Tématu image školy se věnuje velká pozornost ve studijních materiálech pro managementy škol v Anglii (např. Fidler, 2002) odkud jsme čerpali inspiraci i pro ČR. Napřiklad Brent a Ellison (1997) v marketingu školy př́mo vybízeli k přezkoušení image své školy (volně přeloženo):

„Je potřebné znát jaké jsou pohledy klientů na základní silné a slabé stránky školy. Klienti v různých tržních segmentech (včetně učitelů) maji odlišné pohledy, které je potřebné znát, jestliže má být projektována image školy.“

${ }^{87}$ Dnes navic v zaměřeni na prezentováni školy jako značky. 


\section{Metody měření image školy}

Autoři Světlík (1996), Štefko (1999) a Eger a Egerová (2001) popisují následující základní možné metody měření image školy:

- měření známosti a přiznivosti postojů $\mathrm{k}$ dané instituci,

- $\quad$ sémantický diferenciál - měření polohy image instituce na základě hlavních, tzv. relevantních dimenzí,

- vícefaktorová metoda,

- multidimenzionální analytická mapa.

\section{(:) Námět pro praxi}

Pro praktické použití, které je realizovatelné vzhledem k obvyklým možnostem škol, jsou vhodné především první dvě metody. Navíc, máme s využitím průzkumu image školy pro autoevaluační účely velmi dobré zkušenosti. ${ }^{88}$

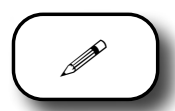

\section{Měření známosti a přiznivosti postojů $\mathbf{k}$ dané instituci}

Metoda slouži pro zjištování dvou hlavních údajů u každé dotazované cílové skupiny. Prvním dotazem zjištujeme míru známosti sledované instituce a druhý dotaz pokládáme jen respondentům, kteři instituci znají, a zjištujeme stupeň přizně. Následuje popis metody:

\section{A. míra známosti instituce (povědomí o škole)}

Př́klad otázky: Znáte školu xy? nebo: Co víte o škole xy?

První otázka šetření nás informuje o tom, zda veřejnost, respektive cílová skupina o uvedené škole ví (vlastně se jedná o stupeň povědomí).

Pro vyhodnocení můžeme použít následující pětistupňovou škálu:

1. neznám, nikdy jsem o ní nic neslyšel,

2. slyšel jsem o ni jen něco,

3. znám ji,

4. vím o ní poměrně hodně,

5. znám ji velmi dobře.

\footnotetext{
${ }^{88} \mathrm{~V}$ případě střední školy se jednalo dokonce o využití v rámci SOČ. Na základní škole to byl průzkum realizovaný žáky deváté třidy pod vedením učitelky. Samožrejmě zcela běžně téma využiváme v poradenské činnosti $\checkmark$ kooperaci s vedením školy, někdy i jako součást kvalifikačni práce na fakultě.
} 
Pokud většina dotazovaných zaškrtne (nebo při dotazování označí odpověd') první dvě možnosti, svědčí to o tom, že instituce má problém v informování veřejnosti a o svém působení.

\section{B. stupeň přízně, který k ní respondenti pocituji (postoj ke škole)}

Těm, kteří vyjádřili pozitivní povědomí o instituci nebo ji dokonce dobře znají (odpovědi 3-5), můžeme položit následující dotaz, který vyjadřuje postoj respondenta vưči škole (jak príznivě je $k$ instituci nakloněn).

Příklad otázky: Vyjádřete prosím pomocí následujících možností váš postoj, vaši náklonnost ke škole xy:

1. velmi nepř́iznivý,

2. spíše nepřiznivý,

3. je mi to jedno (neutrální),

4. spiše příznivý,

5. velmi př́znivý.

\section{Vyhodnocení:}

Zvažujeme dva údaje. Můžeme je hodnotit jako dvě dimenze:

\section{A. instituce je u cílové skupiny známá - neznámá (osa $\mathrm{x}$ )}

B. respondenti, kteří instituci znají, vyjádřili svůj postoj k ní jako příznivý - nepříznivý (osa y)

Výsledky můžeme vynést do jednoduchého grafu, ze kterého je zřejmá image školy. Pokud bude šetření prováděno např. pro základní školu ve středně velkém městě nebo pro střední školu v regionu, můžeme zjistit postavení image sledované školy ve srovnání s ostatními školami, pokud se budeme stejně dotazovat i na dalši subjekty. Z uvedeného naopak vyplývá, že tento způsob měření image nemá zejména v prvním údaji smysl pro školu, která je jediná v malém městě apod.

Postavení image školy (př́klad)

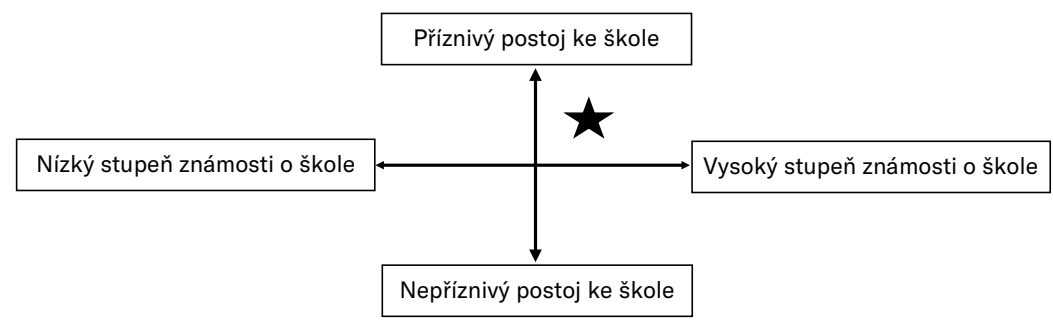

Obrázek 16: Schéma zobrazení image školy, stupeň známosti a postoj ke škole 
Vyhodnocení výsledků (stručně)

Výsledky dotazování v jednotlivých otázkách zpracováváme tak, že četností odpovědí ve škále vynásobíme přiděleným bodem položce (např. 3 pro: znám ji), sečteme hodnotu za všechny vynásobené položky a vydělíme celkovým $n=$ počtem dotázaných. Výsledek zaneseme na ocejchovanou osu, kde střed má při pětistupňové škále hodnotu 3.

Jestliže většina dotazovaných použije pro vyjádření známosti (otázka A) první dvě položky škály, nebo potom u vyjádření postoje ke škole první tři možnosti u otázky B, pak je zřejmé, že škola má negativní image.

\section{(2) Nevýhody}

Pro podobné šetření je nutné realizovat dotazování v terénu. U středních a vyšších škol je na to možné použít vyškolené studenty u základních škol je to možné jen u nejvyššího ročníku s dobrým vedením například třídního učitele.

Vážnou otázkou zůstává výběr vzorku respondentů. Nejsnazší je např. provést pouze anketu v obci prí jejím rozdělení dle čtvrtí a respondentů podle pohlaví a věku. Reprezentativnost souboru bude problematická, ale domníváme se, že to nic nemění na užitečnosti podobného průzkumu a jeho využitelnosti $\mathrm{k}$ např. v diskusi ve sboru školy o její image.

\section{Sémantický diferenciál}

Tato metoda je vhodná pro podrobnější analýzu obsahu image škol, výsledky jsou vyjadřovány přehledně v grafické formě a máme s ní dobré praktické zkušenosti. Následuje její stručný popis pro management škol (podle materiálu Eger a Egerová, 2001):

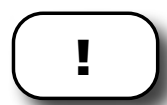

Definice

Osvědčenou a často používanou metodou měření image je sémantický diferenciál (polaritní profil). Ve vztahu ke zjištovaným komponentům image je sestavena řada protikladných pojmových dvojic. Výběr bipolárních adjektiv je dán cílem šetření. Protikladné dvojice pojmů jsou uspořádány na sedmistupňové nebo pětistupňové škále (Přibová, 1996). ${ }^{89}$

${ }^{89}$ Podrobněji viz i Klement, Chráska \& Chrásková (2015). 


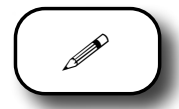

Metoda sémantického diferenciálu byla původně vyvinuta v psychooligvistickém výzkum v USA Osgoodem a kol. (1957). My ji ovšem použíáme tak, jak je využita v marketingu pro účel výzkumu trhu. $V$ kurzech školského managementu v Anglii jsme se setkali s tím, že s dotazníkem se pracuje spíše jako s baterii škál a přizpůsobuje se v položkách zadání vedením školy. Dotazník, splňující parametry sémantického diferenciálu (viz stručný popis níže), který byl použit ve stovkách škol, je v príloze $F$.

Výběr vlastností k (obvykle 15) se provádí podle účelu, ke kterému je jev zkoumán.

V klasickém sémantickém diferenciálu jsou proporčně uplatněny 3 hlavní skupiny faktorů: ${ }^{90}$

- faktory hodnotící (dobrý - špatný, kvalitní - nekvalitní, hezký - škaredý, nápadný - nenápadný, pohodlný - nepohodlný),

- faktory potenční (prostorný - těsný, bezpečný - málo bezpečný, silný - slabý, ovladatelný - neovladatelný, velký - malý)

- faktory aktivity (rychlý - pomalý, ekonomický - neekonomický, výkonný - nevýkonný, vyvolávající závist - vyvolávající pohrdání, pohyblivý - nepohyblivý).

$* * *$

Pro sestavení a vyhodnocení konkrétního sémantického diferenciálu je potřebné:

1. vytvořit skupinu relevantních dimenzí

Výzkumem nebo expertně je potřebné určit, které dimenze lidé použivají k popisu sledovaného objektu. Získáme je rozborem otázek, které se týkají školy, které např. hledáme při snaze o posouzení odlišností mezi školami atd.

\section{2. redukce získaných relevantních dimenzí}

Vytváríme vlastní dotazník, kde na základě našich zkušeností z praxe doporučujeme uspořádat pojmy tak, že např. na levé straně jsou všechny pozitivní, na pravé straně pak pojmy negativní. ${ }^{11}$ Při výběru přihlédneme $\mathrm{k}$ výše uvedeným informacím o skupinách faktorů. Přikláníme se

\footnotetext{
${ }^{90}$ Podrobněji viz Eger, Egerová \& Pisoňová (2018).

${ }^{91}$ Původně se doporučovalo orientaci dimenzí střidat. V současné době respondenti spiše scanuji text, než podrobně čtou, a proto je vhodné „uživatele nenutit přemýšlet“. Jinak v rychlosti odpoví chybně.
} 
ovšem k tvrzení Světlíka (1996), že při této volbě pro naše účely někdy méně může znamenat více (volte $6,9,12$, maximálně 15 dimenzí).

\section{3. zadání otázek skupině respondentů}

Pro náš účel budou nejdůležitějšími skupinami: studenti (žáci), rodiče, učitelé školy. Mezi dalši důležité skupiny můžeme zařadit: představitelé obce (zastupitelé i úředníci), ČŠI, MŠMT, potenciální studenti, ostatní veřejnost aj. Nicméně dotazování těch ostatních je $v$ praxi problematické.

\section{4. vyhodnocení výsledků}

Odpovědi se $v$ jednotlivých položkách u jednotlivých skupin respondentů zprůměruji a graficky zobrazí. Výsledná vertikální linie představuje sumarizovaný pohled na image instituce. Jednotlivé skupiny respondentů vyhodnocujeme zvlášt a můžeme tak zobrazit i rozdíl $v$ hodnocení jednotlivých skupin.

\section{5. prověření variací image}

Protože profil každé image je výsledkem zprůměrování hodnocení řady respondentů, doporučuje Štefko (1999) použivat statistické odchylky, na jejichž základě můžeme stanovit, zda je image specifická (s malou odchylkou) nebo rozptýlená. Instituce může, ale nemusí chtít specifickou image. Někdy je potřebné také analyzovat, zda rozptýlená image je skutečně výsledkem různých hodnotících podskupin, přičemž každá podskupina má o instituci vytvořenou jinou, ale vysoce specifickou image. Image u velkých škol může být také spojena s image jednotlivých studijních programů.

\section{Indikátory image školy}

Pro sestavení vlastního dotazníku musíme vyhledat tzv. indikátory image, kterými lidé obvykle popisuji sledovaný objekt. Pro náš účel, tedy zjištování image naší školy, je můžeme stanovit na základě odpovědí na základní otázky, které si vytváŕíme, když uvažujeme o hodnocení školy.

\section{$(-)$}

Námět pro praxi

Co vás napadne, když uvažujete o hodnocení školy? Co nejlépe charakterizuje školu?

- Jaký první dojem poskytne škola svým návštěvníkům?

- Jaký dojem vyvolává budova?

- Jak vypadá třída, kde se uči mé dítě?

- Jak kvalitní je třídní učitel-ka? 
- Jaké informace a jak kvalitně je škola o sobě poskytuje?

- Bude se žák ve škole cítit bezpečně?

- Jakým způsobem mě škola informuje o mých dětech?

Každé vedení školy si může vytvořit (dotvořit) svůj vlastní seznam indikátorů image školy tak, aby zobrazené výsledky dávaly odpověd' na položky, které vedení školy může i specificky zajímat. ${ }^{92}$

Je ovšem vhodné využivat již připravených seznamů možných položek - komponent (viz např. Světlík (1996) nebo náš dotazník (Eger \& Egerová, 2001) $v$ jeho poslední úpravě v príloze $F$.

Odborníci jistě mohou oponovat, že vytvoření vhodného nástroje není jednoduchou záležitostí, ale na druhou stranu právě pro zvýšení zapojení především pedagogického sboru do procesu autoevaluace a řízení kvality ve škole doporučuji tento postup např. Evans (1995), Elsner (1999), Fidler (2002) a potvrzuje to i naše zkušenost z praxe $v$ ČR.

Obrázek níže ukazuje příklad zobrazení sémantického diferenciálu (jen 6 položek).

$\begin{aligned} & \text { szkola je velká } \\ & \text { je dobré }\end{aligned}$
$\begin{aligned} & \text { management školy } \\ & \text { je výkonný }\end{aligned}$
$\begin{aligned} & \text { kvalitní vzdělávací program šmoly } \\ & \text { inovace vzdělávacího } \\ & \text { programu je rychlá }\end{aligned}$
$\begin{aligned} & \text { široká nabídka } \\ & \text { mimoškolních aktivit }\end{aligned}$
$\begin{aligned} & \text { Legenda: } \mathrm{R}=\text { rodiče, } \mathrm{Z}=\text { žáci, } \mathrm{U}=\text { učitelé } \\ & \text { škola je malá }\end{aligned}$

Obrázek 17: Příklad zobrazení výstupu sémantického diferenciálu

\footnotetext{
${ }^{92}$ Napríklad v jednom šetřeni vedeni velmi zajímalo, jak je hodnoceno stravování. Jindy jsou to doplňkové služby či určité aktivity...
} 


\subsection{Vyhodnocení výsledků a příprava plánu pro image školy}

Měřním image jsme nyní zjistili, jaké jsou pohledy jednotlivých skupin respondentů na silné a slabé stránky školy, které jsme zobrazili např. v relevantních dimenzích v sémantickém diferenciálu grafickým vyjádřením. Pravděpodobně také zjistíme, že jednotlivé skupiny (včetně učitelů) mají odlišné pohledy, které je potřebné znát, jestliže máme projektovat image instituce.

\section{! Kličový bod}

Na základě analýzy měření image u relevantní veřejnosti můžeme dojit obvykle k následujícím čtyřem základním závěrům (Eger \& Egerová, 2001), ze kterých vyplývají následné strategie pro plánování komunikace a dalších aktivit pro zvýšení či udržení image instituce:

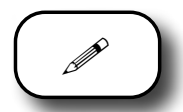

- výsledek: málo lidí zná školu, ale ti, co ji znají, o ní mají dobré povědomí. Strategie: velké zvýšení komunikace a informovanosti o škole v regionu.

- výsledek: hodně lidí zná a pozitivně hodnotí školu.

Strategie: udržování dobré image školy a udržování širokého pozitivního povědomí o škole.

- výsledek: málo osob zná školu, ale ti, kteří ji znají, ji hodnotí negativně. Strategie: je potřebné diagnostikovat přičiny negativního hodnocení a připravit plán, který bude minimalizovat negativní faktory a vytvářet pozitivní pohled na školu v regionu.

- výsledek: hodně lidí zná školu, ale nejeví se jim pozitivně.

Strategie: je potřebné rychle nalézt príčiny negativního hodnocení a odstranit to, co je způsobuje, dále je nutné připravit plán pro vytvoření pozitivní image o škole v regionu a postupně jej realizovat.

\section{(;)}

Při sestavování vlastniho reálného plánu postupu je potřebné začít definováním žádoucí image své školy. 


\section{! Definujte s kolegy žádoucí image své školy!}

Jestliže jste již realizovali měření image vaší školy, můžete s výsledky seznámit učitele. Pokud ne, tak je nyní vhodný okamžik pro realizaci průzkumu i se zapojením některých aktivních učitelů do projektu. Na základě vytvořené definice a získaných závěrů z průzkumu image školy můžete již tvořit konkrétní plán pro vaši školu $v$ této oblasti. Rozdíly mezi prezentovanou image školy z průzkumu a požadovanou z definování managementem a pedagogickým sborem jsou kličcovou oblastí pro príjetí řešeni ve strategickém plánu školy.

Pro vlastní plán doporučujeme vzít v úvahu nejen výsledek měření image, ale i výsledky odborného hodnocení školy. Pro ZŠ a SŠ to je např. hodnocení ČŠl, využiváme výsledky národních a mezinárodních srovnávacích testů (SCIO, TIMSS, výstupů přijímacího řizení na SŠ aj.). Samozřejmě využijeme i výstupy ze SWOT analýzy školy.

\section{Upozornění}

Odlišnosti mezi profesionálním hodnocením školy a výsledkem měření image zejména u relevantní veřejnosti a u žáků / studentů je nutné brát v úvahu při vytváření strategie dalšího postupu (viz úvodní teorie k image organizace).

\section{(-) Námět pro praxi}

Při plánování je samozřejmě opět vhodné zapojit ostatní pracovníky školy a někdy i žáky či studenty!

Plán musí zahrnovat nejen úkoly, ale i etapy s časovým plněním, personální, materiální a finanční zabezpečení aktivit a samož̌ejmě také způsob kontroly.

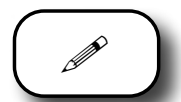

Kličový bod

Ve strategiích zaměřených na image se objevují následující kroky (dle Elsner, 1999):

- diagnóza negativních príčin,

- jejich minimalizování, 
- vytváření pozitivní prestiže školy v regionu,

- udržování pozitivní image,

- neustálé informování komunity o činnosti školy. ${ }^{93}$

Zvažte následující poznámky:

- Plánovaná image musí být realistická a spojená s reálnou činností školy. Největší chybou v komunikaci školy je potom podle Evanse (1995), když škola neví, co chce komunita!

- Postoje nadřazenosti nebo naopak zahleděnosti školy do sebe jsou také chybami, které se škole ve styku s veřejností, zastupitelstvem apod. nemusí vyplatit.

- Pozor na nechtěnou publicitu, může mít kladný ale i výrazně záporný výsledek. ${ }^{94}$

- Také výběr školy je spojen s tím, jaké informace o kvalitě školy rodiny mají, respektive, jak vnímají image školy (Lubienski, 2007).

Image školy je ovlivnitelná jak objektivními charakteristikami školy (budova a její okolí, vybavení atd.), z nichž některé Ize měnit někdy jen obtížně nebo jen s velkými náklady, tak subjektivními charakteristikami vnímání instituce jednotlivými skupinami respondentů.

Současná image instituce (a to zejména v oblasti vzdělávání) je obyčejně založena na její předešlé pověsti a vykazuje relativní stabilitu. Proto v závěru této kapitoly opět zdůrazňujeme, že je nutné počitat $s$ tím, že $u$ řady faktorů dosáhneme změny jen dlouhodobou a trpělivou prací a musíme $v$ praxi počítat i s tím, že zejména někteři lidé (naši respondenti, kteři mohou být také zákazníci nebo pracovníci instituce) mohou mít odlišné názory na image naší školy, které mohou být dokonce i odtržené od současné reality.

${ }^{93}$ Marketingové komunikaci se věnujeme v dalšich kapitolách této publikace.

${ }^{94} \mathrm{~K}$ tomu dále viz sociální média a tzv. WOM. 


\section{? Kontrolní otázky a úkoly:}

- Proč by mělo vedení školy věnovat pozornost image školy?

- Na jakém základě si veřejnost vytváŕí obraz o škole?

- Jak můžeme měrit image školy?

- Kde (jak) získáme dimenze image školy?

- Můžou mít různé vzdělávací programy střední školy odlišnou image?

- Co je vhodné brát v úvahu při plánování komunikace image školy?

[DD Literatura:

Eger, L., \& Egerová, D. (2001). Image školy. Liberec: TU Liberec.

Světlík, J. (1996). Marketing školy. Zlín: EKKA.

Vysekalová, J., Mikeš, J., \& Binar, J. (2020). Image a firemní identita. Praha: Grada. 


\section{MARKETINGOVÁ KOMUNIKACE A KOMUNIKAČNÍ KAMPAŇ}

\section{米}

\section{Cíle:}

- Pochopit rozdíl mezi ATL a BTL a význam integrace médií $v$ komunikaci.

- Umět rozdělit používaná média na placená, vlastněná a zasloužená.

- Získat základní doporučení pro plánování komunikační kampaně školy.

- Pochopit, jak je vhodné formulovat komunikační sdělení pro cílové skupiny.

komunikační kampaň, média, $5 \mathrm{M}$, sdělení, apely, positioning

Čas potřebný ke studiu základního textu kapitoly je cca 15 minut + možnost rozšǐrení o studium externích zdrojů $z$ internetu.

\section{Úvod}

Marketéři, kteři chtěji dnes realizovat efektivně integrovanou marketingovou komunikaci, musí používat kombinaci všech tři forem médií, viz obrázek 18. Je potřebné si nejdřive určit, jak hodnotná jsou jednotlivá média a jejich nástroje pro školu z pohledu, že nejdůležitější je pro nás, aby média a jejich nástroje byly efektivní při oslovování našich cílových skupin. Samožrejmě je potom důležitý cíl kampaně, který by měl vycházet z naši strategie. 


\subsection{Realizace reklamní (komunikačni) kampaně}

Podivejme se nejdřive stručně, jak to funguje v podnikové oblasti. Většina středních a větších organizací a podniků při realizaci marketingových aktivit využivá služeb reklamních agentur a mediálních agentur. Řada agentur se dnes snaží společnostem nabídnout komplexní řešení a celkově zvyšovat účinnost marketingové komunikace. I z těchto důvodů se také nazývají různě a v jejich názvu se objevuje i komunikační, marketingová, mediální atd. ${ }^{95}$

Z hlediska analýzy trhu, ale i vyhodnocení reklamy vstupuji do hry i agentury zaměřené na výzkum trhu nebo je tato činnost součástí nabídky výše uvedených agentur, protože se snaži komplexně obsloužit své zákazníky.

V praxi v organizacích a podnicích jsou marketingová komunikace a reklama jako jeji součást poměrně odlišně řízeny v malých a středně velkých organizacích a ve velkých korporátních firmách. $V$ malých a středních podnicích za reklamu odpovídá obvykle někdo, kdo patři pod obchodní nebo marketingové oddělení a praktickou realizaci marketingových cilů v oblasti reklamy často reši ve spolupráci s reklamní agenturou. Ve větších organizacích a firmách je obvykle manažer marketingu, který za integrovanou marketingovou komunikaci odpovídá přimo top managementu. Jím řizené specializované oddělení pro marketing má vlastní rozpočet a rozpracovává marketingové cíle z firemní strategie do dílčích kampaní, které dnes obvykle koordinuje právě dle zaměření a stanoveného cíle. Reklamní kampaně v různých formách jsou potom součástí (nebo by měly být součástí) celkového konceptu marketingu.

\section{? Kdo řídí a realizuje komunikační kampaně ve školách?}

Odpověd' bude jednoduchá z hlediska odpovědnosti. Odpovědný je samozřejmě ředitel / ředitelka školy. Podobně, jako viz výše, u velkých škol do této aktivity zapojuje členy vedení školy nebo si i vytváři malý tým, který se problematikou plánování, realizování a vyhodnocování komunikačních aktivit přímo zabývá. Někde tomu napomáhá i zaměření škol (např. střední škola s ekonomickým zaměřením), někde je to opravdu jen na řediteli (malá ZŠ či MŠ). I proto jsme do předložené publikace vložili tuto kapitolu, která čtenárưm přinese základní poznatky z plánování komunikační kampaně.

\footnotetext{
${ }^{95} \mathrm{~S}$ rozvojem internetu se objevily i specializované digitálni agentury a naopak velké „klasické“ agentury maji nyni odděleni pro digitální reklamu apod.
} 


\subsection{Média a jejich využití v reklamní kampani}

Než začneme plánovat komunikační aktivity, je vhodné si stručně popsat a také rozdělit základní média, která máme dnes k dispozici.

Jedno z možných členění je na k tzv. nadlinková média a komunikační aktivity a prostředky ( $A T L=$ above the line) a podlinková ( $B T L=$ below the line).

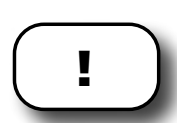

Nadlinkové marketingové komunikační aktivity (ATL) patří k neosobní části marketingových komunikací. Tato skupina aktivit je realizována především prostřednictvím masmédií, tj. televize, rozhlasu, tisku a billboardů (viz např. Postler, \& Bárta, 2020). ATL marketingové komunikační aktivity byly dřive zásadní (původně jediné) pro budování trhu, pro prezentování produktů spotřebitelům a pro jejich přesvědčování ke koupi atd.

Pro komunikátora v masové komunikaci jsou přijemci sdělení anonymní (jsou masou = masová komunikace). Př́jemce je zastoupen určitou částí veřejností a v praxi napřiklad mluvíme o televizních divácích, rozhlasových posluchačích, čtenárích novin a časopisů, uživatelích portálu či divácích $v$ kinech. Předpokladem masové komunikace je tedy přítomnost masového publika. Komunikátor použivá prostředníka (médium) pro přenos sdělení. Tato sdělení jsou veřejná a obvykle dochází i $k$ jejich určité periodicitě (zprávy v televizi, denní tisk, měsičník, aktualizace novinek na portále...). Od neosobního kontaktu mezi komunikátorem a přijemci sdělení se odvijí spíše náhodná a neplnohodnotná zpětná vazba, i když mnohá média vám poskytnou statistiky diváků, posluchačů, přijemců... Pro marketingovou komunikaci je nutné podtrhnout i fakt, že komunikátor vysílá jednosměrný tok sdělení, který může být na straně přijemců kdykoliv přerušen. ${ }^{96}$

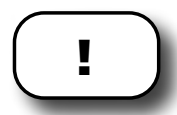

Podlinkové marketingové komunikační aktivity $(B T L)^{97}$ jsou aktivity, které nevyuživají jen mediální formy reklamního poselství, ale v převážné míre se zde uplatňují osobní formy komunikace nebo formy komunikace prímo adresně a osobně působící na konečného spotřebitele. Bárta a kol. (2009, s. 138) sem zejména řadí podporu prodeje, podporu distribuce a sampling.

\footnotetext{
${ }^{96}$ ICT a zejména sociální média tuto jednosměrnost podstatně změnily.

${ }^{97}$ Také se někdy uvádi, že je to reklama bez nutnosti platit za jeji zprostředkování masmédiím.
} 
My sem doplňujeme, že dnes jsou BTL aktivity často spojeny s novými médii a technologiemi, což odpovídá i osobním formám komunikace např́klad na sociálních sítích či u mobile marketingu. ${ }^{98}$

Nicméně hlavním poznatkem je, že dnes při realizaci účinné marketingové komunikace v naprosté většině jdeme „skrz“ linky = TTL (through to line). ${ }^{99}$ Trendem i ve firemní prostředí je přesun od ATL k BTL, který je možné zachytit i v poměru vynaložených finančních prostředků věnovaných na tyto aktivity. Přitom je zajímavé, že např́iklad Public Relations podle některých autorů patři prímo na linku (Bárta a kol., 2009, s. 141) a tvoři tedy rozhraní mezi ATL a BTL. Z uvedeného také plyne, že čím menší rozpočet škola má, tím spíše, i z objektivních důvodů, se musí zaměřit na cílené a pokud možno i personalizované komunikačni aktivity.

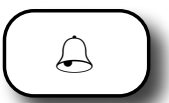

Zvažte:

Jaké jsou dnes trendy v uživání médií? ${ }^{100}$ Dochází k poklesu vlivu tradičních médií u určitých cílových skupin: televize, rádio, tisk, a naopak k růstu vlivu nových médií (zejména u generace $Z, Y$ a částečně i $X$ ), tj. internet $s$ www stránkami, sociálními médii a komunikací s využitím mobilních telefonů.

\section{Média dnes významně ovlivňují kvalitu života lidí.}

\section{?}

\section{Jaká je mediální gramotnost představitelů vaší cílové skupiny?}

Při přípravě komunikační kampaně je potom v kontextu integrované marketingové komunikace potřebné zvolit odpovídající média. Vysekalová a Mikeš (2018, s. 40) k tomu uváději: „Média samožrejmě vybíráme tak, aby optimálním způsobem oslovila naše cílové skupiny, aby jednak přenášela informace, jednak dokázala vyvolat emoce." Musíme brát v úvahu zejména to, zda pro uvažovanou cílovou skupinu je médium vhodné (zda jej konzumuje), a tedy je možné sdělením v tomto médiu cílovou skupinu efektivně oslovit.

\footnotetext{
${ }^{98}$ At se nám to líbí nebo ne, média a zejména digitální technologie hraji v životě dnešních dětí a dospívajících kličovou roli, podrobně výzkum Nielsen Admosphere (Friedlaenderová, 2019).

${ }^{99}$ Kozel a kol. (2011, s. 266) rozděluje média na vysílací, tištěná, internet a ostatní.

${ }^{100}$ Pospišil a Závodná (2009) upozorňuji na kulturní změny a použivání médií, a také na spotřební orientaci lidi.
} 
Proto je vhodné se podívat i na nové členění médií, které také s odkazem na zahraniční zdroje a firmu Nokia, prezentuje Světlík (2016), podobně i Belch a Belch (2021). Obrázek 18 charakterizuje členění médií na placená, vlastněná a zasloužená $z$ pohledu obsahu, benefitu, rizik a jejich zacílení. Mezi jednotlivými typy médií dochází k dynamické integraci, kdy například placená média usměrňuji pohyb do vlastních médií a současně obsah vlastních médii může být vytvářen v návaznosti na obsahy médií zasloužených. Níže uvedené schéma je námi upravenou verzí.

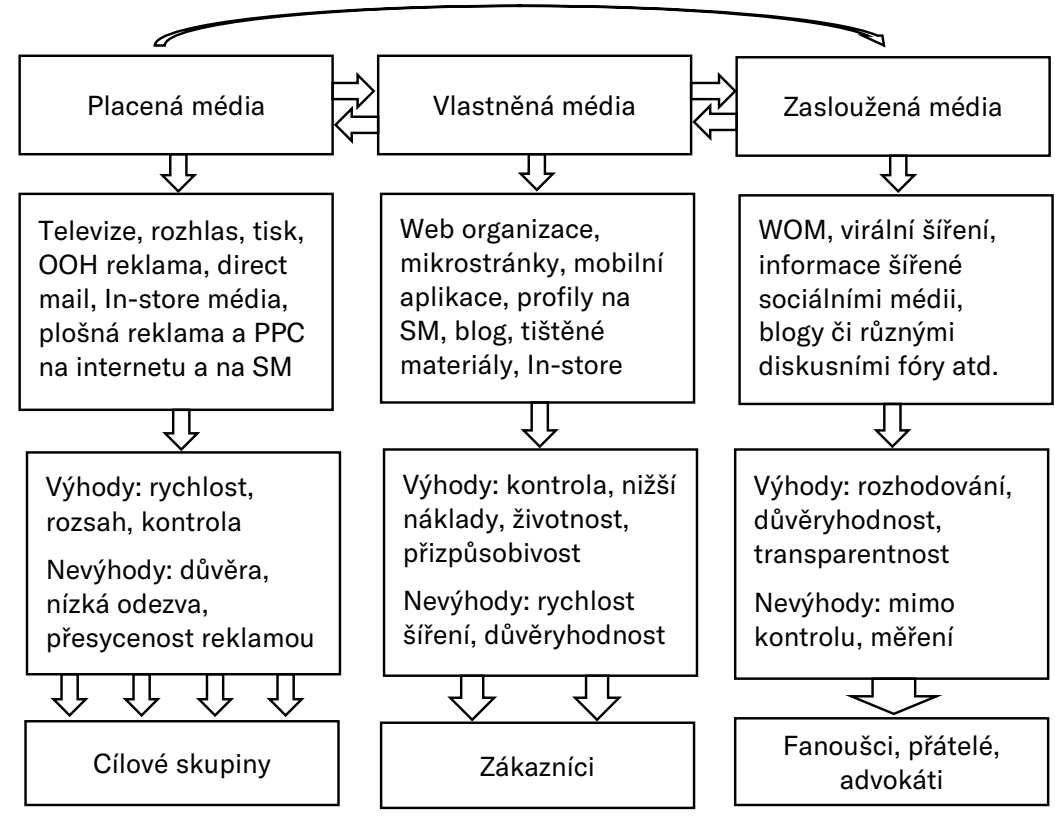

Obrázek 18: Placená, vlastněná a zasloužená média, upraveno dle Světlík (2016)

Pod placenými médii zde najdeme zejména ta, kde můžeme poměrně rychle, $s$ velkým dosahem a určitou kontrolou realizovat placenou neosobní reklamu. Školy zejména televizi využivají omezeně u celostátních kanálů pro velkou finanční náročnost. In-store (napřiklad reklama v nákupních centrech) též využívají minimálně. $\mathbf{V}$ posledních letech jsme ovšem svědky toho, jak i intenzivně před přijímacím řízením je využívaná reklama v rádiu, tisku, ale i tzv. venkovní $(\mathbf{O O H})$ s použitím billboardů a reklamních plachet, laviček, plakátů atd. Podobně je využívaná placená reklama na internetu v mnoha 
formách. Můžeme zasáhnout širokou veřejnost, ale negativně zde působí i přesycenost reklamou. ${ }^{101}$

Vlastněná média jsou doménou marketingové komunikace škol. $\mathrm{Od}$ vlastních www stránek (a komponent jako jsou školní časopis či blog atd.), přes profily škol na sociálních sitích, až po formy $\mathrm{OOH}$ na budovách škol a dalších zařízeních (hřiště). Mezi tradiční patři využivání tištěných materiálů a mezi nové využivání mobilních aplikací. In-store zde znamená například vlastní nástěnky či vitríny ve škole. Lepší cílení na relevantní cílové skupiny je zde výhodou, a to i prí nižších nákladech proti placeným médiím a velmi dobré kontrole sdělení.

Zasloužená média podporují WOM a je potřebné připomenout, že jsou oblíbená u současných studentů a rodičů generace Y. Komunikace zde je výsledkem chování veřejnosti ke škole, respektive interakce s ní. Úspěch je postaven na naslouchání této komunikaci a na vhodném reagování nejenom na pozitivní, ale zejména na negativní sdělení. Tuto část komunikace nemáme nikdy plně pod kontrolou a významnou roli zde hrají důvěra uživatelů ve školu a transparentnost naší komunikace.

Média a jejich využití pro komunikaci školy s veřejností

Udělejte si jednoduchý audit médii ve vztahu k vašim hlavním cílovým skupinám. Sestavte si matici, kde $v$ horní části budete mít přehledně média (komunikační kanály) a z leva ve sloupci budete mít seřazené cílové skupiny (segmenty). Vyhodnotte pomocí znamének + a - vliv kanálu na cílovou skupinu. Sílu vyjadřujte v rozsahu od 3 plus do 3 minus. Ukázka:

Tabulka 9: Komunikační kanály a jejich vliv na různé cílové skupiny

\begin{tabular}{|l|c|c|c|c|}
\hline \multirow{2}{*}{ Segment } & \multicolumn{4}{|c|}{ Média (komunikačni kanály) } \\
\cline { 2 - 5 } & Tisk - noviny & Rozhlas & Www školy & Facebook \\
\hline Mladší učitelé & + & + & +++ & +++ \\
\hline Starši učitelé & ++ & ++ & ++ & + \\
\hline Studenti & -- & - & +++ & +++ \\
\hline Rodiče & + & ++ & +++ & ++ \\
\hline
\end{tabular}
${ }^{101}$ Již řadu let probihá výzkum Češi a reklama, podivejte se na výstupy studií na stránkách České marketingové
společnosti. 
Doplňte si dalši cílové skupiny (více je specifikujte) a doplňte i média, jež využiváte (i zde můžete doplnit až na prostředky). Pro školu typické: informační systém ve škole (nástěnky), školní informační systém elektronický, billboardy školy, letáky a brožurky...

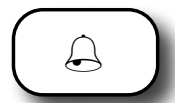

Lockhart (2016b, s. 19) uvádí: „Protože lidé, kteři nemaji své děti přímo ve škole, obecně mají malý nebo žádný kontakt se školou, utvářejí si svůj názor na vzdělávání a školu prostřednictvím sekundárních zdrojů, kterými jsou nejčastěji média."

\subsection{Plánování komunikační (reklamni) kampaně}

Vzhledem $\mathrm{k}$ tomu, že řada subjektů regionálního školství již zcela běžně skutečně realizuje i pravidelně reklamní kampaně a dílči komunikační aktivity, uvedeme i v této publikaci základní informace, jež vám pomohou v praktické realizaci.

\section{$\square$}

„Komunikační mix je vytvářen tak, aby splnil dané marketingové a komunikační cíle.“ (Vysekalová a Mikeš, 2018, s. 20)

\section{!}

Reklamu, respektive reklamní kampaň můžeme rozdělit také na základě prvotního cíle jejího sdělení. Niže uvádíme v aplikaci pro školy:

- informační reklama (cílem je oznámit zákazníkům-klientům, že daný vzdělávací program a dalši služby školy jsou na trhu k dispozici nebo vytvářet povědomí o značce),

- přesvědčovací reklama (úkolem je rozvinout či podpořit poptávku po vzdělávacím produktu),

- a připomínková reklama (účelem je udržovat pozici vzdělávací, služby, školy a její značky a stimulovat cilové skupiny k „opakovanému nákupu“). 
Někteři autoři v této souvislosti uváději ještě čtvrté zaměření reklamy, a sice reklamu posilující. Ta má přesvědčit současné zákazníky-klienty o tom, že správně volili, když zvolili vaši školu a její vzdělávací program. V oblasti regionálního školství doporučujeme pro tento účel spíše využít osobní komunikaci (osobní prodej) ve škole se studenty / žáky a jejich rodiči. Dnes také i elektronickou komunikaci s využitím sociálních médií a profilů školy na těchto médiích.

\section{Základní doporučení pro plánování komunikační (reklamní) kampaně}

I když pro regionální školství nebude reklama jako placená neosobní forma komunikace ž̌ejmě na prvním místě v celém komunikačním mixu, můžeme pro plánování komunikační kampaně vhodně využít tzv. $\mathbf{5} \mathbf{M}$ podle Kotlera a Kellera (2007, s. 606). Prohlédněte si výčet níže, včetně návodných otázek:

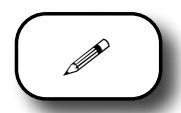

- Poslání (mission) = Jaké jsou cíle komunikační kampaně (reklamy)?

- $\quad$ Peníze (money) = Kolik prostředků může být vynaloženo?

- Sdělení (message) = Jaké sdělení má být vysláno cílovým skupinám?

- Média (media) = Jaká média použijeme?

- Měření (measurement) = Jak budeme vyhodnocovat výsledky komunikační kampaně?

\section{Stanovení cílů komunikační kampaně}

Reklamním cílem je konkrétní stanovený komunikační úkol. ${ }^{102}$ Měl by být stanoven měřitelně a v zadání budeme uvádět cílové publikum, časové období a požadovaný výstup atd. viz dále brief. Cíle budou formulovány podle toho, jakou hlavní funkci má komunikační kampaň plnit (informovat, přesvědčovat, připomínat nebo posilovat) viz předchozí sdělení výše v textu.

Komunikační (reklamní) cíle ${ }^{103}$ by měly být stanovené na základě analýzy současné marketingové situace na trhu.

\section{Rozpočet}

Problematika výše výdajů na reklamu je tradičním tématem v podnikání v souvislosti s úvahami o efektivním vynakládání finančních prostředků a nejinak tomu musí být i pro segment vzdělávání.

\footnotetext{
${ }^{102}$ Provokativně k tomu uvedeme tvrzení Světlíka $(2011$, s. 6): „Hlavním cilem reklamy není nic jiného, než ovlivnit spotřebni chováni.“”

${ }^{103}$ | zde používejte formulováni cilů dle pravidla SMART.
} 
Uvedli jsme, že jeden z trendů v oblasti marketingu škol, je prezentování školy jako značky. Kotler a Keller (2007) již dřive upozornili na to, že výdaje na reklamu jsou ve skutečnosti často investicí do vytváření hodnoty značky. Nicméně, jak jsme již několikrát odkázali, pro subjekty regionálního školství platí v praxi řada specifik, jež jsou dané jejich postavením na „trhu“ ve svém regionu, ale i závaznými pravidly pro rozpočtování škol dle jejich právní formy. Na druhé straně je pravdou, že dnes stěži vybudujete značku a představite ji cílovým segmentům tak, aby na trhu zaujala, když nevynaložite (někdy i značné) prostředky ${ }^{104}$ na komunikaci včetně reklamy.

***

I pro školy můžeme při sestavování rozpočtu na komunikační kampaň brát v úvahu pět faktorů, které doporučuji Kotler a Keller (2007). Opět je dopIníme poznámkami pro školství.

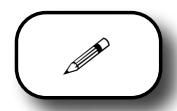

- Stadium životního cyklu produktu. I školy u vzdělávacího programu musí brát v úvahu, zda se teprve připravuje, uvádí na trh, nebo je to již známý program, či bude docházet $\mathrm{k}$ jeho ukončení a nahrazení jiným vzdělávacím programem. ${ }^{105}$

- Tržní podíl a spotřebitelskou základnu. Opět, viz specifika škol v regionu. Zvažte, že napřiklad některé studijni programy napřiklad SŠ mají široké uplatnění, jiné specifické mají omezenou základnu možných zájemců, ale i „odběratelů“.

- Konkurenci a změt sdělení na trhu (zejména na trhu s velkou konkurencí). Jednoznačně je patrné, že zejména v období, kdy vrcholí přihlašování studentů na SŠ nebo VŠ, je i v ČR mediální prostor plný komunikačních a reklamních sdělení.

- Potřebnou frekvenci reklamy. Ve školství je na jedné straně dané, kdy je „sezóna“ z hlediska získávání budoucích žáků a studentů, ale na straně druhé může v životě školy existovat celá řada dalších důvodů, proč je aktuálně potřebné vyvinout zvýšené úsilí v oblasti komunikace (př., výroči školy, velký úspěch školy nebo krizová komunikace, rozšiření nabídky, inovace vybavení, mezinárodní spolupráce...).

\footnotetext{
${ }_{104}$ Protože většina škol nebude komunikačni kampaň rešit jen placenou reklamou, zvažujme zde zdroje nejenom finanční, ale i lidské, časové, připadně materiální.

${ }^{105}$ Je to typičtějši pro SŠ, ale prošli jsme etapou kutikulárni reformy a dochází i k výrazným inovacim ŠVP, jež je potřebné komunikovat.
} 
- Možnost nahraditelnosti produktu jinou značkou (jiným produktem). Pokud se jedná o celou školu, tak si jistě můžeme vzpomenout na boj některých škol a vzdělávacích programů při optimalizace sítě $v$ regionech. Konkurence na úrovni ZŠ a zejména SŠ je ve velkých městech značná.

$* * *$

\section{Vytváření sdělení}

Prvním velkým problémem je přijit s námětem, který diferencuje od podobných (až stejných) sdělení, jež prezentuji konkurenční školy a vzdělávací programy na trhu (jejich značky). Také v oblasti vzdělávacích služeb dochází $k$ tomu, že $v$ současné době je nabídka řady škol v regionech i vysoce konkurenční, jejich kvalitní vzdělávací programy si jsou ve svých atributech velmi blízké a není jednoduché přijít $s$ nápadem, který ideálně komunikuje vaši školu a její značku.

I proto by součástí př́pravy komunikační, a $v$ tom reklamní, kampaně měl být výzkum trhu, aby se kvalifikovaně zjistilo, jak je možné co nejlépe oslovit cílové skupiny $v$ kontextu trhu, na který se chceme zaměřit. $V$ marketingu pro cílení na zákazníky a pro zvažování konkurence využíáme tzv. postioning.

\section{!}

Positioning (dle Belch \& Belch, 2021) je definován jako umění a věda o tom, jak umístit produkt či službu v jednom či více segmentech širokého trhu takovým způsobem, aby byl smysluplně odlišen od konkurence. Důležité je „umístěni“" naší vzdělávací služby v mysli našich současných i potenciálních zákazníků / klientů.

\section{?}

Jak je naše vzdělávací služba asi umístěna v mysli našich zákazníků?

Sdělení musí odpovídat vnímání členů cílových skupin a musí být pro ně srozumitelné, aby ho dokázali interpretovat (Vysekalová \& Mikeš, 2018). ${ }^{106}$ Dnes se doporučuje vytvářet sdělení jako pozitivni přiběh o škole, její značce, o jejím vzdělávacím programu, jejích úspěšných absolventech i učitelích atd.

${ }^{106}$ Vysekalová a Mikeš (2018) také zdůrazňuji použití jazyka, který je srozumitelný cílové skupině. 


\section{!}

Zvažujeme positioning, kreativní strategii, obsah a formát, vizuální zpracování.

\section{$?$}

Čeho chceme dosáhnout? A jsme dostatečně odlišitelní od konkurence?

$\checkmark$ marketingu se kromě klasického modelu komunikačního procesu používá známý model AIDA, ale pro náš účel si stručně s odkazem na Kotlera a Kellera (2013, s. 521) popíšeme model hierarchie účinků, který předpokládá, že kupující je na produktu zainteresován a že i vnímá míru diferenciace. Dle našeho názoru to zejména odpovídá situaci, kdy rodina volí školu pro své děti. Zainteresovanost je u většiny rodin vysoká a vzhledem k hledání informací a zjištování referencí atd., ${ }^{107}$ je možné uvést, že v kontextu ČR již rodiny vědí, že existuje diferenciace mezi vzdělávacími programy a dalšími nabídkami škol v regionu.

Hierarchický model ukazuje také etapy, kterými zákazníci procházejí, když dochází k transformaci jejich vztahu a vnímání od značky (školy), o které nemaji povědomí, při jejím poznávání (i učení se o ní), až po její preferování, a nakonec až k propojení s ní, když se rozhodnou k „nákupu“. V modelu se uvažuji fáze, kdy přijemci sdělení nejdřive v kognitivní fázi poznávají značku (školu), potom přichází fáze afektivní (působení emocí), jež vede k vytváření preferencí a budování přesvědčení, a nakonec je fáze behaviorální, která konči akcí, tedy nákupem produktu (zapsání na školu, přihlášení žáka na kroužek....). ${ }^{108}$

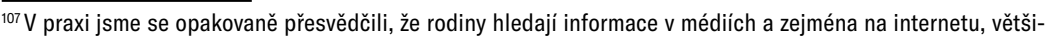
nou ale neumi pracovat s informacemi ze zpráv Čšl.

${ }^{108} \mathrm{~V}$ současné době se velmi zvažuje i tzv. sociálni rozhodovaci cesta zákazníka, která je významně ovlivněna soudobou interakci včetně využivání kanálů jako jsou sociální média (viz i Belch \& Belch, 2021).
} 
Tabulka 10: Model hierarchie účinků s aplikaci pro regionální školy v ČR

\begin{tabular}{|c|c|}
\hline Povědomí & $\begin{array}{l}\text { Pokud většina cílového publika nemá o škole, programu... } \\
\text { povědomí, musíme se jej snažit vytvořit (zvýšit). }\end{array}$ \\
\hline Znalost & $\begin{array}{l}\text { Cílové publikum má například povědomí o škole, ale neví } \\
\text { nic dalšího. Například neví, co specifického v našem ŠVP } \\
\text { nabízíme, jaké jsou naše další služby pro děti a rodiče atd. } \\
\text { Potřebujeme je dále informovat. }\end{array}$ \\
\hline Sympatie & $\begin{array}{l}\text { Cílové publikum školu a napřiklad její vzdělávaci program } \\
\text { znaji, ale je zde problém s negativnim pohledem... } \\
\text { potřebujeme získat sympatie a přesvědčit o kvalitě naši } \\
\text { školy a jejího vzdělávaciho programu. Zvažte, že dle Kotlera } \\
\text { a Kellera dobré Public Relations staví na: „dobrých skutcich } \\
\text { následovaných dobrým slovem“. }\end{array}$ \\
\hline Preference & $\begin{array}{l}\text { Cílové publikum vnímá školu sympaticky, ale při výběru školy } \\
\text { (nebo jejiho program) ji neuprednostñuje. Musime u cílové } \\
\text { skupiny vzbudit preference porovnáváním kvality, výkonu, } \\
\text { komunikováním hodnoty. (+zvažte: je zde vliv konkurence?) }\end{array}$ \\
\hline Přesvědčení & $\begin{array}{l}\text { Cílové publikum může program upřednostňovat, ale není } \\
\text { přesvědčeno o vstupu na tuto školu. Musíme například } \\
\text { přesvědčit zájemce o studium a povzbudit je v podáni přihlášky. }\end{array}$ \\
\hline Nákup & $\begin{array}{l}\text { Někteři členové cílového publika jsou přesvědčení a připraveni } \\
\text { „provést nákup“. Musíme přesvědčit váhající naší nabídkou... }\end{array}$ \\
\hline $\begin{array}{l}\text { Ponákupní } \\
\text { chování }^{*}\end{array}$ & $\begin{array}{l}\text { Cílová skupina již „nakoupila“. Zejména prostřednictvím Public } \\
\text { Relations je potřebné připomínat, že to byla vhodná volba a že } \\
\text { mohou být spokojeni. }\end{array}$ \\
\hline
\end{tabular}

*Tento účinek v původním modelu není, je to náš dodatek, který ale plyne z toho, že AIDA je dnes AIDAS (přidává se satisfaction) a pro marketing na internetu využiváme See-Think-Do-Care, kde je také zdůrazněn význam ponákupní fáze.

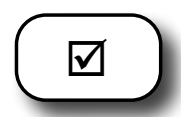
„Formulování komunikačního sdělení, které by dosáhlo zamýšlené odezvy, vyžaduje vyřešení tři otázek: co říci (strategie sdělení), jak to ríci (kreativní strategie) a kdo by to měl říci (zdroj sdělení).“

Kotler a Keller (2013, s. 524) 
Při vytváření strategie sdělení zvažujeme témata a myšlenky, které chceme sdělit a potom apely, které pro to využijeme a jež budou v souladu s vizí a misí naší školy a se zaměřením naší komunikace na relevantní cílové skupiny. Apely obvykle členíme na racionální, emocionální a morální. ${ }^{109}$ Bereme přitom v úvahu i zkušenost veřejnosti (cilových skupin) se školou a jejím vzdělávacím programem.

\section{Námět pro vytváření sdělení, Logos, Éthos, Pathos}

Logos, Éthos a Pathos jsou techniky přesvědčování, které tvoři rétorický trojúhelník. ${ }^{110}$ Zvažte, že působivá reč, prodejní argumentace nebo reklama v ideálním případě využívaji prvky všech tří strategií.

\section{Každá kategorie vyvolává jinou přitažlivost mezi řečníkem a publikem.}

- Étos vyzývá k etice mluvčího nebo k jeho hodnotám (též kredit mluvčího).

- Pathos vyvolává v publiku emoce.

- Logos vnáší do hry logiku pomocí důkazů a faktů.

\section{Logos}

- Je sdělení jasné a konkrétní?

- Je sdělení podloženo pádnými důvody a důvěryhodnými důkazy?

- Je argument logický a uspořádaný v dobře odůvodněném pořadí?

\section{Ethos}

- Jaká je kvalifikace toho, kdo sděluje?

- Jak se sdělující zapojuje či vztahuje k tématu?

- Použivá relevantních a důvěryhodné zdroje?

- Odpovídá tón publiku / účelu?

- Je dikce (volba slova) vhodná pro cílové publikum / účel?

- Je sdělení předkládáno propracovaným a profesionálním způsobem?

\section{Pathos ${ }^{111}$}

- Použivají se živé přiklady, detaily a obrázky (videa), aby zaujaly emoce a představivost posluchače?

- Apelujete na hodnoty a přesvědčení cílové skupiny na příkladech, které je zajímaji?

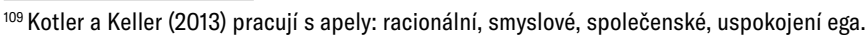

${ }^{110} \mathrm{Za}$ autora je uváděn Aristoteles.

${ }^{111}$ Šest základních emoci: hněv, znechucení, strach, štěstí, smutek, překvapení.
} 


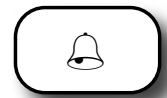

Uvedený seznam otázek si vždy můžete projit, když si budete chystat projev k publiku.

$* * *$

\section{Kreativní strategie sdělení}

Kreativní strategie je vlastně způsobem, jakým převádíme navržené sdělení $s$ jeho apely do konkrétní podoby komunikace. Tzv. informační zaměření apelů se zaměřuje na vlastnosti napríklad vzdělávacího programu a jeho výhody. Tzv. transformační apely zdůrazňuji prínosy pro cílovou skupinu plynoucí z image a značky. Zvažte opět pohled cílové skupiny, co a jak je oslovuje?

\section{Zdroj sdělení}

\section{U zdroje sdělení zvažujeme jeho odbornost, spolehlivost a oblíbenost.}

\section{?}

- Zvažte napřiklad, jak oblíbené, ale také jak důvěryhodné jsou pro vás sociální sítě?

- Jak důvěryhodné je sdělení podané prímo ředitelem školy nebo třídním učitelem?

- Jak důvěryhodná, spolehlivá a odborná by měla být vaše výroční zpráva?

\section{Výběr médii}

Při výběru médií vycházíme nejdřive ze znalosti o rozsahu a dostupnosti našich cílových skupin prostřednictvím jednotlivých médii. Cena za zveřejnění sdělení $v$ plánované kampani potom limituje frekvenci, $\mathrm{s}$ jakou a $\mathrm{v}$ jakých médiích budeme působit. Určitě vezmeme $v$ úvahu i další výhody a nevýhody využití média pro plánovanou komunikační kampaň.112

Pro zvážení účinku na povědomí publika musíme rozhodnout o:

- Dosahu (reach) = počet osob nebo domácností které budou v mediálním plánu kampaně ( $v$ určitém časovém období) nejméně jednou zasaženi.

\footnotetext{
${ }^{112}$ Napřiklad významná bude rychlost nasazení. Zvažte: aktualitu na www školy zveřejníme hned, komunikaci s komunitou na našem profilu na Facebooku a vyvěšení informace na nástěnce ve škole také zrealizujeme hned. Odvysíláni sdělení v regionálnim rádiu bude pomalejší a kampaň prostřednictvím billboardu bude mít ještě pomalejši nasazení.
} 
- Frekvenci (frequency) = kolikrát byla osoba či domácnost ve vymezeném časovém období zasažena sdělením.

- Dopadu (impact) = jedná se kvalitativní hodnotu dle použitého média a jeho parametrů vzhledem k cílové skupině. (př́iklad: typ časopisu, sociální sitě aj.)

Samozřejmě mezi dosahem, frekvencí a dopadem existují vztahy, které musíme brát $\mathrm{v}$ úvahu při plánování komunikační kampaně. Tím se dostáváme k poslední součásti $5 \mathrm{M}$.

\section{Měření výstupů komunikační kampaně}

V podstatě můžeme říci, že při vyhodnocování efektivnosti naší komunikace využijeme dostupné kvantitativní a kvalitativní ukazatele efektivnosti reklamy či marketingové komunikace.

Kvantitativní je možné rozdělit do dvou velkých skupin, podle toho zda měří DOSAH (reach) nebo DOPAD (impact) působení kampaně (Vysekalová \& Mikeš, 2018, s. 110-111). Není účelem této publikace podrobně popsat toto téma. Proto $s$ využitím uvedeného zdroje uvedeme jen přehled ve schématu a zájemce dále odkazujeme na tento zdroj nebo dostupné publikace Světlíka k reklamě (2017) a marketingové komunikaci (2016).

Využít můžeme řadu sekundárních dat, jež poskytuji samotná média nebo zdroje jako ČSÚ či SIMAR a samožrejmě potom i primární data z vlastních reportů a průzkumů.

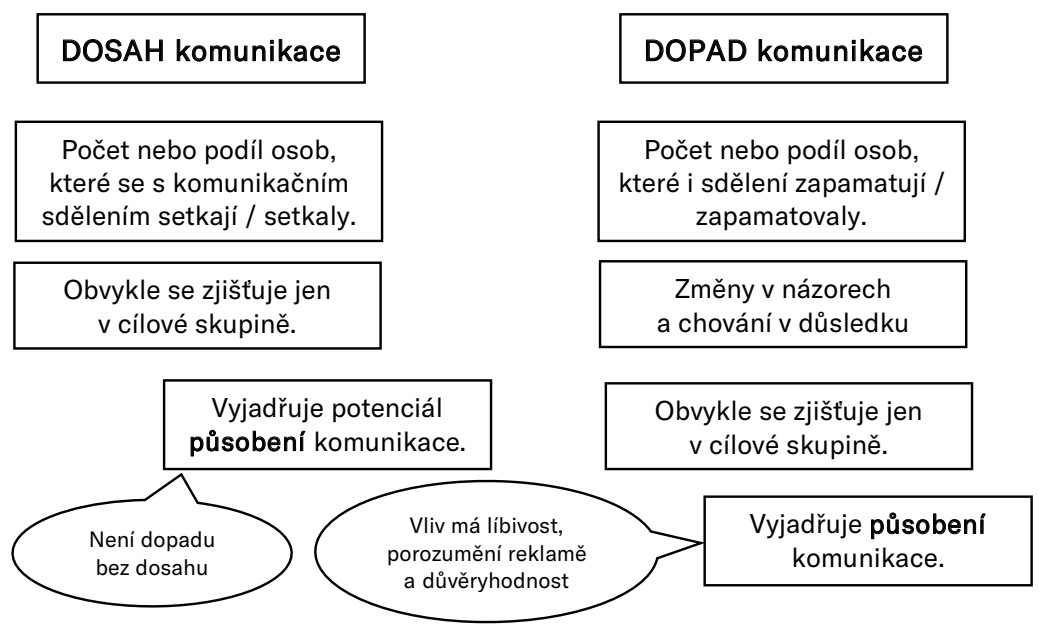

Obrázek 19: Dosah a dopad komunikace dle Vysekalová a Mikeš (2018) 


\section{!}

Samožrejmě hodnocení se bude odvijet od toho, jakých cílů chceme plánovanými a realizovanými komunikačními aktivitami dosáhnout. Proto na závěr této kapitoly zvažte následujíci výčet jako námět pro praxi:

- Vytváření povědomí. Je $v$ marketingu většinou spojeno $s$ aplikací placené reklamy, což je pro řadu škol mimo možnosti jejich rozpočtu zejména pro aktivity v masových médiích jako je televize. Školy si ale snad již dobře uvědomují, že velmi dobrým komunikačním kanálem je jejich web a řada jich začíná vhodně využívat i sociální média (SM) včetně marketingu na SM, který může být i velmi efektivní. Z masové komunikace některé školy využívají rádio a v podstatě téměř všechny mohou využít i formy $\mathrm{OOH}$ reklamy, minimálně s využitím jejich budov, plotů atd. Umíme propojit $\mathrm{OOH}$ prezentaci s internetem?

- Vytváření zájmu. Zde velmi dobře působí eventy (akce) školy ve spojení s informacemi opět na jejich www a sociálních sítích. Později např. i s reportováním akce s využitím videa a Youtube. Vzbuzený zájem vede přijemce sdělení $k$ tomu, že se chce více dozvědět (také naučit) o škole, jejím vzdělávacím programu, jejich aktivitách... a možná se i zúčastnit. Které akce školy jsou, a pro jaký komunikační účel vhodné?

- Rozšiřování informací. Jednou ze základních funkcí komunikace a reklamy je informovat. Přemýšlejte o tom, kde naposledy mohli zástupci cílové skupiny získat informace o vaši škole? Jak jim je prostřednictvím integrované marketingové komunikace doručujete? Odpovídaly doručené informace jejich potřebám a přáním?

- Vytváření image. Již jsme uvedli, že současným trendem je prezentování školy jako značky a že je to spojené i s utvářením pozitivní image školy. Odpovídá komunikace značky a vytváření image školy charakteristikám a specifiku média?

- Vytváření silné značky školy. Viz předešlý odstavec a samozřejmě příslušná kapitola této publikace. Jak jsme uvedli, je to nový přistup v marketingu škol.

- Stimulace „nákupu služby“, návštěvy školy, zapsání do kroužku, kurzu atd. Vedou naše akce „podpory prodeje“ k tomu, že rodiče zapiší žáky na školu, studenti se zúčastní... Jaký je zájem o vyzkoušení si školy během dne otevřených dveři na základě naši komunikace? Kolik ze zájemců a účastníků akce (kteři obdrželi informačni materiály a promo předměty...) se skutečně zapsalo? 
- Vytváření rozruchu (buzz marketing). Školy pro virální působení mohou využít $S M$, ale mohou se účastnit i dalších akcí v regionu či v obci aktivitami, které jsou podobné pouličním aktivitám firem s cilem upozornit na sebe a své výsledky veřejnost v regionu a obci. Jaký virální efekt mělo např́klad video o akci školy na vašem profilu na Facebooku nebo Youtube? Jakou odezvu měla publicita v rámci Public Relations o významném úspěchu školy?

- Získání pozornosti. Pro marketingovou komunikaci je důležité poskytovat informace užitečné pro cílové skupiny, jež hodnotí nabízený vzdělávací program a dalši služby školy a vedou přijemce sdělení k následnému věnování pozornosti škole a jeji značce atd. Například, kolik uživatelů si po zveřejnění aktuality o VZ školy skutečně stáhlo výroční zprávu za minulý rok? Kolik lidí se při dni otevřených dveři zastavilo u nástěnky prezentujíci nejúspěšnější žáky a absolventy?

\section{? Kontrolní otázky a úkoly:}

- Co znamená členění médií na placená, vlastněná a získaná média?

- Dokážete popsat hierarchický model účinků, kterým zákazníci procházejí, když dochází k transformaci jejich vztahu ke značce a ke vnímání značky?

- Co je to positioning?

- Jaké druhy apelů používáme při formulaci reklamního sdělení?

- Jak můžeme hodnotit výstupy komunikační kampaně?

\section{[DD Literatura:}

Kotler, P., \& Keller, K. L. (2013). Marketing management. Praha: Grada. Světlík, J. (2009). Marketingové řizení školy. Praha: Wolters Kluwer. Vysekalová, J., \& Mikeš, J. (2018). Reklama. Jak dělat reklamu. Praha: Grada. 


\section{KOMUNIKACE ŠKOLY S VER̆EJNOSTÍ NA INTERNETU}

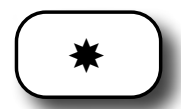

\section{Cíle:}

- Zařadit si strategii komunikace školy na internetu do integrované marketingové komunikace.

- Seznámit se s náležitostmi prezentace organizace na internetu.

- Získat podklady pro heuristickou analýzu www stránek školy.

- Pochopit význam využití sociálních médii pro komunikaci s cílovými skupinami.

- Získat doporučeni pro komunikaci školy jako značky na sociální síti.

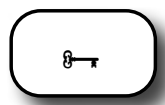

\section{Klíčová slova:}

strategie prezentace na internetu, web školy, copywriting, komunity značek

Čas potřebný ke studiu základního textu kapitoly je cca 15 minut + možnost rozšírení o studium externích zdrojů $\mathrm{z}$ internetu.

\section{Úvod}

Dnes si již vůbec nedovedeme představit komunikaci školy s veřejností bez využití internetu jako hypermédia. Marketing na internetu prošel za posledních 25 let dynamickým vývojem, je to nyní komplexní disciplína, jež je úzce svázaná s rozvojem ICT.

Ž̌ejmě v ČR první komplexní publikaci na toto téma s řadou výzkumných studií publikoval náš tým již před deseti lety (Eger a kol., 2010) a v úvodu jsme tehdy konstatovali s odkazem na šetření ÚlV, že většina škol má již své www stránky. Naopak v závěru u studie webů gymnázií ze dvou krajů 
jsme uvedli, že oficiálně nevyužívají sociální sítě, ale že to bude jistě trendem $\checkmark$ budoucnosti.

To, že všechny současné publikace $k$ marketingu věnují pozornost i marketingu na internetu je zřejmé a ostatně v rámci konceptu integrované marketingové komunikace (např. Janouch, 2020; Kotler \& Keller, 2013; Světlík, 2016), tomu nemůže být jinak. Zařazení problematiky reklamy na internetu, ale zejména komunikace prostřednictvím sociálních médii se potom objevuje jako nové téma i v současných zahraničních publikacích k marketingu školy (DiMartino \& Jessen, 2018; Lockhart, 2016a,b).

Výchozí bod i pro školy již před řadou let vyjádřil trefně Janouch (2010): „internetový marketing je již dnes významnější než klasický marketing tam, kde lidé využívají vyspělé technologie“. ${ }^{113}$

Na to navazuje i dalši důležité tvrzení dle Lockhart (2016b, s. 5): „Cena technologii pro zapojení studentü, rodičů a komunity do komunikace se školou se dramaticky snižila, a naopak dramaticky vzrostla snadnost, s jakou je možné tyto technologie využívat."

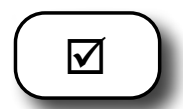

\section{Marketing na internetu ${ }^{113}$ zahrnuje celou řadu aktivit spojených s ovlivňováním, přesvědčováním a udržováním vztahů se zákaz- níky. Hlavní je komunikace.}

Pokud zvážíme to, že podle Eurostatu ${ }^{114}$ dosahuje tzv. penetrace internetem v ČR již cca 90 \% a že je prakticky u generací X a Z stoprocentní, pak je evidentní, že i marketing školy musí implementovat komunikační kanály spojené s internetem. V neposlední řadě je potřebné vzít v úvahu, že již v roce 2019 $60 \%$ českých uživatelů přistupovalo $\mathrm{k}$ internetu přes mobily.

POZNÁMKA: tím se v poznámce dostáváme i k tomu, že širším pojmem je digitální marketing, který v dnešním pojetí obsahuje outbound (snažíme se zasáhnout cílové skupiny), inbound (snažíme se, aby nás cillové skupiny našly, když na internetu vyhledávají), marketing v sociálních médiích a marketing spojený s mobilními technologiemi (smartphony, tablety aj.). ${ }^{115}$

\footnotetext{
${ }^{113}$ Použiváme také pojmy online marketing, e-marketing a širši pojem digitální marketing.

${ }^{114}$ Zajímavé a aktuální informace k uživatelů internetu najdete pro ČR na NetMonitor.

${ }^{115}$ Viz i např. Belch a Belch (2021).
} 
Zvažte:

Z které generace jsou rodiče vašich žáků a studentů a jaká média především využívají pro získávání informací? Jaké kanály, a i jaká koncová zařízení preferuji pro komunikaci s organizacemi?

\subsection{Přímý marketing a komunikace školy na internetu}

Nyní se můžeme krátce vrátit ke kapitole, kde stručně popisujeme toto „P“ marketingového mixu. $V$ marketingu škol sem řadíme zejména použivání pošty, telefonu nebo internetu k prímé komunikaci nebo k vyvolání odezvy či dialogu se zvolenými zákazníky / klienty či potenciálními zákazníky. U internetu se dřive jednalo zejména o komunikaci e-mailem, prípadně prostřednictvím www stránek a zde formulářu $\mathrm{k}$ dotazům nebo anket atd. Významná pozornost je nyní věnovaná využívání sociálních médií zejména pro tzv. WOM (viz i DiMartino \& Jessen, 2018).

Samožrejmě tato součást marketingového mixu je dnes využivána i v oblasti školství. Bohužel je zde patrné určité zaostávání proti marketingu z firemního prostředí a někdy jsou zvolené kanály a jejich nástroje použivány neefektivně.

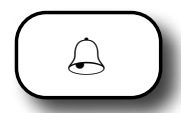

Zvažte:

- Jak vypadají pozvánky školy na schůzku rodičů nebo, nese e-mail školy na schválenou adresu cílového príjemce (pozor na GDPR) i stručnou marketingovou informaci?

- Která sociální média, a jak efektivně vaše škola využívá pro komunikaci s veřejností?

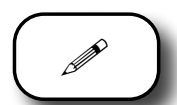

Vývoj využivání komunikace škol na internetu jsme sledovali na zvoleném segmentu gymnázií v ČR od roku 2010. Při psaní této publikace provedl autor rychlý průzkum využívání sociálních médií subjekty, jež nabízejí studijní programy zařazené pod gymnázium v Karlovarském a Plzeňském kraji. Jak jsme již uvedli, v roce 2010 žádná škola z tohoto souboru neměla oficiální profil na sociálním médiu propojený se svou www stránkou. Na konci školního roku 2020/2021 byla situace následující (stručně): 
- V Karlovarském kraji z původních 10 škol je nyní již jen 9, z nich jen 4 nemají odkazy na svých stránkách na své profily na sociálních médiích, ale z toho 2 oficiální profily mají, jen je neodkazují, zbylé 2 mají na Facebooku jen neoficiální skupiny. Počet sledujících byl od několik set až po 1600.

- V Plzeňském kraji je sledováno 15 subjektů, z toho 10 má odkazy na svých www stránkách i na sociální média, ze zbylých 5 jen jeden subjekt skutečně profil na sociální síti nemá. Počty sledujicích se pohybuji od několika desítek (u špatně vedených profilů) po 1800 u škol, které velmi aktivně pracuji s Facebookem. Objevuje se i využivání Instagramu a okrajově i Youtube, kde je ale zatím minimální počet odběratelů.

Jako dodatek je potřebné uvést, že všechny tyto subjekty využívají informační systémy jako Bakaláři či Škola online apod., ${ }^{116}$ což je také výrazná změna proti roku 2010 a samozřejmě efektivní cesta komunikace se současnými žáky a jejich rodiči. Je to nástroj podporující zejména interní cílenou komunikaci, protože se jedná o uzavřený přistup $\mathrm{k}$ informacím, na rozdil od otevřeného profilu na sociálním médiu.

\subsection{Strategie komunikace školy na internetu}

Současná koncepce vychází ze skutečnosti, že marketing je odrazem společenských a ekonomických podmínek a vyžaduje komplexní integrovaný prístup k zákazníkům, trhům, partnerům při respektování společenské odpovědnosti (viz i Světlík a kol. 2016). V plánování, řizení i vyhodnocování komunikace se zaměřujeme na potřebné dosahování synergie.

Marketingová komunikace obecně zahrnuje jak různé způsoby komunikace, které označujeme jako komunikační mix, tak komunikační prostředky a také nejrůznější techniky využivané v komunikaci se zákazníky.

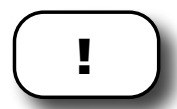

Marketingová komunikace na internetu patři mezi nejdůležitější a nejviditelnějši složku 4P. Internet ve spojením s Web 2.0, přinesl novou marketingovou komunikaci a rozširíil a obohatil komunikační kanály. Z hlediska organizací se rozrostla nejenom komunikace se zákazníky a stakeholdery, ale i vnitřní komunikace s využitím nových nástrojů.

\footnotetext{
${ }^{116}$ Dokonce se objevuje i využiváni aplikaci, u MŠ je to např. Twigsee, právě i pro podporu komunikace s rodiči.
} 


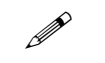

Pro informaci dále uvedeme možné členění forem a typů marketingové komunikace na internetu (dále viz např. Janouch, 2020):

- Reklama (katalogy, přednostní výpisy, PPC reklama).

- Podpora prodeje (slevy, soutěže, vzorky, věrnostní programy).

- Public Relations (novinky, články, virální marketing, sociální média).

- Př́mý marketing (e-mailing, online chat, webové semináře).

\section{$?$}

Co z uvedeného využiváme v oblasti školství a co využívá vaše škola?

Internet je interaktivní médium s neustále rostoucí základnou uživatelů. Díky jeho flexibilitě a kreativním možnostem projevu je ideálním prostorem pro marketingové vyjádření oslovujíci presně zvolenou cílovou skupinu.

Z hlediska marketingu se za specifické vlastnosti internetu považuji:

- Internet vytváři globální komunity se společnými zájmy.

- Komoditou internetu jsou informace.

- Internet je médium poskytujíci permanentní služby.

Všechny tyto specifické vlastnosti jsou důležité i v oblasti vzdělávání. Vytváření komunit žáků, učitelů, rodičů, absolventů a dalších uživatelů je nesmírně důležité (viz i úloha sociálních médií). Informace a vytváření znalostí jednoznačně souvisí se vzděláváním a zde úzce s e-learningem. A ano, napřiklad www stránky školy jsou k dispozici 24/7/365.

I pro školy bude platit, že „Komunikace se zákazníky je proces a jako takový se musí monitorovat, analyzovat a zlepšovat..." (Janouch, 2010, s. 21).

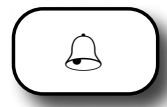

Uvádí se, že pro úspěšný marketing na internetu potřebujete realizovat následujíci tři kroky:

1. poskytnout zákazníkovi důvod pro návštěvu prezentace organizace na jejím webu, 
2. přesvědčit ho, že se mu vyplatí identifikovat se na webové stránce,

3. vyhodnotit získané údaje z jeho registrace.

Tím získáme data pro cílenou - personifikovanou komunikaci s ním, na které v současné době stavíme úspěch této komunikace proti např́klad masové neosobní komunikaci. Získané informace potom můžeme členit na ty, které nás informuji o „nákupu“ zákazníka, o jeho potřebách a práních, ale i jeho spokojenosti a o zákazníkovi samotném (Janouch, 2010).

***

\section{See-Think-Do-Care}

Ze strategického pohledu je aktuálně využíván přistup, který je označován výše uvedeným akronymem dle anglických slov. Pod každou součástí tohoto konceptu je zvažováno, co dělá uživatel - zákazník, a co by měla dělat či využívat organizace v marketingu na internetu / v digitálním marketingu. Přehledně to ukazuje následující schéma v obrázku 20.

Za autora myšlenky je uváděn Kaushik (2013) a v ČR je odkazováno na jeho prezentaci v Praze z roku 2014 (Marketing Festival). Koncept je někdy prezentován jako revoluce $v$ digitálním marketingu, ale spiše je možné tvrdit, že vychází ze dvou základních marketingových principů (srovnej s Kotler \& Keller, 2013), které ve vztahu k marketingu na internetu zdůrazňuje. Jsou to:

1. Orientace na zákazníka (včetně kvalitní segmentace a positionningu).

2. Plánování, realizování a vyhodnocování marketingové komunikace podle fází procesu rozhodování o koupi s modifikací pro internet.

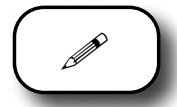

Co je podstatou? (v dalším textu budeme mírně aplikovat pro školu)

Výchozím bodem je, že máme ujasněné své poslání, tedy známe odpověd’ na otázku, proč a pro koho tu naše škola a její vzdělávací služba je, a jaké hodnoty a komu přinášíme.

\section{SEE}

Je první fáze tohoto prístupu a znamená to, že musíme provést účelné cílení na všechny relevantní segmenty našich současných i potenciálních zákazníků / klientů, a to v počáteční fázi jejich kupního rozhodování. Řeši problém, mají potřebu či prání? Potřebují něco vyřešit v oblasti vzdělávání? 
Musíme si odpovědět na otázku, jak jim můžeme sdělit, že to umíme nabídnout či řešit, a jak to může vést $k$ jejich (velké) spokojenosti? Samozřejmě nás nejvíce zajímá komunikace s relevantní veřejností.

Vhodně podané žádané informace na webu školy a dnes i jejich profilech na sociálních síti (a aktivní komunikace) patři do této fáze. $V$ této fázi také využiváme vhodných článků (blog, novinky), obrázkových galerií, ale i vtipné relevantní video.

Zjištujeme si (mapujeme) zejména množství interakcí, nové ohlasy, procento návštěv z určitého komunikačního kanálu školy atd.

\section{THINK}

Známe již „své“ cílové skupiny a zaměřujeme se na potřebu či problém, který chtěji řešit. Zákazník / klient si již ujasňuje potřebu či prání a potřebuje konkrétnější informace, jak najit pro něho výhodné řešení.

Pokud se zákazník pohybuje na relevantních webech, může jej, mimo jiné, dobře oslovit kontextová reklama (pro školy to ale není typické, tato reklama se samozřejmě zadavatelem platí). Škola může dobře použít newsletter. Pokud pro jeho odeslání splňuje i podmínky dané GDPR.

Protože YouTube kanál se proměnil ve „vyhledávač“, kde také řada lidí hledá odpovědi. Video s účelnou informací může těmto hledajícím účelně napovědět a může také ukázat, že vaše škola umí problém řešit apod. Ještě lepší je na www odvyprávět př́běh, který dokumentuje, že podobnou potřebu či problém umite vyřešit ke spokojenosti všech zúčastněných.

Zejména zákazníci z generace $Y$ a mladší jsou zvyklí na internetu hledat recenze. Zejména ty mladší oslovuji i sdělení o tom, že vaše škola je i společensky odpovědná (CSR), věnuje pozornost přirodě a ekologii atd.

$V$ této fázi roste úloha měření. Pokud použiváte reklamu, tak například ukazatel CTR ${ }^{117}$ aj., počet navštívených stránek, počet shlédnutí videa atd.

\section{DO}

Možný budoucí zákazník / klient se již rozhoduje, ale také porovnává nabídky (navíc na internetu „je to tak snadné, ne?").

Protože zákazník již kliká (vstupuje na stránky školy, stahuje si dokumenty s nabídkou aj.), ale může být stále ještě nerozhodnutý a nedokončit požadovanou akci, přicházíme s personalizovanou nabídkou (pokud právě máme

\footnotetext{
${ }^{117}$ Míra prokliku či CTR (z anglického click through rate) se označuje poměr mezi počtem kliknutí na reklamu (resp. počtem prokliků) a celkovým počtem zobrazeni reklamy.
} 
kontakt a povolení jej oslovit, viz výše „tři kroky“). Škola může využít dotazů získaných webovým formulářem, či jen e-mailem přes „napište nám“ apod. Firmy zde díky sofistikovanějším prístupům využívají i tzv. retargeting, ale u regionálního školství je to zatím spiše neobvyklé.

Z hlediska školy je otázkou, zda můžeme nabídnout další, zvláštní nabídku, dárek? Můžeme použít i online komunikaci např. s využitím Skype nebo nabídnout kontakt a osobní komunikaci přes mobilní telefon. Jak jste schopni reagovat na sociální síti a do kdy (viz dále podkapitola k SM)? Snažme se opět pracovat $s$ potřebami a práním zákazníků, jak naše nabídka odpovídá jejich pohledu podle tzv. „4C"?

Pokud chceme zjistit, jak jsme efektivní, musíme opět měřit (zaznamenávat a vyhodnocovat) aktivity. Je to i nezbytným předpokladem pro přesnější cílení a zlepšování komunikace. Obecně je hlavním ukazatelem konverze a dosažení „zisku“, ale sledujeme i to, proč jsme byli neúspěšní. Otázkou je, co můžeme ve školství brát jako zisk. Jednoznačné to je, pokud je žák či student zapsán do školy, zakoupí si kurz či jinou doplňkovou službu. Nicméně, v oblasti veřejného školství nebudeme použivat zisk tak, jako ve firemním prostředí, ale je vhodné si nastavit tzv. klíčové indikátory výkonu (KPIs) dle specifika naší školy.

\section{CARE}

Původní model marketingové komunikace, tzv. model AIDA, je dnes rozšiřován napríklad na AIDAS, kde $S$ = satisfaction. Tento pátý prvek je zaměřen na ponákupní komunikaci se zákazníkem a péči o něj. V oblasti školství je spokojenost zákazníků zejména u žáků, rodičů a učitelů i ostatních pracovníků školy to nejpodstatnějši a je to spojené i s posláním organizace. Pro firemní prostředí potom platí, že udržet si již získaného zákazníka bývá o mnoho snadnější než získat nového.

Máte připravené klientské prostředí a komunikaci tak, aby si uvedené cílové skupiny pripadaly jako VIP?

Pro DDM, ZUŠ ale napřiklad i pro MŠ (více dětí v rodině) platí, zda se dokáží vhodně se prípomenout se svou nabídkou a podpořit tak například „opakovaný nákup“.

Protože žáci a studenti jsou na škole řadu let, je vhodné myslet na budování dlouhodobých vztahů a nejenom na nějaký okamžitý „zisk“. Jsme schopni s nimi také komunikovat dle tzv. životního cyklu produktu a zákazníka? (prvňáček - žák deváté třídy, nastupující do primy - maturant)? 
Školství je specifické, hodnota vaší vzdělávací služby se projeví v dlouhém období. Dávaji absolventi vaší školy s odstupem řady let do školy i své děti?

Niže uvedený model pracuje se zákaznickým cyklem. Pro každou jeho fázi stanovujeme cíle, upřesňujeme cílové skupiny, volíme adekvátní komunikační kanály a nástroje, připravujeme obsah sdělení a realizujeme měření výstupů aktivit.

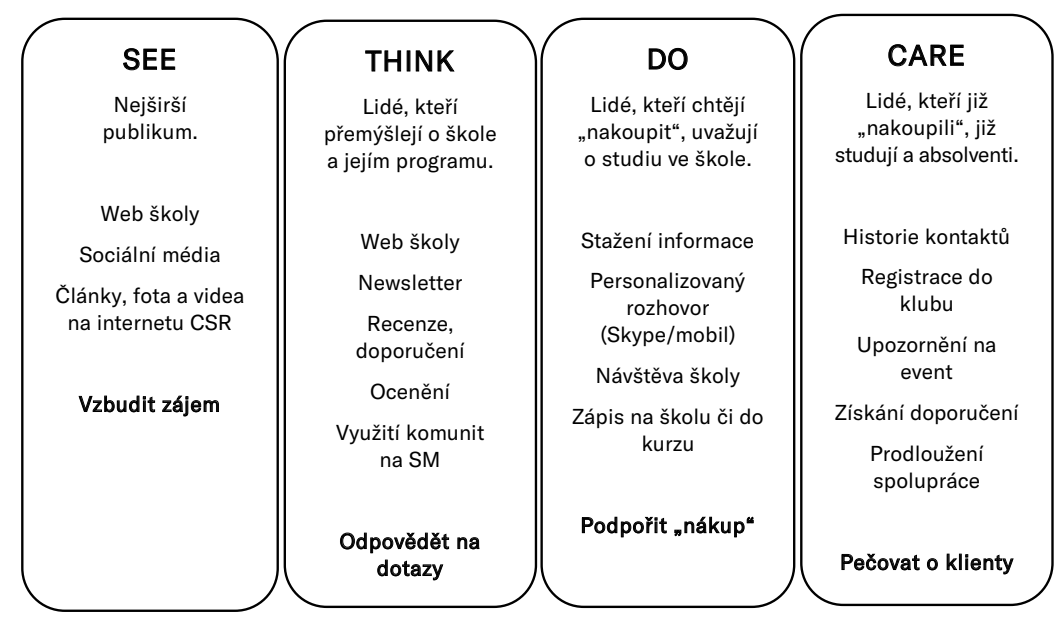

Obrázek 20: Model See-Think-Do-Care v úpravě pro marketing regionálních škol

Využití placené reklamy na internetu by patřilo zejména do fáze THINK a DO, ale školy v regionálním školství ji nevyužívají v takovém rozsahu jako firmy $\checkmark$ podnikatelském prostředi. Nicméně najdeme výjimky, a kromě kontextové reklamy a PPC v Google Ads a S-klik ${ }^{118}$ se využívá reklama například na Facebooku. ${ }^{119}$

***

Jak jsme již uvedli výše, strategie v oblasti marketingu na internetu či digitálního marketingu musí vycházet ze strategie organizace a pro marketing je kličovým integrace všech aktivit.

\footnotetext{
${ }^{118}$ Google Ads a S-klik jsou dva rozhodujici systémy, kde se pro ČR realizuje reklama ve vyhledávání.

${ }^{119} \mathrm{Je}$ také pravda, že v publikaci k marketingu školy DiMartino a Jessen (2018) reklamě, a to i na internetu, věnuji významnou pozornost. Uváději (s. 87), že ve velkých městech, kde je konkurence mezi školami je již při získávání žáků marketingová kampaň na internetu nezbytnou nutností.
} 
Protože marketingové strategii se podrobně věnujeme v předešlých kapitolách předložené publikace, připojíme zde již jen několik poznámek ke strategii digitálního marketingu.

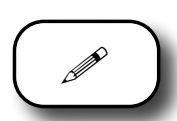

Napřiklad Kingsnorth (2019) samozřejmě vychází z toho, že si musite stanovit své marketingové cíle a dobře znát své zákazníky i konkurenci. Potom doporučuje věnovat pozornost:

- Základním „4P“.

- Porterově analýze pěti sil.

- Značce a její poziční mapě (porovnání s konkurencí).

- Celoživotní hodnotě zákazníků (zaměření na zákazníka v dlouhodobé perspektivě).

- Segmentaci (zacílení na relevantní cílové skupiny).

- Portfoliové analýze (používá BCG a souvisí to s analýzou produktu na trhu).

Opět za důležité pokládá integraci „digital“ do celkové marketingové strategie při věnovaní pozornosti značce, vizi organizace, její kultuře, ale i zaměření na inovace a klíčové indikátory výkonu (KPIs). Součástí je samožrejmě i zvažování finančního zabezpečení plánovaných aktivit. Pozornost musíme věnovat i trendům v chování zákazníků a vývoji technologií, jež ovlivňují marketing na internetu. Za poslední fázi pokládá zaměření na kontinuální zlepšování.

POZNÁMKA: ke všem výše uvedeným bodům najdete základní informace v kapitolách této publikace (stručný popis BCG matice je v přiloze G).

\subsection{Prezentace školy na internetu a www stránky školy}

Výhodou pro oblast školství je to, že základní prezentace na www je již pro školy standardní záležitostí, dostupnost internetu v domácnostech v ČR je nyní i po pandemii COVID-19 vysoká a dovednosti ve využivání ICT u mladší a střední generace uživatelů jsou velmi dobré, dokonce se významně zvýšily i u seniorů.

WWW stránky organizace můžeme chápat jako základní podmínku pro uplatňování marketingu na internetu pro konkrétní organizaci. Velmi zjednodušeně uvedeme, že základem této prezentace je několik vzájemně provázaných webových stránek. 


\section{!}

Prezentace školy na internetu potom musí vycházet ze strategie marketingové komunikace školy. Tvorba internetové prezentace by neměla vycházet jen z nahodilého impulzivního rozhodnutí, ale musí být postavena na základě uvážlivého promyšlení. V zásadě lze postup shrnout do třech základních kroků:

- Pečlivě analyzovat a definovat své cíle.

- Určit cílové skupiny uživatelů.

- Využít porovnání se s konkurencí.

Marketing na internetu musí vycházet $z$ celkové marketingové strategie a stanovených cílů marketingové komunikace. Těmi cíli v oblasti školství určitě bude posílení image organizace, splnění informačních povinností, získání žáků či studentů, podpora vzdělávacího procesu atd. Dnes sem určitě pridáme i prezentaci školy jako značky.

\section{$\square$}

Za klíčové považujeme rozhodnutí o tom, zda web školy budete vytvářet sami vlastními silami nebo tento úkol budete outsourcovat, tedy svěřite projekt tvorby webu externí specializované agentuře či freelancerovi z oblasti digitálního marketingu.

Současně je potřebné brát v úvahu i to, kdo jej bude dále spravovat $\mathbf{z}$ hlediska ICT a kdo bude administrativním správcem a kdo všechno tvůrcem obsahu webu školy. Případně, jak bude probíhat dále inovace webu v kooperaci s tvůrcem a správcem stránek.

(ن)

Známe přiklady, kdy weby škol úspěšně vytvářeji a spravuji ICT koordinátoři a další členové sboru školy např́iklad i s využitím opensource WordPress. ${ }^{120}$

${ }^{120}$ WordPress, viz např. https://cs.wordpress.org/ 
(ே)

V letech 2020-2021 jsem v projektu NiDV (NPI) lektoroval kurz zaměřený na marketing školy, jehož součástí bylo i hodnocení webů škol. Setkal jsem se nejenom s dílčími chybami, ale i s velmi zastaralými weby, a dokonce i se špatně spravovaným obsahem stránek školy.

\section{】}

Projekt tvorby nového webu není jednoduchá věc, my se zde soustředíme na základní informace $\mathrm{k}$ webu školy a představíme si, jak si můžete váš současný web ohodnotit. Nicméně, pokud uvažujete o novém webu, v týmu by měli být: vedoucí projektu, programátor/webmaster, analytik, grafik, copywriter, specialista na internetový marketing (viz dále Janouch, 2020).

Obecné zásady pro web organizace:

- Dodržujete pravidla webdesignu a webové standardy.

- Respektujte zásady jednotného vizuálního stylu.

- Podpořte př́stupnost webu.

- Akceptujete varietu koncových zařizení (web dnes musí být responzivní).

WWW stránky školy (web školy) nejsou jen její vizitkou, ale především musí nabizet důvod k návštěvě relevantním cílovým skupinám (reason to buy). Definování účelu stránek je kličové.

\section{„Skutečný úspěch stránek se odvíjí od toho, nakolik splňuji svůj} cíl.“ (Winmanová, 2004)

Stránky musí mít pro návštěvníka nějaký prospěch, pro různé cílové skupiny by měl být diferencován, měl by být dostatečně motivující a ideálně i odlišný od nabídky konkurence. Janouch (2020, s. 61) doporučuje položit si následující otázky:

\section{$?$}

- Proč by se měl návštěvník stránek stát našim zákazníkem? (studentem školy, člověkem, který bude o ni pozitivně mluvit) 
- Kde je ten impuls, který ho k tomu přiměje?

A samožrejmě dobrou a často opakovanou radou je, ptát se na to prímo zástupců cílové skupiny.

\section{$\square$}

Základní evaluaci vašeho webu si můžete udělat s využitím tzv. heuristické metody, tedy expertním hodnocením podle dané specifikace.

(ن)

Tím expertem by mohl být váš ICT koordinátor, který je jistě kompetentní v oblasti ICT a obecně zná problematiku webové prezentace. Protože se doporučuje metoda čtyř oči (dva lidé se musí shodnout na hodnocení), může být tím druhým expertem ten, kdo si prostuduje předloženou publikaci a bude se orientovat v základech marketingu pro školy.

Dále uvedeme možné přístupy pro praktické využití:

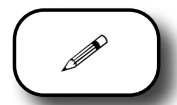

Za zakladatele této metody je považován Nielsen (1994), který navrhl původně deset základních parametrů, jež se mají hodnotit. Tak, jak se internet a ICT vyvijely, tak se spolu s vývojem marketingu na internetu objevovaly propracovanějši metodiky a s rozvojem www stránek je využivaly a využivají i soutěže o nejlepši weby, které nám přinášejí příklad dobré praxe a vlastně i spoluutváŕí trendy v této oblasti (viz The Webby Awards a pro ČR WebTop100). ${ }^{121}$

Pro nás je ale důležité použít uvedenou metodu v aplikaci pro vzdělávací instituce.

V ČR jednu z prvních metrik publikoval Neumajer (2007), který prezentoval i tzv. autoevaluačního asistenta, který je vlastně průvodcem kategorií a položek hodnocení.

${ }^{121}$ The Webby Awards: https://www.webbyawards.com/, WebTop100: https://www.webtop100.cz/ 
(ن)

Novější alternativou je (byla) soutěž Schoolweb, kde také najdete kritéria dobrého webu vytvořená v roce 2018 ke stažení (https://www.scoolweb.cz/ kriteria-dobreho-webu), mezi hlavní oblasti patři:

1. Otevřenost školy vůči veřejnosti.

2. Uživatelská přívětivost - použitelnost, přehlednost, přístupnost a srozumitelnost.

3. Bezpečnost.

4. Grafické zpracování - grafika, design, estetický dojem.

Samožrejmě si můžete prohlédnout vítěze v kategoriích ZŠ neúplně organizované, ZŠ plně organizované, střední školy a oceněni veřejností.

Naše metodika (Eger a kol., 2010) vycházela z hlavních faktorů posuzovaných dle WebTop100, které korespondovaly i s faktory dle The Webby Awards. Jednalo se 0 ( $v$ závorce váha faktoru):

- $\quad$ Použitelnost (25\%).

- Grafický design (15\%).

- Technické řešení (10\%).

- Marketing (25\%).

- Přínos pro uživatele (25\%).

Tak, jak se postupně vyvijely požadavky na webové prezentace organizací na internetu, tak jsme přizpůsobovali dilči položky. Například důraz na zpracování kódu, responzivnost webu, rychlost načitání v mobilu, zapojení SM (odkaz z www stránek školy), https, GDPR aj. Kromě expertního posuzování využiváme i nástroje Google developers aj. To znamená, že některé položky jsou hodnocené i nezávisle pomocí relevantních technologických nástrojů.

Protože tato publikace je o marketingu, uvedeme zde dílčí položky k hodnocení www se vztahujících faktorů, jež aktuálně při posuzování webu školy využiváme. Položky hodnotíme od $0=$ není splněno, až po 5 bodů = excelentní (Nielsen původně použil 0-4).

Hodnocení provádí nezávisle dva experti a pokud se velmi liší v nějaké položce, dochází $k$ dohadovacímu řízení, tedy musí se zjistit proč $k$ tomu došlo, a potom hodnocení případně upravit (může se stát, že dojde k dílčímu přehlédnutí). Pravdou je, že po vyhodnocení desítek webů škol má hodnotitel bohaté zkušenosti, a to se potom promítá i do jeho práce. 
Obrázek 21 prezentuje položky dvou důležitých oblastí našeho nástroje. ${ }^{122}$

\section{Marketing}

- Marketingová přesvědčivost

- Vhodná volba domény

- Viditelnost ve vyhledávačich

- Provázanost s ost. informačními kanály

- Sociální média

- Kvalita textů, foto, video

\section{Př́ínos pro uživatele}

- Směr komunikace

- Možnost publikování nebo SM

- ŠVP a info o něm

- Historie, vize školy, VZ

- Info pro rodiče

- Aktuálnost

- Školní časopis

- Doplňkové materiály ke studiu

- E-learning (LMS)

Obrázek 21: Hodnocení webu školy, marketing a přinos pro uživatele

Na závěr této kapitoly je možné uvést i s odkazem na Janouch (2020), Kingsnorth (2019) či Strauss a Frost (2012), že je vhodné s využitím této, či podobné metodiky, sledovat i stránky konkurence, poučit se a čerpat náměty pro zkvalitňování vlastní práce.

$(-)$

\section{Máte responzivní web? Je webová stránka optimalizovaná pro mobily?}

- Použijte: https://search.google.com/test/mobile-friendly

Jak rychle se načitá? Nikdo na mobilu nechce dlouho čekat...

- Použijte: https://developers.google.com/speed/pagespeed/insights/

- nebo: https://www.thinkwithgoogle.com/intl/en-gb/feature/testmysite/

\section{- Optimalizace pro vyhledávače}

SEO, ${ }^{123}$ neboli optimalizace pro vyhledávače je vlastně optimalizace $\mathbf{k}$ vyhledávání uživatelů (Janouch, 2020). Hlavním cílem celého procesu je zlepšení pozice ve vyhledávání, ale klíčová je celková optimalizace stránek tak, aby byly prínosné pro uživatele internetu, aby na nich našli to, co hledají

\footnotetext{
${ }^{122}$ Vlastní nástroj je v Excelu a eviduje body za položky, průměry za hodnotitele a výstup vynáši do grafu.

${ }^{123}$ Search engine optimalization.
} 
a hlavně, aby se chtěli vracet. Návštěvníci se dostávají na stránky školy tak, že zapíši prímo URL adresu stránek, hledaji pomocí klíčových slov nebo odkazem (refferal) z relevantních odkazujících stránek.

Optimalizace je složitou záležitostí využivající on-page i off-page faktory a ve firemním prostředí se jí věnuje velká pozornost. ${ }^{124}$ Specificky u regionálního školství se aktuálně jeví, že není tak důležitá jako v oblasti podnikání. Stránky školy v regionálním školství se obvykle dobře najdou, pokud máte vhodnou doménu nebo i dotazem s typem školy (mateřská, základní, střední) a obce. Kromě skutečně velkých měst v ČR, kde je škol více, budete vysoko v přirozeném vyhledávání. A protože školy většinou neinvestuji do reklamy na internetu (PPC systémy), není nutné ani z tohoto důvodu optimalizovat.

Co naopak je vysoce doporučené, je upravit si profil školy v Google a na Seznamu (je to zdarma a využijte dostupné položky ke kontaktům a mapy...).

Pro zájemce o SEO je možné odkázat na mnoho zdrojů na webu nebo např́klad na publikaci Janoucha (2020, s. 87-142).

\section{Copywriting - tvoření obsahu stránek}

Copywriting je disciplínou, která se zabývá efektivním psaním obsahu www stránek. Účelem je vytvořit takový obsah, aby podporoval SEO, ale zejména aby svou informační hodnotou a atraktivností oslovoval cílovou skupinu. Obsah stránek je přitom kličový i pro off-page faktory, protože se na něj vhodně váží i relevantní hyperlinky.

Je evidentní, že se jedná o postupy, které staví na poznatcích a principech z marketingu na internetu. Je to dále spojeno i s kreativitou a s vhodným propojováním textových a obrazových prvků (formát, ale i styl) stejně jako se znalostí jazyka (sémantika, gramatika...).

Je potřebné zdůraznit, že copywriting z hlediska marketingu musí ctít celkovou strategii firmy a integraci marketingu na internetu do dalšich marketingových aktivit.

Z uvedeného i plyne, že cilem je napsat text a sestavit design stránky tak, aby oslovily cílovou skupinu a vedly je k akci. Janouch (2020, s. 109) doporučuje si nejdřive ujasnit následujíci:

\footnotetext{
${ }^{124}$ Nicméně například Lockhart (2016b) upozorňuje na potřebu relevantnosti obsahu stránek školy a jeho kvalitu a doporučuje pracovat s kličovými slovy, zpětnými linkami ze SM atd.
} 
- Za jakým účelem je text psán.

- Co se má čtenár dozvědět.

- Čím ho chceme zaujmout.

Dodáme, že opět je podstatné zvažovat pohled zákazníka. Pro koho text píšeme, kdo, či která cílová skupina bude čtenářem? ${ }^{125}$

Velmi důležitým pojmem se stává MDA, tj. Most-Desired-Action. Je to něco, co chceme, aby návštěvník na našich stránkách vykonal (registrace do newsletteru, prohlédnutí určité stránky, stažení dokumentu, odeslání formuláře, objednávka kurzu, ...).

(-) Několik námětů pro psaní textu pro web:

Zvažte, jakými argumenty (apely na rozum i emoce!) budete oslovovat čtenáře. Doporučuje se použivat poutavý nadpis (ale ne clickbait ${ }^{126}$ ) nejlépe do 8 slov, použivat akční slovesa, zaměřit se na něco, co přináší skutečnou výhodu pro čtenáře, psát tak, aby to oslovovalo zvolenou personu (zástupce cílové skupiny). Rady, tipy, humor, relevantní čísla atd., to je to, co čtenáre oslovuje. Jsme také v době, kdy mobily jsou na prvním místě, tedy text musí být stručný, vhodné jsou i obrázky a info-grafika, ale pozor opět na prezentaci v mobilních telefonech. Strukturujte text a používejte spiše kratši věty.

Na webových stránkách školy z hlediska Public Relations je vhodné umístovat relevantní doporučení, rady a návody pro žáky či studenty a jejich rodiče, musíme aktivně pracovat s aktualitami a novinkami, samožrejmě využiváme i „tiskové zprávy“ o škole a jejích úspěších, vhodné je pomocí log a hyperlinek upozornit na spolupráci s relevantními dodavateli a odběrateli (pro ŽS tím myslíme spolupracujíci MŠ a odkazy na SŠ, kam řada absolventů odchází atd.). Řada škol již vhodně pracuje s certifikáty kvality (viz doklady značky) a jiným oceněním školy či jejích učitelů a žáků. Samozřejmě můžeme využít i anket či formulářu $k$ interakci, a to přímo $z$ webu nebo $v$ uzavřeném informačním portále školy. Další vhodné položky viz výše u hodnocení přínosu pro uživatele. ${ }^{127}$

\footnotetext{
${ }^{125}$ Důležitost obsahu se zaměřením na prezentováni školy jako značky vyzdvihují např. DiMartino a Jessen (2018).

${ }^{126}$ Clickbait = nehodnotné nalákání čtenárư lákavým nadpisem, kde samotné sdělení často neobsahuje hodnotné informace, které uživatel hledá.

${ }^{127}$ Otázkou je, zda udělat sekci časté dotazy (hodila se v době pandemické krize) nebo sekci s referencemi.
} 


\section{!}

„Webové stránky mají výhodu v možnosti přesné kontroly toho, jaké informace se dostanou $k$ zákazníkům a $v$ jaké podobě, jak po formální, tak obsahové stránce“" (Janouch (2020, s. 266). Na druhé straně jsou sice základním, ale jen jedním z komunikačních prostředků na internetu, prostřednictvím kterého se utváři vztah s veřejností. Tím se přesouváme od www stránek školy ke komunikaci s využitím sociálních médií, jež je trendem i pro regionální školy (viz i DiMartino \& Jessen, 2018).

\subsection{Komunity značek na sociálních médiích}

\section{Úvod}

Masivní využívání sociálních médií výrazně mění komunikaci lidí v současné společnosti. Využívání mobilního připojení spolu s rozvojem sociálních sítí jako Facebook, Instagram, Twitter či Linkedln nebo média jako YouTube otevřelo nové marketingové přiležitosti pro komunikaci organizací a jejich značek s jejich zákazníky, a to současnými i potencionálními. Přitom další rozvoj ICT jistě přinese dalši změny v komunikaci lidí prostřednictvím ICT.

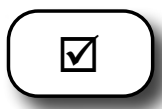

Sociální média ${ }^{128}$ (SM) jsou založená na webových službách, které umožňují jednotlivcům vytvářet veřejný či částečně veřejný profil uvnitř ohraničeného systému, vytvářet seznam dalších uživatelů, se kterými jsou ve spojeni (sdilí) a dále zobrazovat jejich seznam spojení s dalšími, která mohou být vytvořena uvnitř tohoto systému.

Asi jednodušeji: „SM média je termín používaný k popisu typu médií, která jsou založena na konverzaci a interakci mezi lidmi online.“ (Strauss \& Frost, 2012, s. 306)

„Sociální média jsou online média, kde je obsah (spolu)vytvářen a sdílen uživateli. Sociální média se nepřetržitě mění tím, jak se mění jejich obsah a také přidáváním mnoha funkci.“" (Janouch 2014, s. 299) Sociální sítě jsou, potom jednou z forem sociálních médií.

\footnotetext{
${ }^{128} \mathrm{~V}$ nové publikaci použivá Janouch $(2020$, s. 258) pojem sdílená média a uvádí, že jsou to online média, kde je obsah (spolu) vytváren a sdilen uživateli. Uvádí též, že jsou místem „kolektivni moudrosti“. Dodáváme, že občas při šiřeni fake news i opakem.
} 
Pro marketing na sociálních médií je dobré si uvědomit, že sociální sítě nebyly původně prímo vytvořeny $\mathrm{k}$ marketingovým účelům a jejich výhodou proti jiným klasickým médiím je, že Ize na nich díky technologii Web 2.0 dosáhnout obousměrné interaktivní komunikace. $V$ otevřené obousměrné komunikaci potom můžeme opět získat informace o potřebách a práních našich cílových skupin a ty potom lépe uspokojovat poskytováním služeb, jež budou pro ně hodnotné.

V současné koncepci integrovaného marketingu je velmi žádoucí elektronický WOM (eWOM) a některé studie ukazují, že může být účinější, než použití tradičních nástrojů reklamy právě proto, protože doporučení prátel na síti má vyšší hodnotu a důvěryhodnost, než tradiční komunikace reklamou. ${ }^{129,130}$

Zvažte, že SM zjednodušila možnost komunikace o vaší škole $z$ řady pohledů či způsobů, ale naopak umožnila, že tato komunikace může být v určitém ohledu (přistupu) i velmi komplexní (podle Lockhart, 2016b). SM otevřela nové cesty, kterými školy mohou poskytovat informace, odpovídat na dotazy, také vyvracet fake news či desinformace, a to rychle a poměrně rozsáhle.

\section{Komunity (značek) na sociálních médiích}

\section{Prostřednictvím sociální médií se organizace snaží podporovat své} značky vytvářením a šírením obsahu, který je zákazníkủm a dalším potenciálním zájemcům pozitivně představuje. Prostřednictvím vytváření komunit na sociálních sítích jako je například Facebook nebo Instagram potom firmy poskytují již pro získané prátele a pro (potenciální) zákazníky zajímavý obsah a snaži se udržovat jejich interakci a vazbu se značkou a samožrejmě je vést až k nákupu daného produktu, který je značkou prezentován. V oblasti regionálních škol, podobně jako u firem, jde především o: ${ }^{131}$

- Zviditelnění školy (a její značky).

- Zvyšování povědomí o naší škole (značce).

- A nakonec o propojení či budování sounáležitosti členů komunity se školou.

Členové těchto komunit (followers) potom i sami dále mohou přispívat $\mathrm{k}$ vytváření obsahu spojeného se značkou, ale zejména $k$ jeho šírení $s$ využitím zvolených sociálních sítí apod. Výzkumy prokázaly, že se tak skutečně zvyšuje

\footnotetext{
${ }^{129}$ Vzhledem k tomu, že publikace je na prvním místě určena pro regionální školy, nebudeme se placené reklamě na sociálních sítích věnovat. Odkazujeme na dostupné publikace Janouch (2020) nebo Semerádová, a Weindlich (2019).

${ }^{130}$ Ostatně Janouch (2020, s. 259) uvádi, že sdílená média nejsou určena k propagaci a reklamě.

${ }^{131}$ Školy se také naučily web školy a připadně i profil na Facebooku využivat i pro nábor nových zaměstnanců. Při cileni na mladé generace, to může být velmi efektivni (zajímavá studie v kontextu ČR: Mičík a Kunešová, 2021).
} 
zviditelnění značky, povědomí o ni i míra propojení (potenciálních) zákazníků se značkou. Navíc marketérům takové komunity poskytují cenné informace a oni potom mohou precizněji segmentovat cílové skupiny a realizovat vhodnou komunikaci s relevantními skupinami uživatelů SM (Eger, \& Mičík, 2019).

Tyto virtuální komunity (De Vierman a kol. 2017) se od klasických komunit spojených napřiklad se školou odlišuji napřiklad tím, že zde není geografické omezení a komunikace je značně nezávislá i na čase. ${ }^{132}$ Navíc současné uživatelsky přivětivé prostředí napřiklad na Facebooku a vysoká penetrace internetem, stejně tak jako vysoké zapojení uživatelů zejména $Z$ generací $X, Y$ a Z, skutečně otevřely tyto moderní kanály interaktivní komunikace prakticky všem, kteři jsou se školou nějako spojeni a chtěji být s ní spojeni.

\section{2}

Obecně je uváděno, že virtuální komunity značek maji 3 hlavní komponenty:

- Sounáležitost, kdy členové komunity cítí určitou sounáležitost $k$ sobě navzájem a odlišuji se tím také od ostatních.

- Sdílení tradice a také často i rituálů spojených s organizaci a její značkou.

- Nakonec i určitou odpovědnost vǔči značce, její komunitě a členům této komunity.

Členové sdílí společný zájem a účastní se v komunitě čtením zpráv, lajkováním, sdílením či přeposiláním obsahu, ale i jeho vytvářením prostřednictvím komentováni atd. Tyto nové virtuální komunity jsou také více otevřené a snadněji dosažitelné i pro dalši zájemce z široké veřejnosti. Může dále docházet ke zvýšení dosahu komunikace na internetu, kdy někteři uživatelé z této sítě a komunity, kteři jsou se značkou školy spojeni, jsou ochotni sdílet obsahy nebo i vytvářet dalši i mimo profilovou stránku školy na sociální síti. ${ }^{133}$

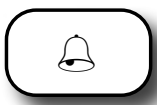

\section{Povědomí o značce může být měřeno prostřednictvím řady metrik.} Nejjednodušší je např́klad na Facebooku počtem lidí, kteři zprávu lajkovali, sdíleli nebo komentovali. Je také potřebné odlišovat pozitivní a negativní zpětné vazby a analyzovat např́klad tón komunikace (sentiment), hodnotit

\footnotetext{
${ }^{132} \mathrm{Na}$ druhé straně se vedou diskuse $\mathrm{k}$ tzv. Dunbarovu čislu (150), kolik lidí můžete skutečně dobře znát? Viz studie Eger (2019).

${ }^{133} \mathrm{Cca} 10 \%$ lidi, kteři vykazuji vysokou míru komunikace (Mutinga a kol., 2017), je možné pokládat za potenciální influencery.
} 
apely a reakce na ně, ale i efektivnost akcí včetně eventů atd., a to až s dopadem na MDA a tedy i efektivnost marketingové komunikace $z$ hlediska klíčových indikátorů až po finanční ukazatele (stáhli si avizovanou novou VZ?, přihlásili se na výlet, kurz...?, zapsali žáka na kroužek?, aj.). ${ }^{134,135}$

\section{$?$}

\section{Jaká je motivace lidí pro komunikaci s využitím sociálních médií?}

Toto je velmi zajímavé a kličové téma. Pro komunity značek je důležité, aby byly atraktivní pro své uživatele. Výzkumy jsou založené na různých předpokladech a my si stručně ukážeme dva výchozí body pro některé z nich.

- Jedním z hlavních je tzv. teorie užití a uspokojení (Uses nad Gratification Theory = UGT), která zkoumá, jak a proč lidé použivaji média a stručně řečeno staví na tom, že máme potřebu získávat informace, bavit se, prezentovat se, komunikovat s ostatními atd. Vychází se z předpokladu, že lidé si účelově vybírají a použivaji média podle toho, aby aktivně dosáhli svých cílů a uspokojení výše uvedených potřeb.

- Dalším výchozím bodem jsou charakteristiky zákazníků. Například se vychází z osobnostních rysů (Big Five) a zkoumá se, jak tyto charakteristiky ovlivňuji užívání sociálních sítí a potom i vztah komunikace ke značkám na těchto sítích. Mutinga a kol. (2017) se zaměřili jen na tři znaky, které jsou orientované na ty, kteři jsou velmi dobře informováni (mavenism), ty, kteři se vyznačuji vysokým počtem přátel na síti a vysokou komunikaci (conectivity) a ty, kteři jsou v komunikaci přesvědčiví a ovlivňuji tak ostatní (persuasiveness).

Chování lidí je samozřejmě ovlivňováno mnoha faktory a není jednoduché jej v celé šiři zkoumat, nicméně existuje řada studií, které vycházejí např́iklad z UGT ${ }^{136}$ a prostřednictvím modelů hledají vztah zákazníků ke značkám v komunitách značek i na sociálních sítích.

\section{(ே)}

Všichni známe tvrzení, že každá mince má dvě strany.

\footnotetext{
${ }^{134}$ Nezapomeňte také na to, že rozdilná sdělení cili na rozdilné cilové skupiny a podle toho je i hodnotte.

${ }^{135}$ Ve firemním prostředí je již zavedená pozice „community manager“. Specializovaný operátor, který monitoruje a komentuje komentáře, zprávy a přispěvky uživatelů na konkrétním profilu sociální sítě... a pomáhá řešit problémy uživatelů a také bráni značku (Jindřǐšek \& Zvára, 2020).

${ }^{136}$ Následujíci přiklad vám pomůže spolu s copywritingem efektivně spravovat obsah na profilu sociální sítě.
} 
Komunikace na SM se někdy může stát dvousečnou zbraní. Firmy a někdy i školy se jí také obávají. Není jednoduchá zejména v krizové komunikaci (jedna z úloh Public Relations). Stránky mohou být také napadnuté hackery, ale na SM zejména tzv. hejtry, kteři mohou pomlouvat vaši školu, jeji aktivity atd.

Náš výzkum, ${ }^{137}$ který replikoval experiment komunikace na sociální síti z USA (Vandemia, 2017) a rozšiřil jej o sledování oční kamerou, jednoznačně potvrdil, že nesmírně důležité je včas a otevřeně reagovat na stižnosti. Tato komunikace je na profilech na SM velmi sledovaná i těmi, kteři jsou jinak v komunikaci pasivní. Dopad na image a značku školy je zřejmý.

Janouch (2020, s. 259-260) uvádí, že se ukazuje, že pro mnoho firem nemá smysl být na SM aktivní, i tak ale doporučuje sledovat komunikaci na nich ve vztahu k naší organizaci. Sdílená média (SM) podle něj nejsou všemocná, nemohou nahrazovat marketingovou strategii, nemohou být chápána jako krátkodobý projekt, nepřinášejí výsledky přiliš rychle, nemohou napravit špatnou reputaci a nemohou zaručit prodej či vliv.

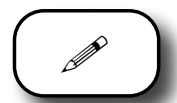

Dolan a kol. (2016) uvádějí, že v aplikaci UGT se často kombinuje následujicích pět součástí (kategorii): information, convenience, entertainment, self-expression, and social expression. Protože ale SM jsou zejména pro zástupce generací Z, Y i X uživatelsky pohodlná, je možné faktor (oblast) convenience vyloučit a potom pracovat s následujícím konstruktem, kde niže uvedené oblasti (dále také kategorie konstruktu) se vždy vztahuji k určitým potřebám uživatele.

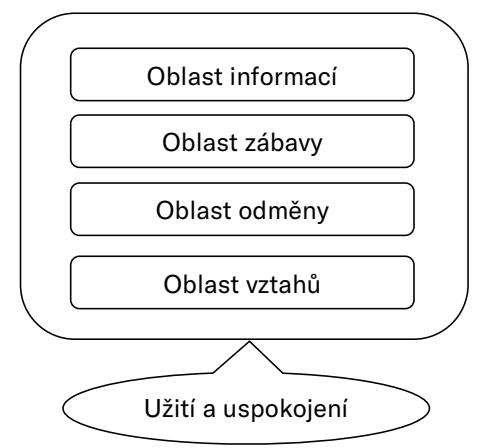

Obrázek 22: Konstrukt UGT pro sociální média dle Dolan a kol (2016)

\footnotetext{
${ }^{137}$ Eger, Komárková, \& Zákružná (2021), zaměřeno na vnímání personalizované komunikace zákazníky.
} 
Doručení vhodného obsahu, který bude naplňovat výše uvedené kategorie UGT uspokojí potřeby uživatele a bude jej motivovat k zapojení do komunity značky na SM. Dále stručně popíšeme jednotlivé kategorie s aplikací pro školy.

- Informační kategorie konstruktu UGT představuje míru, v niž obsah sociálních médií poskytuje uživatelům užitečné a v praxi potřebné (nápomocné) informace. Spojují to s touhou hledat informace prímo od zdroje, tj. školy o škole, o vzdělávání žáků, o aktivitách, úspěších školy, žáků i učitelů atd. ${ }^{138}$

- Kategorie zábavy v konstruktu UGT odkazuje na rozsah, v jakém je obsah SM médií zábavný a baví uživatele SM. Je to spojeno s potěšením uživatele, případně s estetickými nebo emočními požitky atd. Uvědomte si, že je to komunikace na sociální síti, kde pobavit (kulturně) a udržovat vztahy a komunikaci, je nezbytné!

- Kategorie spojená s odměňováním může být hybatelem pro vlastní spotřebitelské rozhodování (tedy o tom, zda zapíši žáka na vaši školu, do kroužku, zúčastní se...). Spotřebitel / klient chce získat nějakou výhodu a my ji musíme umět nabídnout i komunikovat.

- Kategorie spojená s interakcí. Potřeba integrace a sociální interakce spotřebitelů / klientů a jejich touha po sociálních výhodách byla identifikována jako klíčová motivace uživatelů k využiváni SM. Samož̌ejmě to souvisí s tolik potřebným navazováním a potom i udržováním dlouhodobých vztahů (Například, jak se vám daři pracovat s absolventy školy?).

Vychází se z poznání, že v kontextu SM uživatelé nejsou pasivní při výběru médií ani při použivání konkrétních médií. Vždyt samotná SM jsou konstruována tak, aby umožňovala interakci se zákazníky a dalšími uživateli a jejich zapojení.

\section{(:)}

Od roku 2019 jsme realizovali několik výzkumných šetření (např. Eger a kol. 2019) zaměřených na evaluaci komunikace vzdělávacích organizací na Facebooku. $V$ prvním prípadě se jednalo o studii zaměřenou na profily na Facebooku všech pedagogických fakult na Slovensku a v ČR. V druhém prípadě se jednalo o evaluaci profilů nejlepších univerzit ze zemí V4 na Facebooku (Eger a kol. 2020 a 2021). Mimo jiné se ukázalo, že:

\footnotetext{
${ }^{138}$ DiMartino a Jessen (2018) doporučuji, než jen na pouhé informování, zaměřit se na komunikování „prestiže“.
} 
- $\quad$ Aby instituce úspěšně budovaly vztahy s uživateli a dosáhly vysoké angažovanosti sledujících, musí být na profilu na Facebooku velmi aktivní.

- Neprokázal se vztah mezi engagementem a počtem studentů školy (velikost školy). To znamená, že některé menší subjekty dosahovaly lepších výsledků v komunikaci na Facebooku než velké instituce.

- Studenti (určitě i učitelé) mají zájem na aktivním vytváření obsahu na profilu své školy.

- Príspěvky ve formě foto a video dosahovaly největší odezvy od veřejnosti.

- Kvalitativní analýza potom prokázala, že príspěvky vztahující se obsahově $k$ zájmům cílové skupiny a s vhodnou výzvou $k$ akci, vedou opět k největšímu lajkování, sdílení a komentování (vezměte v úvahu teorii UGT).

- Administrátorům a manažerům se doporučuje, aby zvážili integraci sociálních médií do stávajících komunikačních nástrojů organizace s cílem podpořit image a značku školy.

- Zejména komunikace na stránkách SM se pro mladší generace žáků, rodičů, učitelů i dalších lidí z celé veřejnosti, včetně absolventů, stává významným bodem dotyku se školou.

Na závěr této kapitoly vám jako námět do diskuse vkládám následující sdělení:

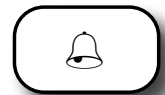

Podle Lockhart (2016b) je Facebook velmi efektivní nástroj pro zapojení komunity, která již má povědomí o škole. Facebook a př́padně jiné sociální sitě oproti www stránkám školy vedou k možnosti častěji informovat cílové skupiny a upozorňovat je na události, novinky a další zprávy. Komunikace by měla být více neformální, ale aktuální a je potřebné rychle reagovat na dotazy a prípadnou negativní zpětnou vazbu.

V publikaci k marketingu pro školy na s. 98 uváději DiMartino a Jessen (2018) odkaz na výzkum, který byl před lety uskutečněn v USA a byl zaměřený na efekt reklamy na prestiž instituce. Tvrdí, že „školy, které více investovaly do jejich webových stránek, promo videí a komunikace na sociálních sítích, byly považovány partnery, učiteli, studenty, ale i investory za školy s vyšší kvalitou." Je mi jasné, že ne všem pedagogům se to bude líbit, ale my jsme nyní $v$ oblasti disciplíny marketing školy, a tak to prosím mějme na paměti. 
(ن)

Marketingový tým

V návaznosti na již na zmíněný návrh vytvoření malého marketingového týmu ve škole, doplníme několik informací k SM. Lockhart (2016b) doporučuje vytvořit si na škole tým přispěvovatelů, kteří by odpovědně připravovali komunikaci na SM a editovali obsah pro zvolená SM. Tento tým nemusí jen sám vytvářet příspěvky, ale může také být odpovědný za získávání příspěvků od dalších členů komunity, jež je spojena se školou. Pokud tyto lidi rozdělíte i podle oblastí, kterým více rozumí, či jsou zde experty, získáte obsah více konzistentní a ve vyšši kvalitě.

\section{? Kontrolní otázky a úkoly:}

- Realizujte evaluaci webu vaši školy heuristickou metodou.

- Inspirujte se weby oceněných škol (schoolweb) nebo se podobně srovnejte $s$ nejbližši konkurencí.

- Podivejte se na statistiku přispěvků na profilu školy na sociální síti. Na které přispěvky jste obdrželi nejvyšší engagement?

- Kdo všechno může vytvářet obsah na webu školy a jejím profilu na $\mathrm{SM}$, kdo to koordinuje?

- Jak vypadá profil školy v Google a jak na Seznamu?

\section{[Dd Literatura:}

Eger, L. (2019). Aplikace teorie užití a uspokojení, sociální média a značky na sociálních sítích. Trendy v podnikání, 9(3), 19-25.

Janouch. V. (2020). Internetový marketing. Brno: Computer Press.

Světlík, J. a kol. (2016). Marketingové komunikace. Praha: VŠPP Praha. 


\section{MARKETINGOVÝ VÝZKUM A ŠKOLA}

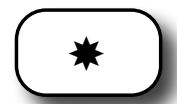

Cíle:

- Upozornit na důležitost marketingového výzkumu pro rozhodování managementu.

- Objasnit možné zaměření marketingového výzkumu realizovaného školou.

- Připomenout si základní postup pro realizaci výzkumu.

- Získat náměty pro realizaci dotazování ve škole.

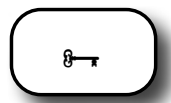

\section{Klíčová slova:}

marketingový výzkum, dotazování, dotazník, interview, focus groups

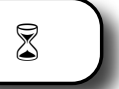

Čas potřebný ke studiu základního textu kapitoly je cca 15 minut + možnost rozšírení o studium externích zdrojů $\mathrm{z}$ internetu.

\section{Úvod}

Umím si představit, že někteři vedoucí pracovníci si u této kapitoly řeknou, „tak na to skutečně již nemáme čas“ nebo „to není náš úkol“. Ano, ředitelé našich škol jsou skutečně velmi vytižení a velmi zaneprázdnění poměrně rozsáhlou administrativou, jak prokázaly i průzkumy ČŠl. Nicméně zvažte následujíci základní tvrzení:

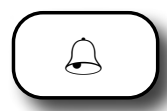

Marketingový výzkum školy zahrnuje aktivity, které poskytuji vedoucím 
pracovníkům škol informace, ${ }^{139}$ jež potřebuji, aby byli schopni realizovat rozhodování na základě relevantních informaci. Právě produktivní výzkum, či průzkumy realizované přímo školou, přinášejí informace potřebné pro lepší či správnější rozhodování (srovnej s Lockhart, 2016a, s. 45-47). ${ }^{140}$

\section{(2)}

Ze stejného zdroje (Lockhart, 2016a) zmíníme, proč vedoucí pracovníci jsou spiše skeptičtí k této součásti marketingu školy. Marketingový výzkum je jimi považován za něco, co je komplikované, drahé a stojí mnoho času. Někteří jej dokonce považuji za nepotřebný, protože oni dobře cití, co je potřebné udělat a přeci dobře znají, co si interní i externí skupiny veřejnosti o škole myslí a jak o ní komunikují. Někteři se dokonce obávají toho, že možná negativní zjištění hned negativně ovlivní publicitu školy. A nejhorším důvodem je, že to může vést $k$ požadavku řešit problém, kterému se oni chtějí vyhnout. Ano, skutečně může dojít $k$ tomu, že když realizujete výzkumné šetření zaměřené na komunity spojené se školou, její zaměstnance nebo studenty, data mohou ukázat i překvapivé a neočekávané výstupy.

\subsection{Zaměření marketingového výzkumu školy}

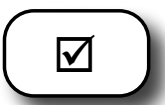

Marketingový výzkum může být zaměřen na širokou škálu problémů. Můžeme je také strukturovat podle základních marketingových „P“. Navíc nás bude velmi zajímat chování relevantních cílových skupin ve vztahu ke vzdělávání a k naši škole, do hloubky nám půjde o pochopení jejích postojů, chování, konzumace médií a poznání jejich životního stylu. ${ }^{141}$

Pojd'me se nyní v aplikaci podívat na možné zaměření právě podle základních „P“.

- Produkt (vzdělávací služba). Aktivity spojené s aplikací marketingového výzkumu jistě využijeme při prípravě nového vzdělávacího programu či doplňkových služeb školy. Budeme zjištovat informace pro

\footnotetext{
$\overline{{ }^{3} 9}$ Ostatně potřebu informací pro rozhodování ředitelů škol prokázalo i šetření mezi řediteli škol v ČR (např. Voda, 2015).

${ }^{140}$ Školy se dnes také účastní řady projektů, včetně mezinárodnich, poznatky k realizaci průzkumu... se hodi.

${ }^{141}$ Viz i Hair a kol. (2021, s. 7.). Naopak školy nebudou zřejmě usilovat i o rozvoj teorie, k čemuž také marketingový výzkum slouži.
} 
jeho efektivní uvedení do praxe a komunikování, vše kolem brandingu a samozřejmě potřebujeme data a informace k positioningu. Jak jsme již uvedli $v$ předešlých kapitolách publikace, trendem $v$ marketingu škol je branding a my potřebujeme znát názory cílových skupin a jejich očekávání ve vztahu ke škole a jejímu vzdělávacímu programu. Pro školy v konkurenčním prostředí to potom znamená skutečně zjištovat, jaká kritéria použivaji zástupci našich cílových skupin, když porovnávají školy a jejich programy (patři sem např. i vytváření percepčni mapy).

- Místo (distribuce). Zde se určitě zaměříme na evaluaci místa naší školy v regionu, případně na hodnocení kanálů (zde vzdělávacích cest), kterými poskytujeme vzdělávací služby, ale můžeme zde hodnotit i naše distribuční partnery. Ve firemní oblasti sem patří oblast prodeje (retailing). Jak u vás hodnotíte kontaktní aktivity s potenciálními či současnými zákazníky z hlediska distribuce? ${ }^{142}$

- Cena. V této oblasti se, asi kromě soukromých škol, budeme hodně odlišovat od firemni sféry. Nicméně, i my musíme zvažovat to, jak naši klienti vnímaji celkové náklady vůči hodnotě, kterou jim poskytujeme. Určitě je také vhodné sledovat kontext a trendy, které mohou ovlivnit školu z vnějšího prostředí (otázka poplatků, přispěvků na..., př́ípadně až výše školného). Nezapomeňte, že z pohledu marketingu se neplatí jen penězi.

- Marketingová komunikace. Rozhodnutí o komunikaci školy s veřejností může významně ovlivnit to, zda budete mít dostatek žáků či studentů, zda si potom tito vyberou i dalši služby, jež poskytujete (kroužky, exkurze, doučování...). U placené části komunikace nás zajímaji data, která nám umožní rozhodnout, jak vynaložené prostředky na propagaci co nejefektivněji využijeme. Potřebujeme $k$ tomu používat a sledovat i vhodné metriky (viz i marketing na internetu). Z pohledu integrované marketingové komunikace můžeme chtít realizovat průzkumy ve vztahu k již uvedeným reklamnim aktivitám, opět výzkum zaměřený na očekávání cílových skupin a značku a mapovaní toho, jak uskutečňujeme „prodej“.143

- Lidé (people). Tuto oblast necháme pedagogickému výzkumu v zaměření na vzdělávací proces, i když je evidentní, že to souvisí s poskytováním vzdělávacích služeb, a tedy i s marketingem školy. Nicméně, zde připomeneme, že sem řadíme problematiku cílení na relevantní skupiny zákazníků (segmentování). Potřebujeme tedy získávat data o našich zákaznících, trhu, ale i konkurenci.

\footnotetext{
${ }^{142}$ I my můžeme posuzovat cestu našeho „zákazníka“ (kdy, kde a jak se rozhodne o zapsáni žáka na školu?).

${ }^{143}$ Opět je velký rozdil mezi veřejnou službou a institucí bez konkurence v regionu a školami v konkurenčním prostředí či soukromým subjektem, který chce prorazit na trhu.
} 


\subsection{Realizace výzkumu}

Není naším cílem v předložené publikaci se podrobně zabývat problematikou metodologie výzkumu (Eger, \& Egerová, 2017; Creswell, 2014). Zájemce odkážeme na například dostupnou publikaci Hendl a Remr (2017), která specificky obsahuje i část zaměřenou na evaluaci. Samozřejmě pro pedagogický výzkum existuje řada publikací, např. Gavora (2010) nebo Chráska (2016). Pro marketingový výzkum Ize např́klad odkázat na publikace Tahal a kol. (2017) nebo Burns a kol. (2017).

\section{$\square$}

Plán výzkumu nebo také design výzkumu zahrnuje několik základních a klíčových rozhodnutí, které je nutné přijmout v pořadí tak, jak mají význam pro přípravu vlastního výzkumu.

Jedná se o strategické rozhodnutí o našem přistupu $k$ řešení výzkumného úkolu a od něho se odvijí i další rozhodnutí, jež jsou zaměřená na použití specifických metod, ale i analýzu dat a jejich interpretaci. Dále si představíme základní doporučený postup při realizaci výzkumu, který je vhodné obecně použivat.

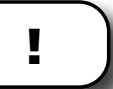

\section{Identifikace a objasnění informačních potřeb}

Obvykle ten, kdo potřebuje data pro rozhodování, připraví vstupní prohlášení $s$ popisem problému, který je potřebné řešit. Potom dochází k upřesnění zadání. Je potřebné jasně popsat (pojmenovat) potřebu realizace výzkumu, pochopit kontext prostřednictvím situační analýzy. Zde nám může posloužit i aplikace SWOT analýzy, kterou již znáte.

Potom následuje vymezení jednotky pro analýzu v plánované studii či výzkumu a za pomoci desk research a tedy práce se sekundárními daty dále konkretizujeme problematiku a hledáme i proměnné a jejich znaky, které budeme ve výzkumu zjištovat. Zde dochází k rozdílu ve výzkumu s kvantitativním přístupem, kde vycházíme z dosavadní teorie a jsme schopni aplikovat relevantní metody a aplikovat či vytvořit nástroje pro sběr dat, a ve výzkumu s kvalitativním přistupem, kde zjištujeme, že jev je nový nebo částečně nepopsaný, teorie není úplná atd. 


\section{$?$ Položte si vždy následující otázky:}

- Je navrhovaný výzkum realizovatelný?

- Je potřebné a účelné výzkum realizovat?

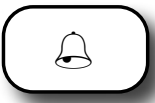

Zvažte:

Smyslem kvantitativního výzkumu je přinést odpověd' na otázku kolik? Výstupem jsou grafy, tabulky, které přinášejí informace o zastoupení sledovaného jevu nebo názoru v cílové populaci ... Kvantitativní výzkum se používá i pro testování hypotéz.

Kvalitativní výzkum přináší odpovědi na otázku proč? Kvalitativní výzkum je zaměřen na objasnění a vysvětlení sociálních jevů z pohledu jedinců či skupin. Výzkumník vytváŕi jejich interpretaci a objasňuje význam získaných výstupů.

\section{Vytvoření výzkumných otázek.}

Je to kličový bod. Vstupně popsaný výzkumný problém nyní musíme převést do výzkumných otázek. ${ }^{144}$ Opět vycházíme ze zkušeností získaných z přehledu literatury $\mathrm{k}$ problematice. Tento krok ovlivní další postup. Pokud použijeme obecnou výzkumnou otázku, musíme ji dále specifikovat. Specifické výzkumné otázky by měly ukazovat na data (sekundární a primární), která potřebujeme získat $k$ jejich zodpovězení.

\section{Zvažte:}

- Propojení specifické výzkumné otázky a potřeby získání dat pro nalezení odpovědi je vlastně podstatou výzkumu.

- Výzkumné otázky v kvantitativním designu obvykle obsahuji vztahy mezi proměnnými (a v návaznosti na ně navazuji hypotézy). ${ }^{145}$

- I v kvalitativním výzkumu by specifické výzkumné otázky měly být jasně formulované. Bývaji otevřenější a je možné, že dojde $k$ jejich přehodnocení v průběhu výzkumu po získání první zkušenosti atd.

Doporučujeme nejdřive se soustředit na návrh výzkumných otázek a až následně na metody použité v plánovaném výzkumu.

\footnotetext{
${ }^{144}$ Ve starším designu výzkumu se použivaji cíle a dílči cíle.

${ }^{145} \mathrm{U}$ kvantitativního výzkumu se také často z teorie přimo odvozuji hypotézy.
} 


\section{Rozhodnutí o výzkumu.}

Nyní musíme rozhodnout o vhodném designu výzkumu, který bude odpovídat stanoveným otázkám nebo cílům výzkumu. Design výzkumu je plán, jak použijeme metody výzkumu a jak budeme analyzovat data. Jsou zde tři základní kategorie designu výzkumu: exploratorní, deskriptivní a explanační. Kromě kvantitativně nebo kvalitativně zaměřeného výzkumu může dojít ke kombinaci metod ve strategii smíšeného výzkumu (Creswell, 2014).

- Kvantitativní výzkum vychází z dosavadní teorie, použivá hypotézy, staví na náhodném výběru, experimentech a strukturovaném sběru dat prostřednictvím testů, dotazníků či pozorování.

- Kvalitativní výzkum zkoumá určitý prvek, proces, fenomén apod. $v$ jeho přirozených podmínkách. $V$ kvalitativním výzkumu se mu snažíme porozumět a vytvořit i s interpretací dat pokud možno komplexní obraz zkoumaného jevu.

- Smíšený výzkum představuje přístup, kdy výzkumník chce rozšírit či zlepšit výstupy výzkumu tím, že při použití jedné metody ve výzkumu navazuje použitím jiné metody z odlišného základního designu výzkumu.

V prvním a druhém kroku plánování výzkumu jsme si definovali základní pojmy a ty v kvantitativním výzkumu musíme operacionalizací převést na zkoumatelné ukazatele, jež si presně vymezíme. Proměnné zjištuje pomocí znaků (vyjadřuji vlastnost jevu), které můžeme zjistit, třídit, měřit a jež musí být zejména v kvantitativním výzkumu rozlišitelné, úplné a jednoznačné.

V kvalitativním výzkumu také na základě sekundárních zdrojů specifikujeme téma, ale obvykle zjistíme, že téma je nové nebo ne zcela popsané či ukotvené v teorii. Nelze jednoznačně operacionalizovat proměnné. Operujeme $v$ prirozeném prostředí a sběr dat, potom analýza a jejich interpretace jsou zejména založené na sledování toho, co lidé dělaji a říkají. $K$ dalšímu zpřesňování výzkumu může docházet až v jeho průběhu.

U smíšeného výzkumu se může jednat například o vstupní kvalitativní šetření prostřednictvím otevřených rozhovorů z důvodu objasnění nějakého jevu a následuje kvantitativní výzkum s velkým souborem respondentů, který má potvrdit nebo vyvrátit výsledky z první fáze a může vést ke generalizaci získaných poznatků.

Podobně výzkum může začít kvantitativním šetřením u velkého souboru respondentů a $v$ následující kvalitativní části je využita metoda kvalitativního výzkumu pro hlubši pochopení problematiky. ${ }^{146}$

\footnotetext{
${ }^{146}$ Strategie současného smišeného výzkumu použivá procedury, kdy výzkumník současně sbirá kvalitativni i kvantitativní data, aby dosáhl, co nejkomplexnějšího a nejobjektivnějšiho pohledu na realitu či zkoumaný jev.
} 


\section{Rozhodnutí o výzkumném souboru.}

Zejména pokud realizujeme výzkum empirický, musíme věnovat pozornost výzkumnému souboru. Tady to nebude jednoduché rozhodování. Škola zřejmě nebude dělat výzkum, který by byl zaměřen na velké soubory či dokonce census a výběr zkoumaných jednotek dle pravděpodobnosti. I tak si výzkumník musí být vědom toho, co všechno nebo kdo všechno tvoři základní soubor, a jak zvolí výběrový soubor. $V$ praxi se často bude jednat o cílené zaměření na určité cílové skupiny, záměrné a dostupné výběry či výběr s využitím kvót. Samožrejmě, u malého souboru respondentů, se můžeme dotázat i všech členů souboru (všichni učitelé či žáci školy). Pozor, výstupy těchto spíše průzkumů jsou pro školu důležité, ale závěry nemůžeme generalizovat napřiklad na celou populaci učitelů či žáků v ČR. ${ }^{147}$

- Vzorek respondentů v kvantitativním výzkumu by měl reprezentovat populaci jedinců.

- V kvalitativním výzkumu vybíráme respondenta jako jedince, který reprezentuje názory skupiny, často při výběru používáme techniku nabalování (snowball technika). Cílem je reprezentovat populaci nebo problém.

\section{Aplikace výzkumných metod a výzkumných nástrojů.}

$V$ designu výzkumu jsme si již zvolili jeho zaměření a i metody, kterými výzkum budeme realizovat. Nyní je potřebné, a to opět i s využitím výstupů z desk research, sestavit postupy pro aplikace zvolených metod a převzít, upravit ${ }^{148}$ nebo i vytvořit výzkumné nástroje. Tedy napřiklad dotazníky pro dotazování, scénáře pro hloubkové rozhovory či focus groups nebo nástroje pro záznam pozorování apod. Ten, kdo realizuje výzkum, by měl metody znát a pečlivě volit nástroje a připravit postupy pro administraci výzkumu a sběr dat.

Rozhodně je doporučeno realizovat pretest či předvýzkum (se zástupci cílové skupiny a připadně i tazateli atd.), kde prověřite, zda je váš plán skutečně realizovatelný a můžete minimalizovat možné chyby. Také si upřesníte požadavky na zdroje pro realizaci celého výzkumu (finanční, lidské, materiální, časové).

\section{Sběr dat a příprava dat pro analýzu.}

V našem prípadě často budeme mít k dispozici tzv. „big data“, které již škola má, či je pravidelně sbírá a někdy i reportuje. Patři sem pedagogická dokumentace, účetnictví, webová analytika atd. Nebo je budeme sbírat především prostřednictvím dotazování (rozhovory, focus groups, dotazníky...) a pozorování (záznamy chování..., analýza www stránek škol a komunikace na sociální síti...).

\footnotetext{
${ }^{147}$ Soubor, viz např. Hendl a Remr (2017).

${ }^{148}$ Zejména u vytvořených či upravených nástrojů je vhodné realizovat i jejich pilotáž.
} 
Je velký rozdíl mezi tím, když sbíráme kvalitativní a kvantitativní data a samožrejmě to má dopad na jejich záznam, verifikaci, utřídění (někdy vyčištění) a připravu pro následnou analýzu.

\section{Analýza dat.}

Protože se jedná o výzkum na úrovni školy, nebudeme uvažovat u kvantitativních dat jejich zpracování sofistikovaným statistickým software, ale napřiklad program Excel nám dnes nabízí dostatek vhodných nástrojů pro analýzu a prezentaci dat. Určitě nejdřive použijeme deskriptivní statistiku a mnoho odpovědí najdeme díky tzv. druhému třídění dat a například využití kontingenčních tabulek apod.

U kvalitativních dat je situace složitější, některá lze vhodně převést na nominální a ty pomocí četností popsat, ale jinak jde o slova a jejich významy, a ne o čisla. Interpretovat výstupy je potřebné zodpovědně. Vhodné je kličová tvrzení dokumentovat přiklady vět = sdělení respondentů (př́ípadně s poznámkou tazatele) atd.

\section{Příprava závěrečné zprávy a její prezentace.}

Znalost pro toho, kdo má rozhodovat, se vytváŕi na základě získaných dat, kterým se dává význam, tj. vytváŕi se informace a ta při aplikaci do praxe se teprve stává znalostí. Interpretace výstupů z výzkumu je více, než jen základní deskripce. Aspekty a výstupy výzkumu, včetně opět diskuse s dřive získanými znalostmi ze sekundárních dat, přetváríme v závěry, které by měly odpovídat na položené výzkumné otázky.

Reportování dat je také důležité. Dnes je vyžadovaná relevantní vizualizace výstupů a závěrů. Pokud je výzkumná zpráva rozsáhlejší, je doporučeno připravit i tzv. executive summary, tj. strukturovaný a přehledný souhrn o celém výzkumu stručně na 2-3 strany.

U významnějšího výzkumu nezapomeneme zmínit i omezení výzkumu a připadně návrh na další následné směřování výzkumu.

\subsection{Dotazování}

Není úkolem předložené publikace podrobně popsat metody dotazování a jejich nástroje atd. Stručně si uvedeme základní informace k dotazování $s$ využitím dotazníku a dotazování s využitím metody focus groups. Obojí jistě najde uplatnění v praxi pro marketing školy. ${ }^{149}$

\footnotetext{
${ }^{149} \mathrm{Z}$ pedagogického hlediska odkazujeme napřiklad na publikaci Gavora (2010), z hlediska marketingu napřiklad na publikaci Foret a Stávková (2003).
} 


\subsection{Dotazník}

$\square$

„Dotazníky jsou různého typu. Jde o formulár̆, který vyplňuje obvykle sám respondent (př́padně $v$ interakci $s$ tazatelem či programem na internetu). Výzkumníci používají dotazník, aby získali informace o myšlenkách, pocitech, postojích a hodnotách zkoumaných osob“" (Hendl \& Remr, 2017, s. 82)..$^{150}$ Samotný dotazník je zpravidla konstruován jako soubor předem připravených otázek, na které respondent (dotazovaná osoba) odpovídá a kromě zjištování znalostí, názorů, postojů, preferencí, motivace, citových stavů, zjištujeme i osobní a demografické charakteristiky respondentů.

Dotazník je využíván zejména k získávání dat hromadné povahy. Znamená to, že prostřednictvím dotazníku můžeme získat údaje od velkého souboru respondentů, a to při relativně malé časové investici.

Zvažte:

Jako výzkumný nástroj je dotazník v různé míře aplikován jak v kvalitativních, tak i především v kvantitativních výzkumných přístupech. V kvalitativních prístupech nebývá dotazník jediným způsobem (nástrojem pro) zkoumání a je zpravidla využíván jako doplněk $k$ dalším technikám či metodám, například jako doplněk k rozhovorům a pozorování.

V rámci kvalitativních přístupů jsou nejčastěji použivány dotazníky obsahující zejména otevřené (volné) otázky. Obecně můžeme říci, že použití dotazníku není vhodné ve výzkumech, které vyžaduji použití převážně otevřených otázek.

V kvantitativních přistupech naopak bývá dotazník aplikován jako hlavní výzkumný nástroj. Jedná se převážně o využití standardizovaného dotazníku (byl vytvořen na základě teorie a je již prověřen...), který obsahuje soubor zejména uzavřených otázek stejných pro všechny respondenty. Ačkoliv může být dotazník použit jako jediná technika sběru dat, je vhodnější jej použít v kombinaci s jinými metodami (viz problematika smíšeného výzkumu).

\footnotetext{
${ }^{150}$ Alternativně uvedeme dle Gray (2009, s. 337): „Dotazníky jsou výzkumné nástroje, prostřednictvím kterých jsou lidé požádáni o odpovědi na předem připravený a stejný soubor otázek.“
} 


\section{!}

Výzkum s využitím dotazníku zjištující postoje respondentů je vhodné doplnit hloubkovými rozhovory s několika respondenty z cílové skupiny nebo focus groups, které se zaměřuji na zjištění a pochopení těchto postojů.

\section{Typologie dotazníků}

Dotazníky Ize členit z různých hledisek. Nejčastěji členíme dotazníky podle cile výzkumu a strukturace položek v dotazníku na:

- Nestrukturovaný dotazník - je vymezeno pouze určité téma, ke kterému se respondent volně písemně vyjadřuje, výhodou této varianty dotazníku je přehlednějši písemné zpracování ve srovnání s ústním vyjádřením, nevýhodou je naopak časová náročnost pro respondenta a náročnější zpracování odpovědí pro výzkumníka.

- Polostrukturovaný dotazník - obsahuje soubor otázek, na které respondent ve volném pořadí odpovídá, využívány jsou uzavřené i otevřené otázky. Výhody a nevýhody jsou obdobné jako u nestrukturovaného dotazníku.

- Strukturovaný dotazník - obsahuje soubor otázek, které jsou uspořádány v pevně daném pořadí. Použivá převážně uzavřené otázky. Výhodou je srovnatelnost odpovědí respondentů a snadnost zpracování dat. Nevýhodou je naopak menši vypovídací hodnota vzhledem $\mathrm{k}$ tomu, že odpovědi respondenta jsou získávány pouze z nabízených variant.

Z hlediska typologie dotazniků je potřebné také ujasnit pojmy standardizovaný vs. nestandardizovaný dotazník. $V$ připadě standardizovaného dotazníku se jedná o dotazníky, jejichž validita a spolehlivost je známá, byla ověřena již předešlými výzkumy. Standardizované dotazníky umožňuji porovnávat výsledky různých autorů. Naopak za nestandardizované dotazníky považujeme dotazníky vlastní konstrukce aplikované v rámci jednoho výzkumu nebo ve specifické anketě školy apod. ${ }^{151}$

\footnotetext{
${ }^{151}$ Pod pojmem standardizovaný dotazník je mnohdy v literatuře chápán dotazník, který je pro všechny respondenty stejný a který obsahuje soubor převážně uzavřených otázek uspořádaných v jasně daném pořadí. Toto chápání se terminologicky bliži pojmu strukturovaný dotazník. Standardizovaný dotazník musí splňovat jasná kritéria kvality (a být standardizován = uznán).

Anketa je nástrojem, který je často využiván $\mathrm{k}$ dotazováni. Je velmi oblíbeným nástrojem pro různé dilcči průzkumy právě i v oblasti školstvi (obvykle jen několik položek na určité téma). Bohužel výstupy anket jsou často zobecňovány na populaci, což je chybné.
} 
Zvažte:

Při přípravě dotazníku doporučujeme zvážit, zda při řešení daného výzkumného problému použijeme standardizovaný dotazník nebo vytvoříme vlastní dotazník. Pokud nemá výzkumník dostatečné zkušenosti s metodologii tvorby dotazníku, je vhodnější použít již existující dotazníky, zde ale musíme dát pozor na autorská práva a prípadně také modifikovat dotazník na místní podmínky.

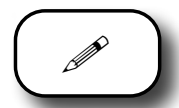

V přiloze publikace najdete dotazníky ke kultuře školy a $\mathrm{k}$ image školy, které již byly prověreny (viz i publikování výstupů ve vědeckých časopisech). Podobně, napřiklad pro téma klima školy či třidy, najdete zdroje napríklad pod NUOV zde:

http://www.nuov.cz/uploads/AE/evaluacni_nastroje/14_Klima_skoly.pdf

NPI Praha na svých stránkách k projektu Strategické řizení ve školách také nabízi celou řadu vhodných a prověřených dotazníků $\mathrm{k}$ tématu:

https://vedemeskolu.npi.cz/strategicke-rizeni-ve-skolach/

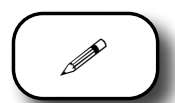

Nebudeme se zde podrobně věnovat položkám dotazníku, ale uvedeme, jak je potřebné $\mathrm{k}$ jejich vytváření přistupovat (tedy pokud se rozhodnete si například udělat svoji anketu).

Klíčovou podmínkou účelného návrhu dotazníku je ujasnění si toho, co chceme dotazníkem zjistit (cíl a účel) a jaká data potřebujeme získat, abychom mohli odpovědět na specifickou výzkumnou otázku (otázky). Znalost cíle a účelu dotazníku napomáhá k vyjasnění si jeho obsahového zaměření i k obsahovému zaměření jednotlivých položek dotazníku, viz obrázek 23. 


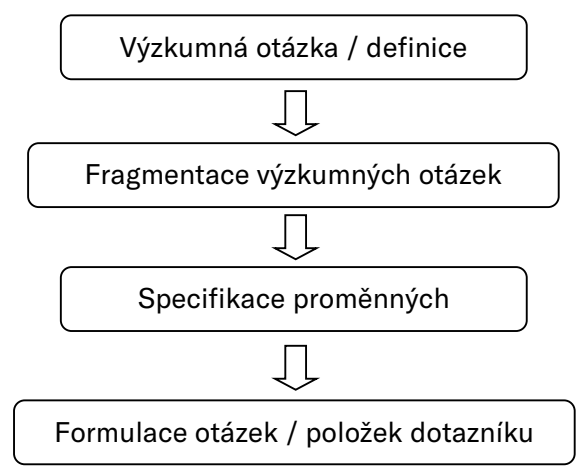

Obrázek 23: Schematické zobrazení návrhu dotazníku

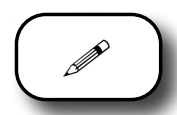

- Výzkumná otázka - tvoři koncepční rámec pro sestavení dotazníku, je potřebné vymezit, zda hlavni výstup výzkumu je deskriptivní, explorativní nebo explanační.

- Fragmentace výzkumné otázky - rozdělení otázky do menších specifických otázek.

- Specifikace proměnných ${ }^{152}$ - identifikace proměnných, ke kterým budeme sbírat data potřebná k zodpovězení definovaných otázek. Specifikace proměnných ovlivňuje způsob formulace položek dotazníku. U každé proměnné si ujasníme, zda data budou mít kognitivní (znalosti), afektivní (postoje), behaviorální (chování) nebo faktické (demografie) charakteristiky.

- Formulace otázek/položek dotazníku - jsou základním stavebním kamenem každého dotazníku (opět odkazujeme na doporučenou literaturu).

\section{Struktura dotazníku}

Design dotazníku je systematický proces, ve kterém výzkumník zvažuje použití různých formátů otázek (položek dotazníku), jež jsou voleny na základě

\footnotetext{
${ }_{152} Z$ hlediska kauzální závislosti rozdělujeme proměnné na nezávisle proměnné (např. pohlaví, věk, stupeň vzděláni) - působi na jinou závislou proměnnou, je stabilnějši, neměni se v průběhu výzkumu a závisle proměnné (např. spokojenost, názor, postoj, volba stylu vedení,) - ty jsou často ovlivňovány dalšimi proměnnými, mění se v průběhu výzkumu. Některé proměnné můžeme měřit jednou položkou (otázkou dotazujici se na znak), jiné mohou být měřeny více položkami, sadou zjištovaných znaků.
} 
kontsrutu dotazníku, upravovány z hlediska jazykového a celkového layoutu (struktury a rozložení součástí) dotazníku a nakonec i na základě pilotáže a předvýzkumu.

Při přípravě dotazníku je důležité věnovat pozornost uspořádání položek dotazníku a jeho celkové struktuře. Dotazník by měl mít logickou, jasnou a promyšlenou strukturu. Strukturu dotazníku zpravidla tvoři:

- Vstupní část/úvodní část. Ta obsahuje úvodní oslovení respondenta, sdělení o účelu výzkumu, vysvětlení významu dotazování. Tato část obsahuje také pokyny, jak dotazník vyplňovat ( $k$ pokynům je někdy vhodné uvést ilustrativní př́klad) a žádost o vyplnění dotazníku. Účelem úvodní části je motivovat respondenta k vyplnění dotazníku a přesvědčit ho o důležitosti správného vyplnění. Tato část je důležitá zejména pokud se jedná o administrovaný dotazník, tj. vyplňovaný bez přitomnosti tazatele.

- Druhá část - obsahuje vlastní otázky/položky. Na začátku bývají zpravidla úvodní otázky, které navazují kontakt s respondentem a otázky které jsou pro respondenta zajímavé, neproblémové a přitažlivější. Měly by motivovat respondenty a získat jejich zájem o vyplnění dotazníku. Následuji otázky věcné, obtižnějši a mnohdy pro výzkum kličové. Doporučuje se položky uspořádat do tematických bloků. Při přechodu $k$ dalšímu tématu je vhodné upozornit na změnu. Na změnu je potřebné upozornit i při změně formátu dotazování např. přecházíme-li z otázek na tvrzení. Na konci dotazníku jsou zařazeny identifikačni položky, které mohou být citlivé povahy nebo prípadně položky, které se ne zcela vztahuji k tématu výzkumu, ale pro výzkumníka jsou důležité.

- Závěrečná část/konec dotazníku. Ta obsahuje poděkování respondentovi za spolupráci, připadně poskytnutí kontaktu, datum do kdy by měl respondent dotazník odeslat.

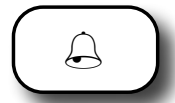

Zvažte:

Velkým problémem je v současné době návratnost dotazníků ve všech formách. Proto pečlivě zvažte účelnost dotazování, motivaci respondentů, rozsah dotazníku a skutečné využití každé jeho položky. Každý dobrý dotazník má také jasně stanovený cíl. 


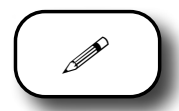

Dále uvádíme obecná doporučení pro design dotazníku dle Burns a kol. (2017):

- Otázky by měly být jasné, jednoduché, specifické a relevantní ve vztahu k zaměření výzkumu, jak jen je to možné.

- Otázky by měly být zaměřené zejména na současné postoje a chování respondentů.

- Obecnější otázky by měly předcházet specifičtějším.

- Nepoužívejte vágní a nejednoznačná slova. Pozorně realizujte pre-test předvýzkumem.

- Pro Likertovy škály je doporučeno používat od 5 do 8 možných položek pro odpovědi.

- Nepouživejte neutrální nebo žádnou střední možnost odpovědi, zvyšuje to validitu a reliabilitu.

- Všechny číselné možnosti by měly být $k$ dispozici respondentům pro jejich odpověd'.

- Nesouhlasím“ by mělo mít nízké číslo, proti možnosti odpovědi „souhlasím“.

- Použijte možnost „Nevím“, pokud by se respondent mohl obávat, že problematiku nezná, má nedostatek informací nebo by se mohl zdráhat odpovědět.

- Položky zaměřené na zjištování demografických údajů by měly být na konci dotazníku.

\subsection{Interview a focus groups}

\section{$\sqrt{ }$}

Interview je výzkumnou metodou, která patři do dotazování, jež obecně zahrnuje sběr dat prostřednictvím dotazníků, různých typů rozhovorů, ale i prostřednictvím škál a testů (viz i Hendl, 2008).

Interview je přitom výzkumnou metodou, která výzkumníkovi umožňuje zachytit nejenom data, ale i hlouběji proniknout do motivů a postojů respondentů. Zejména při osobním rozhovoru můžeme sledovat také reakce respondenta a podle nich potom usměrňovat další průběh rozhovoru s ním.

Slovo interview můžeme rozdělit na „inter“, což znamená „mezi“ a „view“, které znamená „názor“ nebo „pohled“. Již z názvu tedy vyplývá, že se jedná 
o aktivitu spojenou s interpersonálním kontaktem výzkumníka s dotazovaným. Přitom dnes vedení výzkumného rozhovoru může být spojeno nejenom se setkáním se přímo (F2F), ale i s využitím ICT, například telefonické dotazování, video-hovor (Skype, Teams, Google Meet aj.). ${ }^{153}$

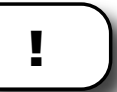

Vedení rozhovoru a „nasloucháni“ zástupcům našich cílových skupin je mnohokrát zmíněno v publikaci k marketingu školy (Lockhart, 2016a) jako jedna ze základních cest, jak poznávat potřeby a prání těchto skupin a získávat zpětnou vazbu $\mathrm{k}$ naši marketingové komunikaci. ${ }^{154}$

Hendl (2008) uvádí, že existují dvě krajní formy dotazování prostřednictvím rozhovoru:

- Interview s pevně danou strukturou otázek a s uzavřenými otázkami, kde je evidentní, že výstupy můžeme zpracovávat i kvantitativně (a z tohoto důvodu je tato forma použivána).

- Interview, kde struktura není předem dána a forma se $v$ praxi přibližuje vyprávění respondenta. Tzv. nestrukturované interview umožňuje úplnou volnost odpovědí a tím může přinést i nové a často i nepředpokládané informace, jež nám pomáhaji pochopit zkoumané téma více do hloubky (zejména exploratorní účely).

Třetí formou je polostrukturované interview, kde v praxi můžeme najít varianty, jež se bliží uvedené první formě a interview obsahuje i polouzavřené otázky a několik otevřených otázek. ${ }^{155}$ Opačně uvedeme, že existují varianty polostrukturovaných interview, kde jsou převažující otevřené dotazy a potom je napřiklad použito několik uzavřených otázek s výčtem odpovědí, škálou atd.

\section{!}

Výběr formy interview zcela logicky závisí na zvolené strategii a designu výzkumu.

\footnotetext{
${ }^{153}$ Uvádi se také vedení interview s využitím internetu a opět je možné zvažovat individuální i skupinovou formu. Také se použivá pojem oline dotazování.

${ }^{154}$ Při využití ve výzkumu se obvykle realizuje $4-5$ skupin a akce se ukonči při tzv. saturaci dat, tj. v dalšich skupinách již prakticky nezískáváme od cílové skupiny nové informace.

${ }^{155}$ Otevřené otázky použijeme napřiklad pro exploratorni účel.
} 
U interview je velmi důležité úspěšné navození kontaktu a vytvoření „důvěrné atmosféry“", jež umožňuje získat validní data. Tomu obvykle můžeme pomoci představením se a stručným sdělením účelu rozhovoru. ${ }^{156}$

Jestliže se tazateli nepodaři navázat vhodný kontakt s respondentem (informantem), můžeme získat data zkreslená a v krajním případě respondent odmítne rozhovor a spolupráci s výzkumníkem. Jistě z praxe znáte, jak je někdy složité vést otevřený rozhovor s některými žáky a jejich rodiči.

Obsahem interview jsou předem připravené otázky, kdy u strukturovaného interview tato príprava má v podstatě formu dotazníku, který při rozhovoru $s$ respondentem vyplňujeme. $V$ opačném případě máme připraveno jen několik otevřených otázek či různě volnou či jen základně strukturovanou formu itineráře pro vedení rozhovoru.

Strukturovaná forma také obvykle znamená, že dotazování může probihat rychleji, u druhé formy je čas interview naopak stanoven spiše orientačně a jeho potřebu nám (mimo jiné) dobře ukáže předvýzkum.

U polostrukturovaného a zejména u nestrukturovaného interview může výzkumník dle potřeby i přeformulovat otázky v průběhu vedení rozhovoru. $\mathrm{Na}$ jedné straně tak může požádat o doplnění informace, ale na straně druhé, pokud respondent při jiné otázce odpověděl i na připravenou další otázku, může si odpověd' jen zaznamenat a otázku již nevyslovit a pokračovat.

Na závěr stručného pojednání o vedení rozhovoru jen upozorníme na to, že je nutné věnovat pozornost př́ipravě dotazování včetně zvážení vhodného času a prostředí.

Produktem interview jsou odpovědi respondenta, které jsou dnes většinou zaznamenané elektronicky. ${ }^{157}$ Pokud tazatel provádí vlastní prímý zápis odpovědí, je vhodné mít připravené záznamové listy. Podle charakteru dat se provádí transkript, čištění a třídění dat a potom jejich vyhodnocení.

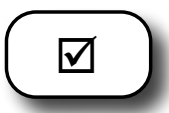

Focus groups je název pro metodu cílených skupinových rozhovorů, který zdomácněl a běžně se používá pod tímto anglickým pojmem (the Focus Group Interview).

\footnotetext{
${ }^{156}$ Dále viz etika a požádání o souhlas respondenta, anonymizace dat, ale také napřiklad povolení vedení organizace, že můžete jeji pracovníky dotazovat atd.

${ }^{157}$ Dríve diktafon apod., dnes CAPI = Computer Assited Personal Interviewing - osobni dotazováni prováděné za pomoci počitače či tabletu, záznam je pořizován přímo elektronicky.
} 
Uvedená výzkumná metoda patři do oblasti kvalitativního výzkumu a nejvíce je využivaná v sociologii a v marketingovém výzkumu. Na základě diskuse s vybraným panelem respondentů pod vedením odborného moderátora získáváme informace o názorech panelistů na zvolené téma či $k$ řešení vybraného problému. Popularita metody v posledních letech vzrostla a při zvolení pro správný účel přináší i vhodné výsledky. ${ }^{158,159}$

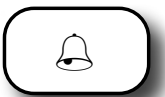

Zvažte:

$\checkmark$ prostředí běžné naši školy je aplikovatelně využitelná i při diskusi v radě školy, v žákovském parlamentu, při třídní schůzce, setkání se skupinou rodičů nebo při workshopu se skupinou učitelů. Nebude se jednat již o výzkum dle pravidel pro aplikaci metody, ale o vedení rozhovoru se skupinou... a získání informací pro marketingové účely. Proto ji zde doporučujeme.

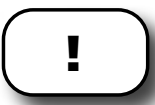

Výzkumná metoda cíleného skupinového rozhovoru je formalizovaný proces, ve kterém malá skupina lidí společně a v interakci diskutuje jedno společné téma nebo koncept.

Cílová skupina se obvykle skládá z 6-12 lidí, jejichž diskusi říí jeden nebo dva vyškolení moderátoři s využitím nestrukturované diskuse, která obvykle trvá 90 minut až dvě hodiny.

\section{Prostřednictvím rozhovoru a diskuse se členy cílové skupiny získávají moderátoři hlubší informace o tématu.}

Výhodou je možnost pochopení myšlenek, poznání očekávání, názorů, zájmů a zkušeností. Metoda je vhodná pro zkoumání chování cílové skupiny, ke zjištování rozdílů ve vnímání mezi kategoriemi v cílové skupině či k hledání způsobů, jak překonat rozpory, řešit problémy apod.

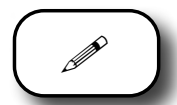

Napřiklad Foret a Stávková (2003 s. 46) uvádějí, že metoda je zejména vhodná pro předvýzkum nebo naopak pro závěrečnou fázi interpretace, „kdy si ještě

\footnotetext{
${ }^{158}$ Významně je uvedena i v publikaci Kotler a Keller (2007) nebo Burns, Veeck, \& Bush (2017).

${ }^{159}$ Využivaji se i online focus groups, jež maji své výhody (např. omezení problémů s cestováním respondentů), ale i nevýhody (např. složitější řizení, překážky v interakci, omezení nonverbální komunikace...).
} 
chceme prohloubit některé poznatky, přijit jim tzv. na kloub, zodpovědět si otázky „proč“““ Kozel, Mynářová \& Svobodová (2011) pro marketingový výzkum metodu přimo doporučuji pro:

- testování reklamních návrhů a konceptů,

- testování návrhů logotypů a značek,

- zjištování pozice značky,

- zjištování kupních či spotřebitelských názorů.

Kotler a Keller (2007 i 2013) s odvoláním na další zdroje uvádějí, že focus groups umožňuji marketérům pozorovat, jak a proč spotřebitelé přijímaji nebo odmítaji určité koncepce, ideje nebo názory. To je také to, co potřebuje znát i zkušené vedení školy.

\section{!}

Obvyklým cílem této metody je získání co nejvíce možných informací o tom, jak lidé (respondenti) chápou předmět výzkumu. Úspěch výzkumu je realizován skupinovou dynamikou $v$ interakci diskuse, kterou vede moderátor. Základní ideou, která je v pozadí, je, že informace od jednoho člověka přecházejí na dalši účastníky skupiny a jsou spontánně interpretovány ostatními. Dochází k efektům náhlé inspirace a doplňování myšlenek, názorů atd.

Důležitou roli hraje osoba moderátora, který by měl být vyškolen v oblasti komunikace a samozřejmě seznámen s metodou a účelem výzkumu. Při vlastní realizaci pomáhá moderátorovi „příposlech“ tj. další pracovník či tým odborníků, který sleduje diskusi a prípadně ji přes moderátora orientuje na požadované oblasti atd. Moderátor musí zejména umět vhodně zahájit diskusi, vést ji, ale neovlivňovat. Pravděpodobně se při vedení diskuse setká i s účastníkem, který se snaži prosadit na úkor dalších nebo naopak s účastníkem, který se málo zapojuje do diskuse. $V$ tomto případě musí umět účastníky vhodně vést až korigovat. ${ }^{160}$ Jeho hlavním úkolem je stimulovat různorodost pohledů a názorů účastníků a jejich diskusi a komentáře k nim.

(:)

Pro určité části skupinové diskuse mohou být připraveny i určité materiály

\footnotetext{
${ }^{160}$ Vysekalová a kol. (2012) s odkazem na další zdroje uváději následujicich pět typů účastniků: aktivni účastník, introvertni jedinec, jedinec, který vše ví a všemu rozumí, „nezadržitelný mluvči“, kverulant.
} 
jako krátké video ${ }^{161} 0 . .$. , návrhy reklamních letáků či brožury školy, nebo přímo ukázkový produkt. Stejně tak pro souhrny a orientaci v dílčích částích diskuse může moderátor využivat tabuli či flipchart.

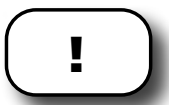

Moderátor musí také počítat $s$ tím, že účastníci nemusí některé v itineráři navržené téma považovat za relevantní, a naopak nastolí dílči téma, které výzkumník při prípravě neuvažoval.

Důležitou poznámku pro moderátora uvádí Gray (2009, s. 389). Při vedení focus groups musí být moderátor připraven na neočekávanou myšlenku či komentáŕ, které se mohou objevit. Moderátor je nesmí komentovat ze svého pohledu, protože je v roli facilitátora diskuse a podporuje získávání pohledů druhých. On sám musí být neutrální.

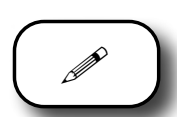

\section{Plánování a realizaci focus groups provedete dle následujících kroků:}

1. Identifikace účelu, definování problému a stanovení cíle. Měli byste vědět, co chcete vědět a proč to chcete vědět, jinak můžete zbytečně ztrácet čas.

2. Pokud je zaměření focus groups exploratorní, je potřebné je dále specifikovat.

Je to považováno za kritickou fázi. Výzkumník musí vymezený účel precizně definovat a vymezit si jaká data potřebuje získat (vytváření scénáře s dílčími otázkami) a kdo může být jejich nositelem.

Kličová rozhodnutí jsou zaměřena na: kdo budou vhodni účastníci, kdo bude vybírat a získávat účastníky, jak velká bude skupina a kde se uskuteční setkání (viz i poznámka o online FG).

\section{Realizace vlastní skupinové diskuse.}

Klíčovou postavou v této fázi je moderátor diskuse. Pro zajištění úspěšného interaktivního setkání musí být pochopena role moderátora všemi účastníky.

Velmi důležitým podkladem je zmíněný itinerář a aplikovaně formulár pro záznam (itinerář může obsahovat i doplňující otázky či informace, jež budou užity během setkání). Vlastní setkání musí být rozděleno na úvodní, hlavní a závěrečnou část, kde také účastníkům poděkujeme.

\footnotetext{
${ }^{161}$ Využijte PC a dataprojektoru.
} 


\section{Analýza výsledků a vytvoření výzkumné zprávy.}

Po skončení setkání musí výzkumník provést analýzu a porovnat poznámky všech zúčastněných (pokud záznam provádí více přísedících). Výzkumník musí vyhodnotit získaná data z diskuse účastníků a napsat zprávu o výzkumu. Zde je důležité si opět uvědomit, pro koho byl výzkum realizován a pro jaký účel je určen a podle toho volit vhodnou formu zprávy.

\section{:}

Pro účel výzkumu musíme ovšem uvažovat možné problémy, např.:

- Reálný obraz získáme, pouze pokud vytvoříme důvěru účastníků a zachováme jejich anonymitu.

- Výsledky, a zejména původně nepředpokládané výsledky, mohou být i velmi závažné a bude záležet na tom, jak budou dále kvalifikovaně interpretovány a využity.

- Mohou také vzniknout logistické problémy se zajištěním potřebného množství vhodných účastníků diskuse (výzkumné agentury je obvykle přiměřeně motivuji).

$* * *$

Z praktického hlediska je důležité pochopení účelu metody, vymezení cílů šetření a vytvoření itineráře pro vedení diskuse, rekrutace účastníků a potom i realizace záznamu diskuse, která se dnes u výzkumných agentur často provádí na kameru a s príposlechem ve speciální místnosti. To je ale ne zcela použitelné ve školní praxi, kde respondenti dnes často nechtějí být zaznamenávání na kameru, a i transkript delší akce by stál velké další úsilí. Proto doporučuji klasický záznam poučeným zapisovatelem, který také předem zná účel a dopisuje dle itineráře poznámky, u kličových vyjádření zaznamenává obsah i prímou větou.

Zpracování dat je spiše tematické se zdůrazněním kličových tvrzení, je to metoda kvalitativního výzkumu! 


\section{? Kontrolní otázky a úkoly:}

- Jaké jsou obvyklé omyly ve vztahu k potřebě marketingového výzkumu školy?

- Dokážete stručně objasnit rozdíl mezi kvantitativním a kvalitativním výzkumem?

- V designu výzkumu jako první volíme otázky nebo metody výzkumu?

- Jaké mohou být nevýhody dotazování s využitím dotazníku?

- Co lze získat aplikaci metody focus groups?

미 Literatura:

Eger, L., \& Egerová, D. (2017). Základy metodologie výzkumu. Plzeň: ZČU v PIzni. Gavora, P. (2010). Úvod do pedagogického výzkumu. Brno: Paido.

Hendl, J., \& Remr, J. (2017). Metody výzkumu a evaluace. Praha: Portál.

Jako alternativní je možné doporučit dokumenty a materiály z projektu NiDV (2016-2021) Strategické řízení a plánování ve školách a v územích. Dostupné z: https://projekty.nidv.cz/strategicke-rizeni 


\section{LITERATURA}

American Marketing Association (2017). Definition of marketing. Dostupné z: https://www.ama.org/listings/2013/01/17/definition-of-marketing/

Armstrong, M. (2007). Řizení lidských zdrojů. Praha: Grada.

Armstrong, M., \& Taylor, S. (2015). Řizení lidských zdrojů. Praha: Grada.

Barth, R. S. (2006). Culture in questions. In The Jossey-Bass Reader on Educational Leadership. San Francisco: Jossey-Bass, s. 159-168.

Barth, R. S. (2013). Culture in question. In. M. Grogan. The Jossey-Bass Reader on Educational Leadership. San Francisco: John Wiley \& Sons. s. 197-206.

Barčík, T. (2012). Marketingová komunikace v turbulentních dobách. Marketing \& komunikace, 22 (1), 7.

Bárta, V., Pátík, L., \& Postler, M. (2009). Retail marketing. Praha: Management Press.

Bedrnová, E., Nový, I. a kol. (1998). Psychologie a sociologie rízení. Praha: Management Press.

M. GroganBelch, G. E., Belch, M. A. (2021). Advertising and Promotion. An Integrated Marketing Communications Perspective. New York: Mc Graw Hill.

Bernstein, D. (1984). Company Image and Reality: A Critique of Corporate communications. Holt, Rinehart \& Winston Ltd.

Brent, D., \& Ellison, L. (1992). School development planning. Harlow: Longman group.

Brent, D., \& Ellison, L (1997). Strategic marketing for school. London: Pitman Publishing,

Burns, A. C., Veeck, A. \& Bush, R, F. (2017). Marketing Research. Harlow: Pearson.

Bush, T. (1995). Theories of Educational Management. London: Paul Chapman Publishing.

Bush, T. (2008) From Management to Leadership: Semantic or Meaningful Change? Educational Management Administration \& Leadership. 36(2), 271-288.

Bush, T. (2013) Distributed leadership: the model of choice in the 21st century. Educational Management Administration \& Leadership, 41(5), 543-544.

Creswell, J. W. (2014). Research Design. Los Angeles: SAGE.

ČŠl (2021). Dostupné z: https://www.csicr.cz/

Deal, T. E., \& Kennedy, A. A. (2000). Corporate Cultures: The Rites and Rituals of Corporate Life. New York: Basic Books. 
Deal, T. E., \& Peterson, K. (1999). Shaping school culture. San Francisco, CA: Jossey-Bass.

Deal, T. E., \& Peterson, K. (2016). Shaping School Culture. San Francisco: John Wiley \& Sons.

De Vierman, M., Cauberghe, V., Hudders, L. \& De Pelsmacker, P. (2017). Consumers' motivations for lurking and posting in brand communities on social networking sites. In. Shelly Rodgers \& Esther Thorson (Eds.) Digital advertising. New York: Routledge.

DiMartino, C., \& Jessen, B. S. (2018). Selling school. The marketing of public relation. New York: Teachers College Press.

Dolan, R., Conduit, J., Fahy, J. \& Goodman, S. (2016). Social media engagement behaviour: a user and gratification perspective. Journal of Strategic Marketing. 24 (3-4), 261-277.

Dzierzgowska, I. (2000). Dyrektor w zreformowanej szkole. Warszawa: CODN.

Education Word. (2014) Is Your School's Culture Toxic or Positive? Dostupné na: http://www.educationworld.com/a_admin/admin/admin275.shtml

Eger, L. (2006). Řizení školy při zavádění školniho vzdělávacího programu. Plzeň: Fraus.

Eger, L. (2019). Aplikace teorie užití a uspokojení, sociální média a značky na sociálních sítích. Trendy v podnikání, 9(3), 1.9-25.

Eger, L. (2020). E-learning a jeho aplikace s orientací na vzdělávání a profesní vzděláváni Millennials. Plzeň: ZČU v Plzni.

Eger a kol. (1998). Efektivní školský management. Plzeň: ZČU v Plzni.

Eger, L., \& Beran, V. (2016) Kultura školy podporující max. rozvoj každého žáka. NiDV. Dostupné z: https://projekty.nidv.cz/strategicke-rizeni

Eger, L. Egerová, D., Tomczyk, L., Krystoň, M., Czeglédi, C. (2020). Facebook for Public Relations in the higher education field: a study from four countries Czechia, Slovakia, Poland and Hungary. Journal of Marketing for Higher Education. Published online: 25 Jun 2020.

Eger, L., Egerová, D. (2001). Image školy. Liberec: TU Liberec.

Eger, L., \& Egerová, D. (2017). Základy metodologie výzkumu. Plzeň: ZČU v Plzni.

Eger, L., Egerová, D., \& Krystoň, M. (2019). Facebook and Public Relations in Higher Education. A Case Study of Selected Faculties from the Czech Republic and Slovakia. Romanian Journal of Communication and Public Relations, 21(1), 7-30.

Eger, L., Egerová, D., \& Pisoňová, M. (2018). Assessment of School Image. Center for Educational Policy Studies Journal, 8(2), 97-122.

Eger, L., Egerová, D., \& Jakubíková, D. (2002) Strategie rozvoje školy. Plzeň: Cechtuma. 
Eger, L., Egerová, D., Petrtyl, J., \& Tlučhoř, J. (2010). Komunikace vzdělávacích organizací s veřejností na internetu. Praha: Educa Service ve spolupráci s Českou andragogickou společností.

Eger, L., \& Jakubíková, D. (2000). Kultura školy. Liberec: TU v Liberci.

Eger, L., Komárková, L., \& Zákružná, V. (2021). Perceptions of Personalization in Company-consumer Interactions on Social Network: Experiment Conducted in the Czech Republic. E+M Ekonomie a Management, 24(2), 153-170.

Eger, L., \& Mičík, M. (2019). Sociální média a značky na sociálních sítích. Marketing \& komunikace, 29(3), 6-7.

Eger, L., Pisoňová, M., \& Tomczyk, L. (2017). Development programs for head teachers in four Central European countries: an international comparison. International Journal Management in Education. 11(1), 25-45.

Eger, L., \& Prášilová, M. (2020). The relation between school culture sub-categories and expected results of learning process. Problems of Education in the 21st Century, 78(1), 48-60.

Elsner, D. (1999). Doskonalenie kierowania placówka oświatowa. Chorzów: Mentor.

Elsner, D. (2001). Jak planovać rozwój placówki oświatowej? Chorzów: Mentor.

Elsner, D., \& Knafel, K. (2000). Jak organizować Wewnatrzszkolne Doskonalenie Nauczycieli? Chorzow: Mentor.

Eurostat. (2021). Digital economy and society statistics. Dostupné z: https:// ec.europa.eu/eurostat/statistics-explained/index.php?title=Digital_economy _and_society_statistics_-_households_and_individuals

Evans, I. (1995). Marketing for Schools. London: CASSEL Education.

Everard, K. B., \& Morris, G. (1996). Effective School Management. London: Paul Chapman Publishing.

Everard, K. B., Morris, G, \& Wilson, I. (2004). Effective School Management. London: Paul Chapman Publishing Ltd.

Fidler, B. (2002). Strategic management for school development. London: Paul Chapman Publishing.

Foret, M. \& Stávková, J. (2003). Marketingový výzkum. Praha: Grada.

Foret, M. (2011). Marketingová komunikace. Brno: Computer Press.

Frankiewicz, B. (2020). Digital Transformation Is About Talent, Not Technology. Harvard Business Review. Dostupné z: https://hbr.org/2020/05/ digital-transformation-is-about-talent-not-technology

Friedlaenderová, H. (2019). Životní styl dětí a jejich mediální chování. Marketing \& komunikace, 24(2), 8-9.

Gavora, P. (2010). Úvod do pedagogického výzkumu. Brno: Paido.

Gray, E. D. (2009). Doing research in the real world. London: SAGE.

Grecmanová, H. (2008). Klima školy. Olomouc: Hanex. 
Grecmanová, H. a kol. (2012), NUOV, Klima školy. Dostupné z: http://www. nuov.cz/uploads/AE/evaluacni_nastroje/14_Klima_skoly.pdf

Grogan, M. a kol. (2013). Educational Leadership. San Francisco: Jossey Bass.

Gruenert, S. (2005). Correlations of Collaborative School Cultures with Student Achievement. NASSP Buletin. 89(645), 43-55.

Gruenert, S. (2008). School Culture, School Climate. Thea are not the same thing. Principal.March/April, 2008.

Hair, Jr., J. F., Ortinau, D. J., Harrison, D. E. (2021). Essentials of Marketing Research. New York: Mc Graw Hill.

Harris, C. (1992). Ritual and educational management: a methodology. International Journal of Educational Management. 6(1), s. 4-9.

Hašková, A. (2010). Kontradikcie hodnotenia atribútov riadenia škôl. e-Pegagogium, 10(88), 103-117.

Hendl, J. (2008). Kvalitativní výzkum. Praha: Portál.

Hendl, J., \& Remr, J. (2017). Metody výzkumu a evaluace. Praha: Portál.

Hlásna, S, Horváthová, K., Mucha, M., \& Tóthová, R. (2006). Úvod do pedagogiky. Nitra: Enigma.

Chráska, M. (2016). Metody pedagogického výzkumu. Praha: Grada.

Chval (2018). Na naši škole nám záleží. Praha: Portál.

Jakubíková, D. (1998). Aplikace marketingu ve školství. Plzeň: ZČU v Plzni.

Jakubíková, D. (2001). Marketing školy. Liberec: TU v Liberci.

Jakubíková, D. (2008). Strategický marketing. Praha: Grada.

Janouch, V. (2010). Internetový marketing. Brno: Computer Press.

Janouch. V. (2020). Internetový marketing. Brno: Computer Press.

Jindří̌̌ek, T., Zvára, M. (2020). Využití sociálních médií pro vaši značku, produkt nebo službu. Marketing \& komunikace, 25(3), 8-9.

Karlíček, M., a kol. (2016). Základy marketingu. Praha: Grada.

Kaushik, A. (2013). See-Think-Do: A Content, Marketing, Measurement Business Framework. Dostupné z: https://www.kaushik.net/avinash/see-think -do-content-marketing-measurement-business-framework/

Klement, M., Chráska, M, \& Chrásková, M. (2015). The use of semantic differential method identifying the opinions of university students on education realized through e-learning. Procedia - Social and Behavioral Sciences, 186, 1214-1223.

Kingsnorth, S. (2019). Digital marketing strategy. London: Kogan Page.

Kotler, P. (2001). Marketing management. Praha: Grada.

Kotler, P. (2003). Marketing od A do Z. Praha: Management Press.

Kotler, P., \& Keller, K. L. (2007). Marketing management. Grada.

Kotler, P., \& Keller, K. L. (2013). Marketing management. Grada.

Kozel, R., Mynářová, L., \& Svobodová, H. (2011). Moderní metody a techniky marketingového výzkumu. Praha: Grada. 
Kulhavy, E. (1993). Skici k marketingu. Praha: Victoria Publishing.

Leithwood, K., Begley, P. T., \& Cousins, J.B. (1994). Developing expert leadership for future schools. London: Falmer Press.

Lukášová, R., Nový I. a kol. (2004). Organizační kultura. Praha: Grada.

Lockhart, M. J. (2016 a). Fundamentals of school marketing. London: Rowman \& Littlefield.

Lockhart, M. J. (2016 b). Maximize your school marketing. London: Rowman \& Littlefield.

Lubienski, Ch. (2007). Marketing Schools. Consumer Goods and Competitive Incentives for Consumer Information. Education and Urban Society. 41(1), 118-141.

Lukášová, R., Nový I. a kol. (2004). Organizační kultura. Praha: Grada.

MacNeil, J.A., Prater, L.D. \& Busch, S. (2009). The effects of school culture and climate on student achievement. International Journal of Leadership in Education. 12(1), 73-84.

Majaro, S. (1996). Základy marketingu. Praha: Grada.

Mareš, J., Ježek, S., \& Mareš, J. (2003-2005) Sociální klima školy. MU v Brně. Dostupné z: http://www.klima.pedagogika.cz/skola/index.html

Martanová, V. P., \& Konůpková, O. (2019). Odlišné světy učitelů a rodičů: interakce s rodiči jako zdroj stresu učitele. Pedagogická orientace, 29(2), s. 223-242.

Mičík. M., \& Kunešová, H. (2021). Using an eye tracker to optimise career websites as a communication channel with Generation Y. Economic Research-Ekonomska Istraživanja. 34(1), 66-89.

Mikušová, M. (1999). Krizový management a kultura organizace. Moderní řízení. 1999, 6, 35-38.

Murgatroyd, S., \& Morgan, C. (1994). Total Quality Management and the School. Buckingham: Open University Press.

Mutinga, D. G., Moorman, M., Verlegh, P. W. J. \& Smit. E. G. (2017). Who creates brand-related content, and why? The interplay of consumer characteristic and motivations. In. Shelly Rodgers \& Esther Thorson (Eds.) Digital advertising. New York: Routledge.

Neumajer, 0. (2007). Náležitosti školního webu - autoevaluační asistent. Dostupné z: https://ondrej.neumajer.cz/nalezitosti-skolniho-webu-auto evaluacni-asistent/

Nezvalová, D. (2002). Kvalita ve škole. Olomouc: UP v Olomouci.

NiDV (2016-2021) Strategické rízení a plánování ve školách a v územích. Dostupné z: https://projekty.nidv.cz/strategicke-rizeni

Nielsen, J. (1994). 10 Usability Heuristics for User Interface Design. Dostupné z: https://www.nngroup.com/articles/ten-usability-heuristics/ 
NPI Praha (2021). Strategické rízení ve školách. Dostupné z: https://vedeme skolu.npi.cz/strategicke-rizeni-ve-skolach/

Němec, P. (1996). Public relations. Zásady komunikace s veřejností. Praha: Managment Press.

Obdržálek, Z. (2002). Škola a jej management. Bratislava: Univerzita Komenského.

Obdržálek, Z., Horváthová, K. a kol. (2004). Organizácia a manažment školství. Bratislava: Slovenské pedagogické nakladatel'stvo.

Oldroyd, D., Elsner, D., \& Poster, C. (1996). Educational Mnagement Today. London: Paul Chapman Publishing.

Osgood, Ch. E., Suci, G. J., \& Tannenbaum, P. (1957). The Measurement of Meaning. University of Illinois Press.

Pauknerová, D. (2006). Psychologie pro ekonomy a manažery. Praha: Grada.

Pavlov, I., Fridrichová, P., Krystoň, M., Purubský, Š., Tomengová, A. (2018). Kariérový systém profesijného rozvoja učitel'ov a model profesijného učenia $v$ škole. Banská Bystrica: Belanium.

Payne, A. (1996) Marketing služeb. Praha: Grada.

Pelsmacker, P. a kol. (2003). Marketingová komunikace. Praha: Grada.

Peters, T., \& Warterman, R. H. (2001). Hledání dokonalosti: Zkušenosti z činnosti nejlépe prosperujicích amerických společností. Praha: PRAGMA.

Petlák, E. (2006). Klíma školy a klíma triedy. Bratislava: IRIS.

Pfeifer, L. \& Umlaufová, M. (1993). Firemní kultura. Praha: Grada.

Pisoňová, M. (2011). Kompetečný profil manažera výchovno-vzdelávacej inštitúcie. Bratislava: Lura edition.

Pisoňová, M. a kol. (2014). Školský management pre študijné odbory učitelstva a prípravu vedúcich pedagogických zamestnancov. Bratislava: Univerzita Komenského.

Pisoňová M. a kol. (2017). Školský manažment, terminologický a výkladový slovník. Bratislava: Wolters Kluwer.

Pol, M., Hloušková, L., Novotný, P., \& Zounek, J. (2005). Kultura školy. Brno: Vydavatelství Masarykovy univerzity v Brně.

Pol, M., Rabušicová, M., Novotný, P. a kol. (2006). Demokracie ve škole. Brno: Masarykova univerzita v Brně.

Pol, M., Hloušková, L., Lazarová, B., Novotný, P. \& Sedláček, M. (2013). Když se školy učí. Brno: Masarykova univerzita v Brně.

Pospišil, J, \& Závodná, S. L. (2009). Mediální výchova. Kralice na Hané: Computer Media.

Postler, M., \& Bárta, V. (2020). Retail marketing. Praha: press21.

Prášilová, M. (2000). Řízení změn v podmínkách současné školy. Učitelské listy. květen 2000, 7(9). II-III. 
Průcha, J. (2006). Přehled pedagogiky. Praha: Portál.

Přibová, M. a kol. (1996). Marketingový výzkum v praxi. Praha: Grada Publishing. Přikrylová, J. a kol. (2019). Moderni marketingová komunikace. Praha: Grada.

Řehoř, P. (2016). Řizení změn. České Budějovice: Jihočeská univerzita v Českých Budějovicích.

Sato, M., Bartiromo, M., \& Elko, S. (2016). Investigating your school's science teaching and learning culture. V9, N6, kapanmagazine.org 3.

Schein, E. H. (984). Coming to a New Awareness of Organizational Culture. Sloan Management Review, 25(2), 3-16.

Schein, E. H. (1996). Culture: the missing concept in organization studies. Administrative Science Quarterly, 41, 229-240.

Schleicher, A. (2012) Ed., Preparing Teachers and Developing School Leaders for 21st Century: Lesons from around the World. OECD Publishing.

Schoolweb (2018). Dostupné z: https://www.scoolweb.cz/

Semerádová, T., \& Weindlich, P. (2019). Marketing na Facebooku a Instagramu. Brno: Computer Press.

Strauss, J., \& Frost, R. (2012). E-marketing. New Jersey: Pearson Education, Sundblad, W. (2020). Here's Why HR Is Critical For Digital Transformation Success. Forbes. Dostupné z: https://www.forbes.com/sites/willemsund bladeurope/2020/09/01/why-hr-is-critical-for-digital-transformation -success/?sh=7313f249216a

Světlík, J. (1996). Marketing školy. Zlín: EKKA.

Světlík, J. (2006). Marketingové rízení školy. Praha: ASPI.

Světlík, J. (2009). Marketingové rízení školy. Praha: Wolters Kluwer ČR.

Světlík, J. a kol. (2016). Marketingové komunikace. Praha: VŠPP Praha.

Světlík, J. (2017). Reklama. Teorie, koncepce, modely. Rzeszów: Vysoká škola informatiky a managementu v Rzeszowě.

Světlík, J. (2018). Marketing, cesta k trhu. Praha: VŠPP a.s.

Světlík, J. (2020). Marketing školy. Prezentace pro projekt SRP NIDV. Prezentace a marketing školy.

Štefko R. (1999). Teoretické východiská skúmania determinantov image vzdelávacej organizácie. Aula, 1, 30-40.

Tahal, R., a kol. (2017). Marketingový výzkum. Postupy, metody, trendy. Praha: Grada.

The Webby Awards (2021). Dostupné z: https://www.webbyawards.com/

Trojan, V., Svobodová, Z. (2019). Subjektivní vnímání proměny role ředitele školy a obtižné prvky výkonu této profese v současné době. Pedagogická orientace, 29(2), s. 203-222.

Trojanová, I. (2014). Ředitel a střední management školy. Praha: Portál. 
Vaštatková, J. (2006). Úvod do autoevaluace školy. Olomouc: Univerzita Palackého.

Vaštíková, M. (2014). Marketing služeb. Efektivně a moderně. Praha: Grada.

Vendemia, M. A. (2017). When do consumers buy the company? Perceptions of interactivity in company-consumer interactions on social networking sites. Computers in Human Behavior, 71, 99-109.

Voda, J. (2015). Nové profesní výzvy učitele po jmenování ředitelem školy. Pedagogika, 65(2), 177-192.

Vykydal, A. (2000). Firemní image. Marketing \& komunikace. 11(3), 8-11.

Vysekalová, J. a kol. (2012). Psychologie reklamy. Praha: Grada.

Vysekalová, J., \& Mikeš, J. (2018). Reklama. Jak dělat reklamu. Praha: Grada.

Vysekalová, J., \& Mikeš, J., Binar, J. (2020). Image a firemní identita. Praha: Grada.

Wagner, R. Ch. (2006). The School Leaders Tool for assessing and improving school culture. Dostupné z: http://www.mssaa.org/gen/mssaa_generated _bin/documents/basic_module/School_culture_triage.pdf

WebTop100 (2021). Dostupné z: https://www.webtop100.cz/

Winmanová, L. (2004). Velká kniha webdesignu. Brno: Zoner Press.

World Economic Forum (2020). Digital Transformation: Powering the Graet Reset. Dostupné z: http://www3.weforum.org/docs/WEF_Digital_Trans formation_Powering_the_Great_Reset_2020.pdf

Zamazalová, M. (2009). Marketing obchodní firmy. Praha: Grada. 


\section{PŘíLOHA A}

Struktura strategického plánovacího procesu... jednotky (podle Kotler, \& Keller, 2013).

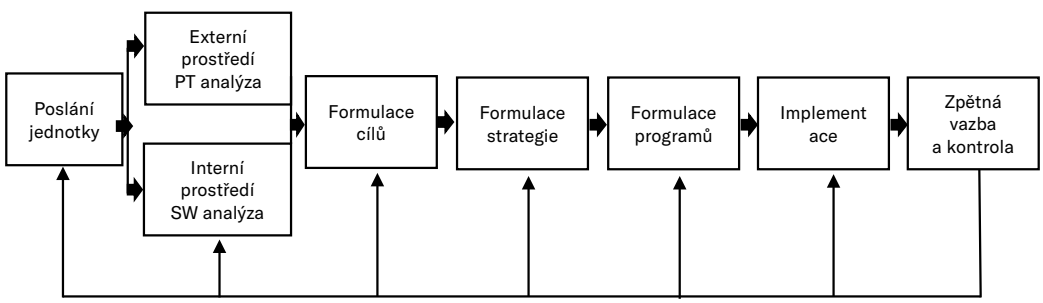

Marketingový plán může mít různé formy, ale obecně obsahuje pět následujicích základních součástí (Belch, \& Belch, 2021).

1. Detailní situační analýzu, jež obsahuje interní marketingový audit a analýzu konkurenčního prostředí a vnějšího prostředí organizace.

2. Měřitelné marketingové cíle, jež poskytuji směr, uvádějí časové rozložení marketingových aktivit a postupy pro měření výkonnosti.

3. Marketingovou strategii a program, který obsahuje výběr cílového trhu či trhů a rozhodnutí či plány pro základní součásti marketingového mixu.

4. Program pro implementaci marketingové strategie, včetně určení specifických úkolů, které musí být splněny a odpovědnost za ně.

5. Proces monitorování a evaluace výkonu, který poskytuje zpětnou vazbu a včasnou kontrolu, jež umožní případnou realizaci potřebných změn ve strategii či taktice organizace. 


\section{PŘíLOHA B}

Marketingový mix a prostředky komunikace

Co do hlavních prostředků komunikace zařadíte z hlediska škol a co přímo z pohledu vaší školy? ( $v$ tomto přehledu pracujeme $s$ rozšířeným mixem marketingové komunikace)

Tabulka X: Složky marketingového mixu a přiklady prostředků komunikace

\begin{tabular}{|c|c|}
\hline Reklama & $\begin{array}{l}\text { Tisková reklama } \\
\text { Rádiové spoty } \\
\text { Regio televize } \\
\text { Billboardy } \\
\text { Plakáty a letáky } \\
\text { Info cedule } \\
\text { Digitální obrazovky }\end{array}$ \\
\hline Podpora prodeje & $\begin{array}{l}\text { Soutěže } \\
\text { Loterie (ples) } \\
\text { Vzorky } \\
\text { Slevy na ... } \\
\text { Dárky } \\
\text { Věrnostni předměty }\end{array}$ \\
\hline Public Relations & $\begin{array}{l}\text { Výroční zprávy } \\
\text { Tzv. tiskové balíčky } \\
\text { Projevy } \\
\text { Semináře } \\
\text { CSR akce } \\
\text { Časopis } \\
\text { Lobování } \\
\text { Nástěnky }\end{array}$ \\
\hline Osobní prodej & $\begin{array}{l}\text { Osobní prezentace } \\
\text { Schůzky s rodiči aj. } \\
\text { Incentivni programy } \\
\text { Vystoupení na veletrhu }\end{array}$ \\
\hline WOM $^{*}$ & $\begin{array}{l}\text { Komunikace v síti lidí } \\
\text { Sociální média }\end{array}$ \\
\hline
\end{tabular}




\begin{tabular}{|l|l|}
\hline & Sportovni \\
& Kulturní \\
& Vzdélávaci \\
& Exkurze \\
& Akce v obci \\
\hline & www stránky \\
& SMS, mailling \\
\hline Interaktivní marketing* & E-shop \\
& Blog \\
\hline & Aplikace \\
\hline
\end{tabular}

*zejména sem bude patřit př́mý marketing

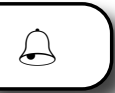

1. Tabulku určitě můžete doplnit.

2. Některé prostředky je možné zařadit do více „škatulek“. Příkladem je veletrh vzdělávání (reklama, podpora prodeje, osobní prodej, WOM) či využití sociálních médií (reklama, WOM, osobní prodej).

3. Analyzujte možné interakce s cillovými skupinami = součást auditu vaší marketingové komunikace.

Doplňující pohled

Komunikační kanály mohou být osobní a neosobní. Podivejte se opět na vámi vytvořený seznam a rozdělte jej do:

Kanály osobní komunikace - poradci, experti, společenské kanály (web x slova).

Ve škole:

Neosobní kanály - zaměřené více než na jednu osobu: média (tiskové, vysilané, sítové, elektronické a prostředky vystavení), podpora prodeje (spotřebitelské a firemní akce, motivace prodejní síly), události, Public Relations a publicita.

Ve škole:

\section{A nezapomeňte, že důležitá je jejich účelná integrace.}




\section{PR̆ÍLOHA C}

\section{Výroční zpráva školy}

Velmi významným prostředkem propagace ve školství je výroční zpráva. Ta je dokonce daná i Školským zákonem (561/2004 Sb., v platném znění ke dni 13. 10. 2020, § 10).

Ředitel základní, střední a vyšší odborné školy zpracovává každoročně výroční zprávu o činnosti školy za školní rok, zasílá ji zřizovateli a zveřejňuje vždy na přístupném místě ve škole. Do výroční zprávy může každý nahližet a pořizovat si z ní opisy a výpisy, anebo za cenu v místě obvyklou může obdržet jeji kopii. Poskytování informací podle zákona o svobodném přistupu k informacím tím není dotčeno.

Ministerstvo potom podle tohoto zákona a $§ 11$ prováděcím právním předpisem stanovilo rámcovou strukturu, obsah a postup zpracování .... výročních zpráv podle $\S 10$ odst. ... a termíny jejich předkládání a zveřejňování.

Vyhláška č. 152005 Sb., kterou se stanoví náležitosti dlouhodobých záměrů, výročních zpráv. Vše je dostupné na https://www.msmt.cz/

§ 7 Obsah a zpracování výroční zprávy o činnosti školy (výběr informací):

(1) Výroční zpráva o činnosti školy obsahuje vždy: a) základní údaje o škole...., b) přehled oborů vzdělání, které škola vyučuje v souladu se zápisem ve školském rejstříku, c) rámcový popis personálního zabezpečení činnosti školy, d) údaje o príijímacím řízení nebo o zápisu k povinné školní docházce... e) údaje o výsledcích vzdělávání žáků podle cílů stanovených vzdělávacími programy..., f) údaje o prevenci sociálně patologických jevů, g) údaje o dalším vzdělávání pedagogických pracovníků, h) údaje o aktivitách a prezentaci školy na) veřejnosti, i) údaje o výsledcích inspekční činnosti..., j) základní údaje o hospodaření školy, k) údaje o zapojení školy do rozvojových a mezinárodních programů, l) údaje o zapojení školy do dalšího vzdělávání..., m) údaje 0 ... projektech..., n) údaje o spolupráci s odborovými organizacemi, organizacemi zaměstnavatelů a dalšími partnery při plnění úkolů ve vzdělávání. 


\section{$?$}

V letech 2019/2020 jsem se při workshopech k marketingu školy setkal v několika krajích s tím, že VZ byly „suché“, plné rozsáhlých tabulek a výčtů, dokonce i bez fotografií a oslovení čtenářů. Prý to po nich zřizovatelé a Čšı vyžaduji, aby si to mohli zkontrolovat dle vyhlášky!

\section{!}

VZ je velmi efektivní, pokud řekne jejím čtenár̆ům (cílovým skupinám) jasně a přehledně to, co oni chtějí vědět 0 škole. Zvažte? Který rodič dokáže číst výše uvedenou dlouhou a nudnou formu VZ? A proč, že?

Ano, VZ by měla být profesionálně připravena a musí splnit i požadavky výše uvedeného zákona a vyhlášky (tabulky do přilohy?), ale musí především umět oslovit, a i přitáhnout čtenáře. Měla by být spiše stručnější a komunikovat zejména ten nejdůležitějši obsah! Opět je vhodné využivat i grafické ztvárnění, jež koresponduje s designem materiálů školy a zpřehledňuje zprávu pro čtenáře.

Kladu si otázku: jak mohou suché tabulkové VZ vyprávět veřejnosti pozitivní přiběh o každé naši diliči škole a přispivat tak nejenom k povědomí, jak vzdělávání je důležité, a že je mu věnována i patřičná pozornost zúčastněných, ale i k propagaci dobrého jména té, které školy, jejich učitelů, žáků, dalších pracovníků i spolupracujicích organizací a jedinců? 


\section{PŘ́lLOHA D}

\section{Schéma marketingového auditu školy}

- Uvnitř schématu máme stručně vyjmenované základni složky vnitřního prostředí školy, které je nutné v auditu hodnotit (kvalita managementu, kvalita pracovníků, strategie školy, vzdělávaci program, finanční situace, vybavení školy, historie, kultura školy, image). Můžeme též použít VRIO analýzu.

- V obdélnících zprava i zleva jsou pojmenované důležité fenomény mikroprostředí (mezoprostředí) školy. Viz i Portetorova analýza pěti sil v textu publikace.

- V šipkách jsou pojmenované nejdůležitější součásti analýzy vnějšího prostředí, PEST analýza.

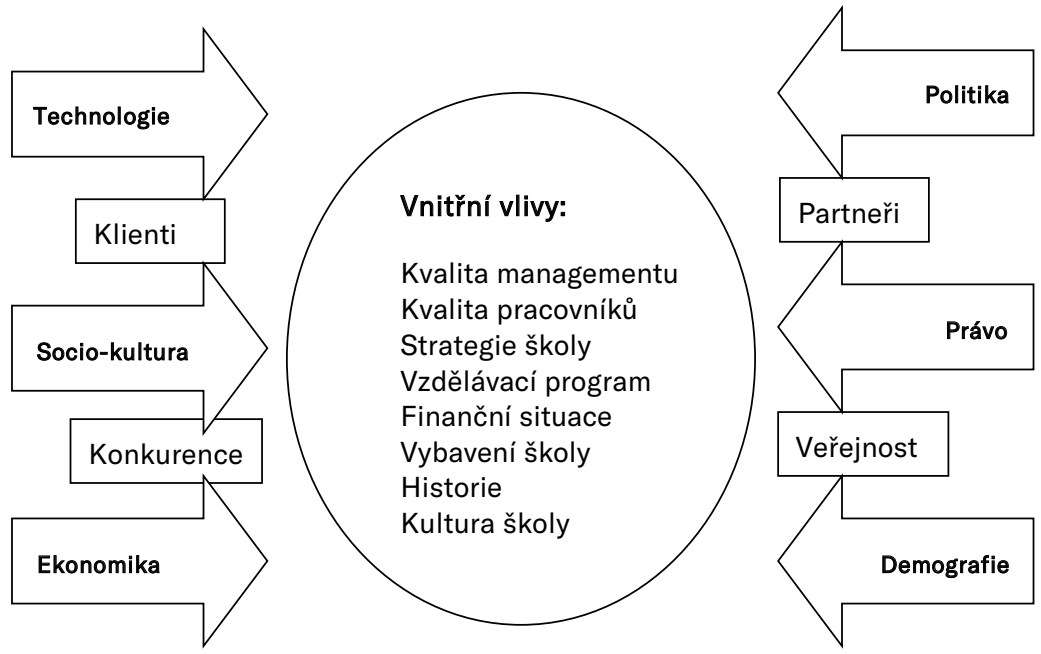

\section{!}

Výstup shrnete ve SWOT analýze školy. 


\section{PŘíLOHA E}

\section{Dotazník: Kultura školy}

Pokyny:

1. kroužkem označte hodnocení faktoru - současný stav

(kroužek $\mathbf{O}$ umístěte do př́slušného - vybraného pole)

2. potom křižkem označte u každého faktoru požadovaný (očekávaný) stav (křižek X umistěte do príslušného - vybraného pole)

\begin{tabular}{|c|c|c|c|c|c|}
\hline FAKTOR & 1 & 2 & 3 & 4 & 5 \\
\hline SPOLEČNÉ CÍLE & $\begin{array}{l}\text { Žádné } \\
\text { povědomí } \\
\text { o cílech } \\
\text { školy, } \\
\text { neúćast na } \\
\text { plánování }\end{array}$ & $\begin{array}{l}\text { Malá znalost } \\
\text { cilů a nízká } \\
\text { účast na } \\
\text { plánování }\end{array}$ & $\begin{array}{l}\text { Průměrné } \\
\text { povědomí } \\
\text { o cílech, } \\
\text { možnost } \\
\text { účasti na } \\
\text { plánování }\end{array}$ & $\begin{array}{l}\text { Dobrá } \\
\text { znalost cílů, } \\
\text { účast na } \\
\text { společném } \\
\text { plánování }\end{array}$ & $\begin{array}{l}\text { Úplná } \\
\text { znalost } \\
\text { společných } \\
\text { cílů, jasná } \\
\text { orientace, } \\
\text { společný } \\
\text { plán }\end{array}$ \\
\hline $\begin{array}{l}\text { DŮVĚRA } \\
\text { VE VEDENÍ ŠKOLY }\end{array}$ & $\begin{array}{l}\text { Nedůvěra ve } \\
\text { vedení školy }\end{array}$ & $\begin{array}{l}\text { Nízká důvěra } \\
\text { ve vedení } \\
\text { školy }\end{array}$ & $\begin{array}{l}\text { Průměrná } \\
\text { či částečná } \\
\text { důvěra ve } \\
\text { vedení školy }\end{array}$ & $\begin{array}{l}\text { Velmi dobrá } \\
\text { důvěra ve } \\
\text { vedení školy }\end{array}$ & $\begin{array}{l}\text { Vysoká } \\
\text { důvěra ve } \\
\text { vedení školy }\end{array}$ \\
\hline $\begin{array}{l}\text { PŘEVLÁDAJÍCÍ STYL } \\
\text { Ř́ZZENI VE VZTAHU } \\
\text { K LIDEM }\end{array}$ & $\begin{array}{l}\text { Neexistuje } \\
\text { možnost } \\
\text { spoluúčasti } \\
\text { na řízení } \\
\text { a rozhodování }\end{array}$ & $\begin{array}{l}\text { Jsou omeze- } \\
\text { né možnosti } \\
\text { vyjádření se, } \\
\text { názory jiných } \\
\text { se berou } \\
\text { v úvahu jen } \\
\text { zřídka }\end{array}$ & $\begin{array}{l}\text { Pracovníci } \\
\text { maji možnost } \\
\text { se k věcem } \\
\text { vyjádřit, } \\
\text { někdy je } \\
\text { to bráno } \\
\text { v úvahu při } \\
\text { rozhodování }\end{array}$ & $\begin{array}{l}\text { Vedení } \\
\text { obvykle } \\
\text { k názorům } \\
\text { pracovníků } \\
\text { hodně } \\
\text { přihliží a vy- } \\
\text { užívá je i při } \\
\text { rozhodování }\end{array}$ & $\begin{array}{l}\text { Pracovníci } \\
\text { maji vždy } \\
\text { možnost } \\
\text { se vyjádřit } \\
\text { k důležitým } \\
\text { otázkám, je } \\
\text { velká snaha } \\
\text { dosáhnout } \\
\text { v zásadních } \\
\text { věcech } \\
\text { konsensu }\end{array}$ \\
\hline $\begin{array}{l}\text { REŽIM ŠKOLY } \\
\text { A ORGANIZAČNÍ } \\
\text { STRUKTURA }\end{array}$ & $\begin{array}{l}0 \text { režimu } \\
\text { nelze mluvit, } \\
\text { struktura } \\
\text { organizace je } \\
\text { nefunkčni }\end{array}$ & $\begin{array}{l}\text { Formální } \\
\text { režim i struk- } \\
\text { tura nejsou } \\
\text { dodržovány, } \\
\text { delegování } \\
\text { nefunguje }\end{array}$ & $\begin{array}{l}\text { Jsou zde } \\
\text { režim } \\
\text { a struktura } \\
\text { s některými } \\
\text { problémy, } \\
\text { klady } \\
\text { i zápory, } \\
\text { delegování je } \\
\text { spiše malé }\end{array}$ & $\begin{array}{l}\text { Dobrý } \\
\text { režim školy } \\
\text { s fungujicí } \\
\text { organizační } \\
\text { strukturou, } \\
\text { dochází } \\
\text { k delegování }\end{array}$ & $\begin{array}{l}\text { Velmi dobře } \\
\text { zaběhlý } \\
\text { a dodržovaný } \\
\text { režim, funkč- } \\
\text { ní struktura } \\
\text { včetně } \\
\text { delegování } \\
\text { pravomocí }\end{array}$ \\
\hline
\end{tabular}




\begin{tabular}{|c|c|c|c|c|c|}
\hline $\begin{array}{l}\text { ZAMĚŘENÍ VEDENÍ } \\
\text { NA PRACOVNÍ ÚKOLY }\end{array}$ & $\begin{array}{l}\text { Je zde } \\
\text { velmi nízká } \\
\text { orientace na } \\
\text { výkon }\end{array}$ & $\begin{array}{l}\text { Výkonové } \\
\text { ukazatele } \\
\text { a výsledky } \\
\text { práce nejsou } \\
\text { hlavní }\end{array}$ & $\begin{array}{l}\text { Výsledky } \\
\text { a výkony se } \\
\text { sleduji někdy } \\
\text { více, někdy } \\
\text { méně }\end{array}$ & $\begin{array}{l}\text { Výsledkům } \\
\text { a výkonnosti } \\
\text { se věnuje } \\
\text { náležitá } \\
\text { pozornost }\end{array}$ & $\begin{array}{l}\text { Škola je } \\
\text { vysoce } \\
\text { orientována } \\
\text { na výkon, } \\
\text { plnění úkolů } \\
\text { se velmi } \\
\text { sleduje }\end{array}$ \\
\hline KONTROLA & $\begin{array}{l}\text { Chybí účinná } \\
\text { kontrola } \\
\text { téměř všeho } \\
\text { a všech }\end{array}$ & $\begin{array}{l}\text { Kontrola je } \\
\text { zaměřena } \\
\text { pouze na } \\
\text { vyhledávání } \\
\text { viníků }\end{array}$ & $\begin{array}{l}\text { Kontrola je } \\
\text { průměrně } \\
\text { přísná } \\
\text { a intenzivní } \\
\text { s průměrným } \\
\text { zaměřením } \\
\text { na všechny }\end{array}$ & $\begin{array}{l}\text { Kontrola } \\
\text { je na } \\
\text { dobré úrovni, } \\
\text { hledaji se } \\
\text { i príčiny } \\
\text { problémů, } \\
\text { nejen viníci }\end{array}$ & $\begin{array}{l}\text { Kontrola je } \\
\text { systematická } \\
\text { a kvalitní, } \\
\text { zaměřená } \\
\text { na hledání } \\
\text { přičin i na } \\
\text { prevenci, } \\
\text { postihuje } \\
\text { vše }\end{array}$ \\
\hline $\begin{array}{l}\text { MOTIVACE } \\
\text { PRACOVNÍKU }\end{array}$ & $\begin{array}{l}\text { Motivaci } \\
\text { pracovníků } \\
\text { se nepři- } \\
\text { kládá žádný } \\
\text { význam }\end{array}$ & $\begin{array}{l}\text { Pracovníci } \\
\text { jsou mi- } \\
\text { nimálně } \\
\text { motivováni } \\
\text { k práci }\end{array}$ & $\begin{array}{l}\text { Motivace } \\
\text { pracovníků je } \\
\text { průměrná }\end{array}$ & $\begin{array}{l}\text { Motivace } \\
\text { pracovníků } \\
\text { je na dobré } \\
\text { úrovni }\end{array}$ & $\begin{array}{l}\text { Motivace ve } \\
\text { škole vede } \\
\text { k vysokému } \\
\text { nasazení, má } \\
\text { systém }\end{array}$ \\
\hline $\begin{array}{l}\text { KOMUNIKACE } \\
\text { A INFORMOVONOST } \\
\text { PRACOVNÍKŮ ŠKOLY }\end{array}$ & $\begin{array}{l}\text { Minimální } \\
\text { až žádná } \\
\text { informova- } \\
\text { nost, závažné } \\
\text { problémy } \\
\text { v komunikaci }\end{array}$ & $\begin{array}{l}\text { Spiše špatná } \\
\text { informova- } \\
\text { nost, důležité } \\
\text { informace } \\
\text { dost často } \\
\text { chybí }\end{array}$ & $\begin{array}{l}\text { Střední } \\
\text { informova- } \\
\text { nost, občas } \\
\text { se objevuje } \\
\text { zadržování } \\
\text { určitých } \\
\text { informací }\end{array}$ & $\begin{array}{l}\text { Dobrá infor- } \\
\text { movanost, } \\
\text { pracovníci } \\
\text { maji potřeb- } \\
\text { né informace, } \\
\text { komunikace } \\
\text { bez problémů }\end{array}$ & $\begin{array}{l}\text { Výborná in- } \\
\text { formovanost, } \\
\text { komunikace } \\
\text { probihá } \\
\text { jak shora } \\
\text { dolů, tak } \\
\text { zdola nahoru } \\
\text { i horizontálně }\end{array}$ \\
\hline $\begin{array}{l}\text { KOMUNIKACE ŠKOLY } \\
\text { S OKOLIMM A RODIČI }\end{array}$ & $\begin{array}{l}\text { Nedostateč- } \\
\text { ná, vykazuje } \\
\text { řadu ne- } \\
\text { dostatků } \\
\text { a nedorozu- } \\
\text { mění }\end{array}$ & $\begin{array}{l}\text { Škola se jí } \\
\text { věnuje málo, } \\
\text { je spíše } \\
\text { podprůměrná }\end{array}$ & $\begin{array}{l}\text { Je asi } \\
\text { dostatečná, } \\
\text { jsou zde } \\
\text { přiležitosti } \\
\text { pro zlepšení }\end{array}$ & $\begin{array}{l}\text { Je dobrá, } \\
\text { zaměřená } \\
\text { především na } \\
\text { rodiče }\end{array}$ & $\begin{array}{l}\text { Velmi } \\
\text { kvalitní, } \\
\text { škola vě- } \\
\text { nuje velkou } \\
\text { pozornost } \\
\text { komunikaci } \\
\text { s partnery } \\
\text { a zejména } \\
\text { s rodiči }\end{array}$ \\
\hline INOVATIVNOST & $\begin{array}{l}\text { Projevy } \\
\text { inovativnosti } \\
\text { prakticky } \\
\text { nejsou, } \\
\text { není pro ně } \\
\text { podpora }\end{array}$ & $\begin{array}{l}\text { Inovativnost } \\
\text { pracovníků } \\
\text { se nevyža- } \\
\text { duje, malá } \\
\text { inovativnost }\end{array}$ & $\begin{array}{l}\text { Inovativnost } \\
\text { je jen } \\
\text { průměrná, } \\
\text { většinou } \\
\text { vyvolaná jen } \\
\text { naléhavou } \\
\text { nutností }\end{array}$ & $\begin{array}{l}\text { Inovativnost } \\
\text { pracovníků } \\
\text { je všude } \\
\text { patrná, je } \\
\text { ceněna }\end{array}$ & $\begin{array}{l}\text { Mimořádná } \\
\text { inovativnost, } \\
\text { škola je po- } \\
\text { važována za } \\
\text { průkopníka }\end{array}$ \\
\hline
\end{tabular}




\begin{tabular}{|c|c|c|c|c|c|}
\hline ROZVOJ UČITELŮ & $\begin{array}{l}\text { Neexistuje } \\
\text { jasná } \\
\text { personální } \\
\text { politika, } \\
\text { DVPP se } \\
\text { nepodporuje }\end{array}$ & $\begin{array}{l}\text { Personální } \\
\text { politika je } \\
\text { založena } \\
\text { na intuici, } \\
\text { DVPP téměř } \\
\text { neprobíhá }\end{array}$ & $\begin{array}{l}\text { Personální } \\
\text { politika } \\
\text { existuje spíš } \\
\text { na papíre, } \\
\text { v praxi } \\
\text { se hodně } \\
\text { porušuje, } \\
\text { DVPP se } \\
\text { přikládá malý } \\
\text { význam }\end{array}$ & \begin{tabular}{|l} 
Jasná \\
personální \\
politika, \\
která se \\
v zásadě \\
dodržuje \\
a podporuje \\
včetně DVPP
\end{tabular} & $\begin{array}{l}\text { Jasná } \\
\text { personální } \\
\text { politika, } \\
\text { vysoká } \\
\text { podpora } \\
\text { rozvoje uči- } \\
\text { telů a jejich } \\
\text { DVPP }\end{array}$ \\
\hline $\begin{array}{l}\text { PRACOVNÍ } \\
\text { PODMÍNKY PRO } \\
\text { VÝUKU }\end{array}$ & $\begin{array}{l}\text { Velmi špatné, } \\
\text { neodpovídaji } \\
\text { zákonným } \\
\text { normám }\end{array}$ & $\begin{array}{l}\text { Spíše špatné, } \\
\text { v určitých } \\
\text { případech } \\
\text { neodpovídaji } \\
\text { normám }\end{array}$ & $\begin{array}{l}\text { Průměrné, } \\
\text { něco by } \\
\text { mohlo být } \\
\text { určitě i lepši }\end{array}$ & $\begin{array}{l}\text { Dobré } \\
\text { pracovní } \\
\text { podmínky } \\
\text { pro práci uči- } \\
\text { telů a dalších } \\
\text { pracovníků }\end{array}$ & $\begin{array}{l}\text { Vynikajicí } \\
\text { pracovní } \\
\text { podmínky, } \\
\text { které berou } \\
\text { v úvahu } \\
\text { i individuální } \\
\text { potřeby } \\
\text { pracovníků } \\
\text { školy }\end{array}$ \\
\hline $\begin{array}{l}\text { ESTETICKÉ } \\
\text { PROSTŘEDÍ } \\
\text { A POŘÁDEK }\end{array}$ & $\begin{array}{l}\text { Velmi špatná } \\
\text { estetická } \\
\text { úroveň, } \\
\text { nepořádek až } \\
\text { špína }\end{array}$ & \begin{tabular}{|l} 
Špatná \\
estetická \\
úroveň \\
včetně \\
problémů \\
s hygienou \\
a úklidem
\end{tabular} & $\begin{array}{l}\text { Vcelku dobrá } \\
\text { estetická } \\
\text { úroveň, } \\
\text { čistota } \\
\text { pracoviště }\end{array}$ & $\begin{array}{l}\text { Velmi dobrá } \\
\text { estetická } \\
\text { úroveň } \\
\text { pracoviště, } \\
\text { bez problémů }\end{array}$ & $\begin{array}{l}\text { Výjimečná } \\
\text { estetická } \\
\text { úroveň } \\
\text { pracovišt } \\
\text { i pracovníků, } \\
\text { která podpo- } \\
\text { ruje image }\end{array}$ \\
\hline $\begin{array}{l}\text { VZTAHY MEZI } \\
\text { PRACOVNÍKY }\end{array}$ & $\begin{array}{l}\text { Špatné } \\
\text { vztahy } \\
\text { některé až } \\
\text { nepřátelské }\end{array}$ & $\begin{array}{l}\text { Vztahy } \\
\text { nejsou } \\
\text { vyrovnané, } \\
\text { spolupráce je } \\
\text { nízká }\end{array}$ & $\begin{array}{l}\text { Vztahy } \\
\text { umožňuji } \\
\text { potřebnou } \\
\text { spolupráci }\end{array}$ & $\begin{array}{l}\text { Vztahy } \\
\text { jsou dobré, } \\
\text { pracovníci } \\
\text { spolupracuji }\end{array}$ & $\begin{array}{l}\text { Výborné } \\
\text { vztahy, klima } \\
\text { podporuje } \\
\text { týmovou } \\
\text { spolupráci }\end{array}$ \\
\hline $\begin{array}{l}\text { VZTAHY MEZI } \\
\text { UČITELI A ŽÁKY }\end{array}$ & $\begin{array}{l}\text { Vztahy jsou } \\
\text { špatné, } \\
\text { vyskytuji se } \\
\text { i závažné } \\
\text { problémy }\end{array}$ & $\begin{array}{l}\text { Vztahy } \\
\text { mohou být } \\
\text { lepší, často } \\
\text { se vyskytují } \\
\text { problémy }\end{array}$ & $\begin{array}{l}\text { Interakce je } \\
\text { průměrná } \\
\text { s výkyvy na } \\
\text { obě strany }\end{array}$ & $\begin{array}{l}\text { Dobré vztahy } \\
\text { přispívají } \\
\text { k pohodě } \\
\text { při výuce ve } \\
\text { škole }\end{array}$ & $\begin{array}{l}\text { Výborné } \\
\text { vztahy } \\
\text { a klima } \\
\text { důvěry } \\
\text { přispívaji } \\
\text { k výsledkům } \\
\text { školy }\end{array}$ \\
\hline $\begin{array}{l}\text { OČEKÁVÁNÍ } \\
\text { VÝSLEDKŮ } \\
\text { VZDĚLÁVÁNÍ }\end{array}$ & $\begin{array}{l}\text { Neočekávají } \\
\text { se dobré } \\
\text { výsledky, } \\
\text { není o ně } \\
\text { zájem }\end{array}$ & $\begin{array}{l}\text { Je zde spíše } \\
\text { nízké očeká- } \\
\text { vání výsledků } \\
\text { vzdělávání }\end{array}$ & $\begin{array}{l}\text { Očekává se } \\
\text { dosažení } \\
\text { požadované- } \\
\text { ho standardu }\end{array}$ & $\begin{array}{l}\text { Očekává se } \\
\text { dosažení } \\
\text { nadprů- } \\
\text { měrných } \\
\text { výsledků }\end{array}$ & $\begin{array}{l}\text { Vysoké } \\
\text { očekávání } \\
\text { výborných } \\
\text { a vyni- } \\
\text { kajících } \\
\text { výsledků } \\
\text { výuky }\end{array}$ \\
\hline
\end{tabular}

Děkujeme za vyplněni dotazníku. 


\section{PŘíLOHA F}

\section{Dotazník: Image školy}

POKYN: zakroužkujte na škále hodnocení v jednotlivých položkách dotazníku

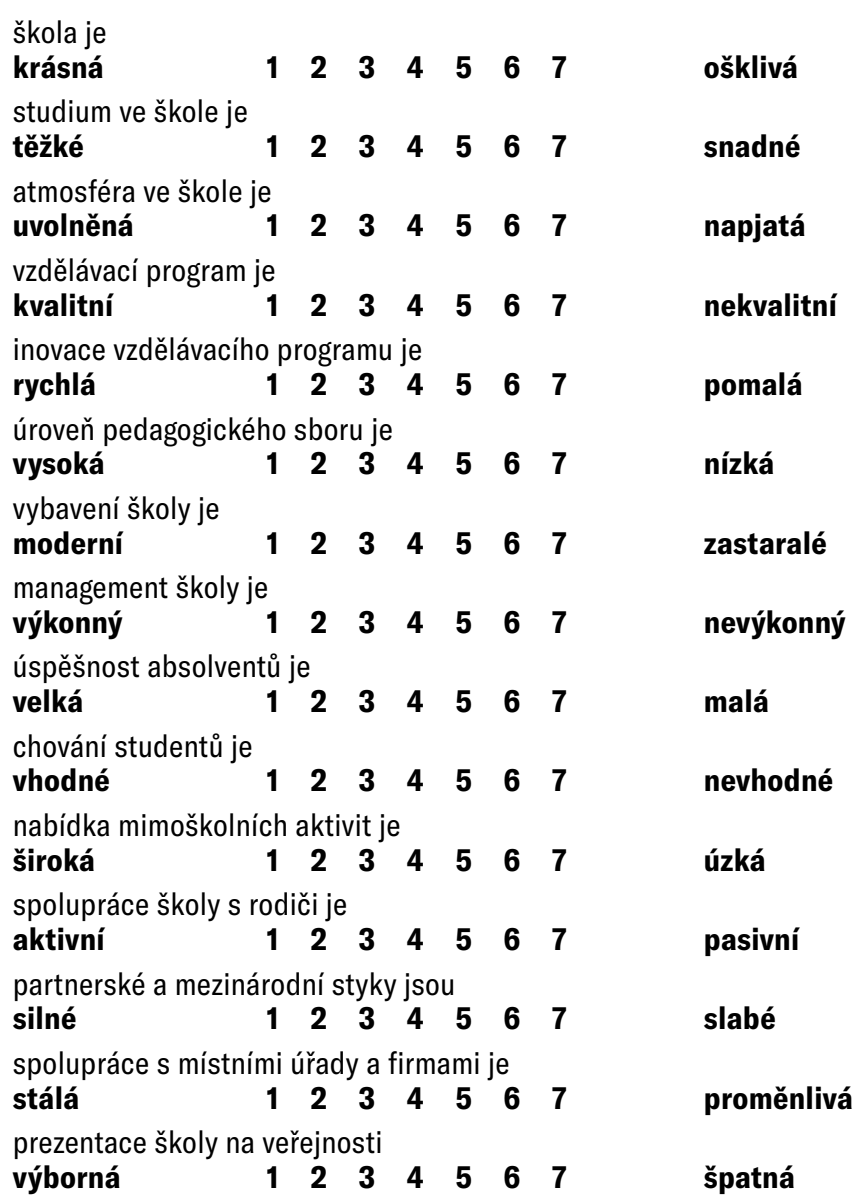

Děkujeme za vyplnění dotazníku. 


\section{PŘíLOHA G}

\section{Portfoliová analýza BCG}

Portfoliová analýza BCG (Boston Consulting Group) je populární jako matice růst-podíl. Portfolio produktů (vzdělávacích programů, kurzů) si promítáme ve dvou dimenzích:

- V horizontální poloze je vyjádřen relativní podíl produktu, tj. například vzdělávaciho programu, ale také celého vzdělávacího subjektu na trhu ve vztahu ke konkurenci.

- Ve vertikální poloze představuje roční tempo růstu, ve kterém je produkt (vzdělávací služba) nabízen - prodáván.

Světlík (1996, 2009) uvádí, že tento přístup může být aplikován i na analýzu portfolia vzdělávací instituce.

Každý produkt - vzdělávací program, kurz můžeme posuzovat ze dvou hledisek: tempo růstu můžeme vyjádřit počtem studentů a relativní podíl na trhu můžeme vyjádřit srovnáním s konkurencí v této oblasti. ${ }^{162}$

Matice BCG

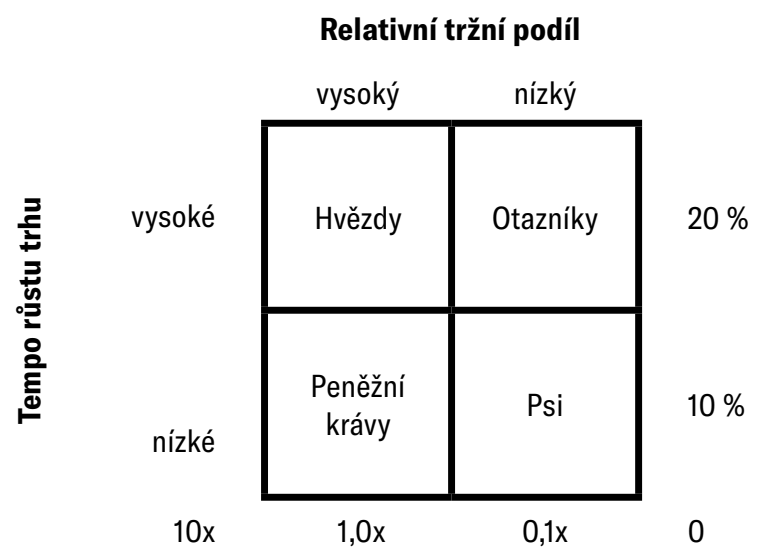

\footnotetext{
${ }^{162}$ Ve firemním prostředi se do uvedené matice zobrazuje kruh s umístěním produktu a jeho velikost vyjadřuje i objem prodeje a tím i význam pro celkový obrat firmy... (Jakubíková, 2008). V oblasti školství je tato aplikace spíše neobvyklá, ale umíme si představit, že má význam pro soukromé subjekty.
} 
Stručný popis jednotlivých kvadrantů:

- Otazníky. Jedná se o vzdělávací programy, kurzy či aktivity, které se uskutečňuji na trhu s vysokým tempem růstu, ale vykazuji nízké tržní podily. Otazník vyžaduje velké finanční aj. zdroje, pokud jej chceme posunout do efektivnějších kvadrantů.

- Hvězdy. Úspěšný program, kurz se stává hvězdou. Má vedoucí postavení na trhu, kde prudce roste zájem o vzdělávání v této oblasti.

- Peněžní krávy. Jestliže roční tempo rủstu klesne pod $10 \%$ a za předpokladu, že má hvězda velký podíl na trhu, stává se pro vzdělávací subjekt tento program, kurz peněžní krávou. Není potřeba již velkých investic, jedná se např. o zavedený, potřebný, kvalitní program, kurz s dobrou pověstí, který je ziskový a přináší peněžni prostředky.

- Psi. Představuji programy, kurzy, které mají slabé tržní podíly s nízkým tempem růstu. Produkuji nízké zisky nebo dokonce ztrátu. Záleží na okolnostech. Vzdělávací subjekt může z různých důvodů držet i kurzy v úrovni psů (špičková úroveň kurzů, perspektiva z dlouhodobého pohledu, image centra, školy ...).

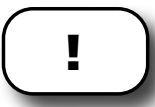

Po zhodnocení svých programů, kurzů podle uvedeného portfolia, můžeme diskutovat o tom, zda je portfolio vzdělávacích programů (kurzů) naší školy či vzdělávací instituce zdravé a připravit se pro následujicí rozhodování v oblasti cílů, strategie a rozpočtů. Kotler (2001) uváděl, že principiálně máme tyto možnosti:

1. Budovat. Zvýšit podíl programu či kurzu na trhu. Je to vhodné hlavně pro otazníky.

2. Udržovat. Ochraňovat tržní podíl, je to vhodné zejména pro peněžní krávy.

3. Sklizet. Cílem je zvýšení krátkodobého peněžního toku bez ohledu na dlouhodobé účinky. Strategie je vhodná pro peněžní krávy, kde je nejistá budoucnost na trhu.

4. Zbavovat se. Zde je cílem prodat nebo ukončit program či kurz. Uvolněné zdroje je možné výhodněji použít pro jiné aktivity. Týká se to zejména psů a otazníků. 


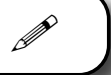

Světlík (2006): Po analýze portfolia svého vzdělávacího programu může vedení školy zjistit slabá místa v nabídce školy. Potom navrhuje následující čtyři základní strategie:

- Strategie pronikání, snaha získat co nejvíce studentů při existující nabídce vzdělávacích programů.

- Strategie rozvoje vzdělávacích programů, nové studijní obory, které reaguji na změny, zvýšení atraktivity školy. Je to působení na stále stejný trh.

- Strategie rozvoje trhu, jedná se bud' o geografickou expanzi stávajících studijních programů nebo o nabídku stávajících oborů novým segmentům studentů.

- Strategie diverzifikace, otevření nových studijních oborů pro nové trhy.

Zvažte:

Každá strategie představuje rozdílná rizika pro vedení školy při jejím uplatňování. 


\section{PŘ́lLOHA H}

\section{Metoda terče}

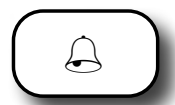

Tento jednoduchý nástroj můžete použít pro aktivity vašeho marketingového týmu. Lze také využít v rámci focus groups pro strukturaci diskuse se zástupci cílové skupiny pro hledání problémů, námětů apod.

Pokyn:

Zapište 4-5 oblastí a přidejte jim důležitost podle terče, střed je nejdůležitější!

\section{!}

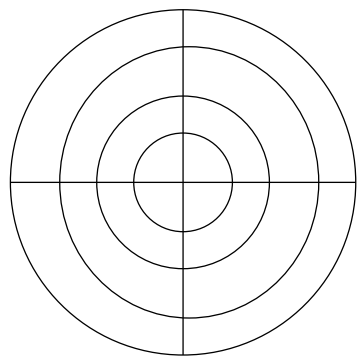

Zacílení do terče pomáhá respondentům vytvářet prioritu témat, námětů apod. $z$ jejich pohledu.

Na vedoucím pracovníkovi školy je potom, aby zvážil, co z uvedeného je možné řešit hned (je to $v$ kompetenci ředitele / ředitelky školy a bez nároků na vyšši dodatečné zdroje), co je možné řešit jen částečně a případně co není možné řešit, protože škola a její management k tomu nemají kompetence, jsou potřebné zdroje, které nejsou $\mathrm{k}$ dispozici atd.

Nezapomeňte na to, že i když to není ve vaši kompetenci (například problém legislativy nebo vysokých nároků na rozpočet), je nutné to objasnit = komunikovat cílové skupině.

POZNÁMKA: Pro získáni dílčích podnětů Ize velmi dobře využít i v práci se žáky. 


\section{REJSTŘíK}

A

Apely $129,141,142,145,162,166$

Autoevaluace 81, 95, 114, 117, 124

ATL 28, 129, 131, 132

B

Branding 101, 108, 109, 112, 173

BTL 28, 129, 131, 132

C

Celkové náklady $17,22,173$

Cena 11, 13, 16, 17, 22-24, 29, 30, 37, $97,105,112,118,142,147,173$

Copywriting 146, 161, 166

D

Distribuce 11, 16, 17, 23-25, 37, 131, 173

Dotazník 95, 97, 122-124, 171, 176, 178, 179-184, 186, 191

E

EFE a IFE matice $70,71,79$

$\mathbf{F}$

Focus Groups $171,177,178,180,184$, 186-189, 191, 213

\section{H}

Holistická koncepce marketingu 14 , 16, 35, 36

Hvězda otázek 46, 50, 51
I

Image školy $8,12,13,20,23,25,26$, $32,58,65,75,77,106,109,111$, 114-121, 123-128, 144, 169, 181

Indikátory image školy 123,124 Integrovaná marketingová komunikace $12,14,35,37,106$, 108, 109, 129, 130, 132, 144, 146, 147,173

Integrovaný marketing $13,36,164$ Interní marketing 27, 31, 33, 36 Interview 171, 184-186

K

Klima školy $20,40,68,76,77,81$, 87, 89-91, 181

Konfrontační matice 71

Komunikace 2, 3, 7-9, 11, 14, 16, 17, 19, 23-29, 31-37, 40, 42, 48, $57,63,64,66,69,78,84,87$, 88, 93-95, 97, 100-103, 106-111, $113-118,125,127-132,134,136$, 137, 141-153, 156, 163-170, 173, 177, 185, 187, 188

Komunikační kampaň $3,73,111,129$, 130, 132, 135-138, 142, 143, 145

Komunity značek $30,111,146,163-166$

Krizová komunikace 31-33, 137, 167

Kultura školy $8,13,40,42,67,68$, $76,81,82,85-100,114-116$

Kvalitativní výzkum 175-177, 187, 190, 191

Kvantitativní výzkum 175-177, 187, 191 
M

Makroprostředi 12, 61, 72, 79

Manifestace kultury školy $85,89-91$, 93, 94, 100

Marketing na internetu 9, 35, 110, $140,146-148,150,151,154-158$, 161,173

Marketing školy $1-3,6,8,9,12,14$, $15,25,26,35-37,40,44-47,69$, $73,76,77,81,101,109,114,118$, $137,144,147,148,154,157,169$, 172, 173, 178, 185

Marketingová koncepce 10, 11, 13-15, 18, 35

Marketingová komunikace $3,12,14$, $16,17,19,23-28,35,37,42$, 69, $78,93,102,106,108-111,113,114$, $127,129-132,134,143-145,147$, 149-151, 153, 156, 166, 173, 185

Marketingová komunikace na internetu 149, 150

Marketingová koncepce školy 10 , 11,15

Marketingový audit 53, 61, 64-67, 78

Marketingový informační systém $53,78,79$

Marketingový mix 11, 12, 16-18, 20, 22, 26, 31, 34-36, 69, 148

Marketingový tým 34, 37, 65, 69, 79,170

Marketingový výzkum $3,78,171,172$, 174, 187, 188, 191

Mezoprostředí 12, 205

Média 3, 12, 14, 21, 26, 28, 30, $32,33,35,36,106,111,127,129$, 131-136, 139, 142-145, 147-150, 163, 164, 166-169, 172

Měření image školy 119-121, 125, 126,128
Mikroprostředí 61, 67, 68, 73, 79

Místo a distribuce 17, 24, 173

Model hierarchie účinků 139, 140

Model značky 101, 105-107

O

Osobní prodej 26, 31, 35, 136

$\mathbf{P}$

People - lidé ve škole $12,17,33,173$

PEST analýza $12,53,65,67,68,72$, 92

Podpora prodeje 26, 29, 30, 93, 131, 144, 150

Porterova analýza / Porterův model $53,65,68,73-75,79,92,155$

Positioning $32,101,102,109,110$, $112,129,138,139,145,173$

Positioning značky $101,102,109,110$ Poslání školy $8,26,33,36,39,41$, 53-58, 64, 66, 98, 151

Produkt 11, 13, 16, 17, 19, 21-24, 28-31, 69, 102-106, 108-112, 115, 117, 131, 137-139, 153, 155, 164, 172, 189

Prvky značky 104, 113

Přímý marketing 17, 26, 35, 93, 148, 150

Public Relations 3, 14, 26, 29, 31, $32,35,36,93,114,116,132,140$, $145,150,162,167$

$\mathbf{R}$

Realizace výzkumu $174,175,177$

Reklama 13, 14, 26, 28-30, 35, 36, $106,111,130,131,133-138,141$, $143,144,147,150,152,154,161$, 164,169

Relační marketing 36,37 
S

See-Think-Do-Care 140, 151, 154

Sémantický diferenciál 119, 121, 122, 124, 125

Silná a slabá kultura organizace 95 , 96, 100

Smíšený výzkum 176, 179

Sociální média $3,26,28,30,32,35$, 106, 127, 131, 132, 136, 139, 144,

147-150, 163, 164, 166-169

Specifika služeb 19, 33, 37

Společensky zodpovědný marketing 36

Strategické plánování 2, 39-45, 49, $51,53,60,71,73,75,114$

Strategický plán školy $40,43,46$, 47, 64, 65, 126

Strategie organizace $17,41,54,70$, $84,100,154$

SWOT analýza 2, 53, 65, 67-70, 72 , $77,79,80,95,118,126,174$

\section{$\mathbf{T}$}

TTL 28, 111, 132

Typy marketingu v oblasti služeb 26,27
U

Uspokojování potřeb 9,11, 12, 14, 17,108

V

Vize školy $8,26,27,39-41,43,51$, 53-55, 57, 59-64, 98, 114, 116, 141 Vnitřní prostředí školy $59,61,68$, 76,90

VRIO $53,76,77$

Výběr médií 132, 142, 168

Vytváření sdělení 138,141

Vztahový marketing 14, 36

\section{W}

Www stránky školy $3,32,35,79$, 104, 116, 134, 146, 148-150, 155, $157,159,161,163,169,177$

$\mathbf{Z}$

Změna kultury školy $81,85,97-100$ Značka 3, 9, 12, 17, 22, 25, 35, 57, 94, 101-114, 118, 135, 137, 139, 142, 144, 145, 156, 162, 164-169, 173, 188 
Doc. PaedDr. Ludvik Eger, CSc. je docentem na Fakultě ekonomické Západočeské univerzity v Plzni. V roce 1987 absolvoval Pedagogickou fakultu v Ústí nad Labem a od roku 1991 působí na ekonomické fakultě. Kandidátskou práci (UK v Bratislavě, 1998) i habilitační práci (UKF v Nitre, 2007) zaměřil na školský management. V letech 2012-2013 byl docentem na Katedře andragogiky a personálního řizení FF UK v Praze. Aktuálně na ZČU v Plzni vyučuje předměty Trénink obchodního jednáni a Marketing na internetu na bakalářském stupni studia a Komerční komunikace a Výzkum trhu na navazujícím magisterském stupni studia, na doktorském studiu předmět Metodologie vědy. Na Fakultě pedagogické ZČU v Plzni garantuje a vyučuje předmět Školský management.

Od roku 1996 byl na ZČU v Plzni garantem kurzu Management a ekonomika školy, který byl pod MŠMT akreditován jako tzv. FS II pro vedoucí pedagogické pracovníky. Spolupracoval v dílčich aktivitách a projektech s Českou manažerskou asociaci a s NiDV. V projektech TEMPUS, Comenius, Arion, Leonardo a pod CEDEFOP se účastnil kratšich stáži v zaměřeni na management škol v Anglii, Belgii, Španělsku, Mad'arsku, Polsku, Rakousku, Itálii, Sasku, a velmi úzce spolupracuje řadu let $s$ experty ze Slovenska. Má mezinárodni profesni marketingovou certifikaci CIMA B.

$\checkmark$ roce 2001 byl s podporou projektu Comenius autorem prvního e-learningového kurzu pro management škol v ČR. Výstupy výzkumných studii a publikační činnosti jeho a spoluautorů v indexovaných časopisech ve Web of Science a Scopus jsou zaměřené na vzděláváni vedoucich pracovníků škol, řizení vzdělávacích projektů, image a kulturu školy, využití komunikace na Facebooku fakultami a univerzitami a využití ICT ve vzdělávání dospělých. Od roku 2011 je řešitelem a spoluřešitelem několika mezinárodnich projektů Visegrad Fund zaměřených na diversity management, talent management, vzdělávání k podnikatelství a komunikaci lidí na sociálních médiích. 